\title{
APLICABILIDADE DO ANTÍGENO TETÂNICO CONJUGADO COM DERIVADOS DO MONOMETOXI-POLIETILENOGLICOL
}

\section{SALLY MÜLLER AFFONSO PRADO}

Tese (Doutorado) apresentada ao Programa de Pós-Graduação Interunidades em Biotecnologia USP/Instituto Butantan/IPT, para obtenção do Título de Doutor em Biotecnologia.

\section{SÃO PAULO}




\section{APLICABILIDADE DO ANTÍGENO TETÂNICO CONJUGADO COM DERIVADOS DO MONOMETOXI-POLIETILENOGLICOL}

\section{SALLY MÜLLER AFFONSO PRADO}

Tese (Doutorado) apresentada ao Programa de Pós-Graduação Interunidades em Biotecnologia USP/Instituto Butantan/IPT, para obtenção do Título de Doutor em Biotecnologia.

Área de Concentração: Biotecnologia

Orientador: Dr. José Abrahão Neto Co-orientador: Dr. Rosalvo Guidolin

\section{SÃO PAULO}


DADOS DE CATALOGAÇÃO NA PUBLICAÇÃO (CIP)

Serviço de Biblioteca e Informação Biomédica do Instituto de Ciências Biomédicas da Universidade de São Paulo

(c) reprodução total

Prado, Sally Müller Affonso.

Aplicabilidade do Antígeno Tetânico Conjugado com Derivados do Monometoxi-polietilenoglicol / Sally Müller Affonso Prado. -- São Paulo, 2008.

Orientador: José Abrahão Neto.

Tese (Doutorado) - Universidade de São Paulo. Instituto de Ciências Biomédicas. Programa de Pós-Graduação Interunidades em Biotecnologia USP/IPT/Instituto Butantan. Área de concentração: Biotecnologia. Linha de pesquisa: Vacinas e Soros.

Versão do título para o inglês: Applicability of Tetanus Antigen Conjugated to Derivatives of Monometoxypolyethylene glycol.

Descritores: 1. PEG 2. mPEG 3. Peglação 4. Toxinas 5. Adjuvantes Imunológicos 6. Antígenos I. Abrahão-Neto, José II. Universidade de São Paulo. Instituto de Ciências Biomédicas. Programa de Pós Graduação em Biotecnologia III. Título. 


\section{UNIVERSIDADE DE SÃO PAULO}

Programa de Pós-Graduação Interunidades em Biotecnologia

Universidade de São Paulo, Instituto Butantan, Instituto de Pesquisas Tecnológicas

Candidato(a): $\quad$ Sally Müller Affonso Prado.

Título da Tese: $\quad$ Aplicabilidade do antígeno tetânico conjugado com derivados do Monometoxi-polietilenoglicol.

Orientador(a): $\quad$ José Abrahão Neto.

A Comissão Julgadora dos trabalhos de Defesa da Tese de Doutorado, em sessão pública realizada a I................., considerou

\section{( ) Aprovado(a) ( ) Reprovado(a)}

\begin{tabular}{|c|c|}
\hline Examinador(a): & $\begin{array}{l}\text { Assinatura: } \\
\text { Nome: ....... } \\
\text { Instituição: }\end{array}$ \\
\hline Examinador(a): & $\begin{array}{l}\text { Assinatura: } \\
\text { Nome: ........ } \\
\text { Instituição: }\end{array}$ \\
\hline Examinador(a): & $\begin{array}{l}\text { Assinatura: } \\
\text { Nome: ........ } \\
\text { Instituição: }\end{array}$ \\
\hline Examinador(a): & $\begin{array}{l}\text { Assinatura: } \\
\text { Nome: ........ } \\
\text { Instituição: }\end{array}$ \\
\hline Presidente: & $\begin{array}{l}\text { Assinatura: } \\
\text { Nome: ....... } \\
\text { Instituição: }\end{array}$ \\
\hline
\end{tabular}


Dedico

A meus pais, Domingos e Maryse.

\section{Ofereço}

A meu esposo, José.

À minha filha, Camila.

\section{Agradeço}

A Deus, por cuidar do meu coração e da minha vida. 


\section{AGRADECIMENTOS}

- Ao Instituto Butantan e ao Departamento de Tecnologia Bioquímico-Farmacêutica da Faculdade de Ciências Farmacêuticas da Universidade de São Paulo, por possibilitarem a execução do trabalho conjunto.

- Ao Prof. Dr. José Abrahão Neto, pela orientação desta Tese e pelos ensinamentos quanto à conjugação do antígeno tetânico ao monometoxi-polietilenoglicol.

- Ao Dr. Rosalvo Guidolin, pela co-orientação, especialmente quanto aos esquemas de imunização empregados e pela revisão do trabalho.

- À Dra. Hisako Gondo Higashi, Diretora da Divisão de Desenvolvimento Tecnológico e Produção do Instituto Butantan, pelo incentivo e carinho sempre dedicado.

- Ao Prof. Dr. Osvaldo Augusto Brazil Esteves Sant'Anna, pelas lições e colaboração na revisão deste trabalho. Valoroso pesquisador e, sobretudo, um grande amigo.

- À Fabiana Belasco Guilhen Olivier, pelo auxílio e sugestões na execução dos experimentos.

- Ao Alex Araújo Simões, pela participação na parte prática e auxílio quanto aos esquemas gráficos desta Tese.

- Ao José Roberto Marcelino e equipe do Serviço de Imunologia da Divisão de Desenvolvimento Tecnológico e Produção do Instituto Butantan, pela execução prática dos esquemas de imunização em eqüinos na Fazenda São Joaquim.

- À Sabrina Almeida de Marchi, Ana Cláudia Yone Antunes de Souza Takahashi e Renata de Arruda Matarazzo, pela colaboração nos ensaios in vitro.

- À Josefina Farina Moraes e funcionários da Seção de Controle Biológico do Instituto Butantan, pela colaboração nos doseamentos in vivo.

- Às equipes da Central de Purificação de Produtos Bacterianos e da Seção de Vacinas Anaeróbicas do Serviço de Bacteriologia da Divisão de Desenvolvimento Tecnológico e Produção do Instituto Butantan, pela colaboração e especial atenção dedicada.

- À Camila Affonso Prado, pelo auxílio na digitação e conferência final do texto.

- À Maria Aparecida Sakauchi, pela colaboração durante a elaboração desta Tese. 
- Às funcionárias do Serviço de Biblioteca e Informação Biomédica do Instituto de Ciências Biomédicas da Universidade de São Paulo, pela revisão das referências bibliográficas e demais orientações quanto aos aspectos formais desta Tese.

- Aos funcionários da secretaria da Pós-Graduação em Biotecnologia USP/Instituto Butantan/IPT, pelos esclarecimentos burocráticos.

- À Fundação Butantan, pelo apoio financeiro.

- Aos que involuntariamente foram omitidos nestes agradecimentos, as mais sinceras desculpas justificadas pelo grande número de amigos que, direta ou indiretamente, contribuíram para a realização deste trabalho. 
"Não tenho orgulho de minha pobre ciência. Mas estou contente com minha alma e meu coração".

Vital Brazil 


\section{RESUMO}

PRADO, S. M. A. Aplicabilidade do Antígeno Tetânico Conjugado com Derivados do Monometoxi-polietilenoglicol. 2008. 143 f. Tese (Doutorado em Biotecnologia) - Instituto de Ciências Biomédicas, Universidade de São Paulo, São Paulo, 2008.

Os esquemas de imunização de eqüinos para produção de soro antitetânico são baseados em inoculações que estimulem o sistema imunológico para obtenção de títulos elevados de anticorpos específicos. As principais dificuldades encontradas durante tal produção ocorrem em razão dos antígenos possuírem baixa imunogenicidade e/ou atividade tóxica que pode provocar reação local ou sistêmica. Dessa forma, esse estudo objetivou analisar o monometoxi-polietilenoglicol succinimidil ácido propiônico (mPEG-SPA) como adjuvante e inibidor da atividade neurotóxica da toxina tetânica, pois esse polímero é inerte, atóxico e não imunogênico. Analisou-se o mPEG-SPA de 5 e 20 kDa conjugado à toxina tetânica adsorvida ou não pelo gel de $\mathrm{Al}(\mathrm{OH})_{3}$. O grau de peglação foi determinado por colorimetria, utilizando-se a técnica do ácido trinitrobenzeno sulfônico (TNBS). A toxicidade das amostras foi avaliada pelas determinações de $\mathrm{DL}_{50}$, revelando que a conjugação da toxina tetânica com mPEG-SPA 5.000 e 20.000 inibiu a atividade neurotóxica da toxina tetânica adsorvida ou não pelo gel de $\mathrm{Al}(\mathrm{OH})_{3}$. Avaliou-se a influência da via de inoculação, subcutânea e intramuscular, e se verificou que a via subcutânea foi mais efetiva na indução de resposta à toxina tetânica tratada pelo mPEG-SPA, enquanto o efeito adjuvante do gel de $\mathrm{Al}(\mathrm{OH})_{3}$ foi evidenciado pela aplicação por via intramuscular. Trinta cavalos foram submetidos a um esquema de imunização seletiva, selecionando-se dezoito animais e dividindo-os em grupos distintos para a imunização com os antígenos: toxina tetânica conjugada ao mPEG-SPA 5.000 e mPEG-SPA 5.000(2X); e toxina tetânica adsorvida ou não pelo gel de $\mathrm{Al}(\mathrm{OH})_{3}$. Os soros dos cavalos imunizados foram individualmente testados quanto à concentração de anticorpos antitetânicos através do ensaio ToBI Teste, cujos resultados permitiram verificar a evolução da resposta imune no decorreer das imunizações. Esses soros também foram avaliados através dos métodos de imunodifusão, eletroforese e immunoblotting, tendo o último indicado, nas condições do estudo, uma provável superioridade antigênica da Toxina Tetânica Fluida relativamente aos adjuvantes empregados. A conjugação mPEG-SPA comprovou ser efetiva na produção do soro antitetânico terapêutico para uso humano.

Palavras-chave: PEG. mPEG. Peglação. Toxinas. Adjuvantes Imunológicos. Antígenos. 


\begin{abstract}
PRADO, S. M. A. Applicability of Tetanus Antigen Conjugated to Derivatives of Monometoxypolyethylene Glycol. 143 f. Ph. D. Thesis (Biotechnology) - Instituto de Ciências Biomédicas da Universidade de São Paulo, São Paulo, 2008.

The schemes of equines immunization to obtain anti-tetanus serum are based on inoculations that stimulate the immunological system in order to achieve high specific antibodies titles. The main difficulties of such production are due to the low antigen immunogenicity and/or to the toxic activity that may lead to local or systemic reactions. The purpose of this study was to evaluate the monometoxypolyethylene glycol succinimidyl propionic acid (SPA-mPEG) as adjuvant and inhibitor of tetanus toxin neurotoxic activity, since this polymer is inert, nontoxic and non-immunogenic. It was analyzed the SPA-mPEG 5 and $20 \mathrm{kDa}$ conjugated to tetanus toxin adsorbed or not by $\mathrm{Al}(\mathrm{OH})_{3}$ gel. The pegylation degree was determined by colorimetry, by using the technique of trinitrobenzenesulfonic acid (TNBS). The samples toxicity was evaluated by the $\mathrm{DL}_{50}$ determination, disclosing that the conjugation of tetanus toxin to SPA-mPEG 5,000 and 20,000 inhibited the neurotoxic activity of the toxin adsorbed or not by $\mathrm{Al}(\mathrm{OH})_{3}$ gel. It was evaluated the influence of the subcutaneous and intramuscular inoculation route and it was observed that the former was more effective in induction of response to the toxin treated with SPA-mPEG, while the adjuvant effect of $\mathrm{Al}(\mathrm{OH})_{3}$ gel was evidenced by the intramuscular method of application. Thirty horses were submitted to a selective scheme of immunization and it was chosen eighteen animals which were divided into different groups to be immunized with the antigens: tetanus toxin conjugated to SPA-mPEG 5,000 and SPA-mPEG 5,000(2X); and tetanus toxin adsorbed or not by $\mathrm{Al}(\mathrm{OH})_{3}$ gel. The immunized horses sera were individually tested as for the concentration of antitetanus antibodies through the ToBI Test assay and the results obtained enabled the evaluation of the immune response development during the immunizations. These sera were also analyzed through the methods of immunodiffusion, electrophoresis and immunoblotting, and the last one is indicative, under the conditions of this study, a probable antigenic superiority of Fluid Tetanus Toxin relatively to the adjuvants used. The SPA-mPEG conjugation proved to be effective for anti-tetanus human therapeutic serum production.
\end{abstract}

Key words: PEG. mPEG. Pegylation. Toxins. Immunologics Adjuvants. Antigens. 


\section{LISTA DE FIGURAS}

Figura 1: Clostridium tetani

Figura 2: Estrutura da toxina tetânica, demonstrando o domínio estrutural principal e suas funções e mecanismo de ação da toxina

Figura 3: Seqüência primária e secundária da cadeia leve (L) com 449 resíduos de aminoácidos

Figura 4: Seqüência primária e secundária da cadeia (A) polipeptídica da TeNT com 1.315 resíduos de aminoácidos

Figura 5: Seqüência primária e secundária da cadeia (B) polipeptídica da TeNT com 1.315 resíduos de aminoácidos

Figura 6: Organização similar entre a estrutura da neurotoxina tetânica e neurotoxina botulínica tipo A

Figura 7: Diagrama da estrutura do domínio das neurotoxinas clostridiais

Figura 8: Ligação e endocitose da toxina tetânica via múltiplos receptores da membrana

Figura 9: Neurônio motor de mamífero e interação de interneurônio inibitório da coluna espinhal

Figura 10: Mecanismo de ação da toxina tetânica

Figura 11: Representação da reação promovida pelo formaldeído em grupos amina

Figura 12: Resultado final do tratamento da toxina tetânica pelo formaldeído

Figura 13: Status acerca da eliminação por países do tétano neonatal e maternal .......

Figura 14: Derivados do polietilenoglicol (PEG)

Figura 15: Representação estrutural da proteína conjugada ao PEG linear ou ramificado 
Figura 16: ToBI TESTE (Toxin Inhibition Test) - esquema ilustrativo

Figura 17: Imunodifusão

Figura 18: Correlação (r) entre os valores de concentração cujos dados estão apresentados na Tabela 12

Figura 19: Eletroforese em gel de acrilamida (SDS-PAGE) em concentração de 10\% de acrilamida e coloração com Coomassie Blue 250 R. Amostras de toxina tetânica tratadas com 2-mercaptoetanol

Figura 20: $\mathrm{DL}_{50}$ das amostras de TxT conjugadas ao mPEG-SPA 5.000

Figura 21: $\mathrm{DL}_{50}$ das amostras de TxT conjugadas ao mPEG-SPA 5.000(2X)

Figura 22: $\quad \mathrm{DL}_{50}$ das amostras de TxT conjugadas ao mPEG-SPA 20.000

Figura 23: $\quad \mathrm{DL}_{50}$ das amostras de TxT conjugadas ao mPEG-SPA 20.000(2X)

Figura 24: Distribuição de freqüência dos títulos de anticorpos anti-TxT, 28 dias após reforço vacinal

Figura 25: Distribuição de freqüência dos títulos de anticorpos anti-TxT, 27 dias após a segunda dose

Figura 26: Cinética de produção de anticorpos anti-TxT em animais imunizados segundo diferentes protocolos

Figura 27: Títulos médios de anticorpos anti-TxT

Figura 28: Valores médios de anticorpos anti-TxT obtidos ao término da primeira reimunização

Figura 29: Valores médios de anticorpos anti-TxT obtidos ao término da segunda reimunização

Figura 30: Imunodifusão 
Figura 31: Eletroforese em gel de acrilamida (SDS-PAGE) em concentração de 7,5\% de acrilamida, coloração com Coomassie Blue 250 R. Amostras de soros de cavalos não tratadas com 2-mercaptoetanol aplicadas com uma concentração de proteínas de $0,7 \mathrm{mg} / \mathrm{mL}$

Figura 32: Eletroforese em gel de acrilamida (SDS-PAGE) em concentração de 7,5\% de acrilamida, coloração com Coomassie Blue 250 R. Amostras de soros de cavalos não tratadas com 2-mercaptoetanol aplicadas com uma concentração de proteínas de $0,7 \mathrm{mg} / \mathrm{mL}$

Figura 33: Membrana de Immunoblotting. Gel de acrilamida em concentração de 7,5\% de acrilamida, coloração com Coomassie Blue 250 R. Toxina tetânica não tratada com 2-mercaptoetanol

Figura 34: Membrana de Immunoblotting. Gel de acrilamida em concentração de $7,5 \%$ de acrilamida, coloração com Coomassie Blue 250 R. Toxina tetânica tratada com 2-mercaptoteanol

Figura 35: Membrana de Immunoblotting. Gel de acrilamida em concentração de 7,5\% de acrilamida, coloração com Coomassie Blue 250 R. Toxina tetânica não tratada com 2-mercaptoetanol

Figura 36: Membrana de Immunoblotting. Gel de acrilamida em concentração de $7,5 \%$ de acrilamida, coloração com Coomassie Blue 250 R. Toxina tetânica tratada com 2-mercaptoetanol 


\section{LISTA DE TABELAS}

Tabela 1: Casos confirmados de tétano (exceto o neonatal), por ano, segundo regiões do Brasil, 1990 a 2005

Tabela 2: Casos confirmados de tétano neonatal, por ano, segundo região do Brasil, 1990 a 2005

Tabela 3: Profilaxia do tétano após ferimento

Tabela 4: $\quad$ Concentração $(\mathrm{mg})$ de mPEG-SPA frente a $1 \mathrm{mg}$ de Toxina Tetânica Purificada

Tabela 5: $\quad$ Esquema de imunização em cobaias e vias utilizadas

Tabela 6: Grupos de cavalos e antígenos empregados nos esquemas de hiperimunização

Tabela 7: $\quad$ Esquema de hiperimunização e antígenos empregados

Tabela 8: Grupos e subgrupos de cavalos e antígenos empregados nos esquemas de hiperimunização

Tabela 9: Esquema de primeira reimunização e antígenos empregados

Tabela 10: Segundo esquema de reimunização e antígenos empregados 98

Tabela 11: Valores comparativos determinados através de testes físico-químicos e biológico para a Toxina Tetânica Concentrada e Toxina Tetânica Purificada

Tabela 12: Valores de absorbância (em 435 nm) da Toxina Tetânica Purificada

Tabela 13: Grau de sítios de amina conjugada ao mPEG-SPA 5.000 e mPEG-SPA 20.000

Tabela 14: Características físico-químicas e biológica da Anatoxina Tetânica Produto Acabado a Granel e do Toxóide Tetânico

Tabela 15: Características físico-químicas e biológica da TxT 
Tabela 16: Títulos de anticorpos anti-TxT e vias de inoculação

Tabela 17: $\quad \mathrm{DL}_{50}$ das TxTmPEG-SPA

Tabela 18: Características das TxT conjugadas ao mPEG-SPA e adsorvidas em gel de $\mathrm{Al}(\mathrm{OH})_{3}$

Tabela 19: Títulos individuais de eqüinos no tempo zero e após a imunização de base

Tabela 20: Títulos individuais de eqüinos no tempo zero e após a segunda dose vacinal

Tabela 21: Descrição dos grupos de cavalos destinados à imunização e títulos iniciais de anticorpos anti-TxT

Tabela 22: Perfil dos subgrupos de cavalos destinados à reimunização

Tabela 23: Títulos de anticorpos anti-TxT obtidos nos esquemas de primeira reimunização

Tabela 24: Títulos de anticorpos anti-TXT obtidos no esquema de segunda reimunização 


\section{LISTA DE ABREVIATURAS E SIGLAS}

\begin{tabular}{|c|c|}
\hline ABREVIATURA & DESCRIÇÃO \\
\hline $\mathrm{ADA}$ & Adenosina deaminase \\
\hline ADS & “Antigen delivery system" \\
\hline AIDS & Síndrome da imunodeficiência adquirida \\
\hline APR & "Array of presynaptic receptors" \\
\hline BCIP & "5-bromo-4-chloro-3-indolyl phosphate" \\
\hline BoNT/A & Neurotoxina botulínica tipo A \\
\hline BoNTs & Neurotoxinas botulínicas \\
\hline BSA & Albumina bovina \\
\hline CTL & Linfócitos $\mathrm{T}$ citotóxicos \\
\hline $\mathrm{DL}_{50}$ & Dose letal $50 \%$ \\
\hline $\mathrm{dT}$ & Vacina Dupla para uso adulto \\
\hline DT & Vacina Dupla para uso infantil \\
\hline DTP & Vacina Tríplice \\
\hline $\mathrm{DTP}+\mathrm{Hib}$ & Vacina Tríplice + Haemophilus influenzae Tipo B \\
\hline EDTA & Ácido etilenodiamino tetra-acético \\
\hline EPI & "Expanded Programme on Immunization" \\
\hline $\mathrm{Fc}$ & Fragmento $\mathrm{C}$ \\
\hline FCA & Adjuvante completo de Freund \\
\hline FDA & "U. S. Food and Drug Administration" \\
\hline FIA & Adjuvante incompleto de Freund \\
\hline FUNASA & Fundação Nacional de Saúde \\
\hline GAVI & Fundo Internacional de Finanças para Imunização \\
\hline GM-CSF & Citoxina - fator estimulador de colônia de granulócitos e macrófago \\
\hline GPI & "Glycophosphoinositol" \\
\hline $\mathrm{H}$ & Cadeia pesada \\
\hline $\mathrm{H}_{\mathrm{C}}$ & Carboxi terminal \\
\hline HIV & "Human imunodeficiency virus" \\
\hline $\mathrm{H}_{\mathrm{N}}$ & Amino terminal \\
\hline HPLC & Cromatografia de alta "performance" \\
\hline IB & Instituto Butantan \\
\hline IFN- $\alpha$ & Interferon alfa \\
\hline $\operatorname{IgE}$ & Imunoglobulina $\mathrm{E}$ \\
\hline $\operatorname{IgG}$ & Imunoglobulina $\mathrm{G}$ \\
\hline IL-12 & Interleucina 12 \\
\hline INCQS & Instituto Nacional de Controle de Qualidade em Saúde \\
\hline ISCOMs & "Immune stimulatory complexes" \\
\hline ISP & "Instituto Nacional de Salud Publica de Chile" \\
\hline $\mathrm{Kf}$ & Velocidade de floculação \\
\hline $\mathrm{L}$ & Cadeia leve \\
\hline $\mathrm{L}+$ & Dose Limite Morte \\
\hline Lf & Limite floculante \\
\hline LPS & Lipopolissacarídeo \\
\hline MALDI & Espectrofotometria de massa \\
\hline MDP & Muramilpeptídeo \\
\hline mPEG & Monometoxi-polietilenoglicol \\
\hline mPEG-SPA & Monometoxi-polietilenoglicol succinimidil ácido propiônico \\
\hline
\end{tabular}




\begin{tabular}{|c|c|}
\hline ABREVIATURA & DESCRIÇÃO \\
\hline NBT & "Nitroblue tetrazolium" \\
\hline NHS & N-hidroxisuccinimidil \\
\hline NIBSC & "National Institute for Biological Standards and Control" \\
\hline NOD2 & Gene de suscetibilidade \\
\hline OPAS & Organização Pan-Americana da Saúde \\
\hline OPD & "o-Phenylenediamine" \\
\hline PBS & Tampão fosfato-salina \\
\hline PBS-T80 & Tampão fosfato-salina com Tween 80 \\
\hline PEG & Polietilenoglicol \\
\hline $\mathrm{PEG}_{1}$ & [2-(O-metoxipolietilenoglicol)-6-cloro-s-triazina] \\
\hline $\mathrm{PEG}_{2}$ & [2,4-bis(O-metoxipolietilenoglicol)-6-cloro-s-triazina] \\
\hline PEG-ADA & Enzima adenosina deaminase \\
\hline PNI & Programa Nacional de Imunizações \\
\hline PVDF & "Polivinyletilene difluride" \\
\hline QS21 & Quillaja saponaria fração 21 \\
\hline QuilA & Extrato solúvel da árvore Quillaja saponaria \\
\hline RCSB & "Research Collaboratory for Structural Bioinformatics" \\
\hline RIPSA & Rede Integrada de Informações para a Saúde \\
\hline SAT & Soro antitetânico \\
\hline SDS & Dodecil sulfato de sódio \\
\hline SDS-PAGE & Eletroforese em gel de poliacrilamida \\
\hline SINAN & Sistema de Informação de Agravos de Notificação \\
\hline SLPs & "Array of surface-layer proteins" \\
\hline SNARE & "Soluble NSF attachment protein receptor" \\
\hline SOD & Superóxido dismutase \\
\hline SSID & Síndrome da imunodeficiência aguda \\
\hline $\mathrm{T} \mathrm{CD}^{+}$ & Receptor 4 de linfócitos $\mathrm{T}$ auxiliar \\
\hline $\mathrm{T} \mathrm{CD}^{+}$ & Receptor de linfócito T citotóxico \\
\hline TeNT & Neurotoxina tetânica \\
\hline $\mathrm{T}_{\mathrm{H}} 1$ & Células T auxiliar 1 \\
\hline TLR-2 & Receptor 2 (semelhante ao Toll) \\
\hline TLR-4 & Receptor 4 (semelhante ao Toll) \\
\hline TLR-9 & Receptor 9 (semelhante ao Toll) \\
\hline TLRS & Receptores semelhantes ao Toll \\
\hline TNBS & Ácido trinitrobenzeno sulfúrico \\
\hline ToBI Teste & "Toxin Inhibition Test" \\
\hline $\mathrm{TT}$ & Toxóide Tetânico \\
\hline $\mathrm{TxT}$ & Toxina tetânica \\
\hline TxTmPEG-SPA & $\begin{array}{l}\text { Toxina tetânica congugada ao monometoxi-polietilenoglicol } \\
\text { succinimidil ácido propiônico }\end{array}$ \\
\hline UI & Unidade internacional \\
\hline UNFA & "United Nations Population Fund" \\
\hline UNICEF & "United Nations Children's Fund" \\
\hline UOp & Unidade opacimétrica \\
\hline USD \$ & Dólares americanos \\
\hline UTI & Unidade de tratamento intensivo \\
\hline VAMP & "Vesicle associated membrane protein" \\
\hline WHO & "World Health Organization" \\
\hline
\end{tabular}




\section{SUMÁRIO}

1 INTRODUÇÃ

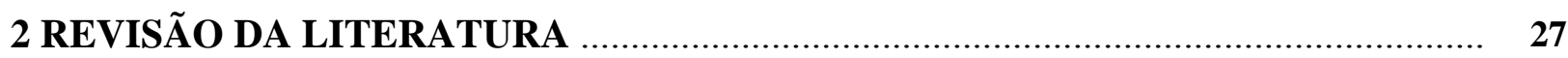

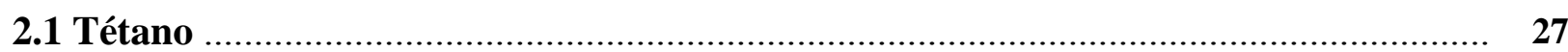

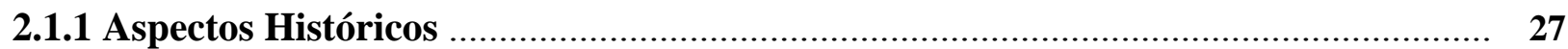

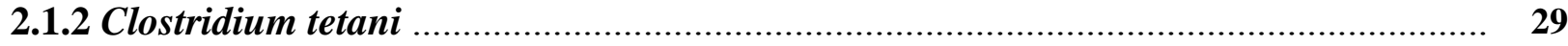

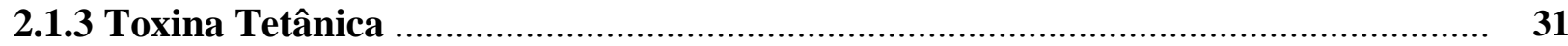

2.1.3.1 O Processo de Destoxificação da Toxina Tetânica ............................................

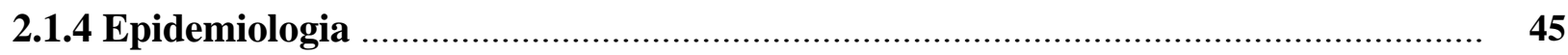

2.1.5 Manifestações Clínicas .................................................................................... $\quad 50$

2.1.6 Prevenção, Profilaxia e Tratamento …................................................................... 51

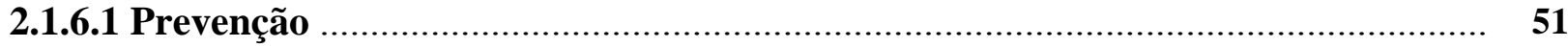

2.1.6.2 Profilaxia do Tétano após Ferimento ….......................................................... 52

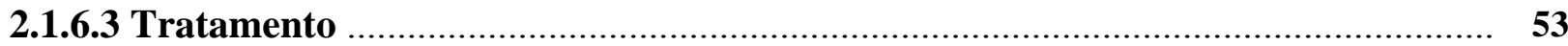

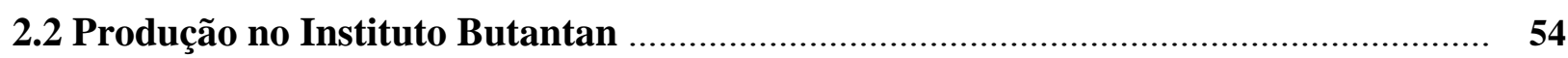

2.2.1 Produção da Anatoxina Tetânica ..................................................................... 54

2.2.2 Produção do Soro Antitetânico ….......................................................................... 55

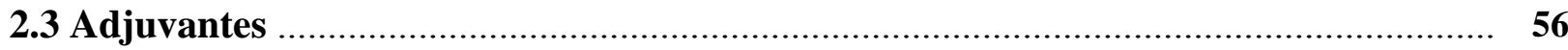

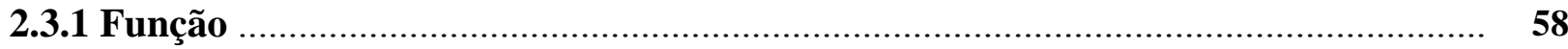

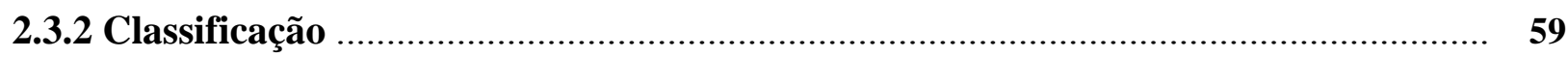

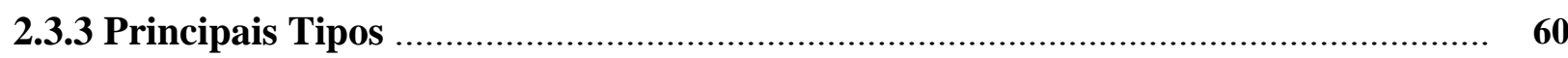

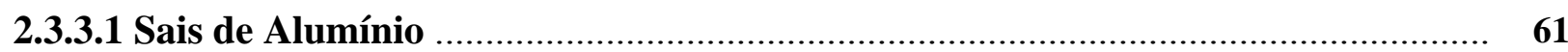

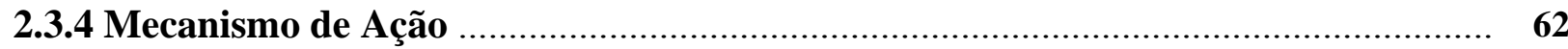

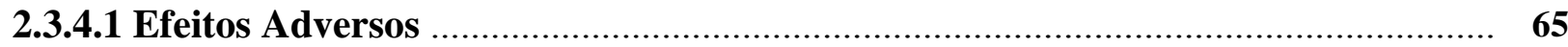

2.4 Monometoxi-polietilenoglicol (mPEG) ............................................................... 66

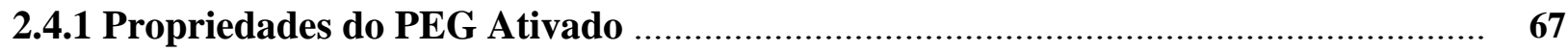

2.4.2 Ativação do PEG para Uso na Conjugação de Proteínas ...................................... 69

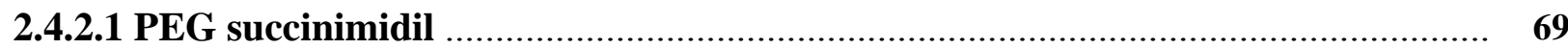

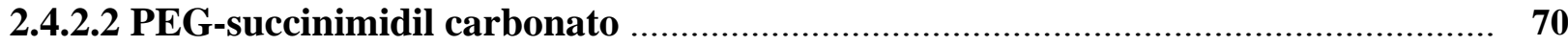

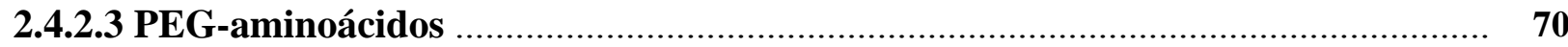

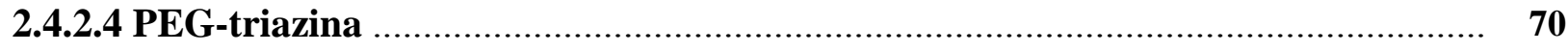

2.4.2.5 PEG-multivalente em Forma de Pente Achatado ............................................ 70

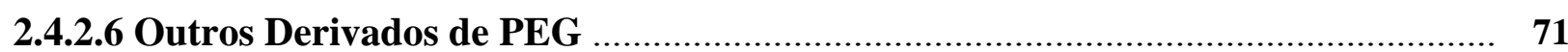

2.4.3 Parâmetros para Reação de PEGlação ........................................................... 71

2.4.4 Caracterização do mPEG Conjugado …......................................................... 72

2.4.5 Aplicações Médicas das Proteínas Modificadas pelo PEG …................................... 73 
2.4.6 Imunoreatividade das Proteínas Modificadas pelo PEG …................................ 74

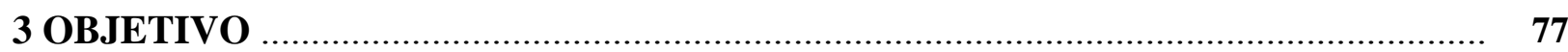

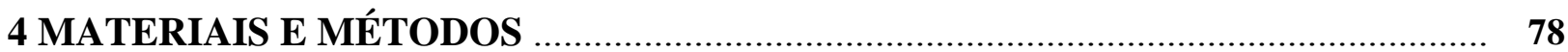

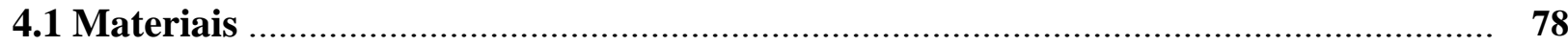

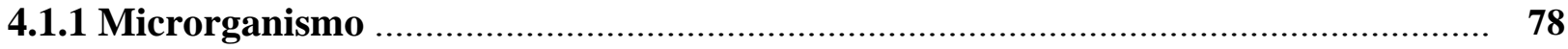

4.1.2 Obtenção da Toxina Tetânica .......................................................................... 78

4.1.3 Purificação da Toxina Tetânica Concentrada ....................................................... $\quad 78$

4.1.4 Destoxificação da Toxina Tetânica Concentrada …................................................. $\quad 79$

4.1.5 Purificação da Anatoxina Tetânica a Granel ........................................................ 79

4.1.6 Preparação do Toxóide Tetânico (TT) .......................................................................

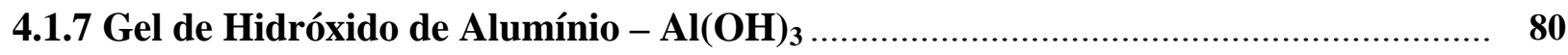

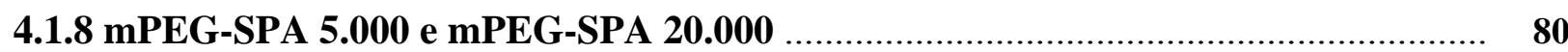

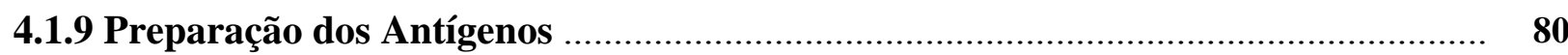

4.1.9.1 Toxina Tetânica Fluida e Toxina Tetânica Fluida e Adsorvida pelo Gel $\mathrm{Al}(\mathrm{OH})_{3}$

4.1.9.2 Conjugação da Toxina Tetânica com mPEG-SPA ….......................................... 80

4.1.9.3 Toxina Tetânica Conjugada com mPEG-SPA e Adsorvida pelo Gel de $\mathrm{Al}(\mathrm{OH})_{3} \quad 82$

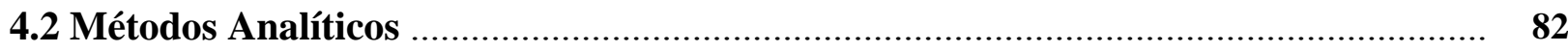

4.2.1 Monitoramento do Grau de PEGlação da Toxina Tetânica .................................. 82

4.2.2 Determinação do Limite de Floculação ............................................................ 83

4.2.3 Determinação do Nitrogênio Protéico ................................................................. 83

4.2.4 Determinação da Pureza Antigênica …................................................................ 83

4.2.5 Determinação da Concentração de Proteínas ....................................................... 83

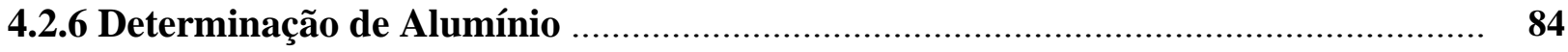

4.2.7 Determinação do Teor de Sulfato de Amônio ........................................................ 84

4.2.8 Determinação de Timerosal ........................................................................ 84

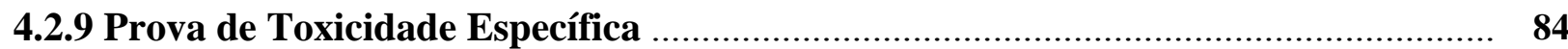

4.2.10 Determinação da Atividade Imunogênica (determinação do título antitóxico em

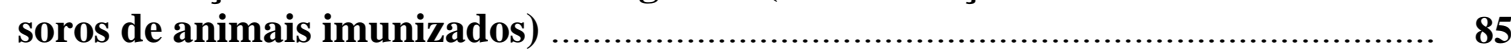

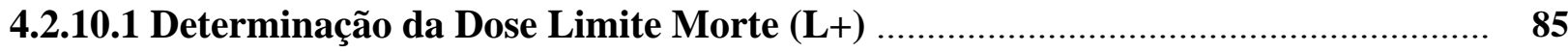

4.2.10.2 Titulação da Antitoxina Tetânica .................................................................. 85

4.2.11 Determinação da DL $_{50}($ Dose Letal 50\%) ........................................................... 86

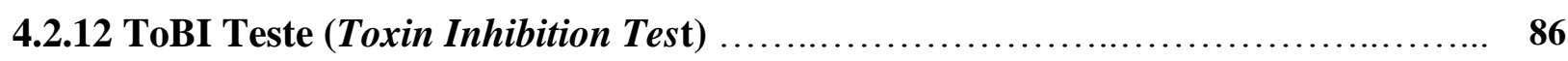

4.2.13 Imunodifusão (Técnica de Ouchterlony) ....................................................... 87

4.2.14 Eletroforese em Gel de Poliacrilamida (SDS-PAGE) ....................................... 89

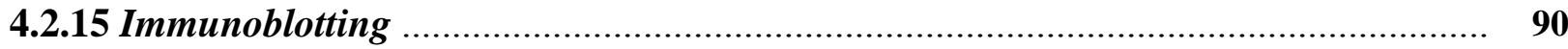

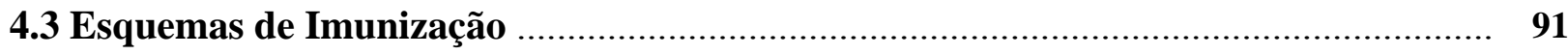

4.3.1 Imunização das Cobaias - Estudo da Via de Inoculação .................................... 91 


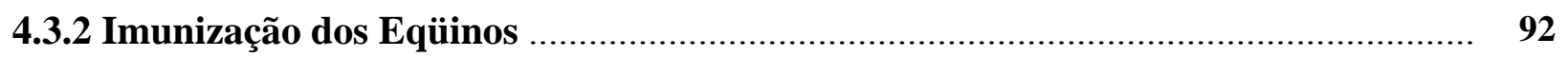

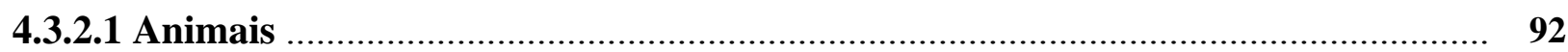

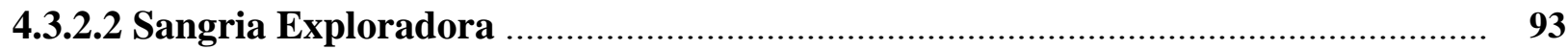

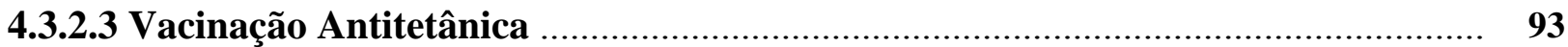

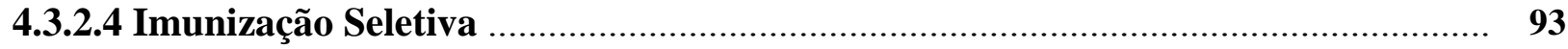

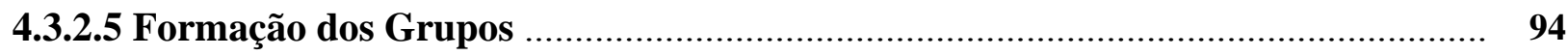

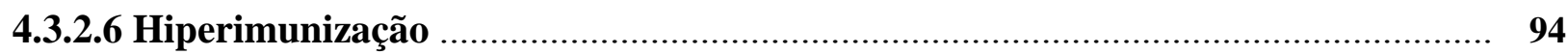

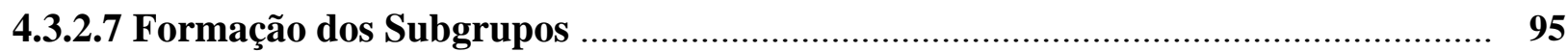

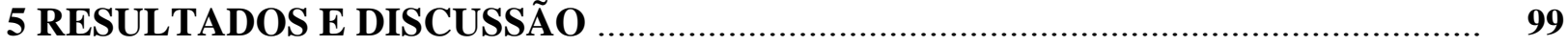

5.1 Grau de PEGlação da Toxina Tetânica Modificada pelo mPEG-SPA ….................... 100

5.2 Estudo Comparativo da Via de Inoculação .......................................................... 104

5.3 Caracterização dos Antígenos Conjugados ao mPEG-SPA .................................... 106

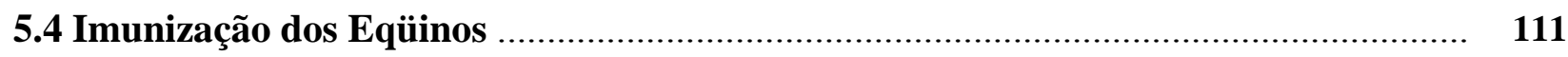

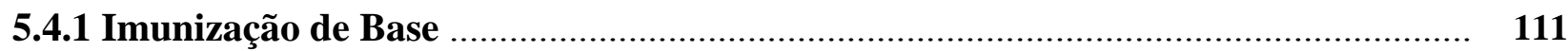

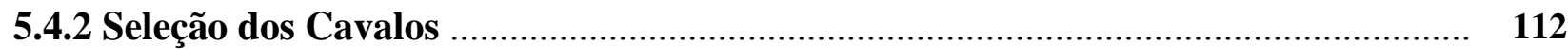

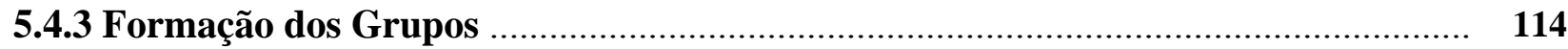

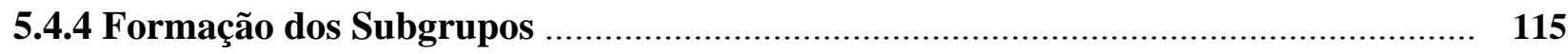

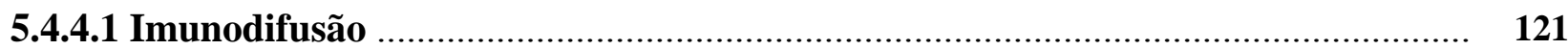

5.4.4.2 Identificação de Imunoglobulina Através de Eletroforese em Gel de

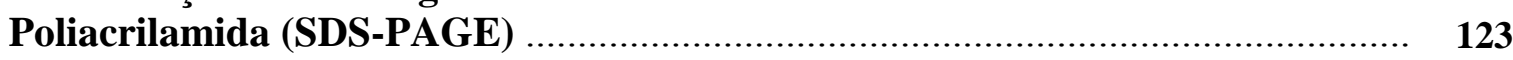

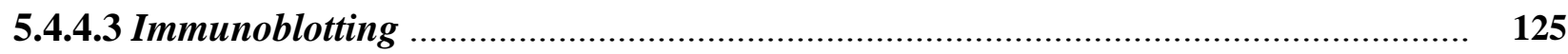

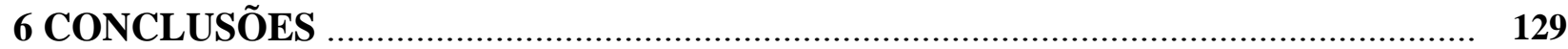

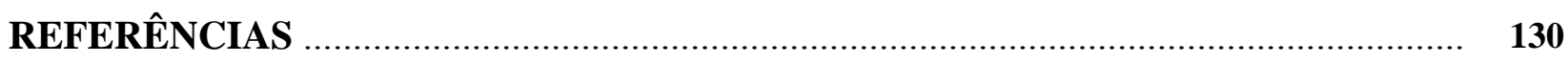




\section{INTRODUÇÃO}

O Clostridium tetani, agente etiológico do tétano, é uma doença infecciosa e não contagiosa cujos sinais clínicos se cacterizam por contraturas musculares. O processo infeccioso ocorre devido à contaminação de feridas pelos esporos que, ao se estabelecerem nos tecidos, proliferam-se formando bacilos secretores de exotoxina potente que age sobre as células motoras do sistema nervoso (BIER, 1978a; MURRAY et al., 2000). Os esporos são encontrados nos mais variados ambientes, como em solos tratados com estrume e nas fezes de eqüinos, bovinos, ovinos, roedores e animais domésticos, sendo que em comunidades agrícolas um número significante de adultos pode abrigar o microrganismo. Em usuários de drogas intravenosas a infecção pode ocorrer por esporos localizados na superfície da pele e também na heroína contaminada (MALLICK e WINSLET, 2004).

O período de incubação do tétano varia de poucos dias a algumas semanas e está diretamente relacionado à distância entre a infecção primária da ferida e o sistema nervoso central. Esta infecção caracteriza-se pela hipertonia da musculatura estriada, generalizada ou não (MURRAY et al., 2000).

As manifestações clínicas do tétano no adulto podem ser de três tipos: generalizada, localizada e cefálica. $\mathrm{Na}$ forma generalizada verifica-se hipertonia muscular responsável por sinais característicos da doença: trismo (comprometimento dos músculos masseteres), riso sardônico, opistótono (espasmo dorsal persistente), rigidez abdominal, convulsões e espasmos musculares. A forma localizada, na qual a doença permanece restrita à musculatura no local da infecção primária, caracteriza-se por hipertonia e espasmos musculares limitados, quase que exclusivamente aos grupos musculares inervados pelas vias neurais, que irradiam a toxina na região do ferimento. E a forma cefálica, que pode levar o paciente ao óbito por insuficiência respiratória decorrente de espasmos da glote ou laringe (BIER, 1978a; MURRAY et al., 2000).

O tétano neonatal é causado pela contaminação do coto umbilical, progredindo para intoxicação generalizada, devido ao uso de instrumentos inadequadamente esterilizados ou por hábitos tradicionais impróprios e prejudiciais presentes em algumas áreas rurais do país para cicatrização do cordão umbilical, como o uso de teia de aranha, pó de café, fumo, esterco etc (FUNASA, 2002). Saliente-se que o tétano neonatal é um dos principais problemas de saúde, com um número estimado de 500.000 casos ocorrendo anualmente em todo planeta, sendo que essa cifra pode ser ainda superior por se tratar de uma doença que apresenta sérios problemas de notificação, uma vez que a maioria dos casos ocorre em áreas rurais onde se 
encontram os serviços mais precários de saúde pública e registros de nascimentos. Face à extrema importância dessa doença estabeleceu-se, em 2005, a meta de redução do tétano neonatal para 1/1.000 nascidos vivos em cada cidade de todos os países membros da World Health Organization (WHO), United Nations Children's Fund (UNICEF) e United Nations Population Fund (UNFA) (WORLD HEALTH ORGANIZATION, 2007).

A imunidade ao tétano é conferida apenas pela vacinação apropriada com três doses de Toxóide Tetânico (TT), ou com as vacinas Tríplice bacteriana (DTP), Dupla para uso infantil (DT), Dupla para uso adulto (dT) e Tetravalente (DTP+HiB), tendo em vista que o processo infeccioso não confere imunidade. Já na profilaxia após ferimento, quando há recomendação de imunização passiva aplica-se o soro antitetânico ou, preferencialmente, imunoglobulina humana antitetânica; essa é especialmente indicada para pessoas que manifestaram reação de hipersensibilidade após receber qualquer soro heterólogo. Ademais, a imunoglobulina humana é predominantemente da classe $\operatorname{IgG}$, que neutraliza eficazmente a toxina obtida do plasma de doadores voluntários selecionados e capazes de produzir altos títulos de anticorpos neutralizantes específicos (SÃO PAULO, 2004). Após a purificação das imunoglobulinas, obtém-se uma solução concentrada de antitoxina de maior eficiência (SANTA ROSA, 1979).

Os esforços empregados para manutenção de altas coberturas vacinais, com a vacinação de crianças menores de um ano e a revacinação com a vacina Dupla para uso adulto (dT) a cada 10 anos, têm sido responsáveis pela situação de controle do tétano no Brasil; ademais, o Ministério da Saúde, para fortalecer seu controle, introduziu a vacinação antitetânica com vacina Dupla para adultos na campanha de vacinação dos idosos (FUNASA, 2002).

Em 1974, a WHO criou o Expanded Programme on Immunization (EPI) com a finalidade de prevenir a ocorrência de mortes em crianças provocadas por doenças que poderiam ser prevenidas por seis vacinas infantis: contra a difteria, coqueluche, tétano, poliomielite, sarampo e tuberculose. Posteriormente, incluiu-se no EPI as vacinas conjugadas contra a Hepatite B e para Haemophilus influenzae tipo B - HiB (EHRETH, 2003). No Brasil, criou-se, em 1973, o Programa Nacional de Imunizações (PNI) que redundou no controle de doenças que afligiam milhares de crianças brasileiras. O PNI implantou a vacinação de adultos, em especial mulheres em idade fértil e idosos a partir de 60 anos. Os idosos são imunizados contra gripe, tétano e difteria, já as mulheres com idade entre 12 e 49 anos recebem a dupla bacteriana, contra tétano e difteria. A cobertura vacinal obtida por este programa, contra difteria, coqueluche e tétano, em menores de um ano, foi de $94,7 \%$ e os investimentos na compra de imunobiológicos em 2000 foram na ordem de 
R\$ 234.000.000,00. Saliente-se que nos laboratórios nacionais são produzidas $75 \%$ das vacinas consumidas no Brasil (MINISTÉRIO DA SAÚDE, 2008).

No cenário nacional, o Instituto Butantan tem importância vital, visto que, além de realizar pesquisa básica da melhor qualidade (em 2006, dentre as Universidades e Institutos brasileiros, foi a instituição com artigos mais citados mundialmente), produz quinze tipos diferentes de soros, entre antipeçonhentos para tratamento de pacientes acidentados por serpentes, aranhas, escorpiões e lonomia, antitóxicos dirigidos para difteria, tétano e botulismo e o antiviral antirábico. Produz, ainda, seis tipos de vacinas utilizadas para prevenção de tétano, difteria, coqueluche, hepatite, raiva e gripe (CANTER e SILVA, 2000). O Instituto Butantan também produz a anatoxina tetânica em escala industrial objetivando o preparo de Toxóide Tetânico (TT), e as vacinas combinadas Dupla - para uso adulto (dT), vacina Dupla - para uso infantil (DT), vacina Tríplice (DTP) e vacina Tetravalente (DTP + Hib), além de antígenos para imunização de eqüinos soroprodutores.

Os esquemas de imunização de eqüinos baseiam-se em inoculações de antígenos que estimulem a produção de anticorpos específicos em títulos elevados. As principais dificuldades encontradas durante a produção dos soros hiperimunes ocorrem devido aos antígenos que, em sua maioria, possuem baixa imunogenicidade e/ou apresentem atividade tóxica que provoquem reação local ou sistêmica. O adjuvante utilizado atualmente é o incompleto de Freund, composto por uma emulsão óleo-água, que provoca reação local intensa, bem como reações sistêmicas indesejadas pelos atuais conceitos éticos em experimentação animal (O'HAGAN et al., 1997). Lembrando: adjuvante deriva do latim adjuvare, que significa ajudar, termo empregado para designar qualquer substância que, sem ser imunogênica, aumente a resposta imune celular e/ou humoral a um dado imunógeno (GUPTA et al., 1993; SCHIJNS, 2000; PETROVSKY e AGUILAR, 2004).

Outros adjuvantes comumente utilizados são os sais de alumínio, como o fosfato de alumínio - $\mathrm{Al}(\mathrm{PO})_{4}$ - e hidróxido de alumínio - $\mathrm{Al}(\mathrm{OH})_{3}$ - os únicos autorizados para uso humano até o licenciamento na Europa do MF59 (GUPTA e SIBER, 1994; COX e COULTER, 1997; GIUDICE et al., 2002; JEFFERSON et al., 2004; McKEE et al., 2007). Esses adjuvantes, embora considerados seguros, ocasionalmente provocam reações locais, tais como eritema, nódulos subcutâneos e inflamação granulomatosa. Tanto em animais como em humanos os adjuvantes à base de alumínio induzem a produção de imunoglobulina $\mathrm{E}$ (IgE) com conseqüentes reações alérgicas, além de não serem eficientes para alguns antígenos. Além disso, o acúmulo sistêmico de alumínio, que ocorre em alguns pacientes com disfunção renal, tem sido associado com disfunções do sistema nervoso e doenças ósseas. No entanto, o 
acúmulo de alumínio derivado da presença em vacinas é menor quando comparado com aquele proveniente de dietas e medicamentos como os antiácidos (GUPTA e SIBER, 1994; AGGERBECK e HERON, 1995; JEFFERSON et al., 2004).

Com o intuito de simplificar as metodologias de vacinação através do aumento de componentes e conseqüente decréscimo do número de doses aplicadas, torna-se cada vez mais necessária a introdução de novos adjuvantes (COX e COULTER, 1997). Face ao quantitativo de imunológicos produzidos pelo Instituto Butantan justifica-se o interesse em se estudar o desenvolvimento e emprego de outros adjuvantes, sem comprometimento da qualidade e custo dos produtos; além disso, ao serem usados no preparo de vacinas e antígenos empregados na imunização de eqüinos, espera-se que os novos adjuvantes tenham a capacidade de se ligar a uma molécula antigênica, aumentando a massa molecular do inóculo e, conseqüentemente, retardando o tempo de eliminação pelas células apresentadoras de antígeno, interferindo positivamente na apresentação, ativação e expansão de células T e B.

Estudo anteriormente realizado no Instituto Butantan analisou preparações de veneno de Bothrops jararaca conjugadas ao polietilenoglicol (PEG); verificou-se a diminuição em pelo menos 50\% de sua toxicidade, além de outras vantagens significativas (STEPHANO, 2005). Esse polímero sintético é compatível com o organismo, sendo utilizado pelas indústrias farmacêuticas, alimentícias e também de cosméticos; é, ainda, um produto antigenicamente inerte e atóxico (SCHELLEKENS, 2002), podendo ser obtido com vários graus de polimerização, como: o PEG 80, que é líquido, ou o PEG 500 sólido - o numerador é indicador do número de monômeros na cadeia (DUNCAN e SPREAFICO, 1994).

A inserção de grupamentos de polietilenoglicóis em cadeias de proteínas, ou mais especificamente enzimas, tem sido estudada para a terapia de doenças crônico-degenerativas como câncer e processos autoimunes. Entretanto, quando administrada diretamente na corrente sanguínea, existe a possibilidade da proteína ser reconhecida como estranha, desde que muitas das enzimas utilizadas experimentalmente sejam originárias de espécies animal, vegetal ou de microrganismos. Assim, o sistema imune do paciente poderá produzir anticorpos específicos contra a proteína administrada e, no caso de administração contínua da mesma substância, desenvolver reações indesejáveis como choque anafilático, eventualmente fatal. Ressalte-se que essas ocorrências imunológicas encontradas com drogas enzimáticas ou imunoglobulinas podem ser reduzidas pelo uso de drogas que contenham PEG. Portanto, espera-se das proteínas conjugadas a esses polímeros as seguintes propriedades: manutenção da atividade enzimática, redução de reatividade imune nociva, aumento da meia vida do composto e indução de tolerância imunológica (INADA et al., 1995; KODERA et al., 1998; 
ROBERTS et al., 2002).

As proteínas tratadas com monometoxi-polietilenoglicol (mPEG), apesar de não serem reconhecidas pelos anticorpos alostéricamente, por impedimento de acesso ao seu sítio antigênico, apresentam a capacidade de induzir respostas celular e humoral amplificadas à proteína nativa quando comparadas com a proteína sem tratamento (KODERA et al., 1998; CALICETI et al., 1999).

O presente estudo objetivou gerar conhecimento sobre o preparo de antígenos com toxicidade reduzida ou nula para a imunização de eqüinos soroprodutores. Os dados obtidos com o tratamento da toxina tetânica pelo mPEG poderão ser aplicados para outros antígenos de interesse na produção de imunobiológicos. 


\section{REVISÃO DA LITERATURA}

\subsection{Tétano}

\subsubsection{Aspectos Históricos}

Inúmeros estudiosos, há séculos, têm relatado o tétano como uma doença responsável pela perda de centenas de milhares de vidas, concentradas principalmente em uma grande parte do mundo onde a vacinação não era obrigatória (SCHIAVO et al., 2000).

Seu nome deriva da palavra grega tétanos, que significa contração, tendo sido descrita no papiro descoberto por Edwin Smith do antigo Egito (1600 a.c.), nos escritos de Aristóteles (400 a.c.) e nos textos Ayurvedicos da Índia Antiga (400 d.c.) (THWAITES, 2005).

Com efeito, a doença é descrita tanto na bíblia como nos escritos dos antigos médicos gregos e egípcios (MALLICK e WINSLET, 2004), dentre os quais Hipócrates descreveu, há 25 séculos, os sintomas de paralisia de um paciente com hipercontratura muscular esquelética (SCHIAVO et al., 2000).

Hipócrates fez uma das primeiras observações detalhadas sobre o tétano, descrevendo-o sob as formas generalizada e localizada, declarando: Tetânico que passar do $4^{\circ}$ dia, estará salvo. Lamentava Hipócrates que o médico nada podia fazer para curar seus infelizes pacientes. Uma ferida grave contaria com essa terrível eventualidade, sobretudo se ocorresse num terreno cultivado (ADAMS et al., 1969).

Aretaeus da Capadócia, no século I d.c., fez uma descrição do que era presenciar o terrível sofrimento do doente:

\footnotetext{
Uma calamidade desumana. Um quadro indescritível. Uma doença incurável. O médico embora presente e preocupado, nenhuma assistência pode fornecer para salvar a vida, aliviar a dor ou as deformidades. Para conseguir repor em posição o corpo de um homem vivo ele deveria cortá-lo e quebrá-lo. Para com estes que são tomados pela doença ele pode apenas ficar compadecido. Esta é a grande desventura do médico (FINEGOLD, 1977).
}

O tétano fez, freqüentemente sozinho, depois de um combate de média importância, mais vítimas que toda uma batalha na Época Contemporânea. As probabilidades de cura eram muito reduzidas, a morte variava de 70\% a 95\% (DRIGALSKI e LOT, 1959). 
No início do século XIX, em 1801, Pierre Dufouart, cirurgião militar da Revolução Francesa, atribuiu, pela primeira vez, o tétano a um vírus, afirmando que se a raiva era devida a um vírus, também o era o tétano (TAVARES, 1975).

Em 1813, um médico de Halle, o professor I. C. Reil, descreve como se apresentava a freqüência do trismo (contração dolorosa dos músculos mastigadores) na batalha de Leipzig: trismo, sinal clínico de uma terrível complicação infecciosa das chagas, o tétano.

Um soldado é ferido não gravemente por um tiro ou uma arma branca e então imagina logo que tendo escapado ao massacre ele se encontra fora de combate. De repente sente uma sensação desagradável em seu queixo. Não pode mais abrir a boca, sente toda a face tornar-se rígida, sua boca se encrispa, e ele se põe a fazer caretas - como maldosamente - é isso o "riso sardônico", outro terrível sintoma. O desgraçado ringe os dentes, revira a cabeça para trás, depois o corpo todo se sustenta enquanto todos os músculos se contraem - e, no meio de infernais sofrimentos, o doente parece rir, com este riso careteiro. Estas crises intoleráveis de rigidez convulsiva se sucedem sem trégua e as mais ligeiras excitações - um barulho, uma corrente de ar... - bastam para provocar o acesso. O doente não pode mais encontrar o sono nem se alimentar, a respiração se faz cada vez mais curta e mais difícil, é a pior das agonias. Quem assistir por uma só vez a cena semelhante não a esquecerá jamais (DRIGALSKI e LOT, 1959).

James Young Simpson, em 1854, correlaciona o tétano obstétrico ao traumático e admite que a doença é causada por um veneno semelhante à estricnina, presente nos ferimentos (KADIS et al., 1971).

Em 1884, Antonio Carle e Giorgio Rattone demostraram a transmissibilidade do tétano provocando a doença em coelhos ao injetar pus da acne de um caso fatal de tétano em humano (TAVARES, 1975; SIMONSEN, 1989; HUMEAU et al., 2000; MALLICK e WINSLET, 2004). Definiu-se, então, que o tétano é uma moléstia infecciosa (TAVARES, 1975).

No mesmo ano, o médico alemão Arthur Nicolaier provocou o tétano em animais injetando amostras de solo contaminado (MALLICK e WINSLET, 2004) e concluiu que o agente do tétano é um bacilo anaeróbio, difícilmente obtido em cultura pura e facilmente encontrado no solo, transmissível aos animais, não invasivo e produtor de um veneno de ação semelhante à estricnina. Assim, o agente etiológico do tétano ficou conhecido como o bacilo de Nicolaier (TAVARES, 1975).

Entretanto, foi o bacteriologista japonês Shibasaburo Kitasato, em 1889, que isolou e produziu cultura pura do C. tetani do organismo de um caso humano e verificou que a toxina 
poderia ser neutralizada por anticorpos específicos (SCHIAVO et al., 2000; MALLICK e WINSLET, 2004).

Em 1892, o biólogo alemão Emil Adolf von Behring (prêmio Nobel de Medicina de 1901) verificou que a adição de tricloreto de iodo à toxina tetânica torna-a um produto atóxico, mas dotado de propriedades vacinantes (BIER, 1978a).

O veterinário e biólogo francês Edmond Isidore Etienne Nocard, em 1897, demonstrou os efeitos protetores da antitoxina transferida passivamente, de forma que a imunização passiva em humanos foi utilizada durante a Primeira Guerra Mundial (MALLICK e WINSLET, 2004).

Edward Löewenstein, em 1909, estudou a ação do formol sobre a toxina tetânica e concluiu a forma de obtenção de um derivado absolutamente atóxico, dotado de capacidade vacinante e de poder de combinação comparáveis aos da toxina original (BIER, 1978a).

No Brasil, a partir de 1921, José Lemos Monteiro, no Instituto Butantan, idealizou uma técnica para estabelecer a proporção de formalina, que ao se combinar com a toxina, preparada em seu laboratório, transformar-se-ia em toxóide em um curto período de tempo. Enfim, que se tornasse atóxica para a cobaia, embora suas propriedades imunogênicas fossem conservadas (MONTEIRO, 1925).

Em 1925, o Toxóide Tetânico (toxina tratada com formalina) foi preparado pela primeira vez por Gaston Ramon e Pierre Descombey; em 1926, Gaston Ramon e Christian Zoeller utilizaram a vacina para imunização humana, e na década de 40, deu-se o início da produção em larga escala (SIMONSEN, 1989). A efetividade da imunização ativa foi demonstrada na Segunda Guerra Mundial, na qual as tropas americanas e inglesas imunizadas contra o tétano apresentaram incidência da doença aproximadamente dez vezes menor que na Primeira Guerra Mundial, quando não se praticou a vacinação (DIAS DA SILVA, 1989; SIMONSEN, 1989; MALLICK e WINSLET, 2004).

Cerca de um século após as primeiras descobertas, determinou-se a seqüência dos aminoácidos da toxina tetânica (EISEL et al., 1986) e se decifrou o mecanismo intracelular de ação de tal toxina (SCHIAVO et al., 1992ab; HUMEAU et al., 2000).

\subsubsection{Clostridium tetani}

O Clostridium tetani é um bacilo Gram positivo, anaeróbio estrito, que no processo de formação de esporo possui característica de baqueta ou aparência de raquete de tênis [Figura 1]. Os esporos estão universalmente presentes no solo e no trato gastrointestinal de animais 
(incluindo humanos), podendo contaminar superfícies e substâncias. São extremamente resistentes e hábeis para sobreviver durante muitos anos sob condições adversas. Assim, para serem destruídos, os esporos devem ser submetidos a autoclavação a $121{ }^{\circ} \mathrm{C}$, durante 10 a 15 minutos, ou expostos por tempo prolongado ao iodo, peróxido de hidrogênio, formalina ou glutaraldeído (MALLICK e WINSLET, 2004; ROPER et al., 2007).

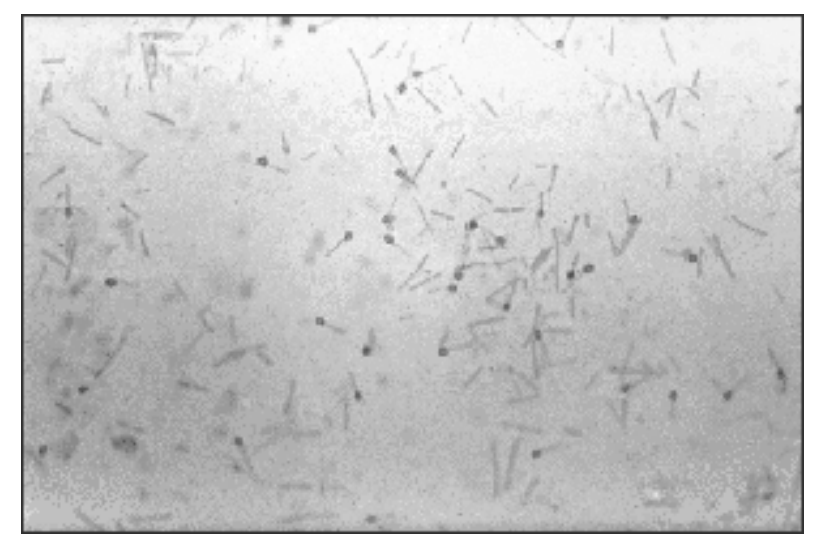

Figura 1 - Clostridium tetani.

Figura original: http://microbes.historique.net/tetani.html.

O C. tetani não possui enzimas para a redução do oxigênio e, assim, a presença do mesmo conduz a bactéria à morte; presente na natureza, na forma de esporos, germinam quando em condições favoráveis, como baixa tensão de oxigênio, ligeira acidez e disponibilidade de nutrientes. Tais condições podem ser encontradas em ferimentos profundos, rupturas da pele ou escoriações (ainda menores do que aqueles causados por piercing ou tatuagens), onde os esporos podem germinar e produzir a proteína tóxica, denominada neurotoxina tetânica (TeNT), que completa o citosol da bactéria e é liberada por autólise (SCHIAVO et al., 2000; THWAITES, 2005).

Saliente-se que as seqüências do DNA tanto da bactéria como da toxina já são conhecidas (THWAITES, 2005). Em 1984, demonstrou-se pela primeira vez que a toxina tetânica é codificada em grande plasmídeo denominado pCL1, isolado da cepa Massachusetts (FINN et al., 1984), e em 1986, a seqüência completa do nucleotídeo da toxina tetânica (TxT) foi determinada (EISEL et al., 1986; FAIRWEATHER e LYNESS, 1986). A seqüência completa da tet $X$, do plasmídeo do C. tetani foi estabelecida recentemente (BRÜGGEMANN et al., 2003; BRÜGGEMANN e GOTTSCHALK, 2004). Conclui-se, ainda, que o C. tetani é um patogeno anaeróbio invasivo, possuidor de vasto arsenal de fatores virulentos, exarcebado pela capacidade em produzir a toxina tetânica e possivelmente pela presença de diversos SLPs 
(array of surface-layer proteins) com funções ainda desconhecidas. A performance do íon de sódio pode ser um fator adicional para a invasão bem sucedida do tecido infectado. A seqüência genômica do C. tetani forneceu informações acerca dos sistemas regulatórios, viabilizando o estudo da via do sinal transdutor que leva a expressão da toxina tetânica (BRÜGGEMANN et al., 2003).

\subsubsection{Toxina Tetânica}

A TeNT é responsável por todos os sintomas do tétano. A dose letal 50\% $\left(\mathrm{DL}_{50}\right)$ em camundongos está entre 0,1 e $1 \mathrm{ng}$ toxina/ $\mathrm{Kg}$ de peso corporal, sendo que diferentes espécies animais demonstram uma grande variedade de sensibilidade à TeNT. Nesse sentido, humanos e cavalos são no mínimo tão sensíveis a esta neurotoxina quanto os camundongos, enquanto os ratos, pássaros, cobras e anfíbios são mais resistentes à TeNT, e as tartarugas são insensíveis (SCHIAVO et al., 2000).

O C. tetani produz duas toxinas: a tetanolisina e a tetanospasmina. O significado clínico da tetanolisina é desconhecido, entretanto, sabe-se que ela é inibida pelo oxigênio e colesterol sérico e está sorologicamente relacionada a outras hemolisinas de clostrídeos e à estreptolisina O. Já a tetanospasmina é sintetizada durante a fase estacionária de crescimento, liberada quando a célula é lisada e responsável pelas manifestações clínicas do tétano (BIER, 1978a; MURRAY et al., 2000).

Elucidar a estrutura da toxina tetânica tornou-se essencial para o conhecimento do mecanismo de ação dessa proteína que exerce profundos efeitos neurotóxicos em quantidades mínimas (HELTING e ZWISLER, 1977); diante desse fato, por várias décadas diversos autores dedicaram-se à avaliação da citada estrutura.

Estudos realizados na década de 70 demonstraram que a toxina extracelular é separável em duas cadeias polipeptídicas (cadeia pesada e cadeia leve), ambas ligadas por uma ponte dissulfidíca. Relatou-se, outrossim, a conversão da toxina tetânica intracelular em extracelular pela digestão com tripsina. Os dois fragmentos foram denominados $\alpha$ e $\beta$, sendo aparentemente similares às cadeias polipeptídicas leve e pesada, respectivamente (MATSUDA e YONEDA, 1974; MATSUDA e YONEDA, 1976; HELTING et al., 1979). Entretanto, esses fragmentos tratados com dodecil sulfato de sódio (SDS) ou guanidina perderam a toxicidade e a atividade imunoquímica (MATSUDA e YONEDA, 1975).

Demonstrou-se, ainda, que tanto a toxina tetânica extracelular como a intracelular (tratada com tripsina) podem ser reversivelmente dissociadas como fragmentos polipeptídicos 
complementares à forma íntegra da toxina em termos de peso molecular, toxicidade e antigenicidade. O sucesso na dissociação reversível da toxina deve-se, sobretudo, ao uso de uréia na concentração de $4 \mathrm{M}$, a qual, quando superior a esse índice, aumenta a quantidade de materiais agregados que não possuem reatividade imunoquímica e, quando inferior, resulta em dissociações incompletas dos fragmentos (MATSUDA e YONEDA, 1975).

Saliente-se que um método altamente reprodutível de degradação da toxina tetânica com papaína resultando em um polipeptídio atóxico e imunogênico, denominado fragmento $\mathrm{C}$, foi descrito por Helting e Zwisler (1977). Além disso, o fragmento B, porção complementar, formado quando o fragmento $\mathrm{C}$ é liberado da toxina tetânica, também foi identificado. Confirmou-se também a estrutura da cadeia polipeptídica da toxina tetânica estudada por Craven e Dawson (1973) e Matsuda e Yoneda (1974) e um procedimento de digestão com papaína foi apresentado para preparar formas estáveis de fragmento B e C. No tocante ao fragmento $\mathrm{C}$, comprovou-se ser ele derivado da cadeia pesada polipeptídica da toxina tetânica, com massa molecular de $47.000 \pm 5 \%$, o que representa cerca de $1 / 3$ da molécula da toxina. $O$ fragmento $C$, além de ser atóxico, apresentou atividade imunogênica estimulando a formação de anticorpos neutralizantes da ação letal da toxina tetânica in vivo. Já o fragmento B, isolado por digestão pela papaína, continha duas cadeias polipeptídicas unidas por pontes dissulfídicas e massa molecular de $95.000 \pm 5 \%$. Tal fragmento também se apresentou atóxico e, quando analisado por imunodifusão, não apresentou identidade com o fragmento $\mathrm{C}$ ao ser colocado frente à antitoxina tetânica. Concluiu-se que o fragmento B contém uma porção complementar da cadeia pesada (remanescente após a quebra da ligação polipeptídica liberando o fragmento C) ligada à cadeia leve por ligações dissulfídicas (HELTING e ZWISLER, 1977).

A toxina tetânica apresenta duas formas moleculares desta proteína. A molécula da toxina liberada pelo C. tetani é uma cadeia de polipeptídio simples e se tem demonstrado que a toxina intracelular pode ser obtida pela interrupção da fermentação antes da lise, seguida de extração da bactéria coletada com solução de sais. Alternativamente, uma forma extracelular da toxina tetânica pode ser recuperada dos filtrados da cultura autolisada (HELTING et al., 1979).

Estudos realizados posteriormente relatam que, após a lise celular, a toxina tetânica, que é uma cadeia polipeptídica simples de massa molecular igual a $150.000 \mathrm{Da}$, é liberada no meio e clivada por uma protease endógena (quando a célula libera a neurotoxina) resultando em uma cadeia leve (L) de $\mathrm{NH}_{2}$ terminal de 52.300 Da (fragmento A - [Figura 2a]) e uma cadeia pesada $(\mathrm{H})$ de $\mathrm{COOH}$-terminal de $98.300 \mathrm{Da}$ (fragmento $\mathrm{B}-\mathrm{C}-$ [Figura 2a]). As duas 
cadeias são unidas por uma ligação dissulfeto e por forças não-covalentes (RAPPUOLI, 1997; TURTON et al., 2002; LALLI et al., 2003).

A toxina pode ser recuperada intacta da bactéria lavada através da extração com solução hipertônica neutra e, quando tratada com papaína, produz um fragmento A-B de $\mathrm{NH}_{2}$ terminal de 99.000 Da e um fragmento C de COO-H terminal de 51.500 Da (RAPPUOLI, 1997).

Os fragmentos A e B-C não são tóxicos, quando purificados, mas no caso de reassociação dos mesmos, a toxicidade é restabelecida. O fragmento purificado $\mathrm{C}$ é absolutamente não tóxico, enquanto o fragmento A-B produz paralisia flácida ao invés de paralisia espástica, característica da toxina tetânica. A toxina pode ser neutralizada por anticorpos monoclonais ligando o fragmento $\mathrm{A}, \mathrm{B}$ ou $\mathrm{C}$, sugerindo que, teoricamente, qualquer um dos três fragmentos não tóxicos poderia ser usado como vacina. Os fragmentos $\mathrm{A}, \mathrm{B}$ e $\mathrm{C}$ têm sido usados para imunização de camundongos contra o tétano, com êxito (RAPPUOLI, 1997).

A toxina tetânica liga-se aos gangliosídeos e proteínas dos nervos terminais periféricos por meio do $\mathrm{COOH}$ - terminal do fragmento $\mathrm{C}$; é, então, internalizada e transportada retrogradamente pelas terminações nervosas da coluna espinhal, onde produz a paralisia espástica seguida de convulsões. A cadeia leve da toxina tetânica é uma zinco metaloprotease que cliva, com extraordinária especificidade, a sinaptobrevina, uma parte fundamental da proteína de membrana da vesícula presináptica. Uma vez que a sinaptobrevina é clivada, as vesículas são incapazes de se fundir às membranas da célula e liberar os neurotrasmissores. A representação esquemática da estrutura funcional da toxina tetânica e de seu modo de ação estão demonstrados nas Figuras 2b e 2c, respectivamente (RAPPUOLI, 1997).

A cadeia polipeptídica da TeNT possui 1.315 resíduos de aminoácidos. Já a cadeia leve (L) possui 449 resíduos de aminoácidos [Figura 3] e a cadeia pesada $(\mathrm{H}) 857$ [Figura 4 e 5] (SCHIAVO et al., 2000). 


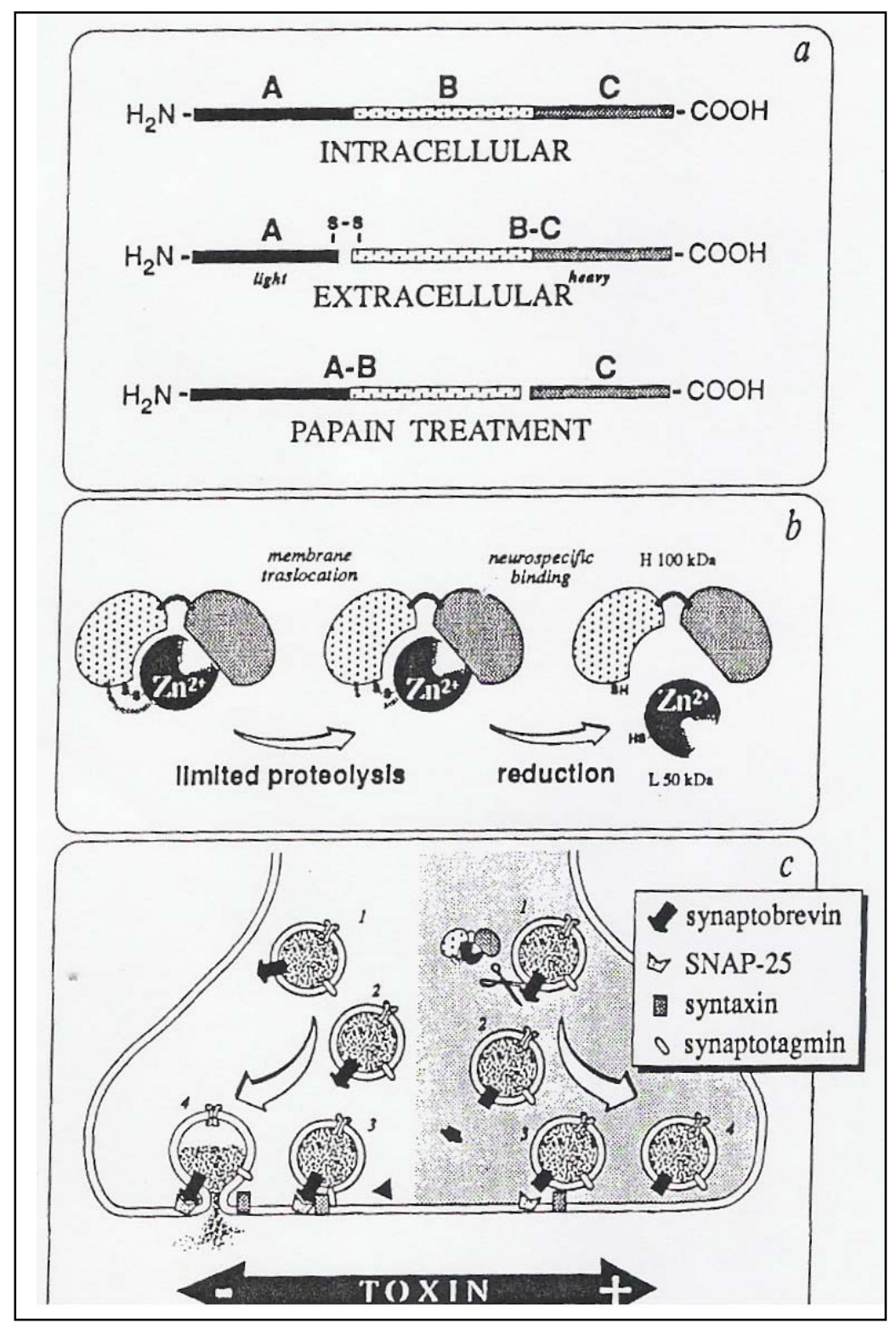

Figura 2 - Estrutura da toxina tetânica. (A). Demonstrando o domínio estrutural principal e suas funções (B). Mecanismo de ação da toxina: a toxina cliva a sinaptobrevina e, portanto inibe a fusão das vesículas contendo os neurotransmissores com a membrana (C). Figura original: RAPPUOLI, 1997. 


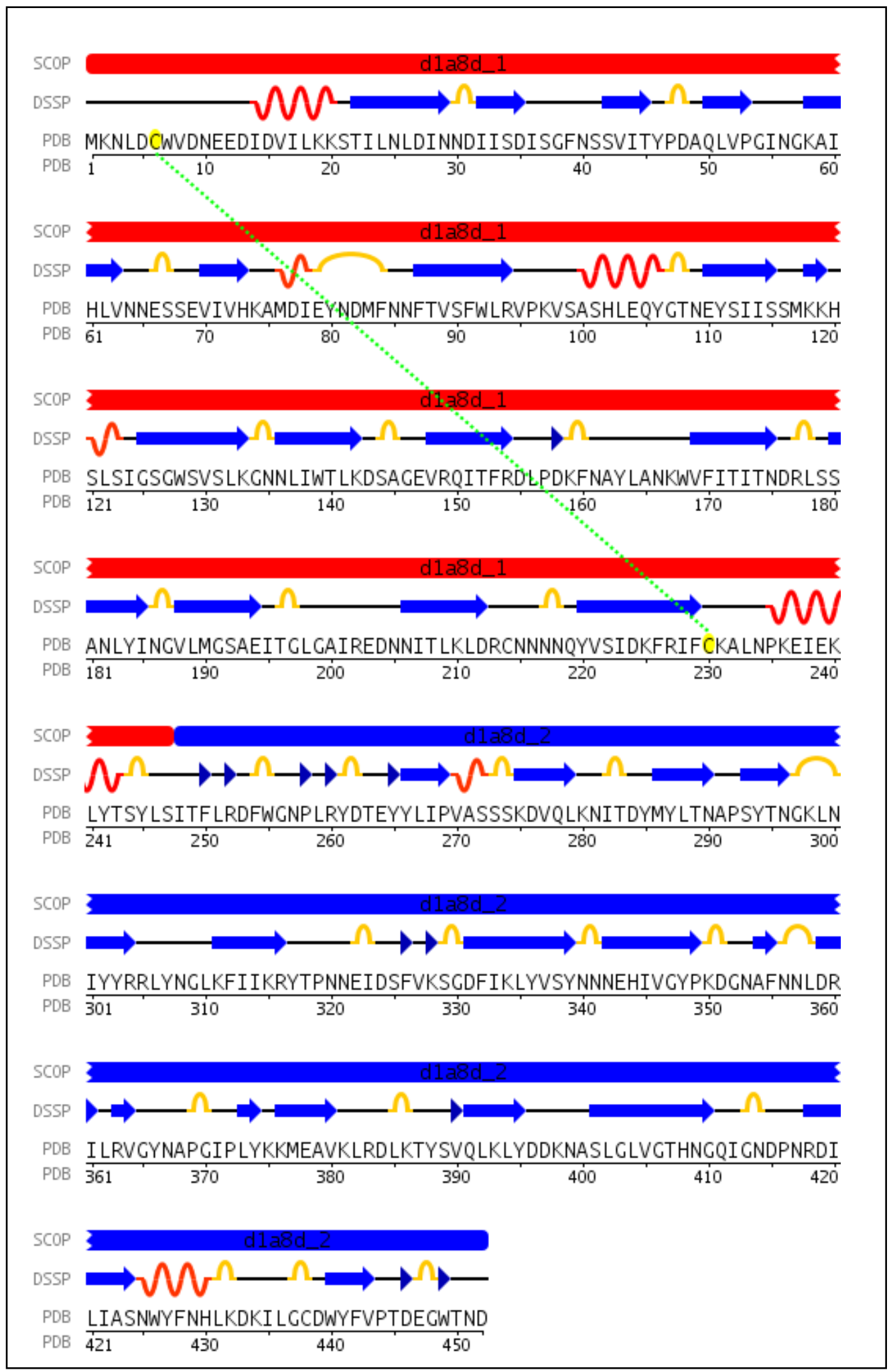

Figura 3 - Seqüência primária e secundária da cadeia leve (L) com 449 resíduos de aminoácidos. Depositada no Research Collaboratory for Structural Bioinformatics (RCSB) sob o código 1a8d (KNAPP et al., 1998).

Figura original: RESEARCH COLLABORATORY FOR STRUCTURAL BIOINFORMATICS, 2007. 


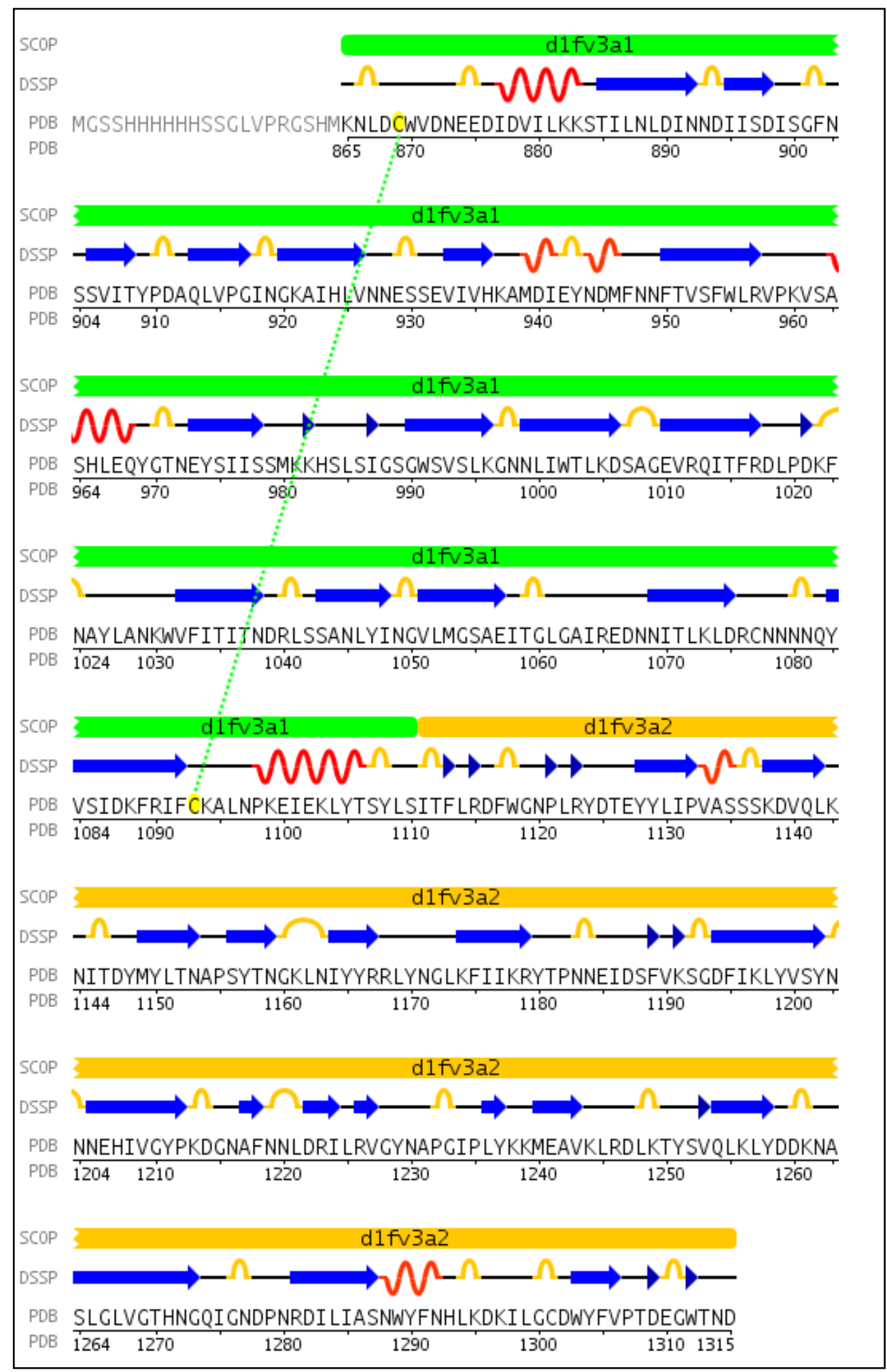

Figura 4 - Seqüência primária e secundária da cadeia (A) polipeptídica da TeNT com 1.315 resíduos de aminoácidos. Depositada no RCSB sob o código 1fv3 (FOTINOU et al., 2001). Figura original: RESEARCH COLLABORATORY FOR STRUCTURAL BIOINFORMATICS, 2007. 


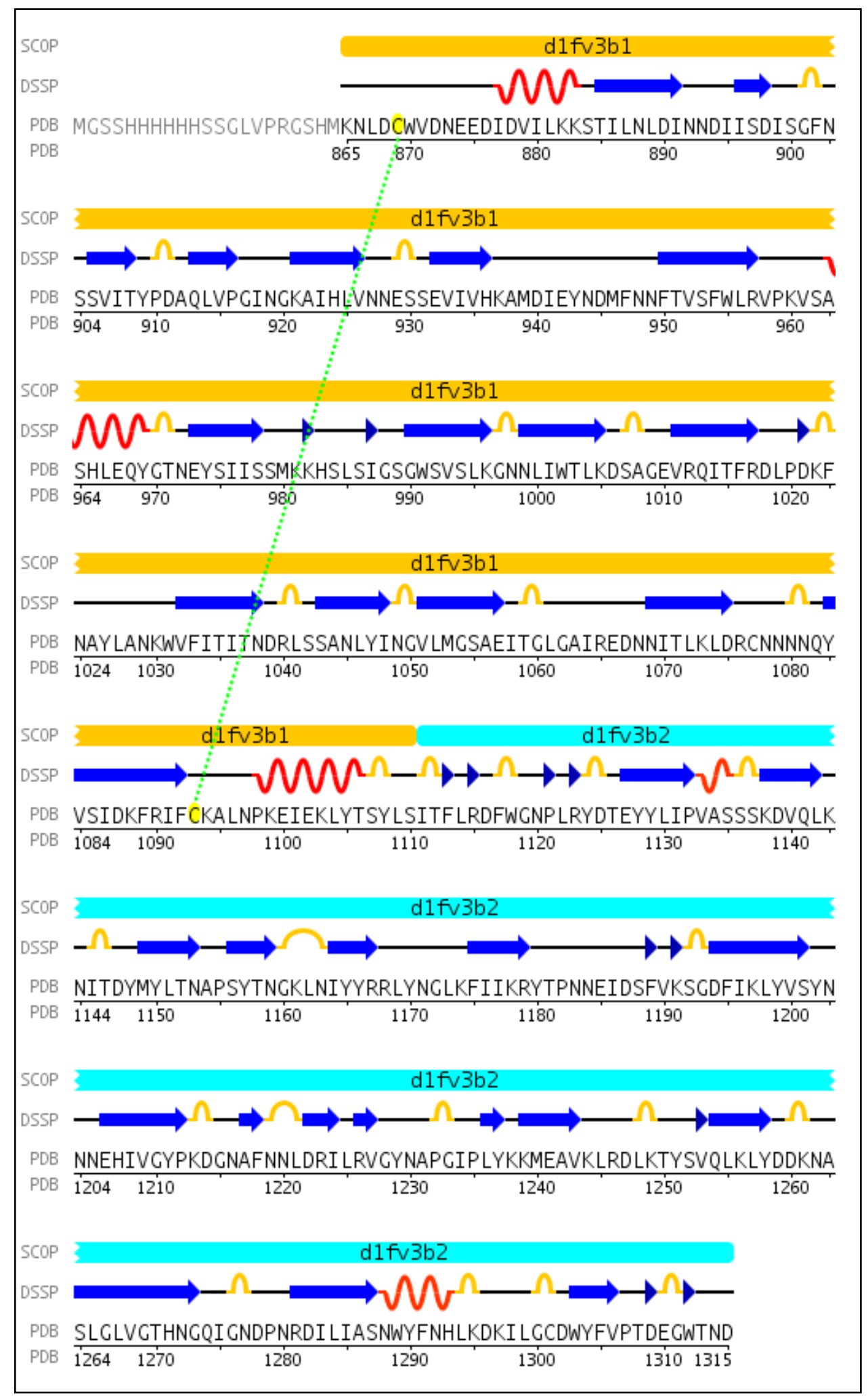

Figura 5 - Seqüência primária e secundária da cadeia (B) polipeptídica da TeNT com 1.315 resíduos de aminoácidos. Depositada no RCSB sob o código 1 fu3 (FOTINOU et al., 2001).

Figura original: RESEARCH COLLABORATORY FOR STRUCTURAL BIOINFORMATICS, 2007. 
A toxina tetânica é produzida pelo C. tetani como uma cadeia simples, que é prontamente clivada por proteases sendo geradas duas cadeias ativas, quais sejam a cadeia pesada (H) com $100 \mathrm{kDa}$ e a cadeia leve (L) com 50 kDa (SCHIAVO et al., 1992a; QAZI et al., 2007). A cadeia H relaciona-se com ligações celulares neuroespecíficas enquanto a cadeia L é responsável pela inativação de componentes chaves da maquinaria de neuroexocitose (SCHIAVO et al., 1992a).

A principal ação da toxina tetânica baseia-se na interferência da transmissão neuromuscular através da interrupção da comunicação entre os neurônios medulares inibitórios ao bloquear a liberação de neurotransmissores inibitórios (glicina e GABA-ácido $\gamma$ aminobutírico) (HUMEAU et al., 2000; LALLI et al., 2003). Ressalte-se que tal interrupção resulta em convulsões, hiper-reflexia e espasmos musculares generalizados (SCHWAB et al., 1979; BERGEY et al., 1983; VALLEE e BLOOM, 1991; MONTECUCCO e SCHIAVO, 1995).

A toxina tetânica e a toxina botulínica formam a família das neurotoxinas clostridiais e são as causadoras do tétano e do botulismo, respectivamente. Ambas são estruturalmente organizadas em três domínios responsáveis por funções distintas: alta afinidade de ligação aos neurônios, translocação de membrana e clivagem específica de proteínas controladoras de neuroexocitose [Figura 6]. Descobertas recentes em relação ao mecanismo de recrutamento de membrana e a colocação dessas neurotoxinas nos neurônios fazem delas uma ferramenta ideal para desvendar aspectos essenciais da fisiologia neuronal na saúde e na doença (TURTON et al., 2002; LALLI et al., 2003; FOTINOU et al., 2001; QAZI et al., 2007). 


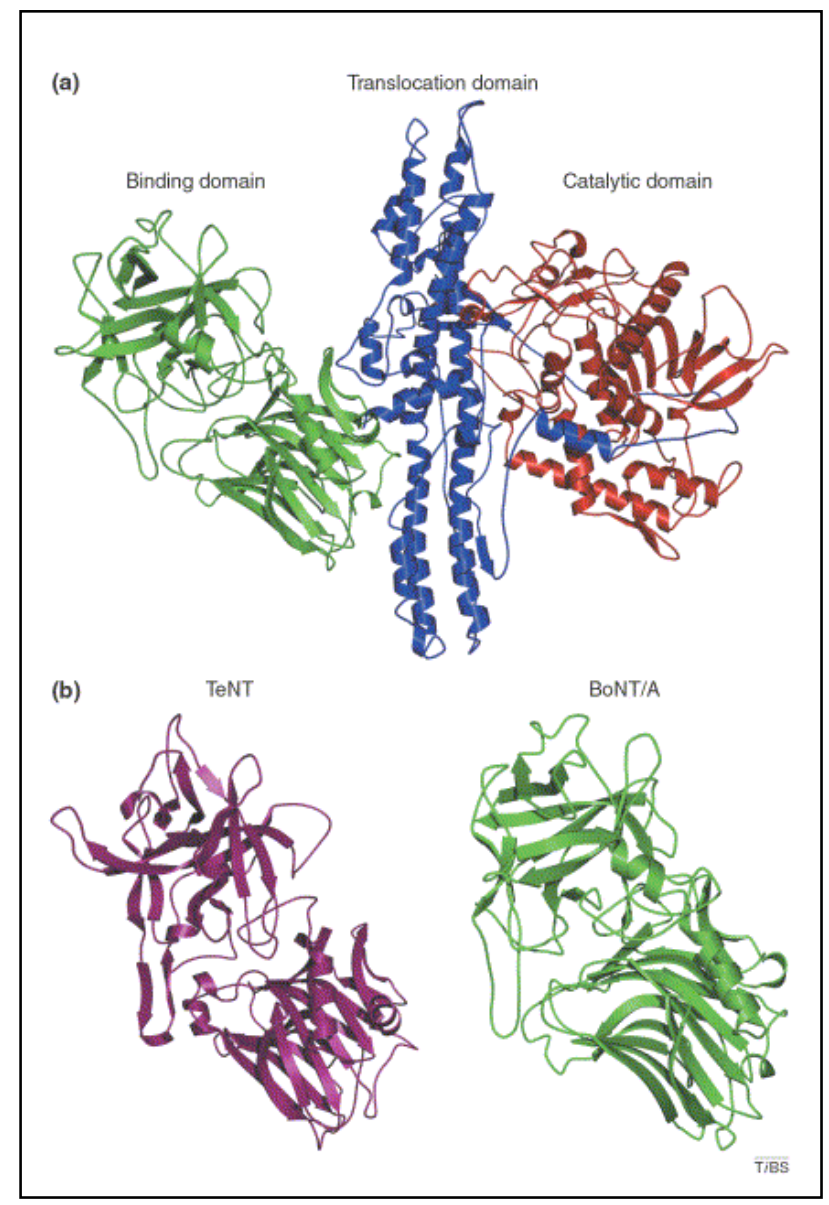

Figura 6 - (A) Estrutura cristalina das neurotoxina botulínica A (BoNT/A). Os três domínios funcionais são estruturalmente distintos: domínio catalítico, domínio de translocação e domínio de ligação. (B) O domínio de ligação da neurotoxina tetânica (TeNT) está representado em rosa e da neurotoxina botulínica tipo A (BoNT/A) em verde. A Figura representa uma organização similar entre a estrutura da TeNT e BoNT/A.

Figura original: TURTON et al., 2002.

A estrutura das neurotoxinas clostridiais revelam três domínios distintos funcionais [Figura 7]. Semelhante organização estrutural é relatada quando as neurotoxinas clostridiais intoxicam os neurônios por via de mecanismo de quatro etapas, que consistem em: 1) ligação; 2) internalização; 3) translocação da membrana; e, 4) modificação do sítio catalítico (SCHIAVO et al., 2000).

A cadeia leve (L) é responsável pela atividade catalítica intracelular e a cadeia $\mathrm{H}$ é subdividida em dois domínios, $\mathrm{H}_{\mathrm{N}}$ (amino terminal) e $\mathrm{H}_{\mathrm{C}}$ (carboxi terminal). $\mathrm{O} \mathrm{NH}_{2}$ - de $50 \mathrm{kDa}$, domínio da cadeia pesada $\left(\mathrm{H}_{\mathrm{N}}\right)$, está relacionado com a translocação da membrana, enquanto que a porção terminal $\mathrm{COOH}-\left(\mathrm{H}_{\mathrm{C}}\right)$ é a principal responsável pela ligação neuroespecífica (AHNERT-HILGER et al., 1990; SCHIAVO et al., 1992ab; SCHIAVO et al., 2000). 


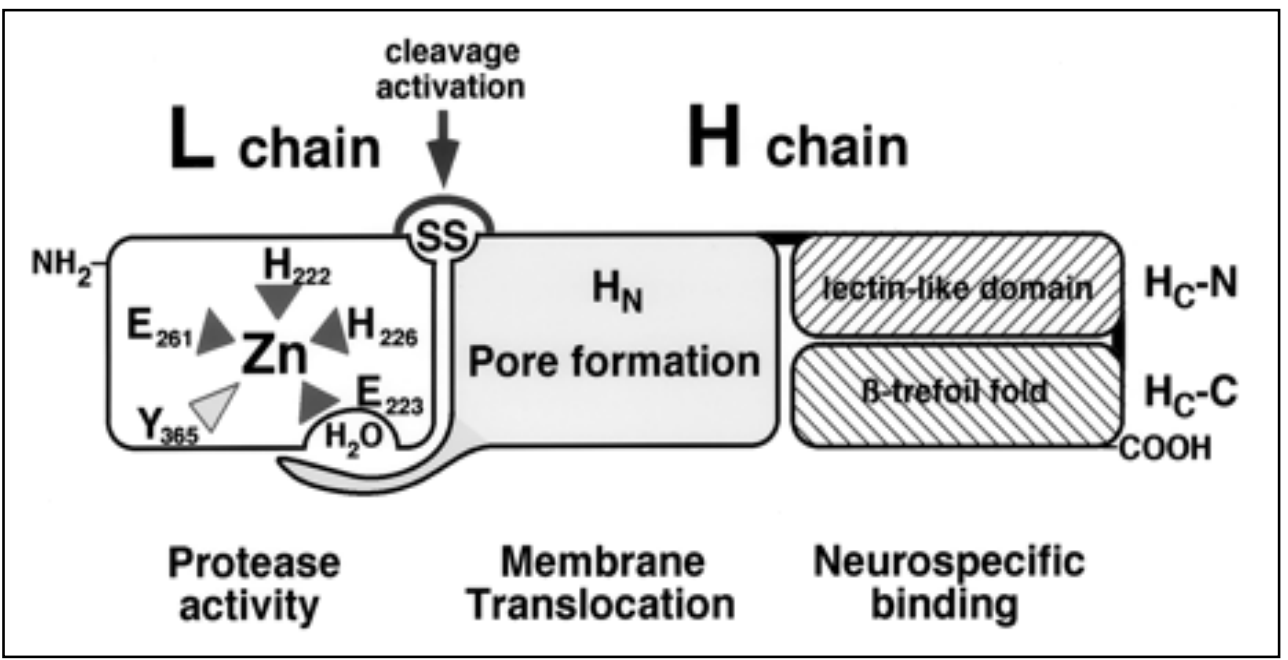

Figura 7 - Diagrama da estrutura do domínio das neurotoxinas clostridiais. Os três domínios possuem tamanho similar $(50 \mathrm{kDa})$. O domínio terminal $\mathrm{NH}_{2}$ - é uma endopeptidase dependente de zinco que é inativa quando a ponte dissulfídica está ligada ao restante da molécula. $\mathrm{O}$ domínio central $\mathrm{H}_{\mathrm{N}}$ é responsável pela translocação da membrana da cadeia $\mathrm{L}$ para o citosol do neurônio. $\mathrm{O}$ domínio $\mathrm{H}_{\mathrm{C}}(\mathrm{COOH}$ - terminal) apresenta dois subdomínios de mesma massa $\left(\mathrm{H}_{\mathrm{C}}-\mathrm{N}\right.$ e $\left.\mathrm{H}_{\mathrm{C}}-\mathrm{C}\right)$, sendo responsável pela ligação da toxina ao receptor.

Figura original: SCHIAVO et al., 2000.

$\mathrm{O}$ domínio $\mathrm{H}_{\mathrm{C}}$ liga-se a gangliosídeos de nervos periféricos, lipídeos, proteínas transmembranas e proteínas ancoradas com glycophosphoinositol (GPI), tidos como prováveis receptores para a toxina tetânica, os quais estariam localizados em grupos no interior da estrutura APR (array of presynaptic receptors) [Figuras 7 e 8]. Entende-se que a ligação inicial do mencionado domínio, ocorrida em razão de sua interação com um oligossacarídeo ligado a um lipídio [G, Figura 8], deve ser rápida, reversível e com afinidade de ligação moderada, ocorrida provavelmente no exterior da APR e para a qual a toxina ligada à membrana seria levada por meio de movimentos laterais rápidos após a interação inicial. No processo de invaginação o domínio $\mathrm{H}_{\mathrm{C}}$ liga-se aos demais receptores e, conseqüentemente, a interação do domínio $\mathrm{H}_{\mathrm{C}}$ com a membrana torna-se praticamente irreversível (SCHIAVO et al., 2000; MONTECUCCO et al., 2004; GUILHEN, 2005). 


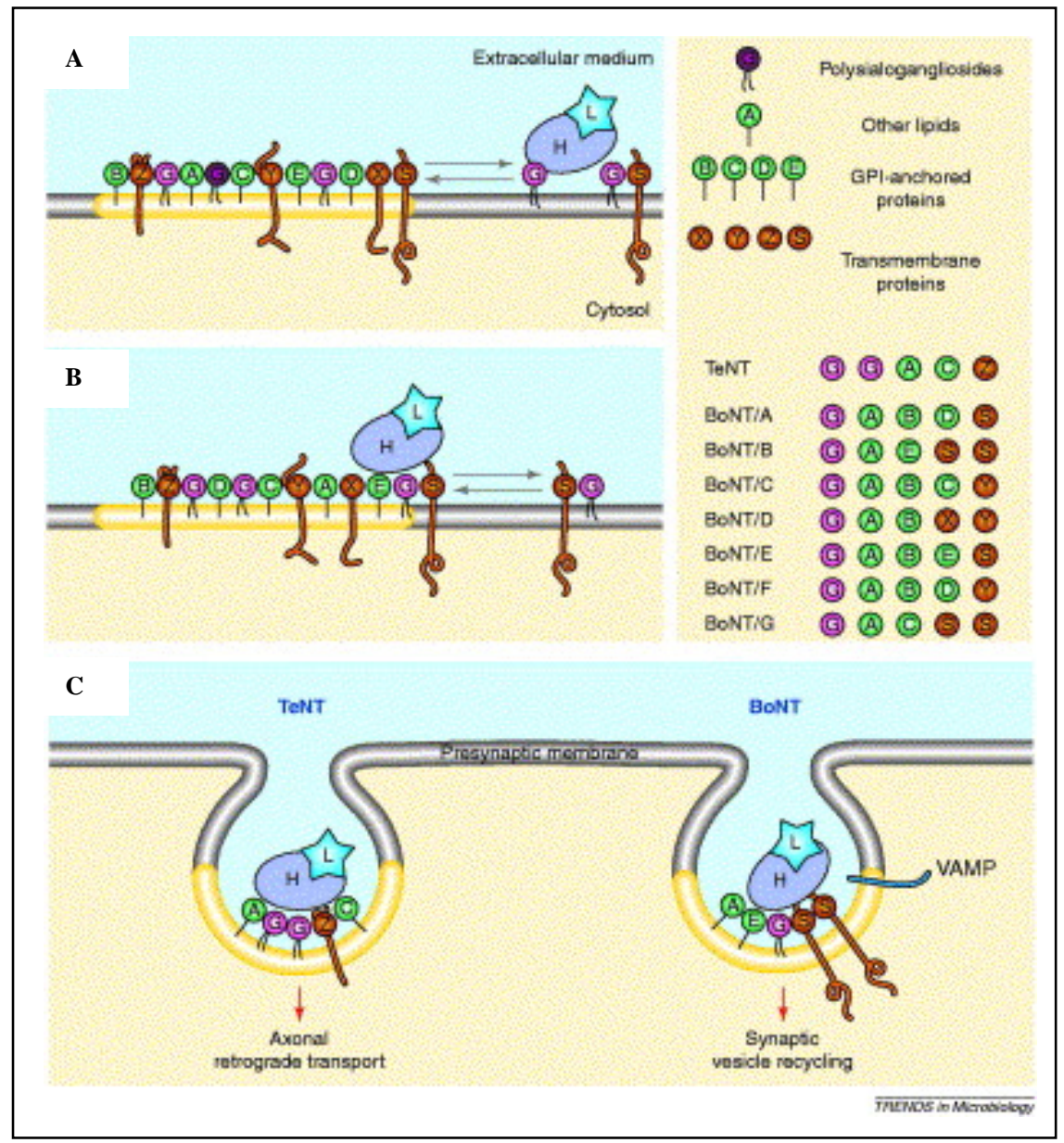

Figura 8 - Ligação e endocitose da toxina tetânica via múltiplos receptores da membrana. Os receptores da toxina tetânica estão no interior da estrutura APR (array of presynaptic receptors) em amarelo. A cadeia pesada da Toxina Tetânica está representada por $\mathrm{H}$ e a cadeia leve por $L$; os gangliosídeos por $G$ (polysialogangliosides); os lipideos por $A$; as proteinas transmembrana por $X, Y, Z$ e $S$; e as proteínas ancoradas $G P I$ por $B, C, D$ e $E$. Etapa inicial (A): interação da toxina tetânica a receptores. Etapa intermediária (B): interação aos demais receptores localizados na estrutura APR. Etapa final (C): invaginação e ligação da toxina tetânica à molécula $Z$.

Figura original: MONTECUCCO et al., 2004.

Após a internalização da toxina tetânica e, por meio de transporte axonal retrógrado, a toxina é conduzida aos neurônios inibitórios do sistema nervoso central, sendo ligada a uma molécula não definida, denominada como $\mathrm{Z}$ na Figura 8, que pode ser responsável pelo direcionamento da mesma para o transporte retrógrado [Figura 9] (MONTECUCCO et al., 2004; GUILHEN, 2005). 
A cadeia leve é, então, translocada para o citosol dos neurônios motores inibitórios por meio do domínio amino terminal da cadeia pesada $\left(\mathrm{H}_{\mathrm{N}}\right)$. Relevante hipótese para a translocação da cadeia $\mathrm{L}$ diz respeito à formação de uma fissura na membrana, em ambiente de $\mathrm{pH}$ baixo, por duas sub unidades do domínio $\mathrm{H}_{\mathrm{N}}$, que possuem uma região hidrofóbica. Em razão do ambiente ácido, a cadeia L apresenta-se em forma linear, o que permite a sua passagem pelo canal formado recuperando sua formação nativa após a translocação, quando em pH neutro do citosol (MONTECUCCO et al., 2004; GUILHEN, 2005).

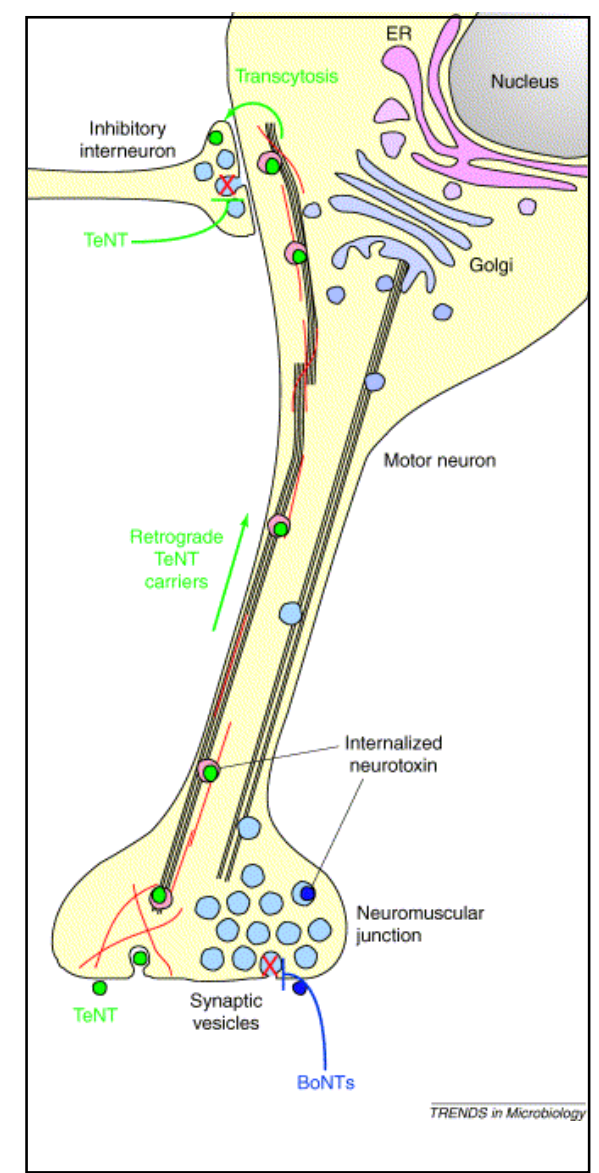

Figura 9 - Neurônio motor de mamífero e interação de interneurônio inibitório da coluna espinhal. Os locais de ação da TeNT (em verde) e das BoNTs (em azul) estão demonstrados juntamente com a rota de tráfego intracelular das mesmas (transporte retrógrado). A cruz em vermelho, na região superior esquerda da Figura, indica o local de liberação do neurotransmissor pela toxina tetânica.

Figura original: LALLI et al., 2003. 


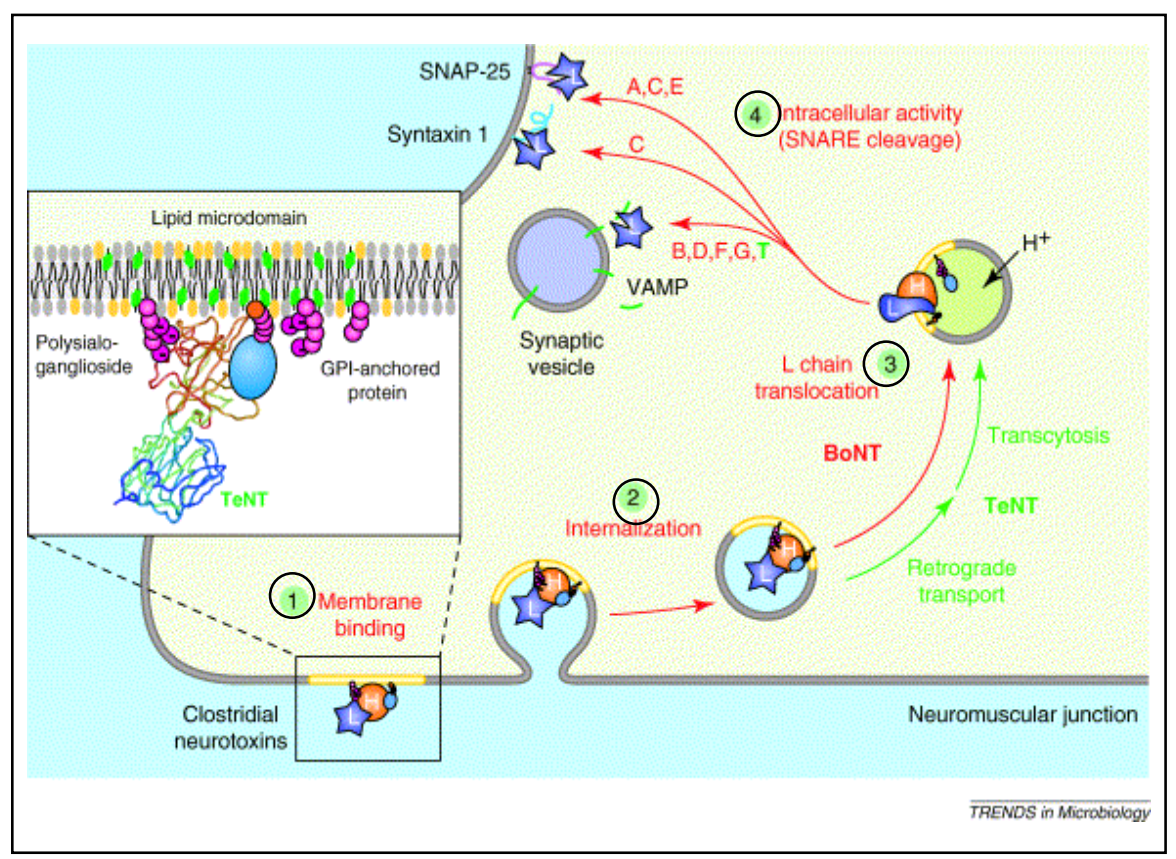

Figura 10 - Mecanismo de ação da toxina tetânica. Esquema demonstrando as quatro etapas do mecanismo de entrada e inibição dos neurônios pelas neurotoxinas tetânica e botulínica: (1) ligação na membrana, (2) internalização, (3) translocação; e, (4) ação intracelular. Figura original: LALLI et al., 2003.

A cadeia leve (L) da toxina (zinco endopeptidase) é responsável pela atividade proteolítica intracelular, presente no citosol dos neurônios inibitórios no sistema nervoso central e, cliva a proteína de membrana de vesícula sináptica denominada VAMP (vesicle associated membrane protein) [Figura 10] ou sinaptobrevina, componente do complexo SNARE (soluble NSF attachment protein receptor), responsável pela liberação dos neurotransmissores (SCHIAVO et al., 1992ab; TURTON et al., 2002; LALLI et al., 2003; MONTECUCCO et al., 2004; GUILHEN, 2005).

A tetanospasmina atua ao bloquear a liberação de neurotransmissores em sinapses inibitórias ao nível da coluna vertebral, causando, assim, uma desregulação da atividade sináptica excitatória com conseqüente paralisia espástica, característica do tétano. A ligação da toxina é irreversível, de modo que a recuperação depende da formação de novas terminações axonais (RAPPUOLI, 1997; GUILHEN, 2005). 


\subsubsection{O Processo de Destoxificação da Toxina Tetânica}

De acordo com Rappuoli (1994), no início da década de 20, Gaston Ramon, trabalhando no Instituto Pasteur (Paris, França), usou o formaldeído como preservativo para o sobrenadante de culturas tóxicas de Corynebacterium diphtheriae. Ele descobriu que, uma vez armazenado, o sobrenadante da cultura não apenas perdia a capacidade de matar animais, mas fazia com que se tornassem resistentes a um subseqüente desafio com o sobrenadante de uma cultura tóxica. A partir dessa observação ele concluiu que o formaldeído poderia ser utilizado para destoxificar a toxina diftérica destinada à produção de vacina. Assim, essa tecnologia passou a ser utilizada para inativar toxina tetânica, células bacterianas íntegras e vírus. Entretanto, segundo Brown (1995), Alexander Thomas Glenny, no Laboratório Physiological Wellcome (Inglaterra), utilizava o formaldeído desde 1904 para o mesmo propósito, cujo estudo foi publicado em 1921, enquanto que o trabalho de Gaston Ramon foi publicado apenas em 1924.

É importante ressaltar que essas duas atividades do formaldeído, isto é, inativação da toxicidade e estabilização dos antígenos durante longos períodos de estocagem, têm se confirmado há muitos anos. O tratamento pelo formaldeído ainda é uma das etapas na produção de muitas vacinas bacterianas e virais, e tanto a toxina diftérica como a tetânica têm sido destoxificadas pelo formaldeído através do método descrito por Gaston Ramon, em 1924. Esse método ainda é o utilizado para destoxificar novas toxinas que são candidatas a componentes de vacina, como por exemplo a toxina pertussis (RAPPUOLI, 1994).

Durante o processo de destoxificação o formaldeído reage com as moléculas da toxina, peptonas e outras proteínas presentes no meio. A primeira reação envolve, em especial, grupos de $\varepsilon$-amino de lisina, sendo rápida e completamente reversível [Figura 11] (RAPPUOLI, 1997).

$$
\mathrm{R}-\mathrm{NH}_{2}+\mathrm{H}_{2} \mathrm{CO} \rightleftharpoons \mathrm{R}-\underset{\mathrm{H}}{\rightleftharpoons}-\mathrm{CH}_{2} \mathrm{OH} \stackrel{\mathrm{H}^{+}}{\rightleftharpoons} \stackrel{\stackrel{\mathrm{H}^{+}}{\mathrm{N}}=}{=} \mathrm{CH}_{2}+\mathrm{H}_{2} \mathrm{O}
$$

Figura 11 - Representação da reação promovida pelo formaldeído em grupos amina (RAPPUOLI, 1997). 
O resultado final do tratamento da toxina por formaldeído envolve cross-linkage entre um grupo $\varepsilon$-amino de lisina e um segundo grupo amino [Figura 12-1], uma histidina [Figura 12-2] e uma tirosina ou um triptofano [Figura 12-3] através de uma ponte estável de metileno $\left(-\mathrm{CH}_{2}-\right)$ (RAPPUOLI, 1997).

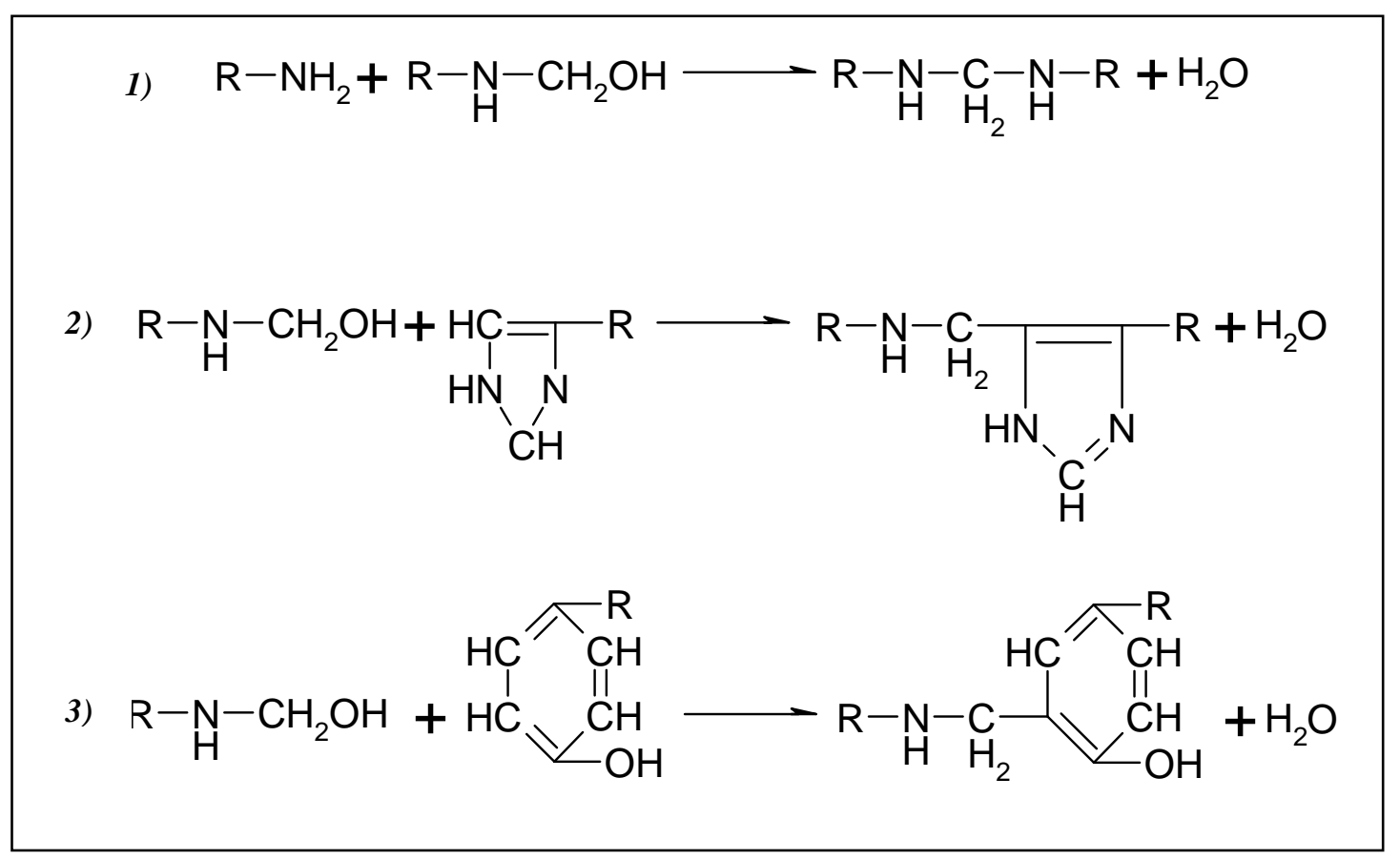

Figura 12 - Resultado final do tratamento da toxina tetânica pelo formaldeído (RAPPUOLI, 1997).

\subsubsection{Epidemiologia}

O tétano continua sendo considerado uma importante causa mundial de morbidade e mortalidade, afetando por volta de setecentos mil a um milhão de pessoas todo ano. No Reino Unido os casos são sub reportados numa estimativa de $54 \%$ a $64 \%$, de forma que apenas quatro casos foram notificados em 2002. No mesmo ano, vinte e cinco casos foram relatados nos Estados Unidos da América (E.U.A.), sendo que a maioria ocorreu em pacientes idosos, nos quais a concentração dos anticorpos no soro são mais baixas. Um estudo recente, que abrangeu cento e oitenta mil pessoas nos E.U.A., demonstrou que apenas 50\% das pessoas com mais de 60 anos possuíam concentrações adequadas de anticorpos antitetânicos. Entretanto, pessoas não vacinadas de qualquer idade estão em situação de risco, conforme demonstrado em recente estudo envolvendo usuários de drogas injetáveis no Reino Unido, onde vinte casos ocorreram desde julho de 2003 (THWAITES, 2005).

A ocorrência do tétano é mundial, mas é considerado um problema comum em áreas de clima quente densamente povoadas, nas quais o solo é rico em material orgânico. A 
incidência do tétano em países de clima temperado como a Inglaterra e o País de Gales, diminuiu pela introdução da imunização nacional em 1961. Em média seis casos de tétano clínico por ano foram reportados na Inglaterra e no País de Gales entre os anos de 1992 e 2002 (MALLICK e WINSLET, 2004).

No passado, o tétano foi prevalente no mundo, porém, atualmente, é pouco incidente nos países desenvolvidos, nos quais se observa melhoria das ações de prevenção, como aumento de coberturas vacinais na infância e ações educacionais e sociais. Já nos países subdesenvolvidos e em desenvolvimento, a doença ainda é um problema de saúde pública (GUIMARÃES, 2005).

No Brasil, o tétano acidental é evitado pela vacinação antitetânica, repetida a cada 10 anos, o que reduziu a sua ocorrência de 2.226 casos em 1982 para 366 em 2001. Essa infecção também apresentou um deslocamento da faixa etária mais acometida, com cerca de $50 \%$ dos casos ocorrendo em pessoas idosas. Por conta dessa característica, o Ministério da Saúde, com o objetivo de fortalecer a estratégia de controle da citada doença, introduziu a vacinação antitetânica com vacina Dupla para uso adulto (dT) na campanha de vacinação do idoso (FUNASA, 2002).

O tétano no idoso deve-se, em grande parte, à queda linear dos níveis séricos da antitoxina tetânica com o avançar da idade, à imunossenescência com prejuízo da atividade T-helper e à negligência nas doses de reforço da vacina antitetânica (MORAES e PEDROSO, 2000).

As mortes pelo tétano acidental também acompanharam a tendência declinante, pois das 713 ocorrências anuais registradas em 1982, passou-se para 86 casos em 2001, indicando uma variação negativa de 83\% (FUNASA, 2002).

Ademais, o Ministério da Saúde do Brasil faz uso de ações que objetivam detectar, notificar, investigar e confirmar casos de tétano, tendo em vista que a ocorrência desses está relacionada à existência de indivíduos suscetíveis (não imunizados contra o tétano) e expostos ao C. tetani através de: ferimento de qualquer natureza em contato com terra, poeira ou excrementos; fratura óssea exposta, com tecidos dilacerados e corpos estranhos; queimadura; mordedura de animais e aborto infectado. Conforme se observa na Tabela 1, a incidência do tétano pelos fatores anteriormente descritos apresenta tendência decrescente em todas as regiões brasileiras, sendo que entre os anos de 1990 e 2005 houve redução de $71 \%$ dos casos no país. É a região Nordeste que concentra o maior número de casos de tétano (cerca de 40\%) (REDE INTEGRADA DE INFORMAÇÕES PARA A SAÚDE, 2007a). 
Tabela 1 - Casos confirmados de tétano (exceto o neonatal), por ano, segundo região do Brasil, 1990 a 2005

\begin{tabular}{l|r|r|r|r|r}
\hline \hline \multicolumn{1}{c|}{ REGIÕES } & \multicolumn{1}{c|}{$\mathbf{1 9 9 0}$} & \multicolumn{1}{c|}{$\mathbf{1 9 9 3}$} & \multicolumn{1}{c}{$\mathbf{1 9 9 6}$} & \multicolumn{1}{c}{$\mathbf{2 0 0 2}$} & \multicolumn{1}{c}{$\mathbf{2 0 0 5}$} \\
\hline BRASIL & 1.548 & 1.282 & 1.025 & 598 & 452 \\
\hline NORTE & 183 & 144 & 129 & 83 & 56 \\
\hline NORDESTE & 622 & 531 & 421 & 226 & 179 \\
\hline SUDESTE & 387 & 277 & 224 & 138 & 102 \\
\hline SUL & 240 & 231 & 179 & 118 & 80 \\
\hline CENTRO-OESTE & 116 & 99 & 72 & 33 & 35 \\
\hline \hline
\end{tabular}

Fonte: Ministério da Saúde/SVS - Sistema de Informação de Agravos de Notificação (SINAN).

Nota: Dados sujeitos à revisão (atualização: setembro/2006).

Original: REDE INTEGRADA DE INFORMAÇÕES PARA A SAÚDE, 2007a.

Nesse sentido, o aumento da cobertura vacinal com a DTP, dT, DT e DTP + Hib, as medidas educativas de prevenção no uso de objetos de proteção e a melhoria no atendimento médico nas emergências, com a correta indicação do tratamento de lesões potencialmente contaminadas, são fatores que colaboraram diretamente na redução da incidência do tétano. Contudo, considera-se que o número de casos permanece elevado, já que se trata de uma doença prevenível (FUNASA, 2002; REDE INTEGRADA DE INFORMAÇÕES PARA A SAÚDE, 2007a).

O tétano nos primeiros 28 dias de vida (tétano neonatal) foi amplamente estudado e reconhecido como uma importante causa de morte neonatal. Entretanto, considerando-se que a maioria dos bebês infectados por essa doença geralmente nasce e morre em casa, não há registro do número real de mortes causada pela doença. Nos anos 70 e 80 , pesquisas sobre o tétano neonatal envolvendo mais de quarenta países demonstraram que menos de $10 \%$ dos casos e mortes relatados foram reportados na maioria dos países, sendo que em algumas regiões a taxa foi reduzida para $2 \%$ a $5 \%$. As estimativas baseadas nos resultados de tais pesquisas, bem como as informações relatadas à WHO, sugerem que na década de 80 mais de um milhão de mortes por ano foram atribuídas ao tétano, sendo que, em 1988, 787.000 mortes foram causadas apenas pelo tétano neonatal (ROPER et al., 2007).

Ressalte-se que o tétano neonatal é uma doença responsável por importante índice de mortalidade infantil; sendo atualmente inexistente nos países desenvolvidos, raro nos países em desenvolvimento, mas ocorrendo com freqüência nos subdesenvolvidos, principalmente na África e sudeste asiático. De um total de 289 mil casos ocorridos em todo mundo em 1999, 124 mil e 91 mil foram registrados nessas duas regiões, respectivamente. A taxa de letalidade foi de 74,3\% (GUIMARÃES, 2005). 
No Brasil, o Ministério da Saúde acompanha a incidência do tétano no período neonatal (até 28 dias após o nascimento). Essa ocorrência de tétano é um marcador de deficiências na qualidade de atenção pré-natal, ao parto e ao recém-nascido, que favorecem a infecção pelo C. tetani. Essas deficiências referem-se à vacinação de gestantes contra o tétano e aos cuidados de assepsia no parto e no tratamento do coto umbilical do recém-nato, estando associadas, em geral, às baixas condições socioeconômicas da população. O tétano neonatal tende a ocorrer em situações (parto no domicílio, geralmente em áreas rurais, sem assistência médica ao recém-nascido) que favorecem a subnotificação de casos (REDE INTEGRADA DE INFORMAÇÕES PARA A SAÚDE, 2007b).

Ademais, o aludido órgão assumiu o compromisso internacional de eliminar o tétano neonatal, adotando a estratégia de melhorar a vigilância epidemiológica e vacinar todas as mulheres em idade fértil nos municípios de maior risco, concentrados nas regiões Norte e Nordeste. A redução do número de casos do tétano neonatal foi de 584 em 1982 para 34 casos em 2001. As mortes por essa causa também foram reduzidas em 17 vezes, de 470 ocorrências em 1982 para 27 em 2001 (FUNASA, 2002).

Conforme se observa na Tabela 2, a incidência do tétano neonatal apresenta tendência decrescente em todas as regiões brasileiras. Entre os anos de 1990 e 2005, o número de casos no país diminuiu de 291 para 10. Entretanto, a maior concentração dos casos permanece nas regiões Norte e Nordeste do país, em decorrência de condições socioeconômicas e do difícil acesso aos serviços de saúde, principalmente no Norte (REDE INTEGRADA DE INFORMAÇÕES PARA A SAÚDE, 2007b).

Tabela 2 - Casos confirmados de tétano neonatal, por ano, segundo região do Brasil, 1990 a 2005

\begin{tabular}{l|r|r|r|r|r|r}
\hline \hline \multicolumn{1}{c|}{ REGIÕES } & \multicolumn{1}{c|}{1990} & \multicolumn{1}{c|}{1993} & \multicolumn{19}{c|}{$\mathbf{1 9 9 6}$} & $\mathbf{1 9 9 9}$ & \multicolumn{1}{c|}{$\mathbf{2 0 0 2}$} & \multicolumn{2}{c}{$\mathbf{2 0 0 5}$} \\
\hline BRASIL & 291 & 215 & 93 & 66 & 35 & 10 \\
\hline NORTE & 44 & 47 & 14 & 16 & 10 & 4 \\
\hline NORDESTE & 152 & 113 & 54 & 27 & 18 & 6 \\
\hline SUDESTE & 29 & 29 & 15 & 10 & 3 & - \\
\hline SUL & 32 & 10 & 4 & 7 & 1 & - \\
\hline CENTRO-OESTE & 34 & 16 & 6 & 6 & 3 & - \\
\hline \hline
\end{tabular}

Fonte: Ministério da Saúde/SVS - Sistema de Informação de Agravos de Notificação (SINAN).

Nota: Dados sujeitos à revisão (atualização em setembro/2006).

Original: REDE INTEGRADA DE INFORMAÇÕES PARA A SAÚDE, 2007b. 
Considera-se que a diminuição do número de casos de tétano neonatal esteja relacionada com o aumento da cobertura vacinal sistemática realizada com o TT ou vacina dT, em mulheres de idade fértil, principalmente nas áreas de risco; e à melhoria da atenção básica (Programas de Saúde da Família e de Agentes Comunitários) (REDE INTEGRADA DE INFORMAÇÕES PARA A SAÚDE, 2007b).

O Brasil já atingiu a meta de incidência inferior a um caso de tétano neonatal por 1.000 nascidos vivos (0,009 casos/1.000 n.v.), considerada pela Organização Pan-Americana da Saúde (OPAS) como indicativa da eliminação da doença. Todavia, torna-se necessário atingir essa meta em cada um dos municípios brasileiros, aproximando-se de uma ocorrência próxima a zero (FUNASA, 2002).

Em determinados casos já se verificou que em gestantes infectadas por malária ou HIV (human immunodeficiency virus) a imunização padrão foi insuficiente, pois houve redução da transferência transplacentária de anticorpos. Assim, apesar da concentração dos anticorpos maternos, a proteção não foi efetivamente conferida viabilizando o desenvolvimento da doença (MORAES-PINTO et al., 1995; THWAITES, 2005).

A estimativa mundial é de 201.000 mortes causadas anualmente por tétano neonatal. Entretanto, o número total de mortes por tétano é muito maior porque as mães e as crianças mais velhas e outras pessoas também podem ser afetadas. A WHO estima que haja no total cerca de 281.000 mortes a cada ano. Desde o World Summit for Children, em 1993, a WHO tem considerado o tétano neonatal como um problema de saúde pública e tem adotado algumas estratégias para eliminá-lo, dentre as quais se pode citar: garantia que todas as mulheres grávidas recebam no mínimo duas doses da vacina contra o tétano e tenham um parto seguro (FUNDO INTERNACIONAL DE FINANÇAS PARA IMUNIZAÇÃO, 2007).

No inicio da década de 90 , estimou-se que cerca de $5 \%$ da mortalidade maternal ou de 15.000 a 30.000 mortes anuais devia-se ao tétano maternal. Em 1999, estabeleceu-se uma meta para eliminação do tétano maternal, a qual foi incluída em um programa de eliminação dessa doença nomeado Maternal and Neonatal Tetanus Elimination Program. Em quinze anos, o programa gerou grandes progressos, já que a mortalidade mundial pelo tétano neonatal foi estimada em 180 mil casos em 2002, o que representa uma redução de cerca de $78 \%$ desde o final da década de 80 . Atualmente, essa doença representa cerca de $5 \%$ a $7 \%$ da mortalidade neonatal mundial, comparado a 14\% em 1993. Estimativas da atual incidência e da mortalidade pelo tétano maternal não estão disponíveis, contudo, o número de mortes a nível mundial por essa doença provavelmente sofreu uma redução considerável. Nos países desenvolvidos o tétano representa uma curiosidade médica e o tétano neonatal e o maternal 
são extremamente raros. Entretanto, o tétano continua a causar anualmente cerca de 213.000 a 293.000 mortes em todo o mundo, principalmente em países não desenvolvidos ou subdesenvolvidos. As mortes pelo tétano neonatal ou maternal estão concentradas em 48 países especialmente na Ásia e na África [Figura 13] (ROPER et al., 2007).

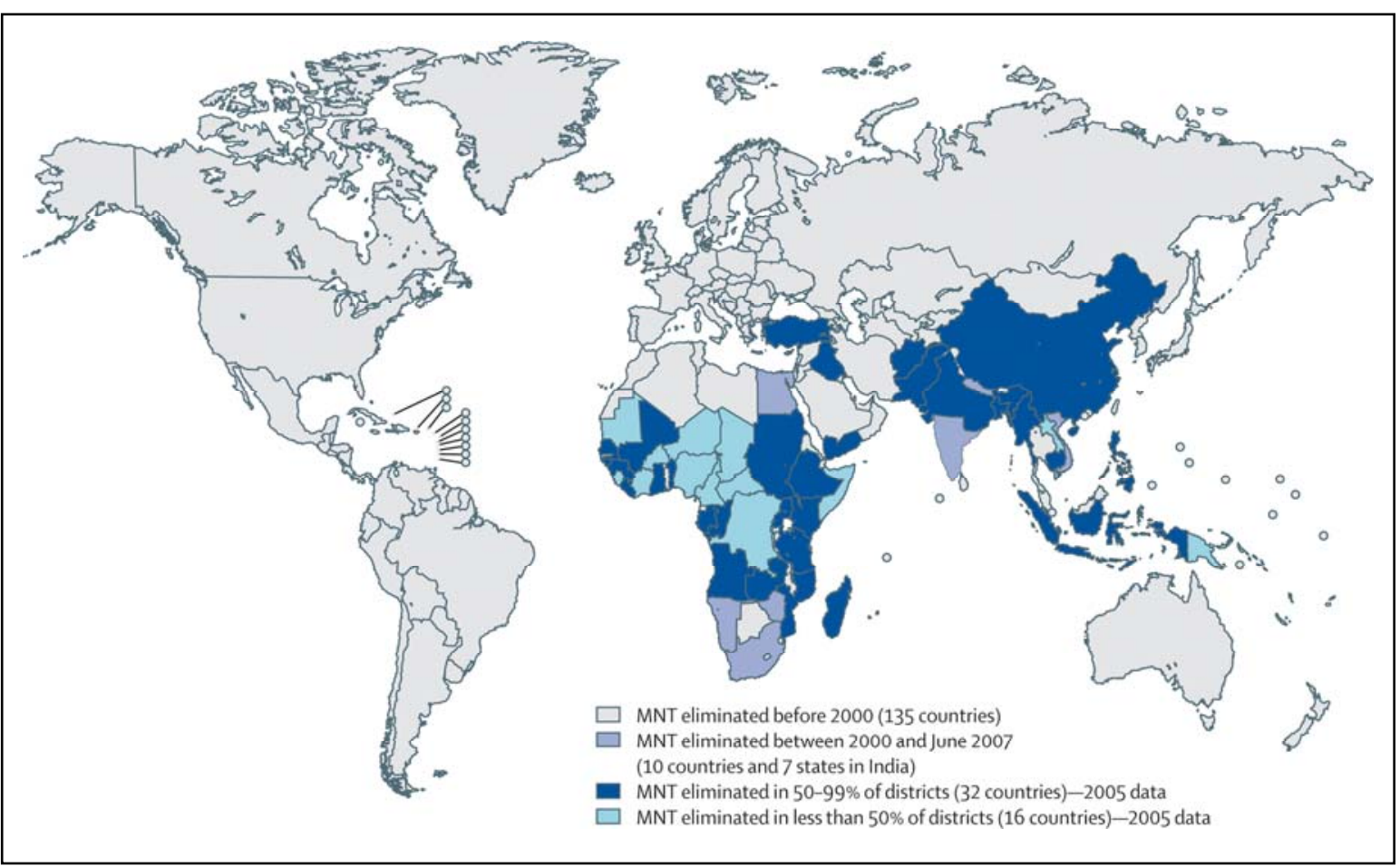

Figura 13 - Status acerca da eliminação por países do tétano neonatal e maternal. Figura original: ROPER et al., 2007.

\subsubsection{Manifestações Clínicas}

O tétano, usualmente de início agudo, resulta do binômio solução de continuidade de pele/mucosa e contaminação pelo C. tetani (MORAES e PEDROSO, 2000) e ocorre após um ferimento de penetração profunda, favorável ao crescimento de bactérias anaeróbicas, principalmente se a ferida for contaminada por solo, adubo (esterco) ou metal enferrujado. A contaminação também pode ocorrer por outros mecanismos, como queimaduras, úlceras, abortos sépticos, circuncisões, injeções intramusculares, acupuntura, piercing em orelha, tatuagens, problemas dentários, otite média crônica e picadas de cobras. Porém, em mais de $30 \%$ dos casos, a "porta de entrada" do C. tetani não é conhecida (GOONETILLEKE e HARRIS, 2004).

Geralmente, o período de incubação (tempo de inoculação até o primeiro sintoma) é de 
7 a 10 dias (extensão de 1-60 dias) e o estabelecimento (tempo desde o primeiro sintoma até o início dos espasmos) de 1 a 7 dias (GOONETILLEKE e HARRIS, 2004). Estudos realizados em diferentes países mostraram que cerca de $80 \%$ a $90 \%$ dos casos apresentam os primeiros sintomas entre o terceiro e $14^{\circ}$ dias (SCHRAMM et al., 1996).

O quadro clínico é dominado por espasmos musculares, rigidez e distúrbios autonômicos. Rigidez do pescoço, dor de garganta e dificuldade em abrir a boca são os primeiros sintomas. O espasmo do masseter causa o trismus (travamento da mandíbula), com os espasmos estendendo-se para os músculos faciais, o que causa a característica expressão facial denominada riso sardônico. Espasmos musculares podem levar à obstrução da laringe, bem como a uma diminuição da parede do tórax, resultando em comprometimento respiratório. O envolvimento dos músculos faciais causam uma extensão do pescoço e a rigidez do tronco pode levar ao opistótono. Dor nas costas, trismus, músculos rígidos e disfagia são comuns. O espasmo episódico tende a ser extremamente doloroso e afeta grupos musculares agonistas e antagonistas, podendo ser espontâneo ou sensível ao estímulo (disparado por estímulo tátil, visual, auditivo ou emocional). Esses espasmos podem aparecer convulsivamente e causar fraturas ou distensão de tendões em razão de sua intensidade (GOONETILLEKE e HARRIS, 2004).

O tétano maternal é aquele que ocorre durante a gravidez ou dentre seis semanas a partir do fim da mesma, seja pelo nascimento ou pelo aborto espontâneo ou provocado, e possui os mesmos fatores de risco e meios de prevenção que o tétano neonatal (ROPER et al., 2007) no qual os casos evoluem rapidamente para a morte, que ocorre dentro do período neonatal, isto é, o período que compreende os primeiros 28 dias após o nascimento (SCHRAMM et al., 1996).

\subsubsection{Prevenção, Profilaxia e Tratamento}

\subsubsection{Prevenção}

Milhares de vidas são salvas pela prática da vacinação, entretanto, em muitos países pobres o temor frente ao aparecimento de doenças preveníveis pela vacinação permanece. Anualmente, 27 milhões de crianças não são vacinadas contra doenças comuns na infância. Por conseguinte, cerca de dois a três milhões de crianças morrerão por doenças facilmente preveníveis e muitas mais adoecerão, faltarão às aulas e se tornarão parte de um ciclo vicioso que liga a saúde frágil à permanência da pobreza na idade adulta. Logo, a vacinação na 
infância é o principal fator no cuidado da saúde e traz imensos benefícios a baixo custo, já que uma criança pode ser imunizada de forma completa por aproximadamente USD \$30. Estão disponíveis vacinas para diversas doenças que acometem as crianças e seus familiares, como o sarampo, difteria, tétano, coqueluche (pertussis), pneumococos, hepatite B, Haemophilus influenzae tipo B e febre amarela. Assim, a imunização rotineira, além de instrumento essencial para o cuidado com a saúde, é o primeiro passo para se alcançar o desenvolvimento das comunidades e dos países (INTERNATIONAL FINANCE FACILITY FOR IMMUNISATION, 2007).

O tétano pode ser evitado através de práticas de higiene com o recém nascido, cuidados rápidos e adequados com ferimentos e aplicação de esquemas de imunização. A prevenção é realizada através da imunização ativa com a vacina $\mathrm{DTP}+\mathrm{Hib}$. O ciclo inicial de imunização consiste em três aplicações de vacina no primeiro ano de vida (aos 2, 4 e 6 meses), um reforço aos 15 meses e o segundo reforço (somente com DTP) entre 4 e 6 anos. Administra-se também uma dose de reforço com dT na época do ingresso no Ensino Fundamental, que é uma oportunidade estratégica para a atualização vacinal. Posteriormente, os reforços são recomendados a cada 10 anos. A imunização de gestantes é altamente recomendada para prevenir o tétano neonatal. Nesse caso, são administradas duas doses da vacina dT ou, na falta dessa, o TT, com intervalo de dois meses ou mais entre elas (mínimo de um mês). A primeira dose deve ser administrada o mais precocemente possível na gestação; a segunda, até vinte dias antes do parto. É importante que o serviço de saúde aplique as duas doses de vacina antes do parto. Ademais, para a adequada proteção da mãe e prevenção do tétano neonatal em gestação futura, é importante a administração de uma terceira dose, que deve ocorrer seis meses após a aplicação da segunda dose. No caso específico da gestante, que previamente recebeu uma ou duas doses de vacina contra o tétano (como DTP, DT, dT ou TT), deve-se aplicar duas ou uma dose de vacina dT ou, na falta dessa, da TT, a fim de completar três doses. Após a gestante ter sido vacinada com pelo menos três doses, aplica-se apenas uma dose de reforço após cinco anos da aplicação da última dose (SÃO PAULO, 2004).

\subsubsection{Profilaxia do Tétano após Ferimento}

Os ferimentos devem ser lavados com água e sabão e desbridamento profundo, se necessário, o mais rápido possível. $\mathrm{O}$ desbridamento do foco deve ser amplo, profundo e rigorosamente diário, visando bloquear a produção da toxina tetânica no local da ferida através da limpeza do ferimento com peróxido de hidrogênio (água oxigenada) ou 
permanganato de potássio. A finalidade é retirar as condições de anaerobiose, removendo todo o tecido desvitalizado e possível corpo estranho (pedaço de madeira, osso ou metal). A necessidade da vacinação contra o tétano, com ou sem imunização passiva, depende do tipo e condições do ferimento, assim como da história de imunização prévia [Tabela 3] (SÃO PAULO, 2004; CARVALHO, 2007).

Tabela 3 - Profilaxia do tétano após ferimento

\begin{tabular}{|c|c|c|c|c|}
\hline \multirow{2}{*}{$\begin{array}{l}\text { HISTÓRIA DE IMUNIZAÇÃO } \\
\text { CONTRA O TÉTANO }\end{array}$} & \multicolumn{2}{|c|}{$\begin{array}{l}\text { FERIMENTO LIMPO E } \\
\text { SUPERFICIAL }\end{array}$} & \multicolumn{2}{|c|}{ OUTROS FERIMENTOS } \\
\hline & VACINA & $\begin{array}{l}\text { IMUNIZAÇÃO } \\
\text { PASSIVA }\end{array}$ & VACINA & $\begin{array}{l}\text { IMUNIZAÇÃO } \\
\text { PASSIVA }\end{array}$ \\
\hline $\begin{array}{l}\text { INCERTA OU MENOS DE TRES } \\
\text { DOSES* }\end{array}$ & SIM & NÃO & SIM & SIM \\
\hline \multicolumn{5}{|l|}{ TRÊS DOSES OU MAIS } \\
\hline $\begin{array}{l}\text { ÚLTIMA DOSE HÁ MENOS DE } \\
\text { CINCO ANOS }\end{array}$ & NÃO & NÃO & NÃO & NÃO \\
\hline $\begin{array}{l}\text { ÚLTIMA DOSE ENTRE CINCO E } \\
\text { DEZ ANOS }\end{array}$ & NÃO & NÃO & SIM & NÃO \\
\hline $\begin{array}{l}\text { ÚLTIMA DOSE HÁ MAIS DE } \\
\text { DEZ ANOS }\end{array}$ & SIM & NÃO & SIM & NÃO \\
\hline
\end{tabular}

Vacina: para crianças abaixo de sete anos, tríplice (DTP) ou dupla para uso infantil (DT), se o componente pertussis for contra indicado; a partir dos sete anos, dupla para uso adulto (dT). Na falta desses produtos usar o Toxóide Tetânico (TT).

Imunização passiva: com soro antitetânico e teste prévio, na dose de 5.000 unidades, pela via intramuscular ou, preferentemente, com imunoglobulina humana antitetânica, na dose de 250 unidades pela via intramuscular; utilizar local diferente daquele no qual foi aplicada a vacina. Aproveitar a oportunidade para indicar a complementação do esquema de vacinação.

Original: CARVALHO, 2007.

\subsubsection{Tratamento}

No caso do tétano neonatal, o curativo do coto umbilical deve ser feito com peróxido de hidrogênio ou permanganato de potássio. O soro antitetânico (SAT), quando indicado para a neutralização da toxina tetânica circulante, é administrado intravenosamente na dosagem de 20.000 UI (independente do peso do paciente ou da gravidade do caso). Deve-se dar preferência ao uso da gamaglobulina antitetânica humana (soro homólogo), quando disponível, na dosagem de 3.000 a 6.000 UI (intravenosamente). O tratamento antimicrobiano é feito com o emprego de penicilina $\mathrm{G}$ cristalina e, em caso de alergia, pode-se optar pelo metronidazol. No tratamento das contraturas, pode-se utilizar drogas sedativas, podendo ser usado até curarizantes nos casos mais graves. Já o tratamento da hiperatividade simpática requer o uso de beta-bloqueadores, como o propranalol ou atenolol, nas taquicardias acima de 140 bpm (a 
dose deve ser avaliada de acordo com a resposta do paciente, com o devido cuidado no uso em idosos) (CARVALHO, 2007).

São recomendados os seguintes cuidados gerais com o paciente: isolamento em quarto fechado, escuro e silencioso (a fim de prevenir as contraturas desencadeadas por estímulos luminosos ou sonoros), remoção para UTI (na impossibilidade de controle das contraturas ou comprometimento da ventilação), enfermaria vigilante, dieta rigorosa, hidratação venosa e suporte calórico, medicação antiácida (prevenção de úlcera gástrica de estresse), atenção com complicações pulmonares, evitar uso de sondas vesicais (predispõe à infecção de trato urinário), realizar profilaxia de embolia pulmonar e avaliar a necessidade de tratar infecções secundárias com antibioticoterapia de amplo espectro (CARVALHO, 2007).

\subsection{Produção no Instituto Butantan}

\subsubsection{Produção da Anatoxina Tetânica}

A metodologia estabelecida no Instituto Butantan baseia-se no sistema lote-semente e se inicia com a obtenção da toxina tetânica através do processo fermentativo do C. tetani (cepa Harvard-Caracas) em meio Müeller modificado (LATHAM et al., 1962). Ao término do cultivo as células bacterianas são separadas por filtração tangencial. A toxina tetânica é concentrada por ultrafiltração molecular $(30 \mathrm{kDa})$ e, então, filtrada para esterilização (FRATELLI et al., 1993).

A destoxificação da toxina tetânica é feita pela ação do formaldeído e calor e, após esse processo e a liberação da prova de toxicidade específica, os lotes de anatoxina tetânica são concentrados de 6 a 10 vezes em sistema de ultrafiltração molecular (50 kDa) e diafiltração no mesmo sistema, usando solução salina tamponada pH 6,4 (para remoção do formaldeído residual) e então concentrada. Segue-se uma etapa de cromatografia (gel filtração) em resina Sephacryl S-200 HR. Ao produto purificado adiciona-se timerosal $(0,015 \mathrm{~g} \%)$ (PRADO et al., 1999).

Após filtração esterilizante, a anatoxina tetânica é amostrada pelo Serviço de Controle de Qualidade Interno para realização dos testes preconizados pela WHO (WORLD HEALTH ORGANIZATION, 1977) e Normas Nacionais (BRASIL, 1996, 1998). Os lotes aprovados são então destinados ao preparo das vacinas TT, dT, DT e DTP.

$\mathrm{Na}$ formulação final dessas vacinas utiliza-se no Instituto Butantan a concentração de $20 \mathrm{Lf} / \mathrm{mL}$ tanto para a anatoxina tetânica como para a anatoxina diftérica, com exceção da 
vacina dT, na qual a concentração da anatoxina diftérica é de $4 \mathrm{Lf} / \mathrm{mL}$. A vacina pertussis, na formulação da vacina DTP, é utilizada na concentração de $32 \mathrm{UOp} / \mathrm{mL}$. Utiliza-se como diluente solução salina tamponada pH 6,4 e como adjuvante o gel de hidróxido de alumínio $\mathrm{Al}(\mathrm{OH})_{3}$. O timerosal na concentração de $0,01 \mathrm{~g} \%$ é o conservante empregado.

São realizados todos os testes de controle de qualidade exigidos pelas normas vigentes, tais como testes microbiológicos, biológicos e físico-químicos, e o produto aprovado é distribuído em frascos-ampolas onde os testes de controle são repetidos.

O emprego de anatoxina diftérica em menor concentração na vacina dT deve-se ao fato da sensibilização ao toxóide diftérico que ocorre nos adultos. Entre dois meses e cinco anos de idade a ocorrência de alergia é relativamente rara. A partir dos sete anos, porém, essa situação se inverte, sendo bastante comum a reação alérgica, o que torna aconselhável o uso de toxóide diftérico mais diluído (DIAS DA SILVA, 1989).

\subsubsection{Produção do Soro Antitetânico}

No preparo dos antígenos destinados à hiperimunização dos eqüinos soroprodutores, a anatoxina tetânica (imunização de base) e a toxina tetânica (reimunização) são utilizadas.

A concentração dos antígenos empregados na imunização dos eqüinos é baseada no valor limite floculante (LYNG e BENTZON, 1987). Os antígenos são apresentados na forma fluida ou formulados com o adjuvante gel de hidróxido de alumínio $\mathrm{Al}(\mathrm{OH})_{3}$.

$\mathrm{Na}$ imunização de base, os eqüinos recebem onze doses de antígeno, sendo anatoxina tetânica da $1^{\mathrm{a}}$ a $7^{\mathrm{a}}$ dose, e toxina tetânica da $8^{\mathrm{a}}$ a $11^{\mathrm{a}}$ dose. Na reimunização recebem quatro doses de toxina tetânica.

Ao término da imunização, em ambos os casos, realiza-se uma sangria de prova para titulação dos anticorpos e seleção de cavalos com títulos iguais ou superiores a $400 \mathrm{UI} / \mathrm{mL}$. Os animais selecionados são sangrados (para produção) por três dias consecutivos, com intervalo de 24 horas entre cada sangria. O volume total de sangue extraído varia de 15 a 18 litros por animal. O sangue é coletado em presença de anticoagulante em sistema extrator formado por duas bolsas plásticas, interligadas através de mangueira flexível. Após 24 horas a $4{ }^{\circ} \mathrm{C}-5^{\circ} \mathrm{C}$, ocorre a separação do plasma, que é transferido para uma segunda bolsa, e as hemácias são ressuspensas em solução salina estéril e reinfudidas no animal (plasmaferese).

A purificação do plasma hiperimune é feita por precipitação com sulfato de amônio, fracionamento enzimático e termocoagulação. O sulfato de amônio modifica a solubilidade 
das proteínas no meio aquoso e separa as imunoglobulinas da albumina e das outras globulinas séricas. A digestão enzimática com pepsina cliva a imunoglobulina $\mathrm{G}$ em dois fragmentos: um maior, denominado fragmento $\mathrm{F}\left(\mathrm{ab}{ }^{\prime}\right)_{2}$ bivalente e com atividade de anticorpo; e um fragmento menor, conhecido como Fc, sensível ao calor, sem capacidade de combinação com o antígeno, mas com atividade de fixação de complemento pela via clássica. Com a perda do Fc, o anticorpo torna-se mais resistente ao calor, o que permite o seu aquecimento até $56{ }^{\circ} \mathrm{C}$. Desta forma, além de eliminar o $\mathrm{Fc}$, as proteínas termolábeis, como o fibrinogênio, são separadas por termocoagulação. O sulfato de amônio é removido do soro purificado por meio de diálise, utilizando sistema de ultrafiltros moleculares. O soro purificado é concentrado, cromatografado em resina de troca iônica (para remoção de aproximadamente $30 \%$ das imunoglobulinas inativas presentes no soro) e submetido a filtração esterilizante sendo, então, acondicionado em embalagem estéril à temperatura de $2{ }^{\circ} \mathrm{C}$ a $8{ }^{\circ} \mathrm{C}$ no aguardo dos testes de controle de qualidade. Uma vez aprovado em tais testes, o soro é diluído, adicionado de conservante (fenol), isotonizado, tem seu pH ajustado entre 6 e 7, sendo novamente submetido à filtração esterilizante. São realizados todos os testes de controle de qualidade exigidos pelas normas de saúde vigentes, tais como testes microbiológicos, biológicos e físico-químicos. O produto aprovado é distribuído em ampolas e os testes de controle são repetidos (CARDOSO et al., 2002).

Amostras representativas, tanto das vacinas como do soro antitetânico, depois de aprovadas pelo controle de qualidade interno, são enviadas ao laboratório de referência nacional para controle de qualidade - o Instituto Nacional de Controle de Qualidade em Saúde (INCQS) - que, após a realização dos testes de controle, emite o laudo final do produto para consumo.

\subsection{Adjuvantes}

A idéia original de que alguns materiais poderiam melhorar a resposta imune surgiu através do trabalho de William Coley, realizado em 1893, que usou produtos bacterianos para tratar pacientes com câncer (McKEE et al., 2007).

Os adjuvantes têm sido empregados para aumentar a resposta imune aos antígenos desde a década de 20, quando Gaston Ramon e colaboradores verificaram que cavalos desenvolveram um abscesso no local da inoculação do toxóide diftérico e geraram títulos elevados de anticorpos específicos (PETROVSKY e AGUILAR, 2004). Posteriormente, o mesmo grupo de pesquisadores demonstrou o aumento da resposta de antitoxina tetânica e 
diftérica após a inoculação desses produtos juntamente com outros componentes, tais como o ágar, tapioca, lecitina, óleo de amido e saponina (GUPTA et al., 1993; SCHIJNS, 2000; PETROVSKY e AGUILAR, 2004; McKEE et al., 2007).

Em 1926, Alexander Glenny e colaboradores demonstraram a atividade adjuvante dos compostos de alumínio com o toxóide diftérico adsorvido pelo alúmem (PETROVSKY e AGUILAR, 2004; LINDBLAD, 2004).

Em 1936, Freund desenvolveu uma emulsão de óleo mineral em água contendo micobactérias mortas, criando, desse modo, o mais potente dos adjuvantes conhecidos, o adjuvante completo de Freund (FCA). Apesar de ser um adjuvante padrão ouro, o FCA causa severas reações locais e é considerado muito tóxico para uso humano (PETROVSKY e AGUILAR, 2004; McKEE et al., 2007).

$\mathrm{Na}$ década de 50, Johnson e colaboradores demonstraram a atividade adjuvante do lipopolissacarídeo (LPS) de bactérias Gram-negativas e, a partir de então, o LPS destoxificado ou seus componentes correlatos, como o lipídeo A, passaram a ser estudados como adjuvante para uso humano. Em 1974, Ellouz e colaboradores identificaram o muramilpeptídeo (MDP) como componente micobacteriano com atividade adjuvante contida no FCA (ELLOUZ, et al., 1974; PETROVSKY e AGUILAR, 2004).

O objetivo da vacinação é a geração de uma forte resposta imune quando da administração de um antígeno hábil em promover proteção a longo prazo contra a infecção (PETROVSKY e AGUILAR, 2004). Nesses termos, a necessidade de adjuvantes é particularmente evidenciada para antígenos recombinantes altamente purificados e sintéticos que, em contrapartida, possuem a característica de baixa imunogenicidade, de modo geral (GUPTA et al., 1993; O’HAGAN et al., 2001; GIUDICE et al., 2002; O'HAGAN e RAPPUOLI, 2006). Entretanto, também são utilizados nas vacinas convencionalmente produzidas e, com seu uso, a quantidade de antígeno requerida para desencadear a resposta imune é diminuída, o que, conseqüentemente, reduz o custo referente à produção da vacina (GUPTA et al., 1993). Destaca-se que os adjuvantes são muitas vezes adicionados às vacinas para, além de reduzir a dose, diminuir a freqüência de injeções dos antígenos utilizados para a imunoprofilaxia de doenças infecciosas (MOTA, 1989).

Quimicamente os adjuvantes são um grupo de compostos estruturalmente heterogêneos, cujos componentes apresentam em comum apenas a característica funcional de induzir ou incrementar a resposta imune. Eles também são muito variáveis no tocante ao modo de como afetam o sistema imune, bem como do perfil de seus efeitos (GUPTA et al., 1993; SCHIJNS, 2000). 
Nesse sentido, o modo de ação dos adjuvantes pode ser assim resumido: 1) formação de depósito de antígeno no local da inoculação, onde o mesmo é lentamente liberado; 2) apresentação do antígeno às células imunocompetentes; 3) produção de diferentes linfocinas, tais como interleucinas e fator de necrose de tumor (GUPTA et al., 1993).

Ressalte-se que a ação de depósito eleva a magnitude da resposta imune porque o retardamento da eliminação do antígeno resulta em imbricação da resposta primária com a resposta secundária (MOTA, 1989).

Um adjuvante é qualquer substância que aumente a imunogenicidade de outras substâncias injetadas misturadas com ele e diferem das proteínas carreadoras por não formarem ligações estáveis com o imunógeno. Além disso, os adjuvantes são, em geral, necessários para as imunizações iniciais, enquanto os carreadores são necessários para desencadear não apenas a resposta primária ao hapteno, mas também as subseqüentes (JANEWAY JR. et al., 2007).

Os adjuvantes imunológicos foram originalmente descritos por Gaston Ramon como sendo substâncias que, quando usadas em combinação com um antígeno específico, produzem uma resposta imune mais vigorosa do que o antígeno sozinho. Essa definição abrange uma extensa classe de substâncias que, embora tenham surgido nos últimos anos como candidatas a adjuvantes e tenham sido inclusive testadas em humanos, não podem ser consideradas como tais. Os únicos adjuvantes admitidos para uso humano eram os alumínios baseados em sais minerais (genericamente denominados alúmen) (O’HAGAN et al., 2001; GIUDICE et al., 2002; O'HAGAN e RAPPUOLI, 2006). Entretanto, em 1997, na Europa, o adjuvante MF59 foi licenciado para uso em humanos associado à vacina contra a influenza (GIUDICE et al., 2002; McKEE et al., 2007). Ressalte-se o teste clínico realizado empregando o MF59 como adjuvante de vacinas, registrado em mais de vinte países como uma vacina contra a influenza eficaz e bem tolerada para uso em idosos. Demonstrou-se, ainda, que o MF59 pode ser seguramente administrado com vários antígenos em grupos de idades diversas, incluindo a população pediátrica (O’HAGAN e RAPPUOLI, 2006; SINGH et al., 2006).

\subsubsection{Função}

Os adjuvantes geralmente são empregados para as seguintes finalidades: 1) aumentar a imunogenicidade de um antígeno recombinante ou altamente purificado; 2) reduzir a quantidade de antígenos ou o número de imunizações necessárias para uma imunidade protetora; 3) aumentar a eficácia de uma vacina em recém-nascidos, idosos ou pessoas 
comprometidas; 4) atuar como sistema de fornecimento de antígeno para esse ser absorvido por mucosas (PETROVSKY e AGUILAR, 2004).

A maioria das vacinas existentes possui, em geral, duas características: com raras exceções, a via de administração é parenteral, sendo formuladas em associação com adjuvantes denominados de estimuladores da imunogenicidade (GUPTA et al., 1993; GIUDICE et al., 2002).

Além disso, saliente-se que nem todos adjuvantes reagem do mesmo modo com todas as vacinas, como por exemplo, os sais de alumínio que não foram adjuvantes eficientes para a vacina contra a influenza, para algumas vacinas conjugadas de Toxoíde Tetânico-Hib, assim como para antígenos recombinantes e peptídeos (GIUDICE et al., 2002).

Outros fatores importantes que podem limitar a adjuvanticidade são as vias de administração das vacinas, as respostas imunológicas a serem alcançadas, a eficácia a ser atingida em humanos e animais e a reatogenicidade dos compostos usados como adjuvantes. Pode-se citar como exemplo da importância da via de administração os estudos realizados com a vacina contra a influenza preparada com o adjuvante MF59, que demonstraram que a imunização por via parenteral é mais eficaz do que aquela realizada através de mucosas (GIUDICE et al., 2002).

\subsubsection{Classificação}

Esforços têm sido empreendidos para agrupar os adjuvantes em categorias a fim de facilitar a seleção dos mesmos, pois se trata de difícil tarefa em razão dos múltiplos efeitos biológicos de muitos dos adjuvantes. Entretanto, esse estudo pode ter utilidade, pois fornece uma visão dos tipos de imunoestimuladores disponíveis (ALVING, 2002).

Uma das possibilidades de classificar os adjuvantes seria de acordo com a origem, mecanismo de ação e propriedades físico-químicas (MARCIANI, 2003; PETROVSKY e AGUILAR, 2004).

Edelman e Tackett (1990) propuseram uma prática categorização de diferentes tipos de imunoestimuladores que foram assim denominados: 1) adjuvantes per se (imunoestimulante ativo); 2) carreadores; e, 3) veículos. Estão incluídos na categoria adjuvantes per se os sais de alumínio, saponinas, muramil - di e tripeptídeo, monofosforil lipídeo A, Bordetella pertussis, citocinas e muitos outros. Já os carreadores incluem os toxóides bacterianos, ácidos graxos e vetores vivos. A categoria veículos abrange as emulsões de óleo mineral (p. ex. adjuvante incompleto de Freund), emulsões de óleo biodegradável (p. ex. emulsões contendo óleo de 
amendoim, esqualeno ou esqualano), bloqueadores não iônicos copolímeros surfactantes, lipossomos e microesferas de polímeros biodegradáveis (ALVING, 2002).

Cox e Coulter (1997) propuseram outra categorização para os adjuvantes, baseando-se em cinco potenciais modos de ação: 1) imunomodulação (modificação da rede de citocinas); 2) apresentação; 3) indução de CTL (linfócitos T citotóxicos); 4) direcionamento; e, 5) geração de depósito (ALVING, 2002).

Os adjuvantes também são classificados de acordo com a via de administração (parenteral ou através de mucosas) ou conforme: sais de alúmem e outros adjuvantes minerais; agentes tensoativos; derivados bacterianos; veículos e lentos liberadores de materiais ou citocinas. Um sistema de classificação bem aceito divide os adjuvantes nos seguintes grupos: adjuvantes em base de gel; agentes tensoativos, produtos bacterianos; emulsões oleosas, adjuvantes particulados, proteínas de fusão ou lipopeptídeos (PETROVSKY e AGUILAR, 2004).

Entretanto, a classificação mais aceita fundamenta-se no modo de ação do adjuvante, que pode ser imunoestimulante ou baseado em um sistema de fornecimento antigênico (ADS - antigen delivery system). Os imunoestimulantes referem-se à propriedade que esse tipo de adjuvante possui em modificar a rede de citocinas, podendo resultar em um aumento da regulação de todo sistema imunológico, porém, com maior freqüência, há a predominância de alguma citocina em detrimento de outras. Os adjuvantes que atuam como sistema de fornecimento (ADS) são de natureza particulada. Diferentemente de muitos antígenos solúveis, que muitas vezes são ignorados pelo sistema imune, as partículas são estranhas e também nocivas (COX e COUTER, 1997; MARCIANI, 2003).

\subsubsection{Principais Tipos}

Os adjuvantes mais utilizados são: 1) adjuvante incompleto de Freund (FIA) (emulsão óleo em água); 2) adjuvante completo de Freund (emulsão óleo em água com micobactérias mortas); 3) adjuvante de Freund com MDP (emulsão óleo em água com muramildipeptídeo, um constituinte de micobactérias); 4) alúmen - hidróxido de alumínio (gel de hidróxido de alumínio); 5) alúmen mais $B$. pertussis (gel de hidróxido de alumínio com B. pertussis); e, 6) complexos imuno-estimuladores (ISCOMs) (matriz de QuilA contendo proteína de vírus) (JANEWAY JR. et al., 2007).

O QuilA é um extrato solúvel da árvore Quillaja saponaria que contém múltiplas saponinas. Embora o QuilA seja altamente efetivo, é muito tóxico para uso em humanos 
causando severas reações locais, granulomas e hemólises. O QS21 (Quillaja saponaria fração 21) é menos tóxico que a fração purificada de QuilA (McKEE et al., 2007).

Destaca-se que o LPS, apesar de ser um poderoso adjuvante, é muito tóxico para ser utilizado com segurança em humanos. Entretanto, a hidrólise do bioativo lipídeo A em LPS resulta em uma molécula denominada monofosforil lipídeo A, que é um adjuvante com toxicidade reduzida quando comparado ao lipídeo A (McKEE et al., 2007).

Outro tipo de adjuvante óleo em água é o MF59, que consiste em uma emulsão opalescente, cujo óleo utilizado na preparação é o esqualeno, o qual é biodegradável e biocompatível (GIUDICE et al., 2002; O’HAGAN e RAPPUOLI, 2006). Também são conhecidas as emulsões óleo em água Montanide, Adjuvante 65 e Lipovante (PETROVSKY e AGUILAR, 2004).

\subsubsection{Sais de Alumínio}

Bilhões de doses de vacinas com adjuvantes de alumínio têm sido administradas anualmente, sendo, até o momento, os adjuvantes mais comumente utilizados tanto em vacinas humanas como veterinárias. De modo geral, os adjuvantes de alumínio são considerados seguros quando usados de acordo com os critérios dos programas atuais de vacinação. Em humanos os adjuvantes de alumínio são utilizados nas vacinas contra o tétano, difteria e pertussis, como parte dos programas de vacinação de crianças, por aproximadamente 50 anos. Os adjuvantes de alumínio também têm sido introduzidos nas vacinas contra hepatite A e hepatite B. Outras vacinas adsorvidas pelo alumínio, como por exemplo contra o antrax, estão disponíveis para grupos de risco. $\mathrm{Na}$ medicina veterinária os adjuvantes de alumínio estão sendo utilizados na formulação de um grande número de vacinas contra doenças bacterianas e virais e na tentativa de produzir vacinas contra parasitas (LINDBLAD, 2004).

Os sais de alumínio são comumente adicionados a diversas vacinas em forma de alúmem (sulfato de alumínio e potássio), sulfato de alumínio ou hidróxido de alumínio, sendo que este último parece ser o mais eficaz dos três, especialmente quanto à duração da imunização primária (JEFFERSON et al., 2004).

Ressalte-se que o termo alúmem é usado para descrever ambos compostos de alumínio, gel de hidróxido de alumínio e gel de fosfato de alumínio, mas essa terminologia é incorreta. $\mathrm{O}$ alúmem de potássio, $\mathrm{KAl}\left(\mathrm{SO}_{4}\right)_{2} \cdot 12 \mathrm{H}_{2} \mathrm{O}$, está de acordo com a definição química de um 
alúmem, porém, o hidróxido de alumínio e o fosfato de alumínio não estão (LINDBLAD, 2004).

Não há evidências claras de que a adsorção em adjuvantes de alumínio gere o aumento ou diminuição da reatogenicidade da vacina. Entretanto, Butler e colaboradores (1969) concluíram que a adsorção em hidróxido de alumínio (Alhidrogel ${ }^{\circledR}$ ) reduz significativamente os efeitos colaterais das vacinas difteria-tétano-pertussis. A afinidade de ligação do LPS ao hidróxido de alumínio é bem estabelecida e maior do que a ligação ao fosfato de alumínio. Contudo, os efeitos colaterais seguidos da vacinação contendo adjuvantes podem ser atribuídos aos preservativos da vacina, como por exemplo, o timerosal, betapropiolactona ou formaldeído. Não há dúvidas de que os adjuvantes de alumínio são eficientes e possuem um grande número de aplicações em vacinas usadas tanto na profilaxia humana como na veterinária, apresentando assim poucos problemas. Além disso, eles são relativamente baratos, o que, embora não seja importante sob o ponto de vista científico, apresenta grande relevância nos programas de vacinação dos países em desenvolvimento, onde o orçamento é limitado (LINDBLAD, 2004).

Entretanto, em uma recente avaliação da segurança das vacinas adsorvidas pelo alúmem, concluiu-se definitivamente serem eles seguros para uso difundido. Todavia, os adjuvantes baseados em alúmem não são vistos como adequados ou suficientemente potentes para o desenvolvimento de novas vacinas, as quais necessitarão de uma complexa combinação de produtos com vários tipos de antígenos a serem incluídos, que podem ser: proteína polissacarídica conjugada, proteínas recombinantes e toxoídes tradicionais. Além disso, o montante da dose de alumínio aceitável para vacinas humanas limita o seu potencial de reunir vários antígenos na mesma fórmula (entre 1,0 a 1,5 mg/vacinação) (SINGH et al., 2006).

\subsubsection{Mecanismo de Ação}

Os adjuvantes podem aumentar a imunogenicidade de duas formas distintas. Primeiramente, convertem antígenos protéicos solúveis em material particulado, facilmente ingerido por células apresentadoras de antígeno, como os macrófagos. Por exemplo, o antígeno pode ser absorvido por partículas do adjuvante (como o alúmen), ou particulado por emulsificação em óleos minerais, ou incorporado em partículas coloidais de ISCOMs (immune stimulatory complexes), sendo esse último complexos imunoestimuladores do antígeno, mantidos no interior de uma matriz lipídica, que age como um adjuvante e possibilita a internalização do antígeno no citoplasma após a fusão do lipídeo com a 
membrana citoplasmática. Isso aumenta um pouco a imunogenicidade, mas esses adjuvantes são relativamente fracos, salvo se associados a bactérias ou componentes de bactérias. Esses componentes bacterianos são a segunda maneira pela qual os adjuvantes podem aumentar a imunogenicidade e, embora sua exata contribuição nesse aumento seja desconhecida, eles certamente são os componentes mais importantes de um adjuvante. Os produtos microbianos podem sinalizar para que os macrófagos ou células dendríticas se tornem células apresentadoras de antígeno efetivas. Um dos seus efeitos é induzir a produção de citocinas inflamatórias e potentes respostas inflamatórias locais; tal efeito provavelmente é intrínseco à sua ação em aumentar as respostas, mas impossibilita seu uso em humanos. Todavia, algumas vacinas humanas contêm antígenos microbianos que também podem atuar como bons adjuvantes. Por exemplo, a bactéria $B$. pertussis, agente causador da coqueluche, é usada tanto como antígeno quanto como adjuvante na vacina tríplice bacteriana (DTP), que é aplicada aos lactentes no primeiro ano de vida contra essas doenças (JANEWAY JR. et al., 2007).

Antígenos purificados não são fortemente imunogênicos por si mesmos e a maioria das vacinas acelulares requer a adição de adjuvantes. Pode-se citar, por exemplo, as vacinas de Toxóide Tetânico (TT, dT, DT, DTP e DTP + Hib) que freqüentemente contêm sais de alumínio, que se ligam polivalentemente ao toxóide por interações iônicas e estimulam seletivamente respostas de anticorpos (FIKRIG et al., 2007).

Muitos adjuvantes importantes são constituintes estéreis da bactéria, particularmente das suas paredes celulares. Por exemplo, o adjuvante completo de Freund, amplamente utilizado em modelos experimentais para aumentar as respostas humorais, é uma emulsão em água e óleo que contém micobactérias mortas. Um complexo glicolipídeo, muramildipeptídeo, que pode ser extraído da parede celular micobacteriana ou sintetizado, apresenta atividade adjuvante semelhante à micobactéria morta. Outros adjuvantes bacterianos incluem a B. pertussis morta, polissacarídeos bacterianos, proteínas bacterianas de choque térmico e DNA bacteriano. A maioria desses adjuvantes causa uma inflamação pronunciada e não é adequada para uso em vacinas humanas (FIKRIG et al., 2007).

Acredita-se que a maioria dos adjuvantes, senão todos, atuam nas células apresentadoras de antígenos, especialmente nas células dendríticas, refletindo a importância dessas na indução das respostas imunológicas. Sabe-se que as células dendríticas estão amplamente distribuídas no organismo, atuando como sentinelas para detectar patógenos potenciais nas suas vias de entrada. Essas células dendríticas teciduais capturam os antígenos do ambiente por fagocitose e macropinocitose e são, então, induzidas para responder à presença da infecção, migrando para dentro do tecido linfóide e apresentando esses antígenos 
às células $T$. As células dendríticas parecem detectar a presença de patógenos de duas principais maneiras. A primeira via é direta e segue a ligação e a ativação de receptores pelos microrganismos invasores. Esses incluem os receptores do sistema do complemento, os receptores semelhantes ao Toll (TLRS) e outros receptores de reconhecimento de padrões do sistema imune inato (FIKRIG et al., 2007).

O papel dos TLRS é ativar os fagócitos e as células dendríticas a responder aos patógenos pela secreção de quimiocinas e citocinas e pela expressão de moléculas coestimuladoras necessárias para a ativação da resposta imune adaptativa (BEUTLER et al., 2007).

A descoberta de que os efeitos de muitos adjuvantes são mediados pela ativação dos TLRS das células dendríticas permitiu o desenvolvimento racional de novos adjuvantes para a terapia de vacinas. O LPS é um componente da parede celular de bactérias Gram-negativas. Possui efeito adjuvante, mas é limitado por sua toxicidade. A injeção de uma pequena quantidade de LPS pode induzir o estado de choque e inflamação sistêmica que mimetiza a sepse Gram-negativa. A questão-chave é saber se o efeito adjuvante do LPS pode ser separado dos seus efeitos tóxicos. Um derivado do LPS, monofosforil lipídeo A, atinge parcialmente esse requisito, retendo os efeitos adjuvantes, mas associado a uma toxicidade muito mais baixa do que o LPS parental. Tanto o LPS quanto o monofosforil lipídeo A são ligantes do TLR-4, que parece ser o receptor mais importante na mediação dos efeitos adjuvantes do LPS e de seus derivados. Outros adjuvantes utilizam outros TLRs. O CpG não metilado do DNA se liga ao TLR-9; os componentes lipoprotéicos de muitas bactérias Gram-positivas se ligam ao TLR-2; e o dipeptídeo muramil se liga a NOD2, que está relacionado ao reconhecimento intracelular de bactérias (FIKRIG et al., 2007). Há hipótese de que o NOD2 possa ser um receptor intracelular para o LPS bacteriano (COFFMAN et al., 2007).

Estas descobertas transformaram o entendimento sobre os mecanismos de ação dos adjuvantes. As células dendríticas, ao serem ativadas por meio da ligação dos TLRs, respondem secretando citocinas e expressando moléculas co-estimuladoras, as quais, por sua vez, estimulam a ativação e a diferenciação de células $\mathrm{T}$ antígeno-específicas. Entretanto, ainda existem algumas questões a serem desvendadas no que diz respeito à eficácia e à toxicidade dos adjuvantes, essencialmente em razão dos seus efeitos farmacológicos e toxicológicos serem mediados de maneira idêntica. A função fisiológica dos TLRs consiste em estimular uma resposta inflamatória e imune contra a infecção. A ligação farmacológica desses receptores pelos adjuvantes no contexto da vacinação leva a um processo refinado entre o estímulo benéfico da imunidade e a inflamação prejudicial (FIKRIG et al., 2007). 
O segundo mecanismo de estímulo das células dendríticas pelos microrganismos invasores é indireto e envolve sua ativação por sinais de citocinas derivadas da resposta inflamatória induzida pela infecção. As citocinas, como o GM-CSF, são particularmente efetivas na ativação das células dendríticas, induzindo a expressão de sinais co-estimuladores e, no contexto da infecção viral, as células dendríticas também expresssam IFN- $\alpha$ e IL-12 (FIKRIG et al., 2007).

Os adjuvantes enganam o sistema imune como se houvesse uma infecção ativa e, já que existem várias classes de agentes infecciosos que estimulam vários tipos de resposta imune, diferentes adjuvantes podem promover diferentes tipos de resposta, como por exemplo, uma resposta inflamatória $\mathrm{T}_{\mathrm{H}} 1$ ou uma resposta dominada por anticorpos. Alguns adjuvantes, por exemplo, a toxina pertussis, a toxina cólera e a enterotoxina termolábil de E. coli, estimulam respostas imunes nas mucosas, as quais são particularmente importantes na defesa contra organismos cujas portas de entrada são os tratos digestivo ou respiratório (FIKRIG et al., 2007).

\subsubsection{Efeitos Adversos}

A hiperativação da resposta imune pelos adjuvantes pode ser acompanhada por reações adversas envolvendo diversos mecanismos do sistema imune, mas o perfil geral dos efeitos adversos pelo uso dos adjuvantes envolve qualquer efeito adverso farmacológico causado pelo adjuvante, seja envolvendo o sistema imune ou parâmetros fisiológicos alheios a ele (GUPTA et al., 1993).

Os benefícios decorrentes da incorporação de um adjuvante na formulação de uma vacina devem ser balanceados com o risco das reações adversas, as quais podem ser locais ou sistêmicas. As reações locais podem ser: dor, inflamação local, inchaço, necrose no local da injeção, linfoadenopatia e granulomas (úlceras e a geração de abscessos estéreis). Quanto às reações sistêmicas, pode-se citar: náuseas, febre, artrite, uveíte, eosinofilia, alergia, anafilaxia, toxicidade em órgãos específicos (fígado e pulmão) e imunotoxicidade (p. ex. liberação de citocinas imunossupressoras ou doenças auto-imunes) (PETROVSKY e AGUILAR, 2004). Os sais de alumínio, embora empregados como adjuvantes de vacinas por décadas, têm sido responsabilizado por causar nódulos, granulomas, eritemas e fadiga muscular (JEFFERSON et al., 2004).

Não há provas de que os adjuvantes de alumínio são imunogênicos e ajam como haptenos, já que eles são improváveis de causar reações imunes complexas e dolorosas, além 
das reações de hipersensibilidade de contato, que são raras. Os adjuvantes de alumínio não são pirogênicos e não há evidência que sejam carcinogênicos ou teratogênicos. Por outro lado, o hidróxido de alumínio apresenta afinidade de ligação a endotoxinas, que podem reduzir a reatogenicidade de algumas vacinas adsorvidas contendo, por exemplo, o residual LPS (LIMDBLAD, 2004).

Diante do exposto, pode-se concluir que para um adjuvante ser considerado modelo deve apresentar os seguintes requisitos: ser biodegradável, simples de fabricar e com componentes disponíveis para diversos antígenos vacinais; conter, em um único frasco/seringa, tanto adjuvantes como antígenos; apresentar baixo custo de produção; a inclusão do adjuvante não pode causar impacto significante no custo de fabricação da vacina; deve existir a possibilidade de utilização com diferentes tipos de vacinas e vias de administração (mucosa e oral); induzir o mínimo de reações locais ou sistêmicas após a administração; induzir resposta imune de longa duração; não induzir doenças auto-imunes e promover uma apropriada resposta imune celular ou humoral (O'HAGAN et al., 1997; PETROVSKY e AGUILAR, 2004).

\subsection{Monometoxi-polietilenoglicol (mPEG)}

Desde a década de 70 muitos artigos que tratam da modificação química de proteínas por conjugação com macromoléculas sintéticas, como os derivados do polietilenoglicol (PEG), têm sido publicados. O objetivo da modificação das proteínas inclui a redução da imunoreatividade ou imunogenicidade e a supressão da Ig E produzida nos processos médicos (INADA et al., 1986; INADA et al., 1995; KODERA et al., 1998).

Mais de uma centena de tipos de proteínas foram modificadas pelo mPEG ativado e as proteínas modificadas por essa reação têm sido extensivamente estudadas em relação à terapia de várias doenças, tais como o câncer, inflamação, auto-imunidade, alergia e outras (KODERA et al., 1998).

As razões do interesse na conjugação com o mPEG ativado residem nas características do PEG, tais como ausência de imunogenicidade e toxicidade, alta solubilidade tanto na água como em diversos solventes orgânicos, disponibilidade e a aprovação do US Food and Drug Administration (FDA) para uso humano (PASUT et al., 2007).

Alguns problemas podem ser solucionados pelo uso do PEG modificado conjugado à proteína. Em 1991, a enzima adenosina deaminase (PEG-ADA) foi a primeira proteína conjugada ao PEG a ser aprovada pelo FDA, sendo usada no tratamento de crianças com alta 
deficiência de ADA, que causa a síndrome de imunodeficiência aguda (SSID) (INADA et al., 1995; KODERA et al., 1998). Posteriormente, o FDA autorizou a forma modificada da asparaginase $\left(\right.$ Oncaspar $^{\circledR}$ ) para uso humano (KOZLOWSKI e HARRIS, 2001), que é particularmente efetiva em certos tipos de terapia anticancerígena (SOARES et al., 2002).

A fórmula linear do PEG apresenta a seguinte estrutura (ROBERTS et al., 2002):

$$
\mathrm{HO}-\left(\mathrm{CH}_{2} \mathrm{CH}_{2} \mathrm{O}\right)_{\mathrm{n}}-\mathrm{CH}_{2} \mathrm{CH}_{2}-\mathrm{OH}
$$

A importância da química e qualidade dos reagentes PEG ativados para modificação de peptídeos e proteínas somente foi percebida nos últimos anos, quando os produtos PEGconjugados já se encontravam em estudos clínicos. Os primeiros produtos $\mathrm{PEG}$ conjugados à proteína que foram introduzidos no mercado são o Adagen ${ }^{\circledR}$ e Oncaspar ${ }^{\circledR}$, desenvolvidos com a primeira geração química de PEG ativado (ROBERTS et al., 2002; VERONESE e PASUT, 2005). O Oncaspar ${ }^{\circledR}$ (PEG-asparaginase) é indicado para o tratamento de leucemia limfoblástica aguda e outras doenças linfóides malignas, já o Adagen ${ }^{\circledR}$ (PEG-adenosina deaminase) é utilizado no tratamento da síndrome de imunodeficência severa (VERONESE e PASUT, 2005). A segunda geração de moléculas ativadas de PEG foi idealizada para evitar os problemas químicos ocorridos com a primeira geração, pelas impurezas do $\mathrm{PEG}$, restrição à baixa massa molecular do mPEG, ligações instáveis e falta de seletividade na modificação (ROBERTS et al., 2002).

Atualmente, os requerimentos para aprovação de novos conjugados são mais exigentes e a caracterização de cada isômero, quando possível, é obrigatória. São exemplos dessas novas exigências os $\alpha-2$ interferon conjugados, Pegasys ${ }^{\circledR}$ e PEG-Intron ${ }^{\circledR}$ (indicados para casos de hepatite e infecção por vírus $\mathrm{C}$ da hepatite extra hepática) para os quais quase todos os locais de ligação na seqüência primária foram estabelecidos (VERONESE e PASUT, 2005; PASUT e VERONESE, 2007).

\subsubsection{Propriedades do PEG Ativado}

São denominados polietilienoglicol os polímeros com mais de três etilenos. Possuem uma apresentação que varia entre um líquido translúcido e flocos hidrossolúveis (KODERA et al., 1998). O PEG é formado por repetidas sub unidades de óxido de etileno, cujo número é representado por um número inteiro $n$. Cada resíduo de óxido de etileno possui massa 
molecular de $44 \mathrm{Da}$, sendo que $n$ x 44 Da representa o número médio da massa molecular da cadeia do PEG, e seus dois grupos hidroxi terminal podem ser quimicamente ativados (BAILON e BERTHOLD, 1998).

Os polietilenoglicóis são solúveis em água, gordurosos e não volatizam. São empregados na indústria como lubrificantes, veículos medicamentosos, solventes, ligantes e insumos nas indústrias de borracha, cosméticos, agricultura, têxtil, papel, petróleo, alimento, farmacêutica, entre outras (KODERA et al., 1998).

A massa molecular do PEG ativado, comumente utilizada para fins biomédicos e biotecnológicos, está entre $100 \mathrm{Da}$ e 20.000 Da (KODERA et al., 1998). Independentemente da massa molecular, são todos metoxilados em uma das extremidades, daí a sigla empregada mPEG- $R$, na qual $R$ pode representar uma $\mathrm{OH}$ ou $\mathrm{COOH}$, conforme o caso (VERONESE, 2001; KOZLOWSKI e HARRIS, 2001; ROBERTS et al., 2002).

O monometoxi-poletilenoglicol (mPEG) apresenta a seguinte estrutura (ROBERTS et al., 2002):

$$
\mathrm{CH}_{3} \mathrm{O}-\left(\mathrm{CH}_{2} \mathrm{CH}_{2} \mathrm{O}\right)_{\mathrm{n}}-\mathrm{CH}_{2} \mathrm{CH}_{2}-\mathrm{OH}
$$

Ademais, ressalte-se as seguintes propriedades de interesse: 1) o PEG apresenta comportamento anfipático - solúvel em água, tolueno, 1,1,1-tricloroetano e benzeno, e insolúvel em éter etílico e hidrocarbonetos alifáticos; 2) não tóxicos com massa molecular acima de $1.000 \mathrm{Da}$, sendo que o PEG com massa molecular de $4.000 \mathrm{Da}$ pode ser seguramente administrado por via endovenosa em solução de $10 \%$ para ratos, cobaias, coelhos e macacos até a dose de $16 \mathrm{~g} / \mathrm{Kg}$ de peso corporal (aprovado pelo FDA para consumo interno); 3) o PEG apresenta baixa imunogenicidade; 4) o PEG causa fusão celular quando em altas concentrações; 5) o PEG forma sistema de duas fases com solução aquosa e outra macromolécula, tal como o dextran ou solução de sal concentrada; 6) o PEG pode ser utilizado para precipitar proteínas e ácidos nucléicos; 7) o PEG solubiliza enzimas e substâncias bioativas em solventes orgânicos ou em solução aquosa; 8) o mPEG gera proteínas não imunogênicas e tolerogênicas; 9) prolonga o tempo para eliminação da proteína conjugada ao PEG ativado in vivo; 10) o mPEG ativado estabiliza a função fisiológica de proteínas e substâncias bioativas; 11) o mPEG ativado ajusta a farmacocinética de várias drogas; e, 12) o PEG separa macromoléculas biológicas, membranas, particulados celulares e células (KODERA et al., 1998). Saliente-se que enzimas modificadas pelo PEG ativado 
possuem clearence maior que 24 horas sendo, dessa forma, estendido o tempo para eliminação da proteína conjugada (SOARES et al., 2002).

A modificação pelo PEG também pode reduzir a imunogenicidade de enzimas, anticorpos, toxinas e proteínas recombinante humana, que podem induzir resposta imune humoral (TSAI et al., 2001).

As proteínas PEGladas também demonstram distribuição modificada no corpo e, quando injetadas subcutaneamente, apresentam absorção sanguínea que é dependente da massa molecular do mPEG. Ademais, as proteínas modificadas têm estabilidade assegurada durante a estocagem (KOZLOWSKI e HARRIS, 2001).

\subsubsection{Ativação do PEG para Uso na Conjugação de Proteínas}

Proteínas e enzimas podem ser modificadas por uma série de derivados do PEG [Figura 14]. Essas modificações são freqüentemente realizadas a partir do monometoxipolietilenoglicol (mPEG), o qual possui um grupo hidroxila na parte final da molécula controlado pela manipulação (KODERA et al., 1998).

A reação mais comum de PEGlação envolve a ativação eletrofílica do PEG e o grupo $\varepsilon$-amino da lisina ou de proteínas com grupamento amino $\mathrm{N}$-terminal, embora também possam ser ativados por outros grupos funcionais da superfície da proteína (BAILON e BERTHOLD, 1998; KOZLOWSKI e HARRIS, 2001).

\subsubsection{PEG succinimidil}

O mPEG possui um grupo carboxil terminal, o qual pode ser usado no preparo de ésters ativos do polímero, assim como se ligar diretamente à moléculas de importância. $\mathrm{O}$ N-hidroxisuccinimidil (NHS) éster de PEG pode reagir diretamente com grupos aminas das moléculas de proteína em $\mathrm{pH}$ entre 7,0 e 9,0. Um dos métodos mais práticos para introduzir grupos carboxil nos grupo hidroxil do PEG é a reação com o anidrido succínico, que é ativado como PEG succinimidil succinato (ABUCHOWSKI et al., 1984). 


\subsubsection{PEG-succinimidil carbonato}

Em 1992, Zalipsky e colaboradores desenvolveram um novo procedimento para ativação do PEG, por meio do qual o grupo hidroxil do $\mathrm{mPEG}$ reagiu com fosgene seguido de ativação com N-hidroxisuccinimidil (NHS). O produto resultante PEG-succinimidil carbonato, reage com os grupos aminos das proteínas em $\mathrm{pH}$ entre 7,0 e 10,0.

\subsubsection{PEG-aminoácidos}

Yamasaki e colaboradores (1988) prepararam alguns aminoácidos ligados ao PEG. O mPEG ácido(s) foi introduzido no grupo $\alpha$-amino da norleucina ou grupos $\alpha$ - e $\varepsilon$-amino de lisina. Através de hidrólise ácida introduziu-se um grupamento carboxil por meio da ativação do N-hidroxisuccinimidil (NHS).

\subsubsection{PEG-triazina}

Na apresentação PEG-triazina o cloreto cianúrico reage com o álcool primário do PEG tornando-o ativado na forma $\mathrm{PEG}_{1}$ [2-(O-metoxipolietilenoglicol)-6-cloro-s-triazina] ou $\mathrm{PEG}_{2}$ [2,4-bis(O-metoxipolietilenoglicol)-6-cloro-s-triazina], e um dos cloros do anel de triazina promove a interação com a proteína (INADA et al., 1995). Tanto o $\mathrm{PEG}_{1}$ como o $\mathrm{PEG}_{2}$ podem ser usados para subseqüentes reações com os grupos aminos das proteínas em $\mathrm{pH}$ entre 8,0 e 9,0 e pH entre 9,5 e 10,0, respectivamente (KODERA et al, 1998).

\subsubsection{PEG-multivalente em Forma de Pente Achatado}

O PEG-multivalente em forma de pente achatado possui aros de polímeros de PEG e anidrido maléico, cuja massa molecular pode atingir até $100.000 \mathrm{Da}$. Essa forma modificada possui uma propriedade única: encobrir a molécula da proteína e/ou trocar um grupo aniônico (-COOH) da superfície da molécula protéica (KODERA et al., 1992). 


\subsubsection{Outros Derivados de PEG}

Além das modificações de grupos aminas com derivados do PEG, várias estratégias para modificação de proteínas têm sido analisadas. Uma delas diz respeito aos derivados heterofuncionais de PEG, que apresentam um terminal hidroxil para cada grupo específico podendo reagir com a amina terminal e outro grupo com a carboxila terminal da proteína (NAGASAKI et al., 1995).

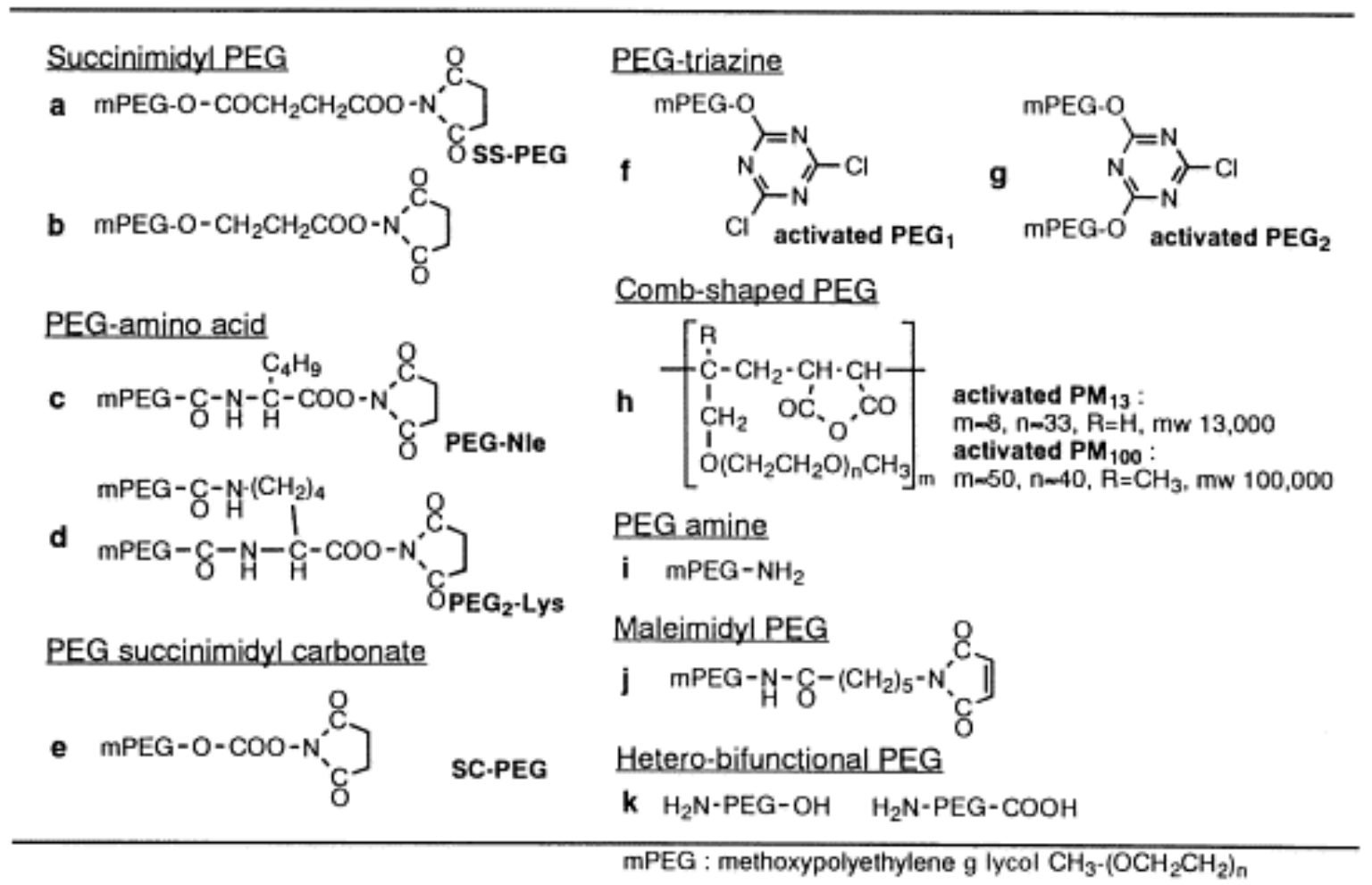

Figura 14 - Derivados do polietilenoglicol (PEG).

Figura original: KODERA et al, 1998.

\subsubsection{Parâmetros para Reação de PEGlação}

Os fatores que mais interferem na reação de PEGlação são: $\mathrm{pH}$, massa molecular da proteína a ser conjugada ao $\mathrm{PEG}$, concentração protéica, tempo e temperatura de reação (BAILON e BERTHOLD, 1998). 


\subsubsection{Caracterização do mPEG Conjugado}

O desenvolvimento da tecnologia de PEGlação faz com que a análise do PEGproteínas seja imprescindível à pesquisa laboratorial e ao controle de qualidade do produto industrial. Conforme muitas reações químicas, a PEGlação também gera a distribuição de produtos com diferentes números de PEG por molécula de proteína e várias posições de ligação. A mistura também contém proteína não modificada e PEG não reagido, o que também pode interferir na análise e caracterização do produto (ZHENG et al., 2007).

Uma das dificuldades consiste em precisar o número de cadeias de polímero ligadas ao peptídeo ou proteínas. O PEG é transparente e não fluorescente sendo, portanto, indetectável, além de não liberar produtos facilmente quantificados pela hidrólise. A reação colorimétrica do PEG com o iodo pode ser usada para sua avaliação direta, mas possui baixa sensibilidade. Geralmente, o número de cadeias ligadas ao PEG é calculado indiretamente pelo decréscimo do número de grupos amina, que não reagiram em relação à quantidade total presente antes da reação, pelo uso dos métodos colorimétrico ou fluorimétrico. Entretanto, esses métodos podem conferir resultados discutíveis devido à variabilidade intrínseca da determinação colorimétrica ou fluorimétrica e da necessidade de uma avaliação separada da concentração da proteína (VERONESE, 2001).

A literatura descreve a titulação utilizando agentes químicos, como o ácido trinitrobenzeno sulfúrico (TNBS) (HABEEB, 1966), porém, tal método colorimétrico detecta apenas as lisinas não ligadas (livres) e não o número real de PEG conjugado à proteína. A reação da proteína PEGlada com o TNBS é um meio de avaliar a ocupação de grupos amina pelo PEG. Contudo, o resultado pode não ser eficaz, pois a ausência de aminas livres não comprova a presença de cadeia PEG (YU et al., 2006).

Algumas técnicas estão sendo utilizadas para caracterizar a conjugação PEG-proteína, tais como eletroforese capilar (VERONESE, 2001; YU et al., 2006; ZHENG et al., 2007; NA et al., 2008), MALDI (espectrofotometria de massa) (VERONESE, 2001; YU et al., 2006) e MALDI-TOFI (ZHENG et al., 2007; NA et al., 2008).

A maioria dessas técnicas é extremamente complexa e exige um tempo demasiadamente longo para obtenção dos resultados, além de requererem equipamentos de alto custo, bem como profissionais altamente capacitados. Assim, há a necessidade de um método simples, rápido, reprodutível, sensível e de baixo custo.

Outras técnicas utilizadas são a cromatografia de alta performance (HPLC), dentre as quais pode ser citada a interação hidrofóbica, troca iônica e gel filtração; e a eletroforese em 
gel de poliacrilamida (SDS-PAGE), que são métodos usuais em razão da disponibilidade, reprodutibilidade e facilidade de uso (ZHENG et al., 2007).

No tocante ao SDS, embora seja um método eficaz para analisar a proteína, pode ele apresentar problemas quanto à imagem da separação do produto PEGlado, já que a presença do PEG interfere na análise. Isso porque o PEG e o SDS podem formar um complexo na análise SDS-PAGE que pode ser evidenciada quando a concentração do SDS aumenta. Estudos têm demonstrado que em alguns SDS-PAGE de PEG-proteína as bandas ficaram dispersas, não nítidas e algumas até manchadas, provavelmente em razão da interação entre as cadeias do PEG (livres ou ligadas à proteína) e as miscelas do SDS, entre as cadeias do PEG e a proteína e entre a proteína PEGlada e as miscelas do SDS (ZHENG et al., 2007).

\subsubsection{Aplicações Médicas das Proteínas Modificadas pelo PEG}

As proteínas conjugadas ao PEG têm sido extensivamente estudadas em relação a terapias de doenças, como o câncer, inflamações e outras (BAILON e BERTHOLD, 1998).

No caso das enzimas serem administradas em humanos com finalidade medicamentosa diretamente na corrente sanguínea, existe a possibilidade de serem reconhecidas como uma substância estranha levando o sistema imune do paciente a produzir anticorpos específicos para a proteína administrada. A administração contínua da mesma substância pode causar reações imunes indesejadas, do tipo anafilático, que pode levar a um resultado fatal. Ademais, essas reações imunes podem reduzir o tempo de eliminação da droga fazendo com que a mesma perca com freqüência sua função e ação terapêutica (INADA et al., 1995; KODERA et al., 1998).

Os problemas imunológicos decorrentes do uso de drogas enzimáticas ou imunoglobulinas podem ser reduzidos pelo uso do PEG conjugado à proteína, o qual trará os seguintes benefícios: preservação da atividade enzimática, redução da imunoreatividade e da imunogenicidade, prolongamento da permanência da droga medicamentosa no organismo e indução de tolerância imunológica (KODERA et al., 1998, BAILON e BERTHOLD, 1998).

Desta forma, diversas proteínas PEGladas estão sendo utilizadas em terapias, como por exemplo, a asparaginase no tratamento da leucemia; a interleucina 2, que é um potencial terapêutico no tratamento do câncer e doenças infecto-contagiosas, como hepatites e AIDS; e antibióticos que são utilizados como drogas anticancerígenas, mas que possuem alta reação adversa ou baixa solubilidade, tal como a doxorrubicina. Na deficiência de enzimas por herança genética estão em uso a adenosina deaminase (ADA), a bilirrubina oxidase e a purina 
nucleosídeo fosforilase. Ainda, foram modificadas pelo PEG a glucoronisidase, $\beta$-glucosidase, $\alpha$-galactosidase, gulonolactona oxidase, dextranase, insulina e uricase, todas com o propósito de alterar o processo metabólico in vitro (KODERA et al., 1998).

Substâncias de natureza protéica, como superóxido dismutase (SOD) e catalase, estão em uso em terapia de processos inflamatórios. Já a estreptoquinase, hirudina e uroquinase estão sendo destinadas a terapias antitrombóticas (KODERA et al., 1998).

A hemoglobina e a imunoglobulina G ( $\mathrm{IgG}$ ) PEGladas estão em estudo em face dos grandes problemas gerados com infecções virais adquiridas através de transfusão sanguínea. Uma utilização mais eficiente do sangue coletado, especialmente da hemoglobulina isolada das células vermelhas, deve ser avaliada (KODERA et al., 1998).

O uso intravenoso da IgG humana tem provocado uma série de efeitos colaterais causados pela agregação da IgG, que pode ocorrer durante a produção e/ou processo de estocagem. Suzuki e colaboradores (1984 e 1989) prepararam uma IgG modificada com PEG com diferentes massas moleculares e, assim, esclareceram uma série de propriedades físicoquímicas e biológicas no que diz respeito à estrutura molecular.

Além dos benefícios já citados em relação às proteínas PEGladas, pode-se ressaltar as seguintes vantagens: alteração da biodistribuição e das propriedades biológicas, aumento da penetração em membranas, manutenção da resposta clínica com dosagens mínimas acarretando na melhora da qualidade de vida e redução do custo do tratamento (BAILON e BERTHOLD, 1998).

Muitos estudos e anos de desenvolvimento de PEGlação conferiram resultados teóricos e comerciais importantes, mas outras aplicações ainda podem ser exploradas. Os produtos já aprovados pelo FDA são uma clara demonstração da utilidade da PEGlação no aprimoramento de drogas terapêuticas. As vantagens mais relevantes consistem no prolongado tempo de permanência de tais drogas no organismo, o que permite administrações menos freqüentes; o aumento na estabilidade frente às proteases e nucleases; e a redução da imunogenicidade (VERONESE e PASUT, 2005).

\subsubsection{Imunoreatividade das Proteínas Modificadas pelo PEG}

A ação do mPEG na diminuição da antigenicidade e, conseqüentemente, da imunogenicidade, foi demonstrada com a PEGlação da estreptoquinase em pelo menos oito grupamentos aminas. Nessa condição, houve a perda do reconhecimento por anticorpos antiestreptoquinase, mas a enzima foi hábil para manter 33\% da sua atividade biológica quando 
comparada com idêntica concentração da enzima não conjugada. Entretanto, as relações entre os subtipos de célula $\mathrm{T} \mathrm{CD}^{+}$e a verdadeira função das células $\mathrm{T} \mathrm{CD} 8^{+}$ainda não eram conhecidas, pois as mesmas eram consideradas como células $\mathrm{T}$ supressoras e, assim, alguns estudos foram realizados demonstrando a capacidade da proteína PEGlada em conduzir à tolerância através de células $\mathrm{CD}^{+}$(KOIDE et al., 1982; CHEN et al., 1994).

De acordo com os autores Caliceti e Veronese (2003), a imunogenicidade e a antigenicidade da proteína diminuem frente ao aumento do número de cadeias do polímero conjugado e/ou da massa molecular do PEG. Entretanto, é plausível que tanto a redução da imunogenicidade como das ligações dos anticorpos dependem mais do número e forma das moléculas ligadas ao PEG do que do tamanho. Os mesmos autores verificaram que a asparaginase conjugada ao PEG de $10 \mathrm{kDa}$ apresentou uma redução de cerca de dez vezes de sua característica antigênica quando comparada com a asparaginase conjugada ao PEG de $5 \mathrm{kDa}$. Ademais, a estrutura ramificada do PEG de $10 \mathrm{kDa}$ foi mais eficiente quanto à redução da imunogenicidade e da antigenicidade da uricase do que a forma linear do polímero com $5 \mathrm{kDa}$. Esses resultados são atribuídos à alta massa molecular e à estrutura em forma de guarda chuva (umbrella like) do polímero ramificado, que eficientemente previne a abordagem dos anticorpos antiproteínas e células imunologicamente competentes [Figura 15].

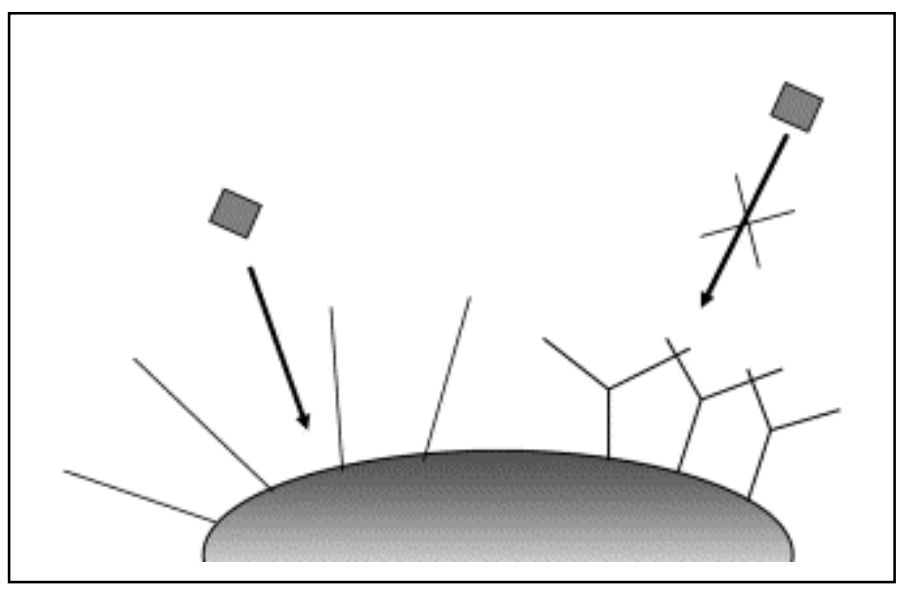

Figura 15 - Representação estrutural da proteína conjugada ao PEG linear ou ramificado. A estrutura em forma de guarda chuva (umbrella like) do PEG ramificado confere maior proteção do que o PEG linear em face da aproximação de enzimas proteolíticas, anticorpos e células fagocísticas.

Figura original: CALICETI e VERONESE, 2003. 
Ainda que a maioria dos trabalhos apresente dados de redução da reação entre anticorpos e proteínas quando conjugadas ao PEG, outros autores demonstraram um possível efeito adjuvante.

So e colaboradores (1999), demonstraram que a concentração do mPEG ativado por cloreto cianúrico, utilizado em muitos estudos para avaliação da imunotolerância de proteínas conjugadas pelo $\mathrm{mPEG}$, pode ter efeito adjuvante quando conjugado à ovoalbumina ou gama globulina bovina. Os autores verificaram que o conjugado que exibiu maior tolerância possuía entre 1,5 a 2 vezes mais massa molecular de mPEG do que a proteína.

Em 2005, estudo realizado no Instituto Butantan analisou o veneno de Bothrops jararaca conjugada ao mPEG de $2.000 \mathrm{Da}$ e 5.000 Da. As observações mais importantes referem-se à diminuição da toxicidade do veneno em pelo menos $50 \%$; a redução de efeitos adversos, em função do mPEG apresentar menor reatividade do que outros adjuvantes; o reconhecimento de todas as proteínas do veneno, inclusive peptídeos de baixa massa molecular; e a neutralização dos efeitos fisiopatológicos do veneno de Bothrops jararaca pelo soro dos animais hiperimunizados (camundongos e coelhos) (STEPHANO, 2005). 


\section{OBJETIVO}

O objetivo geral deste trabalho foi obter preparações de toxina tetânica purificada tratada pelo monometoxi-polietilenoglicol (mPEG) a fim de estudá-las como adjuvante de antígenos destinados à obtenção de soro antitetânico hiperimune. Já os objetivos específicos foram: a) estudar os efeitos biológicos do mPEG em diferentes concentrações e tamanhos, verificando a influência dessas preparações quanto à inibição da atividade neurotóxica da toxina tetânica; $b$ ) analisar os efeitos na resposta imune em cavalos e estabelecer o protocolo empregado no esquema de hiperimunização; e, $c$ ) avaliar a interferência causada pela via de inoculação no efeito adjuvante em cobaias. 


\section{MATERIAIS E MÉTODOS}

\subsection{Materiais}

\subsubsection{Microrganismo}

O microrganismo utilizado para produção da toxina tetânica foi o Clostridium tetani cepa Harvard-Caracas liofilizada, proveniente do Instituto Nacional de Salud Publica de Chile (ISP) e recebida pela Seção de Vacinas Anaeróbicas do Serviço de Bacteriologia da Divisão de Desenvolvimento Tecnológico e Produção do Instituto Butantan.

\subsubsection{Obtenção da Toxina Tetânica}

A cepa liofilizada de C. tetani foi ressuspensa em meio de tioglicolato fluido e incubada em condição de anaerobiose à temperatura de $36{ }^{\circ} \mathrm{C} \pm 1{ }^{\circ} \mathrm{C}$ durante 36 horas. Após este período realizou-se, em meio de cultura idêntico, um segundo repique incubado a $36{ }^{\circ} \mathrm{C} \pm 1{ }^{\circ} \mathrm{C}$ por 24 horas. Ao término da incubação os cultivos foram transferidos para frascos contendo $3.000 \mathrm{~mL}$ e $7.000 \mathrm{~mL}$ de meio de tioglicolato fluido (inóculo do fermentador de $360 \mathrm{~L}$ e do fermentador de $420 \mathrm{~L}$, respectivamente). Esses cultivos, denominados Inóculo de Produção, foram incubados à temperatura de $36{ }^{\circ} \mathrm{C} \pm 1{ }^{\circ} \mathrm{C}$ por um período de 8 horas. $\mathrm{Na}$ seqüência, procedeu-se à inoculação dos fermentadores de $360 \mathrm{~L}$ (Bilthoven) e $420 \mathrm{~L}$ (Chemap) contendo meio IB para produção de toxina tetânica (LATHAM et al., 1962; FRATELLI et al., 1993). Após o tempo de crescimento ( $88 \mathrm{~h} \pm 1 \mathrm{~h}$ a $35^{\circ} \mathrm{C} \pm 1{ }^{\circ} \mathrm{C}$ ) as células bacterianas foram separadas da toxina tetânica através de filtração tangencial em sistema Prostak $^{\mathrm{TM}}$ (Millipore, Molsheim, França) e a toxina foi concentrada por ultrafiltração molecular em sistema Helicon $^{\mathrm{TM}}$ (Millipore, São Paulo, Brasil) de 30 kDa. Posteriormente, a Toxina Tetânica Concentrada foi purificada [item 4.1.3] ou destoxificada [item 4.1.4].

\subsubsection{Purificação da Toxina Tetânica Concentrada}

O procedimento de purificação da Toxina Tetânica Concentrada consistiu em: concentração no sistema de filtração tangencial LabScale ${ }^{\mathrm{TM}}$ (Millipore, Billerica, U.S.A.) com membranas de $100 \mathrm{kDa}$ até a redução de 6 a 10 vezes em relação ao volume inicial e posterior 
precipitação por 33\% p/v de sulfato de amônio p.a., pH de 5,0 a 6,0 à temperatura ambiente e com agitação limite a $100 \mathrm{rpm}$. O produto foi mantido sob agitação até a dissolução total do sulfato e, após, distribuído nos frascos para centrifugação. O material foi centrifugado a $5.000 \mathrm{rpm}$ durante 20 minutos a $0{ }^{\circ} \mathrm{C}$, em centrífuga Beckman (J2-21). O precipitado foi ressuspenso em água purificada em volume suficiente para a sua dissolução. Após dissolução do precipitado, para eliminação de impurezas insolúveis, o material foi novamente centrifugado no mesmo equipamento, a $8.000 \mathrm{rpm}$ durante 90 minutos a $0{ }^{\circ} \mathrm{C}$. O sobrenadante foi dialisado no sistema de filtração tangencial com membranas de $100 \mathrm{kDa}$ para eliminação do sulfato de amônio (controlada com solução de cloreto de bário). No mesmo equipamento, a toxina tetânica foi concentrada de 6 a 10 vezes. O produto purificado foi filtrado em membrana de 0,22 $\mu \mathrm{m}$, tendo sido extraídas amostras para as provas físico-químicas, biológicas, microbiológicas e imunoquímicas. A Toxina Tetânica Purificada foi estocada à temperatura de $2^{\circ} \mathrm{C}$ a $8{ }^{\circ} \mathrm{C}$ (PRADO et al., 1992, 1993).

\subsubsection{Destoxificação da Toxina Tetânica Concentrada}

A Toxina Tetânica Concentrada [item 4.1.2] foi destoxificada utilizando-se os agentes químicos: formaldeído (1\%), glicina ( $1 \mathrm{~g}$ para cada $1,2 \mathrm{~mL}$ de formaldeído) e bicarbonato de sódio $(0,5 \mathrm{~g} \%)$. Em seguida, o produto foi filtrado por membrana de $0,22 \mu \mathrm{m}$ e incubado à temperatura de $36{ }^{\circ} \mathrm{C} \pm 1{ }^{\circ} \mathrm{C}$ durante 30 dias. Ao término desse período foram coletadas amostras para realização de testes físico-químicos, biológicos e microbiológicos. Após a conclusão do teste de Toxicidade Específica [item 4.2.9] o produto foi denominado de Anatoxina Tetânica a Granel.

\subsubsection{Purificação da Anatoxina Tetânica a Granel}

A Anatoxina Tetânica a Granel foi purificada através de diafiltração e concentração em sistema Pellicon $^{\mathrm{TM}}$ (Millipore, Billerica, U.S.A.) com membrana de $50 \mathrm{kDa}$ e posterior etapa de cromatografia em resina Sephacryl S-200 HR (Amercham Biosciences, Uppsala, Suécia) (VANCETTO et al., 1997; PRADO et al., 1999). O produto purificado recebeu a denominação Anatoxina Tetânica Produto Acabado a Granel. 


\subsubsection{Preparação do Toxóide Tetânico (TT)}

A Anatoxina Tetânica Purificada foi diluída com PBS pH 6,4 para a concentração de 20 Lf/mL [item 4.2.2] e adsorvida com gel de hidróxido de alumínio [item 4.1.7] na concentração entre 0,5 a $0,8 \mathrm{mg} \mathrm{Al} / \mathrm{mL}$. O timerosal foi adicionado como conservante na concentração de $0,01 \mathrm{~g} \%$.

\subsubsection{Gel de Hidróxido de Alumínio - $\mathrm{Al}(\mathrm{OH})_{3}$}

Gel da marca Alhydrogel 2\% (Brenntag Biosector A/S, Elsenbakken, Dinamarca), aprovado e liberado pelo Serviço de Controle de Qualidade Interno da Divisão de Desenvolvimento Tecnológico e Produção do Instituto Butantan.

\subsection{8 mPEG-SPA 5.000 e mPEG-SPA 20.000}

Monometoxi-polietilenoglicol succinimidil ácido propiônico (mPEG-SPA), de massa molecular 5.000 Da (catalog number 2M4M0H01) e 20.000 Da (catalog number 2M4M0P01) (Nektar TM Therapeutics, Huntsville, Alabama, E.U.A.), mPEG-SPA 5.000 e mPEG-SPA 20.000, respectivamente, foram utilizados nos ensaios de peglação.

\subsubsection{Preparação dos Antígenos}

\subsubsection{Toxina Tetânica Fluida e Toxina Tetânica Fluida e Adsorvida pelo Gel $\mathrm{Al}(\mathrm{OH})_{3}$}

A Toxina Tetânica Purificada [item 4.1.3] foi diluída em PBS pH 7,4 para a concentração de $1 \mathrm{mg} / \mathrm{mL}$. Avaliou-se o valor da concentração por meio do método de Bradford (1976) [item 4.2.5]. Amostras da Toxina Tetânica Fluida foram adsorvidas (1 mg de Al por $\mathrm{mL}$ de toxina) em gel de $\mathrm{Al}(\mathrm{OH})_{3}$ [item 4.1.7].

\subsubsection{Conjugação da Toxina Tetânica com mPEG-SPA}

Objetivando o preparo das soluções de Toxina Tetânica PEGladas, o mPEG-SPA5.000 e o mPEG-SPA 20.000 foram retirados do freezer $\left(-20^{\circ} \mathrm{C}\right)$ e mantidos por uma hora em temperatura ambiente. Após, a quantidade de mPEG-SPA indicada para cada experimento 
[Tabela 4] foi pesada em balança analítica e ao término os frascos contendo os mPEG-SPA foram fechados em atmosfera de gás inerte (Argônio U, White Martins, São Paulo, Brasil) antes da estocagem em freezer $\left(-20^{\circ} \mathrm{C}\right)$.

A proporção entre a quantidade de mPEG-SPA e toxina tetânica foi definida em número de moles. Assim, como a massa molecular da toxina tetânica é igual a $150 \mathrm{kDa}$ (RAPPUOLI, 1997; TURTON et al., 2002; LALLI et al., 2003), ao utilizar-se o mPEG-SPA 5.000 a relação é de 1:3,5 e a relação para o mPEG-SPA 20.000 é 1:14 para obter $100 \%$ de conjugação. Como cada molécula da toxina tetânica tem 99 lisinas [Figuras 3 a 5], são necesários 3,3 vezes mais massa de mPEG-SPA 5.000 para se ligar à 99 lisinas da toxina e 13,2 vezes mais massa de mPEG-SPA 20.000 para se ligar a 99 lisinas da toxina tetânica.

A quantidade de mPEG-SPA indicada para cada experimento foi acrescentada ao PBS pH 7,4 e aferiu-se o pH. Na seqüência, acrescentou-se a Toxina Tetânica Purificada [item 4.1.3] diluída em PBS pH 7,4 para a concentração de $1 \mathrm{mg} / \mathrm{mL}$. Comprovou-se essa concentração através do método de Bradford (1976) [item 4.2.5]. Deixou-se a solução reagir em câmara-fria $\left(2^{\circ} \mathrm{C}\right.$ a $\left.8{ }^{\circ} \mathrm{C}\right)$ durante, no mínimo, 24 horas antes da utilização nos ensaios.

Tabela 4 - Concentração (mg) de mPEG-SPA frente a 1 mg de Toxina Tetânica Purificada

\begin{tabular}{|c|c|c|}
\hline mPEG-SPA (kDa) & $\begin{array}{c}\text { PEGLAÇÃO } \\
\text { TEÓRICA }\end{array}$ & $\begin{array}{c}\text { CONCENTRAÇÃO (mg) } \\
\text { TOXINA TETÂNICA : mPEG-SPA }\end{array}$ \\
\hline \multirow{6}{*}{ Toxina Tetânica mPEG-SPA 5.000} & $100 \%$ & $1: 3,5$ \\
\hline & $60 \%$ & $1: 2$ \\
\hline & $50 \%$ & $1: 1,75$ \\
\hline & $30 \%$ & $1: 1$ \\
\hline & $15 \%$ & $1: 0,5$ \\
\hline & $6 \%$ & $1: 0,2$ \\
\hline \multirow{6}{*}{ Toxina Tetânica mPEG-SPA 5.000(2X) } & $200 \%$ & $1: 7$ \\
\hline & $120 \%$ & $1: 4$ \\
\hline & $100 \%$ & $1: 3,5$ \\
\hline & $60 \%$ & $1: 2$ \\
\hline & $30 \%$ & $1: 1$ \\
\hline & $12 \%$ & $1: 0,4$ \\
\hline \multirow{5}{*}{ Toxina Tetânica mPEG-SPA 20.000} & $100 \%$ & $1: 14$ \\
\hline & $60 \%$ & $1: 8$ \\
\hline & $30 \%$ & $1: 4$ \\
\hline & $15 \%$ & $1: 2$ \\
\hline & $6 \%$ & $1: 0,8$ \\
\hline \multirow{5}{*}{ Toxina Tetânica mPEG-SPA 20.000(2X) } & $200 \%$ & $1: 28$ \\
\hline & $120 \%$ & $1: 16$ \\
\hline & $60 \%$ & $1: 8$ \\
\hline & $30 \%$ & $1: 4$ \\
\hline & $12 \%$ & $1: 1,6$ \\
\hline
\end{tabular}




\subsubsection{Toxina Tetânica Conjugada com mPEG-SPA e Adsorvida pelo Gel de $\mathrm{Al}(\mathrm{OH})_{3}$}

Amostras de Toxina Tetânica Purificada conjugadas com mPEG-SPA, denominadas de Toxina Tetânica mPEG-SPA 5.000 e Toxina Tetânica mPEG-SPA 5.000(2X) com PEGlação teórica de 50\% e 100\% respectivamente [item 4.1.9.2], foram adsorvidas (1 mg de $\mathrm{Al}$ por $\mathrm{mL}$ de toxina) em gel de $\mathrm{Al}(\mathrm{OH})_{3}$ [item 4.1.7]. Deixou-se a solução reagir em câmarafria $\left(2{ }^{\circ} \mathrm{C} \mathrm{a} 8{ }^{\circ} \mathrm{C}\right)$ por, no mínimo, 24 horas antes da utilização nos ensaios.

\subsection{Métodos Analíticos}

\subsubsection{Monitoramento do Grau de PEGlação da Toxina Tetânica}

O grau de PEGlação da toxina tetânica foi determinado por colorimetria, utilizando-se a técnica do ácido trinitrobenzeno sulfúrico (TNBS) (HABEEB, 1966). A proteína correspondeu à Toxina Tetânica Purificada, cuja concentração $(\mathrm{mg} / \mathrm{mL})$ foi determinada conforme o item 4.2.5. A reação foi conduzida da seguinte maneira: em uma série de 9 tubos (polipropileno fundo cônico), para cada $1 \mathrm{~mL}$ de solução de proteína $(0,1 ; 0,2 ; 0,3 ; 0,4 ; 0,5$; 0,$6 ; 0,7 ; 0,8$ e $0,9 \mathrm{mg} / \mathrm{mL}$ ), adicionou-se $1 \mathrm{~mL}$ de solução de bicarbonato de sódio p.a. a 4\%, pH 8,5, e $1 \mathrm{~mL}$ de TNBS (Sigma, St. Louis, Missouri, E.U.A.) a 0,1\% em água destilada. A solução foi incubada em banho-maria à $40{ }^{\circ} \mathrm{C}$ durante 2 horas. Posteriormente adicionou-se $1 \mathrm{~mL}$ de dodecil sulfato de sódio (SDS) a 10\% em água destilada com o objetivo de solubilizar a proteína e prevenir a precipitação quando da adição posterior de $0,5 \mathrm{~mL}$ de ácido clorídrico a 1 N. Através de espectrofotômetro (Spectronic, modelo Genesys 5) a absorbância da solução foi lida a $435 \mathrm{~nm}$ frente a um branco tratado, conforme citado acima $(1.000 \mu \mathrm{L}$ de água destilada), mas sem a adição da proteína. Considerou-se o valor da absorbância da Toxina Tetânica Purificada igual a 100\% de aminas livres e os valores de absorbância referentes às amostras das toxinas PEGladas [item 4.1.9.2] permitiram a quantificação de aminas livres capazes de reagir com o TNBS. Assim, o grau de peglação após a reação de conjugação foi calculado a partir da diferença entre a porcentagem das aminas livres da Toxina Tetânica Purificada não conjugada e da porcentagem de aminas livres das amostras conjugadas. 


\subsubsection{Determinação do Limite de Floculação}

A determinação do limite floculante foi realizada segundo a técnica de Gaston Ramon (LYNG e BENTZON, 1987), onde os títulos das toxinas e anatoxinas foram determinados frente a uma antitoxina tetânica de referência com concentração de $100 \mathrm{Lf} / \mathrm{mL}$ (padronizada pelo Serviço de Controle de Qualidade Interno do Instituto Butantan). A técnica consistiu, basicamente, na adição em tubos de volumes variáveis de antitoxina tetânica contendo $100 \mathrm{Lf} / \mathrm{mL}$ e adição de $1 \mathrm{~mL}$ de toxina ou anatoxina tetânica. Os tubos foram agitados e incubados em banho-maria à $45^{\circ} \mathrm{C}$. O monitoramento foi realizado através da observação da reação de floculação, perceptível a olho nu. O resultado foi considerado pelo primeiro tubo contendo a mistura em que ocorreu a floculação. O valor em $\mathrm{Lf} / \mathrm{mL}$ é dado pelo volume de antitoxina tetânica padronizada presente no tubo multiplicado por sua concentração em equivalente $(\mathrm{Lf} / \mathrm{mL})$ da toxina ou anatoxina tetânica. O tempo $(\mathrm{Kf})$ correspondente para ocorrer a floculação também foi registrado.

\subsubsection{Determinação do Nitrogênio Protéico}

As amostras de toxina e anatoxina tetânica foram submetidas ao Método de MicroKjeldhal para avaliação quantitativa de nitrogênio protéico e não protéico em $\mathrm{mg} / \mathrm{mL}$ (BRASIL, 1996; WORLD HEALTH ORGANIZATION, 1977).

\subsubsection{Determinação da Pureza Antigênica}

A pureza antigênica ( $\mathrm{Lf} / \mathrm{mgNP}$ ) foi obtida a partir da relação entre o valor em $\mathrm{Lf} / \mathrm{mL}$ e a concentração em mg de nitrogênio protéico/mL $(\mathrm{mgNP} / \mathrm{mL})$. A Anatoxina Tetânica Produto Acabado a Granel deve apresentar no mínimo 1.000 Lf/mg de nitrogênio protéico (WORLD HEALTH ORGANIZATION, 1977; BRASIL, 1996).

\subsubsection{Determinação da Concentração de Proteínas}

Realizou-se a determinação da concentração de proteínas pelo método de Bradford (1976) através do Bio-Rad Protein Assay Kit (Bio-Rad Laboratories, Richmond, California, U.S.A.). 


\subsubsection{Determinação de Alumínio}

A determinação do alumínio tem por objetivo a avaliação quantitativa de alumínio $\left(\mathrm{Al}^{3+}\right)$ em $\mathrm{mg} / \mathrm{mL}$. A determinação foi realizada através da complexação do alumínio com ácido etilenodiamino tetra-acético (EDTA) sendo o excesso titulado com sulfato de cobre (WORLD HEALTH ORGANIZATION, 1982; BRASIL, 1998; EUROPEAN PHARMACOPOEIA, 2005), tendo sido realizado nas amostras de gel de $\mathrm{Al}(\mathrm{OH})_{3}$ e de produtos adsorvidos com o mesmo.

\subsubsection{Determinação do Teor de Sulfato de Amônio}

A determinação do teor de sulfato de amônio tem por finalidade a avaliação quantitativa de sulfato de amônio em ppm (BRASIL, 1996). O teor de sulfato de amônio foi determinado por método colorimétrico onde o valor foi exibido por comparação entre a amostra e diluições da solução padrão (WORLD HEALTH ORGANIZATION, 1982).

\subsubsection{Determinação de Timerosal}

A determinação de timerosal tem por objetivo a avaliação quantitativa de timerosal em ppm. A concentração do timerosal foi analisada através da absorbância do produto resultante da reação do mercúrio nele contido com a difenilcarbazona (ditizona) previamente purificada (BRASIL, 1996).

\subsubsection{Prova de Toxicidade Específica}

O volume de 5,0 mL de Anatoxina Tetânica Produto Acabado a Granel (concentração de $100 \mathrm{Lf} / \mathrm{mL}$ ) foi inoculado em 5 cobaias de 250 a 350 g por via subcutânea. Os animais foram observados durante 4 semanas. A prova somente é considerada satisfatória se no mínimo $80 \%$ dos animais inoculados sobreviver durante o período de observação sem apresentar sinais de intoxicação tetânica (WORLD HEALTH ORGANIZATION, 1977; BRASIL, 1996). Os animais empregados nesse teste, bem como nos testes descritos nos sub itens 4.2.10, 4.2.11 e 4.3.1, foram mantidos no Infectório da Seção de Controle Biológico do Serviço de Controle de Qualidade Interno da Divisão de Desenvolvimento Tecnológico e Produção do Instituto Butantan. 


\subsubsection{Determinação da Atividade Imunogênica (determinação do título antitóxico em soros de animais imunizados)}

Amostra de Toxóide Tetânico [item 4.1.6] foi inoculada em volume de 0,75 mL por via subcutânea (metade da dose total humana) em grupos de 6 cobaias (450 a 550 g) que, após seis semanas da inoculação, foram sangradas através de punção cardíaca para titulação da antitoxina em camundongos (albinos suíços de 17 a 22 g) (WORLD HEALTH ORGANIZATION, 1977; BRASIL, 1996, 1998). Ressalte-se que os animais foram sangrados, de acordo com os princípios éticos da experimentação animal.

\subsubsection{Determinação da Dose Limite Morte $\left(\mathrm{L}^{+}\right)$}

A dose $\mathrm{L}+/ 10$ é o menor volume de Toxina Tetânica que, quando combinado com 0,1 UI de Antitoxina Tetânica de Referência, provoca a morte de 100\% dos camundongos em 96 horas. Para tanto, a Antitoxina Tetânica de Referência foi diluída para a concentração de $1 \mathrm{UI} / \mathrm{mL}$ em PBS pH 7,2; sendo colocado $1 \mathrm{~mL}$ da mesma em uma série de tubos. $\mathrm{Na}$ seqüência, foram adicionados volumes crescentes de Toxina Tetânica em cada um dos tubos que, depois de homogeneizados, foram incubados à temperatura de $37^{\circ} \mathrm{C}$ durante uma hora para então proceder à inoculação $(0,2 \mathrm{~mL} /$ camundongo) em 10 camundongos albinos suíços pesando entre 17 e $22 \mathrm{~g}$. Os animais foram observados diariamente durante 96 horas, registrando-se tanto a ausência como a presença de sintomas característicos de tétano, bem como a morte dos animais (WORLD HEALTH ORGANIZATION, 1977; BRASIL, 1996, 1998).

\subsubsection{Titulação da Antitoxina Tetânica}

Em uma série de tubos foram distribuídos volumes variáveis do soro coletado das cobaias imunizadas. Adicionou-se a cada tubo volume constante de Toxina Tetânica (padronizada em $\mathrm{L}+/ 10$, item 4.2.10.1). O volume de todos os tubos foi igualado com PBS pH 7,2 peptonada a 1\%. Após homogeneização e incubação à $37{ }^{\circ} \mathrm{C}$ durante 45 minutos, cada amostra foi injetada por via subcutânea em 10 camundongos albinos suíços de 17 a 22 g $(0,2 \mathrm{~mL} /$ animal $)$. O volume inoculado continha uma $\mathrm{L}+/ 10 / 50$. Os animais foram observados diariamente por um período de 96 horas, após o qual realizou-se o cálculo da $\mathrm{DL}_{50}$ [item 4.2.11] (WORLD HEALTH ORGANIZATION, 1977; BRASIL, 1996, 1998). 


\subsubsection{Determinação da $\mathrm{DL}_{50}$ (Dose Letal $50 \%$ )}

Os testes de $\mathrm{DL}_{50}$ foram realizados em camundongos albinos suíços com peso entre 17 e 22 g inoculados subcutâneamente com $1 \mathrm{~mL}$ de diluições crescentes (PBS pH 7,2 peptonada a 1\%) das amostras de Toxina Tetânica Purificada tratadas ou não com mPEG-SPA. Cada uma das diluições foram inoculados em 10 camundongos (1,0 mL/animal). Durante o tempo de observação de 96 horas registrou-se tanto a ausência como a presença de sintomas característicos de tétano, bem como a morte dos animais. Ao final, realizou-se o cálculo da $\mathrm{DL}_{50}$, cujo valor foi determinado mediante o emprego de Probitos que transforma os dados obtidos em regressão linear. $\mathrm{A} \mathrm{DL}_{50}$ é a dose de toxina capaz de provocar a morte de $50 \%$ dos animais inoculados (BRASIL, 1996).

\subsubsection{ToBI Teste (Toxin Inhibition Test)}

Microplacas de poliestireno de 96 poços de fundo chato, identificadas como $\mathrm{N}^{\circ} 1$ [Figura 16] (Microtiter Fonda Celleta Piatto código 655101, Itália), foram bloqueadas com $300 \mu \mathrm{L} /$ poço de PBS pH 7,2 com adição de Tween 80 (Merck S.A., Alemanha) a 0,05\% (PBST80) e albumina bovina (BSA) (Sigma-Aldrich, U.S.A.) a 0,5\% e incubadas durante 90 minutos à $37^{\circ} \mathrm{C}$. Na seqüência, as placas foram lavadas com PBS-T80 no lavador de placas de Imunologia com 96 poços (WellWash 4, Labsystems, Finlândia). Após, adicionou-se, amostras dos soros em teste em duplicata e do soro padrão (concentração 4,6 UI/mL), em diluições seriadas em PBS pH 7,2 (100 $\mu \mathrm{L}$ /poço), assim como $100 \mu \mathrm{L} /$ poço de Anatoxina Tetânica $(1,8 \mu \mathrm{g} / \mathrm{mL}$ e 0,5 Lf/mL). O soro padrão (Tetanus Antitoxin, Equine, For Biossay, 3rd British Standard NIBSC Code No. 60/013, 230 International Units of tetanus antitoxin) utilizado é proveniente do National Institute for Biological Standards and Control (NIBSC). As placas foram incubadas a $37^{\circ} \mathrm{C}$ durante 60 minutos e, em seguida, a $4{ }^{\circ} \mathrm{C}$ overnight. Outro grupo distinto de microplacas de poliestireno para ELISA de 96 poços de fundo chato, identificadas como $\mathrm{N}^{\circ} 2$ (Nunc-Immuno $^{T M}$ Plate, MaxiSorp ${ }^{T M}$ Surface, Nalge Nunc International, Dinamarca) [Figura 16], foram sensibilizadas com $300 \mu \mathrm{L}$ de Soro Antitetânico (produzido no Instituto Butantan) sem albumina diluído em solução tampão bicarbonato de sódio e carbonato de sódio pH 9,6 à $0,05 \mathrm{M}$ com concentração final de $12 \mu \mathrm{g} / \mathrm{mL}$ de anticorpos antitetânico. Após a incubação overnight a $4{ }^{\circ} \mathrm{C}$ foram realizadas lavagens com PBS-T80. Na seqüência, as placas $\mathrm{N}^{\circ} 2$ foram bloqueadas com PBS-T80 e BSA a $0,5 \%, 300 \mu \mathrm{L} /$ poço e incubadas durante 90 minutos a $37{ }^{\circ} \mathrm{C}$. Após, foram lavadas com 
PBS-T80 transferindo-se $100 \mu \mathrm{L}$ da solução contida na última linha da placa $\mathrm{N}^{\circ} 1$ para a linha correspondente da placa $\mathrm{N}^{\circ} 2$ e assim com todas as linhas das placas dando continuidade à transferência no sentido de baixo para cima. Ao término da transferência as placas $\mathrm{N}^{\circ} 2$ foram incubadas durante 90 minutos a $37^{\circ} \mathrm{C}$ e lavadas com PBS-T80. Após, $100 \mu \mathrm{L}$ de anticorpo antitetânico acoplado a Peroxidase Tipo VI-A (Sigma-Aldrich, U.S.A.), diluído em PBS $\mathrm{pH} 7,2$ para concentração final de $3 \mu \mathrm{g} / \mathrm{mL}$, foi colocado em todos os poços das placas $\mathrm{N}^{\circ} 2$ (com exceção da coluna 1). Após incubar a $37{ }^{\circ} \mathrm{C}$ durante 90 minutos e lavar com PBS-T80, adicionou-se $100 \mu \mathrm{L} /$ poço de solução tampão ácido cítrico e fosfato de sódio $\mathrm{pH}$ 5,0 à $0,15 \mathrm{M}$ com adição de o-Phenylenediamine (OPD) (Sigma-Aldrich Chemie Gmbr, Alemanha) e peróxido de hidrogênio (Sigma-Aldrich Chemie Gmbr, Alemanha). Aguardou-se por um período máximo de 15 minutos até ocorrer a coloração, adicionando-se, então, $50 \mu \mathrm{L}$ de solução de ácido sulfúrico $4 \mathrm{~N}$ em todos os poços para cessar a formação da coloração. Os títulos foram obtidos por meio de determinação de densidade ótica (D.O.) através do leitor de ELISA (Multiskan EX, Labsystems, Finlândia) em comprimento de onda de $492 \mathrm{~nm}$. A quantificação do nível de anticorpo antitetânico detectado nos soros testados, em UI/mL, foi realizada através de uma curva de regressão linear obtida com diferentes concentrações do soro padrão em UI/mL versus a leitura de densidade óptica em cada concentração do padrão utilizada (HENDRIKSEN et al., 1988, NISHIKAWA et al., 1995; SONOBE et al., 2007).

\subsubsection{Imunodifusão (Técnica de Ouchterlony)}

Sobre uma lâmina de microscópio $(7,6 \mathrm{~cm}$ x 2,6 cm) foi colocado uma tira de 7,5 cm x 2,5 cm do filme de poliéster GelBond film ${ }^{\circledR} 124 \mathrm{~mm}$ x $258 \mathrm{~mm}$ (GE Healthcare Bio-Science $A B$, Uppsala, Suécia) com a superfície hidrofílica voltada para cima. Na seqüência, adicionou-se $1 \mathrm{~g}$ de agarose (Merck S.A., Alemanha) em $100 \mathrm{~mL}$ de solução fisiológica 0,85\%, aquecendo-se a mistura em forno de microondas até a dissolução total da agarose. Foram colocados 5,0 mL de agarose sobre o centro do GelBond film ${ }^{\circledR}$ e após o resfriamento a mesma foi colocada em câmara úmida em geladeira por aproximadamente 1 hora. Posteriormente, com o auxílio de um perfurador, fez-se 7 orifícios de $4 \mathrm{~mm}$ de diâmetro cada no gel: 1 central e 6 periféricos eqüidistantes entre si e em relação ao orifício central. A agarose dos orifícios foi removida com agulha. Foram feitas diluições seriadas das amostras de soro de cavalo em solução fisiológica $0,85 \%: 1: 2 ; 1: 4 ; 1: 8 ; 1: 16 ; 1: 32$. Cada amostra pura de soro de cavalo, bem como cada diluição da respectiva amostra foram aplicadas no volume de $20 \mu \mathrm{L}$ no 
orifício correspondente e no orifício 1 foi aplicado $20 \mu \mathrm{L}$ de Toxina Tetânica Purificada $(1 \mathrm{mg} / \mathrm{mL})$ [Figura 17] e então mantidas a $37^{\circ} \mathrm{C}$ overnight em câmara úmida. Ao término da incubação, a lâmina foi imersa em solução fisiológica $0,85 \%$ por, no mínimo, 24 horas. Na seqüência, a lâmina foi retirada de dentro da solução e envolvida no meio de sete pedaços de papel de filtro e colocava-se o peso de $650 \mathrm{~g}$. O papel de filtro foi retirado delicadamente e a lâmina secada em estufa de secagem ajustada para $37^{\circ} \mathrm{C}$ até secagem total do gel. Finalizando, a fita foi corada com solução de Coomassie Blue 250 R (USB, código 32826) durante 10 minutos e o excesso de corante retirado com solução descorante $(300 \mathrm{~mL}$ de metanol, $100 \mathrm{~mL}$ de ácido acético, $0,5 \mathrm{~mL}$ de formaldeído e água purificada q.s.p. $1.000 \mathrm{~mL}$ ). Na leitura foi observada a presença ou não de linhas de precipitação, reação de identidade entre os componentes analisados (BIER, 1978c).

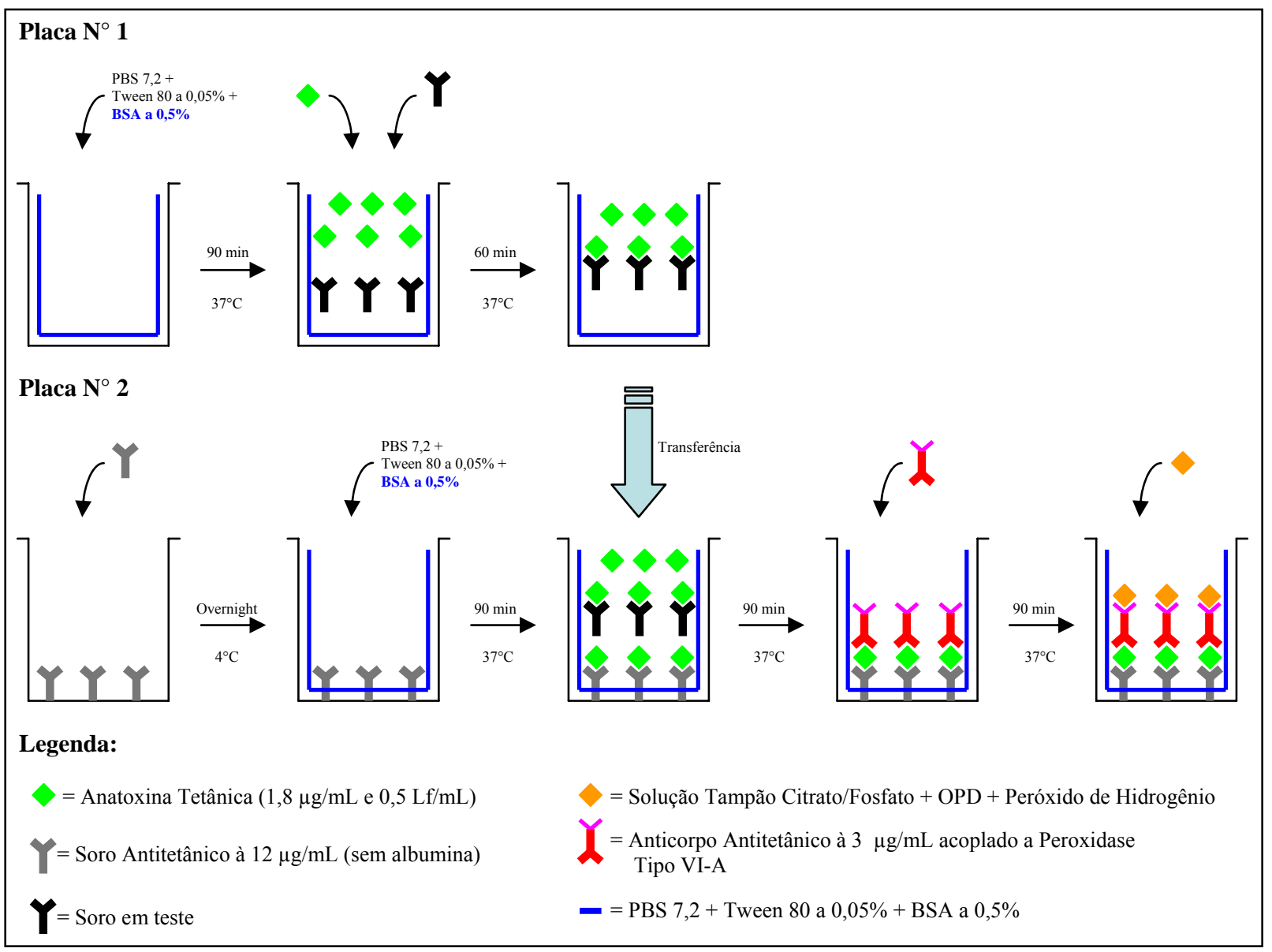

Figura 16 - ToBI Teste (Toxin Inhibition Test) - esquema ilustrativo. 


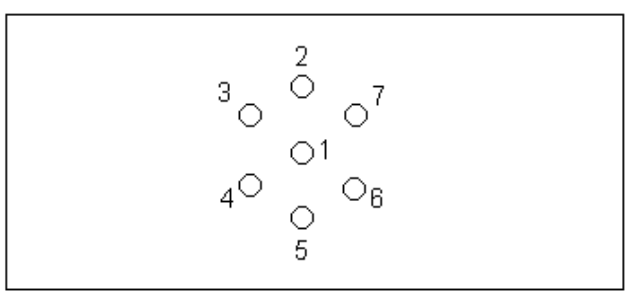

Figura 17 - Imunodifusão. Orifício 1 - Toxina Tetânica Purificada $(1 \mathrm{mg} / \mathrm{mL})$. Orifício 7 - Amostra diluída 1:2. Orifício 6 - Amostra diluída 1:4. Orifício 5 - Amostra diluída 1:8. Orifício 4 - Amostra diluída 1:16. Orifício 3 - Amostra diluída 1:32. Orifício 2 - Amostra pura.

\subsubsection{Eletroforese em Gel de Poliacrilamida (SDS-PAGE)}

Com o objetivo de determinar a massa molecular das proteínas existentes nas amostras de toxina tetânica purificada tratadas ou não com mPEG-SPA, bem como das amostras dos soros de cavalos, ao término da imunização [item 4.3.2.7] realizou-se à eletroforese em gel de poliacrilamida (LAEMMLI, 1970; NEVILLE, 1971). Para as amostras de toxina tetânica purificada tratadas ou não com mPEG-SPA o gel de acrilamida foi preparado a uma concentração de $10 \%$ para o gel de corrida e de 5\% para o gel de empilhamento. Para aplicação no gel de eletroforese as amostras de toxina tetânica receberam dois tratamentos distintos: a) foram aquecidas por 5 minutos em banho de água fervente na presença de 2-mercaptoetanol; b) não foram aquecidas e nem colocadas na presença de 2-mercaptoetanol. Assim, foram obtidos dois géis de eletroforese, um com a toxina tetânica reduzida pelo 2-mercaptoetanol e o outro sem que a toxina tetânica fosse reduzida. De cada uma das amostras de toxina tetânica purificada tratada com mPEG-SPA, aplicou-se ao gel uma concentração fixa de proteínas (diluída para $1 \mathrm{mg} / \mathrm{mL}$ em água purificada), já para as amostras de toxina tetânica purificada (não tratadas pelo mPEG-SPA) adicionou-se um determinado volume fixo $(25 \mu \mathrm{L})$. Visando à determinação da massa molecular das proteínas existentes nas amostras dos soros de cada cavalo, o gel de acrilamida foi preparado a uma concentração de 7,5\% para o gel de corrida e de 5\% para o gel de empilhamento e uma determinada concentração fixa de proteínas $(0,7 \mathrm{mg} / \mathrm{mL})$ de cada amostra foi aplicada ao gel. A corrida foi realizada nas seguintes condições: $36 \mathrm{~mA}$ por 2 horas e 30 minutos em tampão Tris-Glicina 0,25 M e SDS a 1\%. As concentrações de proteínas das amostras de cada ensaio foram determinadas conforme o item 4.2.5. Uma alíquota de padrões de massa molecular (HMWSDS Marker kit, Amersham Biosciences, Piscataway, New Jersey, U.S.A.) também foi aplicada ao gel. Os géis referentes às amostras foram corados com Coomassie Blue 250 R. 


\subsubsection{Immunoblotting}

Neste ensaio, $0,7 \mathrm{mg} / \mathrm{mL}$ de toxina tetânica purificada foi diluída em tampão Tris- $\mathrm{HCl}$ 0,15 M, pH 6,8 acrescido de 4,9\% de SDS, 6,13\% de 2-mercaptoetanol, 24,5\% de glicerol e azul de bromofenol a 0,0025\%. A amostra de toxina tetânica foi aquecida em banho de água fervente por 5 minutos. Outra amostra foi preparada do mesmo modo, porém, sem a presença de 2-mercaptoetanol e sem aquecimento em água fervente. Foram obtidos, assim, dois géis de eletroforese, sendo um com a toxina tetânica reduzida pelo 2-mercaptoetanol e o outro sem que a toxina tetânica fosse reduzida.

A amostra de toxina tetânica reduzida e a amostra de toxina tetânica não reduzida foram submetidas à eletroforese em gel de poliacrilamida (SDS-PAGE) a 7,5\%. Ambos os géis apresentavam $1 \mathrm{~mm}$ de espessura, com sistema tampão Tris-Glicina 0,25 M e SDS a 1,9 M. Após a eletroforese, as frações de proteína foram transferidas para membranas de poliviniledileno flureto (PVDF - polivinyletilene difluride), com porosidade de 0,45 mm (Amersham Biosciences, Buckinghamshire, Inglaterra) em uma cuba de transferência (Hoefer Semi-dry Transfer Unit - Amersham Biosciences) na condição de 100 mA por 2 horas em tampão Tris-Glicina 0,25 M. As membranas foram bloqueadas com leite em pó desnatado (Leite Molico, Nestlé, Brasil) a 5\% em tampão Tris-HCl 50 mM, pH 7,5, NaCl 150 mM por 2 horas. Após o bloqueio, a membrana de PVDF foi cortada em tiras de aproximadamente $1 \mathrm{~cm}$ de largura, colocando-se cada tira na presença do pool dos soros de cavalos $(0,1 \mathrm{mg} / \mathrm{mL})$.

Após a incubação, as fitas foram lavadas (em intervalos de 15 minutos) com três trocas de tampão Tris- $\mathrm{HCl} 50 \mathrm{mM}, \mathrm{pH} 7,5, \mathrm{NaCl} 150 \mathrm{mM}, 0,05 \%$ de Tween 20 com 5\% de leite desnatado. As frações protéicas foram reveladas com IgG anti-cavalo com fosfatase alcalina (anti-horse IgG - whole molecule - alkaline fosfatase, antibody produced in rabbite) (Sigma aldrich Chemie, GmbH, Alemanha) diluídas 1:30.000 em tampão PBS e deixadas em contato com as fitas de PVDF por 2 horas à temperatura ambiente. Na sequência, as fitas foram lavadas (em intervalos de 15 minutos) com três trocas de tampão Tris- $\mathrm{HCl} 50 \mathrm{mM}$, $\mathrm{pH}$ 7,5, $\mathrm{NaCl} 150 \mathrm{mM}, 0,05 \%$ de Tween 20 com 5\% de leite desnatado. Em seguida as bandas de proteínas foram visualizadas por adição de substratos: 0,66 $\mathrm{mL}$ de NBT (nitroblue tetrazolium) e 0,33 mL de BCIP (5-bromo-4-chloro-3-indolyl phosphate) (USB Corporation Cleveland, $O H$, U.S.A.), diluídos em $100 \mathrm{~mL}$ de tampão $\mathrm{NaCl}$ a $100 \mathrm{mM}, \mathrm{MgCl}_{2} 5 \mathrm{mM}$ e Tris- $\mathrm{HCl} 10 \mathrm{mM}, \mathrm{pH}$ 9,5. A reação foi interrompida por adição de 0,20 mL de EDTA (0,002 M), diluído em $50 \mathrm{~mL}$ de Tris- $\mathrm{HCl} 50 \mathrm{mM}, \mathrm{pH}$ 7,5. Após, as tiras de PVDF com os 
blots foram secas, digitalizadas e analisadas para o reconhecimento das frações protéicas da toxina tetânica reduzida e não reduzida (WESTERMEIER, 1997).

\subsection{Esquemas de Imunização}

\subsubsection{Imunização das Cobaias - Estudo da Via de Inoculação}

Quatorze grupos formados por 5 cobaias cada um pesando entre 400 a $450 \mathrm{~g}$, foram inoculados com 0,75 mL (15 Lf) de Toxóide Tetânico [item 4.1.6] por via subcutânea. Em paralelo, como controle, dois outros grupos com as mesmas características foram inoculados tanto pela via subcutânea como intramuscular com $0,75 \mathrm{~mL}$ de $\mathrm{PBS} \mathrm{pH}$ 7,2. Após um intervalo de 21 dias, as cobaias receberam os antígenos descritos na Tabela 5, que correspondiam aos valores teóricos máximo e mínimo de PEGlação da Toxina Tetânica, em

volume equivalente a $5 \mathrm{Lf}$ tanto pela vias subcutânea como pela via intramuscular. Depois de 15 dias, todas as cobaias imunizadas com antígenos ou PBS $\mathrm{pH}$ 7,2 foram sangradas, conforme os princípios éticos da experimentação animal, através de punção cardíaca para titulação da antitoxina tetânica circulante presente no soro por meio do ToBI Teste [item 4.2.12]. 
Tabela 5 - Esquema de imunização em cobaias e vias utilizadas

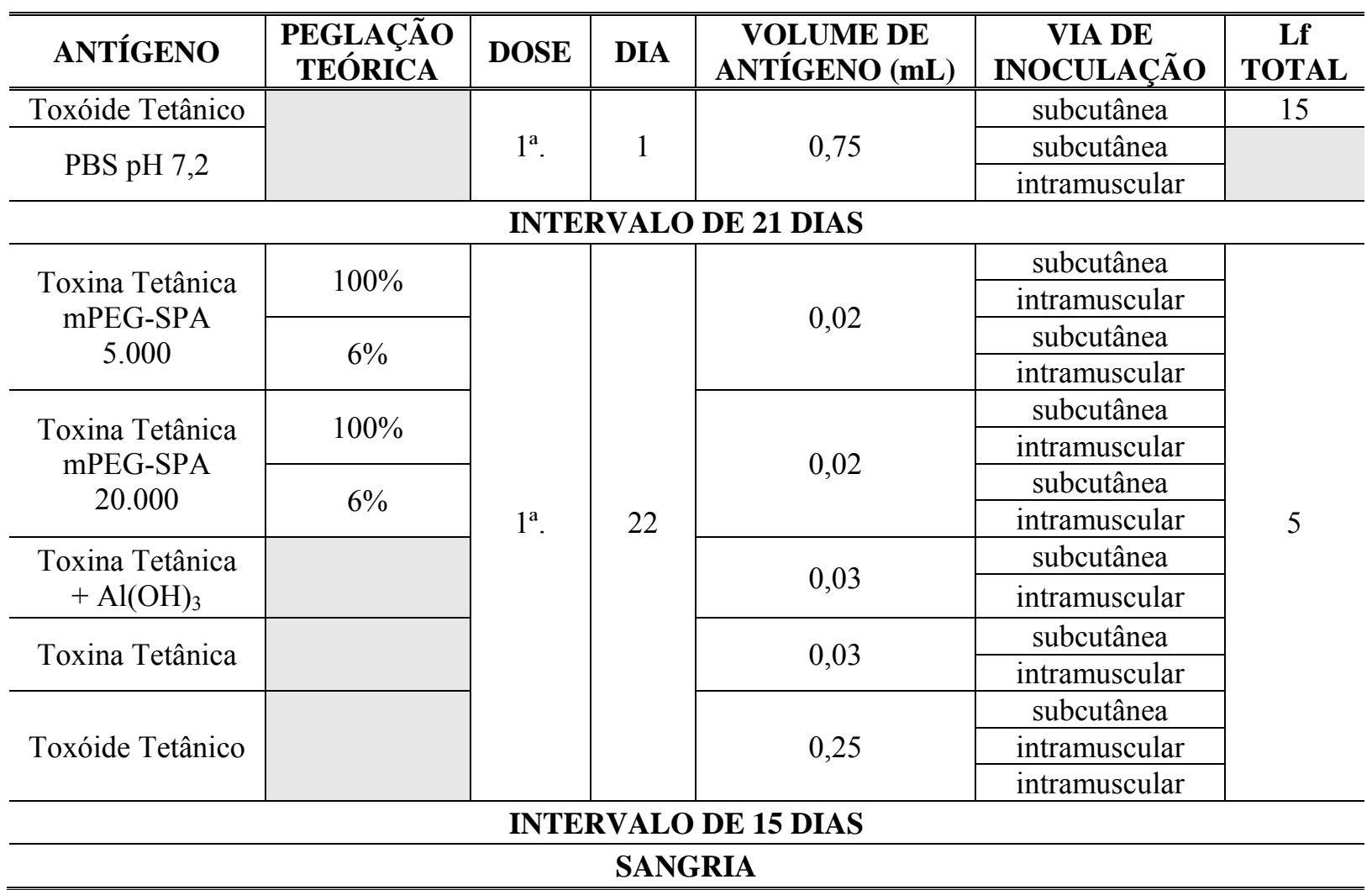

NOTA: Sangria dos animais inoculados com os antígenos experimentais, TT e com PBS pH 7,2.

\subsubsection{Imunização dos Eqüinos}

\subsubsection{Animais}

Trinta cavalos com peso e idade média de $400 \pm 20 \mathrm{Kg}$ e $6 \pm 2$ anos, respectivamente, foram adquiridos pela Fundação Butantan. Conforme procedimento em vigor no Instituto Butantan, os cavalos ficaram isolados por um período de 60 dias, sendo liberados para imunização após dois exames (com intervalo de 30 dias) de anemia infecciosa eqüina apresentarem resultados negativos. Todos os animais foram vacinados contra encefalomielite eqüina, influenza eqüina e raiva, assim como, marcados no Instituto Butantan como segue: $215,223,288,309,326,340,342,391,395,417,420,421,422,423,427,430,433,435,438$, 440, 442, 443, 451, 454, 463, 464, 465, 468, 469 e 470. Os animais foram mantidos na Fazenda São Joaquim do Serviço de Imunologia da Divisão de Desenvolvimento Tecnológico e Produção do Instituto Butantan. 


\subsubsection{Sangria Exploradora}

Objetivando acompanhar a resposta imunológica dos cavalos, antes ou após a aplicação dos antígenos, foram extraídos $40 \mathrm{~mL}$ de sangue da veia jugular de cada cavalo, e após coagulação do sangue e separação do soro a $4{ }^{\circ} \mathrm{C}$, os soros foram individualmente testados quanto à concentração de anticorpos antitetânicos [item 4.2.12].

\subsubsection{Vacinação Antitetânica}

Primeiramente, realizou-se a sangria exploradora de todos os 30 cavalos [item 4.3.2.2]. $\mathrm{Na}$ seqüência, todos foram vacinados contra o tétano recebendo por via intramuscular (IM) uma dose de 5,0 mL de Anatoxina Tetânica Produto Acabado a Granel [item 4.1.5] contendo $100 \mathrm{Lf} / \mathrm{mL}$ e adsorvida em gel de $\mathrm{Al}(\mathrm{OH})_{3}$ [item 4.1.7] (1 mg de $\mathrm{Al}$ por $\mathrm{mL}$ de anatoxina). A dose foi aplicada em um ponto no dorso do animal. No $28^{\circ}$ dia após a aplicação da vacina todos os cavalos foram submetidos à sangria exploradora [item 4.3.2.2].

\subsubsection{Imunização Seletiva}

Realizou-se a imunização seletiva (GUIDOLIN et al., 1992) a fim de selecionar em curto prazo, plantel de animais relativamente homogêneo quanto aos títulos de anticorpos tetânicos, com dados obtidos entre os 30 cavalos testados [item 4.3.2.1]. Após 85 dias da aplicação da vacina, todos os cavalos foram submetidos à sangria exploradora [item 4.3.2.2] e, na seqüência, receberam por via intramuscular uma dose de 5,0 $\mathrm{mL}$ de Anatoxina Tetânica Produto Acabado na Granel [item 4.1.5] contendo $200 \mathrm{Lf} / \mathrm{mL}$ e adsorvida ao gel de $\mathrm{Al}(\mathrm{OH})_{3}$ [item 4.1.7] ( $1 \mathrm{mg}$ de $\mathrm{Al}$ por $\mathrm{mL}$ de anatoxina). As doses foram aplicadas em um único ponto no dorso de cada animal. Após 27 dias, todos animais foram submetidos à sangria exploradora [item 4.3.2.2] sendo que os 18 cavalos que apresentaram os melhores títulos de antitoxina tetânica circulante foram selecionados para prosseguimento do estudo, enquanto os demais cavalos foram incorporado ao plantel do Instituto Butantan. Depois de 15 dias, os 18 cavalos selecionados receberam por via intramuscular uma dose de 5,0 mL de Anatoxina Tetânica Produto Acabado a Granel [item 4.1.5] contendo $200 \mathrm{Lf} / \mathrm{mL}$ e adsorvida ao gel de $\mathrm{Al}(\mathrm{OH})_{3}$ [item 4.1.7] ( $1 \mathrm{mg}$ de $\mathrm{Al}$ por $\mathrm{mL}$ de anatoxina). As doses foram aplicadas em um único ponto no dorso de cada animal. Após 32 dias, todos animais foram submetidos à sangria exploradora 
[item 4.3.2.2] e os soros foram individualmente testados quanto à concentração de antitoxina tetânica circulante $(\mathrm{UI} / \mathrm{mL})$ [item 4.2.12].

\subsubsection{Formação dos Grupos}

Os 18 cavalos selecionados foram divididos em três grupos distintos [Tabela 6], com destino à imunização com os antígenos Toxina Tetânica mPEG-SPA 5.000 e Toxina Tetânica mPEG-SPA 5.000(2X) [item 4.1.9.2], e como controle a Toxina Tetânica Fluida [item 4.1.9.1].

Tabela 6 - Grupos de cavalos e antígenos empregados nos esquemas de hiperimunização

\begin{tabular}{c|c|c}
\hline \hline GRUPO & ANTÍGENO & IDENTIFICAÇÃO DO CAVALO \\
\hline \hline \multirow{4}{*}{1} & & 223 \\
& & 340 \\
& Toxina Tetânica & 420 \\
& mPEG-SPA 5.000 & 430 \\
& & 433 \\
& & 443 \\
\hline \multirow{3}{*}{2} & & 215 \\
& & 395 \\
& Toxina Tetânica & 427 \\
& mPEG-SPA 5.000(2X) & 440 \\
& & 464 \\
& & 469 \\
\hline \multirow{3}{*}{3} & & 326 \\
& & 391 \\
& & 442 \\
& & 451 \\
& & 454 \\
\hline \hline
\end{tabular}

\subsubsection{Hiperimunização}

Após 58 dias da última sangria [item 4.3.2.4], foi realizada a sangria exploradora [item 4.3.2.2] dos 18 cavalos selecionados, tendo sido escolhido um único cavalo de cada grupo [Tabela 6] para receber a primeira dose de antígeno, a saber: cavalos $n^{\text {os }}$. 443, 215 e 326. Esses cavalos foram observados diariamente durante quatro dias, e por não terem apresentado sinais de intoxicação tetânica, no quinto dia o restante dos cavalos também recebeu a primeira dose do respectivo antígeno dando inicio ao esquema de hiperimunização propriamente dito, conforme expresso na Tabela 7. Todas as doses foram aplicadas subcutâneamente em um único ponto no dorso do animal. Em cada um dos dias de aplicação do antígeno foi realizada a 
sangria exploradora [item 4.3.2.2], sendo que no $28^{\circ}$ dia após a aplicação da primeira dose do esquema de hiperimunização foi realizada uma nova sangria exploradora, os soros foram individualmente testados quanto à concentração de anticorpos antitetânicos [item 4.2.12] e com base nos resultados obtidos, foram formados os subgrupos [item 4.3.2.7] para prosseguimento da imunização.

Tabela 7 - Esquema de hiperimunização e antígenos empregados

\begin{tabular}{|c|c|c|c|c|c|c|}
\hline GRUPO & ANTÍGENO & $\begin{array}{l}\text { PEGLAÇÃO } \\
\text { TEÓRICA }\end{array}$ & DOSE & DIA & $\begin{array}{l}\text { VOLUME } \\
(\mathrm{mL})\end{array}$ & $\begin{array}{c}\text { LF } \\
\text { TOTAL }\end{array}$ \\
\hline \multirow{4}{*}{1} & \multirow{4}{*}{$\begin{array}{c}\text { Toxina Tetânica } \\
\text { mPEG-SPA } \\
5.000\end{array}$} & $100 \%$ & $1^{\mathrm{a}}$. & 1 & 1,0 & 250 \\
\hline & & \multirow{3}{*}{$15 \%$} & $2^{\mathrm{a}}$. & 5 & 2,0 & 500 \\
\hline & & & $3^{\mathrm{a}}$. & 8 & 4,0 & 1.000 \\
\hline & & & $4^{\mathrm{a}}$. & 12 & 8,0 & 2.000 \\
\hline \multirow{4}{*}{2} & \multirow{4}{*}{$\begin{array}{c}\text { Toxina Tetânica } \\
\text { mPEG-SPA } \\
5.000(2 \mathrm{X})\end{array}$} & $200 \%$ & $1^{\mathrm{a}}$. & 1 & 1,0 & 250 \\
\hline & & \multirow{3}{*}{$30 \%$} & $2^{\mathrm{a}}$. & 5 & 2,0 & 500 \\
\hline & & & $3^{\mathrm{a}}$. & 8 & 4,0 & 1.000 \\
\hline & & & $4^{\mathrm{a}}$. & 12 & 8,0 & 2.000 \\
\hline \multirow{4}{*}{3} & \multirow{4}{*}{$\begin{array}{c}\text { Toxina Tetânica } \\
\text { Fluida }\end{array}$} & & $1^{\mathrm{a}}$. & 1 & 1,0 & 250 \\
\hline & & & $2^{\mathrm{a}}$. & 5 & 2,0 & 500 \\
\hline & & & $3^{\mathrm{a}}$. & 8 & 4,0 & 1.000 \\
\hline & & & $4^{\mathrm{a}}$. & 12 & 8,0 & 2.000 \\
\hline \multicolumn{7}{|c|}{ SANGRIA EXPLORADORA ( $\left(28^{\circ}\right.$ DIA) } \\
\hline
\end{tabular}

\subsubsection{Formação dos Subgrupos}

Com base na última sangria exploradora [item 4.3.2.6] foram formados 3 grupos principais, os quais foram divididos em outros dois grupos cada um deles com 3 cavalos, de acordo com a Tabela 8. 
Tabela 8 - Grupos e subgrupos de cavalos e antígenos empregados nos esquemas de hiperimunização

\begin{tabular}{|c|c|c|c|c|}
\hline GRUPO & SUBGRUPO & ANTÍGENO & $\begin{array}{c}\text { PEGLAÇÃO } \\
\text { TEÓRICA }\end{array}$ & $\begin{array}{c}\text { IDENTIFICAÇÃO } \\
\text { DO CAVALO }\end{array}$ \\
\hline \multirow{2}{*}{1} & $1 \mathrm{~A}$ & $\begin{array}{l}\text { Toxina Tetânica } \\
\text { mPEG-SPA } 5.000\end{array}$ & $50 \%$ & $\begin{array}{l}223 \\
340 \\
420 \\
\end{array}$ \\
\hline & $1 \mathrm{~B}$ & $\begin{array}{c}\text { Toxina Tetânica } \\
\text { mPEG-SPA } 5.000+ \\
\mathrm{Al}(\mathrm{OH})_{3}\end{array}$ & $50 \%$ & $\begin{array}{l}430 \\
433 \\
443\end{array}$ \\
\hline \multirow[b]{2}{*}{2} & $2 \mathrm{~A}$ & $\begin{array}{c}\text { Toxina Tetânica } \\
\text { mPEG-SPA } \\
5.000(2 \mathrm{X})\end{array}$ & $100 \%$ & $\begin{array}{l}215 \\
395 \\
469 \\
\end{array}$ \\
\hline & $2 \mathrm{~B}$ & $\begin{array}{c}\text { Toxina Tetânica } \\
\text { mPEG-SPA } \\
5.000(2 \mathrm{X})+ \\
\mathrm{Al}(\mathrm{OH})_{3} \\
\end{array}$ & $100 \%$ & $\begin{array}{l}427 \\
440 \\
464\end{array}$ \\
\hline \multirow{2}{*}{3} & $3 \mathrm{~A}$ & $\begin{array}{l}\text { Toxina Tetânica } \\
\text { Fluida }\end{array}$ & & $\begin{array}{l}391 \\
442 \\
465 \\
\end{array}$ \\
\hline & 3B & $\begin{array}{c}\text { Toxina Tetânica } \\
\text { Fluida }+\mathrm{Al}(\mathrm{OH})_{3}\end{array}$ & & $\begin{array}{l}326 \\
451 \\
454\end{array}$ \\
\hline
\end{tabular}

Após 40 dias da última sangria exploradora [item 4.3.2.6], foram escolhidos três cavalos para receber a primeira dose de antígeno, a saber: cavalos $\mathrm{n}^{\text {os }} 326,440$ e 443 . Estes animais foram observados diariamente durante três dias e, devido ao fato de não terem apresentado sinais de intoxicação tetânica, no quarto dia o restante dos cavalos recebeu também a primeira dose do respectivo antígeno, iniciando-se o ao esquema de primeira reimunização propriamente dito, conforme expresso na Tabela 9. As doses de 3,0; 6,0 e $12,0 \mathrm{~mL}$ foram aplicadas subcutâneamente em 2, 3 e 4 pontos, respectivamente, no dorso dos animais. Em cada um dos dias de aplicação dos antígenos foi realizada a sangria exploradora [item 4.3.2.2] e, no $26^{\circ}$ dia após a aplicação da primeira dose, foi realizada nova sangria exploradora [item 4.3.2.2]. 
Tabela 9 - Esquema de primeira reimunização e antígenos empregados

\begin{tabular}{|c|c|c|c|c|c|c|c|}
\hline GRUPO & SUBGRUPO & ANTÍGENO & $\begin{array}{c}\text { PEGLAÇÃO } \\
\text { TEÓRICA }\end{array}$ & DOSE & DIA & $\begin{array}{r}\text { VOLUME } \\
(\mathrm{mL}) \\
(\mathrm{mg}) \\
\end{array}$ & $\begin{array}{c}\text { Lf } \\
\text { TOTAL }\end{array}$ \\
\hline \multirow{6}{*}{1} & \multirow{3}{*}{$1 \mathrm{~A}$} & \multirow{3}{*}{$\begin{array}{c}\text { Toxina } \\
\text { Tetânica } \\
\text { mPEG-SPA } \\
5.000 \\
\end{array}$} & \multirow{3}{*}{$50 \%$} & $1^{\mathrm{a}}$. & 1 & 3 & 1.500 \\
\hline & & & & $2^{\mathrm{a}}$. & 4 & 6 & 6.000 \\
\hline & & & & $3^{\mathrm{a}}$ & 10 & 12 & 24.000 \\
\hline & \multirow[b]{3}{*}{ 1B } & \multirow{3}{*}{$\begin{array}{c}\text { Toxina } \\
\text { Tetânica } \\
\text { mPEG-SPA } \\
5.000+ \\
\mathrm{Al}(\mathrm{OH})_{3}\end{array}$} & \multirow[b]{3}{*}{$50 \%$} & $1^{\mathrm{a}}$. & 1 & 3 & 1.500 \\
\hline & & & & $2^{\mathrm{a}}$ & 4 & 6 & 6.000 \\
\hline & & & & $3^{\mathrm{a}}$. & 10 & 12 & 24.000 \\
\hline \multirow{6}{*}{2} & \multirow{3}{*}{$2 \mathrm{~A}$} & \multirow{3}{*}{$\begin{array}{c}\text { Toxina } \\
\text { Tetânica } \\
\text { mPEG-SPA } \\
5.000(2 \mathrm{X}) \\
\end{array}$} & \multirow{3}{*}{$100 \%$} & $1^{\mathrm{a}}$. & 1 & 3 & 1.500 \\
\hline & & & & $2^{\mathrm{a}}$ & 4 & 6 & 6.000 \\
\hline & & & & $3^{\mathrm{a}}$ & 10 & 12 & 24.000 \\
\hline & \multirow[b]{3}{*}{$2 \mathrm{~B}$} & \multirow{3}{*}{$\begin{array}{c}\text { Toxina } \\
\text { Tetânica } \\
\text { mPEG-SPA } \\
5.000(2 \mathrm{X})+ \\
\mathrm{Al}(\mathrm{OH})_{3}\end{array}$} & \multirow[b]{3}{*}{$100 \%$} & $1^{\mathrm{a}}$. & 1 & 3 & 1.500 \\
\hline & & & & $2^{\mathrm{a}}$ & 4 & 6 & 6.000 \\
\hline & & & & $3^{\mathrm{a}}$. & 10 & 12 & 24.000 \\
\hline \multirow{6}{*}{3} & \multirow{3}{*}{$3 \mathrm{~A}$} & \multirow{3}{*}{$\begin{array}{l}\text { Toxina } \\
\text { Tetânica } \\
\text { Fluida }\end{array}$} & & $1^{\mathrm{a}}$. & 1 & 3 & 1.500 \\
\hline & & & & $2^{\mathrm{a}}$ & 4 & 6 & 6.000 \\
\hline & & & & $3^{\mathrm{a}}$ & 10 & 12 & 24.000 \\
\hline & \multirow{3}{*}{$3 \mathrm{~B}$} & \multirow{3}{*}{$\begin{array}{l}\text { Toxina } \\
\text { Tetânica } \\
\text { Fluida }+ \\
\mathrm{Al}(\mathrm{OH})_{3}\end{array}$} & & $1^{\mathrm{a}}$. & 1 & 3 & 1.500 \\
\hline & & & & $2^{\mathrm{a}}$ & 4 & 6 & 6.000 \\
\hline & & & & $3^{\mathrm{a}}$. & 10 & 12 & 24.000 \\
\hline \multicolumn{8}{|c|}{ SANGRIA EXPLORADORA ( $26^{\circ}$ DIA) } \\
\hline
\end{tabular}

O segundo esquema de reimunização, expresso na Tabela 10, foi iniciado após 48 dias da última sangria exploradora [item 4.3.2.7]. As doses de 3,0;6,0 e $12 \mathrm{~mL}$ foram aplicadas subcutâneamente em 2, 3 e 4 pontos, respectivamente, no dorso dos cavalos. Em cada um dos dias de aplicação dos antígenos realizou-se a sangria exploradora [item 4.3.2.2] e, no $35^{\circ}$ dia após a aplicação da primeira dose de antígeno, foi realizada a última sangria exploradora [item 4.3.2.2], da qual as amostras foram analisadas individualmente pelo ToBI Teste [item 4.2.12] e também por Imunodifusão [item 4.2.13]. Pool das amostras dos soros de cada um dos grupos de cavalos descritos na Tabela 10 foram analisados por immunoblotting [item 4.2.15]. 
Tabela 10 - Segundo esquema de reimunização e antígenos empregados

\begin{tabular}{|c|c|c|c|c|c|c|c|}
\hline GRUPO & SUBGRUPO & ANTÍGENO & $\begin{array}{c}\text { PEGLAÇÃO } \\
\text { TEÓRICA }\end{array}$ & DOSE & DIA & 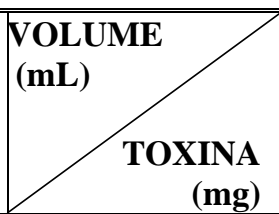 & $\begin{array}{c}\text { Lf } \\
\text { TOTAL }\end{array}$ \\
\hline \multirow{8}{*}{1} & \multirow{4}{*}{$1 \mathrm{~A}$} & \multirow{4}{*}{$\begin{array}{c}\text { Toxina } \\
\text { Tetânica } \\
\text { mPEG-SPA } \\
5.000\end{array}$} & \multirow{4}{*}{$50 \%$} & $1^{a^{a}}$. & $\overline{11}$ & 3 & $\begin{array}{l}1.500 \\
\end{array}$ \\
\hline & & & & $2^{\mathrm{a}}$ & 6 & 3 & 1.500 \\
\hline & & & & $3^{\mathrm{a}}$. & 16 & 6 & 6.000 \\
\hline & & & & $4^{\mathrm{a}}$. & 24 & 12 & 24.000 \\
\hline & \multirow{4}{*}{ 1B } & \multirow{4}{*}{$\begin{array}{c}\text { Toxina } \\
\text { Tetânica } \\
\text { mPEG-SPA } \\
5.000+ \\
\mathrm{Al}(\mathrm{OH})_{3}\end{array}$} & \multirow{4}{*}{$50 \%$} & $1^{\mathrm{a}}$. & 1 & 3 & 1.500 \\
\hline & & & & $2^{\mathrm{a}}$. & 6 & 3 & 1.500 \\
\hline & & & & $3^{\mathrm{a}}$ & 16 & 6 & 6.000 \\
\hline & & & & $4^{\mathrm{a}}$. & 24 & 12 & 24.000 \\
\hline \multirow{8}{*}{2} & \multirow{4}{*}{$2 \mathrm{~A}$} & \multirow{4}{*}{$\begin{array}{c}\text { Toxina } \\
\text { Tetânica } \\
\text { mPEG-SPA } \\
5.000(2 \mathrm{X}) \\
\end{array}$} & \multirow{4}{*}{$100 \%$} & $1^{\mathrm{a}}$. & 1 & 3 & 1.500 \\
\hline & & & & $2^{\mathrm{a}}$. & 6 & 3 & 1.500 \\
\hline & & & & $3^{\mathrm{a}}$. & 16 & 6 & 6.000 \\
\hline & & & & $4^{\mathrm{a}}$. & 24 & 12 & 24.000 \\
\hline & \multirow{4}{*}{$2 \mathrm{~B}$} & \multirow{4}{*}{$\begin{array}{c}\text { Toxina } \\
\text { Tetânica } \\
\text { mPEG-SPA } \\
5.000(2 \mathrm{X})+ \\
\mathrm{Al}(\mathrm{OH})_{3}\end{array}$} & \multirow{4}{*}{$100 \%$} & $1^{\mathrm{a}}$. & 1 & 3 & 1.500 \\
\hline & & & & $2^{\mathrm{a}}$ & 6 & 3 & 1.500 \\
\hline & & & & $3^{\mathrm{a}}$ & 16 & 6 & 6.000 \\
\hline & & & & $4^{\mathrm{a}}$. & 24 & 12 & 24.000 \\
\hline \multirow{8}{*}{3} & \multirow{4}{*}{$3 \mathrm{~A}$} & \multirow{4}{*}{$\begin{array}{l}\text { Toxina } \\
\text { Tetânica } \\
\text { Fluida }\end{array}$} & & $1^{\mathrm{a}}$. & 1 & 3 & 1.500 \\
\hline & & & & $2^{\mathrm{a}}$ & 6 & 3 & 1.500 \\
\hline & & & & $3^{\mathrm{a}}$ & 16 & 6 & 6.000 \\
\hline & & & & $4^{\mathrm{a}}$. & 24 & 12 & 24.000 \\
\hline & \multirow{4}{*}{$3 B$} & \multirow{4}{*}{$\begin{array}{l}\text { Toxina } \\
\text { Tetânica } \\
\text { Fluida }+ \\
\mathrm{Al}(\mathrm{OH})_{3}\end{array}$} & & $1^{\mathrm{a}}$. & 1 & 3 & 1.500 \\
\hline & & & & $2^{\mathrm{a}}$. & 6 & 3 & 1.500 \\
\hline & & & & $3^{\mathrm{a}}$. & 16 & 6 & 6.000 \\
\hline & & & & $4^{\mathrm{a}}$. & 24 & 12 & 24.000 \\
\hline
\end{tabular}

Ao término dos esquemas de hiperimunização, extraiu-se de cada cavalo, por punção jugular, em média 6 litros de sangue e se aplicou o sistema de plasmaferese. O sangue foi colhido em bolsas plásticas duplas e interligadas, com capacidade para 6 litros, das quais a primeira bolsa continha $400 \mathrm{~mL}$ de solução anticoagulante $(5,29 \%$ de dextrose, $4,75 \%$ de citrato de sódio e $1,72 \%$ de ácido cítrico). As bolsas foram esterilizadas pelo fabricante por radiação gama de cobalto. Imediatamente após a coleta, as bolsas foram armazenadas de $2{ }^{\circ} \mathrm{C}$ a $8 \mathrm{C}$ e o plasma foi transferido após 24 horas para segunda bolsa. As hemácias que permaneceram na primeira bolsa foram ressuspensas com $1.000 \mathrm{~mL}$ de solução salina $0,85 \%$ esterilizada por filtração $(0,22 \mu \mathrm{m})$ e a suspensão foi reinoculada pela veia jugular no mesmo animal doador. A reinfusão das hemácias foi completada em aproximadamente 20 minutos. $\mathrm{O}$ plasma foi enviado para a Seção de Processamento de Plasmas Hiperimunes do Serviço de Imunologia da Divisão de Desenvolvimento Tecnológico e Produção do Instituto Butantan onde foi tratado com pepsina e purificado por desnaturação pelo calor e precipitação por sulfato de amônio segundo os procedimentos em vigor no Instituto Butantan. 


\section{RESULTADOS E DISCUSSÃO}

O soro antitetânico produzido pelo Instituto Butantan, empregado na profilaxia e tratamento do tétano humano, é obtido através da hiperimunização de eqüinos seguindo esquemas de imunização que utilizam a Toxina Tetânica [item 4.1.2] e a Anatoxina Tetânica [item 4.1.5], ambas produzidas no Instituto. A toxina tetânica é obtida por processo fermentativo [item 4.1.2]; já a anatoxina tetânica, aplicada no início do esquema de hiperimunização, é a toxina destoxificada pela ação do formaldeído e do calor [item 4.1.4], conforme a técnica estabelecida por Lemos Monteiro na década de 20 (MONTEIRO, 1925) e, desde então, utilizada no Instituto Butantan. Destaque-se que a toxina tetânica destoxificada é um produto absolutamente atóxico, imunogênico, de características antigênicas comparáveis à toxina original (BIER, 1978a). Após a destoxificação, a anatoxina tetânica é purificada utilizando técnica desenvolvida no Instituto Butantan (PRADO et al., 1999), que consiste na concentração do produto por filtração tangencial em membrana de $50 \mathrm{kDa}$ e posterior cromatografia de gel filtração em resina Sephacryl S-200 HR [item 4.1.5].

Nesse estudo, visando à conjugação da toxina tetânica com mPEG-SPA e sua utilização como antígeno nos estudos de imunização de cavalos e cobaias, houve a necessidade de purificar a Toxina Tetânica Concentrada. Para tanto, aprimorou-se uma técnica empregada para purificação da anatoxina tetânica que consistia na precipitação por sulfato de amônio, duas centrifugações e concentração por filtração tangencial em membrana de 10 kDa (PRADO et al., 1992, 1993). Assim, ao invés de purificar a anatoxina tetânica, purificou-se a toxina tetânica e, com base na constatação de que a toxina possui massa molecular igual a 150 kDa (RAPPUOLI, 1997; TURTON et al., 2002; LALLI et al., 2003), substituiu-se a membrana de ultrafiltração molecular de $10 \mathrm{kDa}$ por uma de $100 \mathrm{kDa}$ que, além de eliminar um número maior de moléculas pequenas, de impurezas ou contaminantes, diminuiu o tempo empregado nesse procedimento. Por conseguinte, minimizou-se o aquecimento do produto durante o procedimento de concentração, o que contribui sobremaneira para a degradação da proteína. Além disso, concentrou-se a toxina tetânica para volumes pequenos facilitando o tratamento subseqüente à filtração, ou seja, pelo mPEG-SPA. Ainda, pode-se citar como vantagem da metodologia adotada para purificação a viabilidade de sua aplicação na rotina de produção, vale dizer, a realização do procedimento de purificação em escala industrial, o que é de interesse da Instituição.

A avaliação do índice de purificação foi realizada com base no valor referente ao grau de pureza antigênica (Lf/mgNP) [item 4.2.4] e, segundo critérios estabelecidos pela WHO 
(1977), a Anatoxina Tetânica [Produto Acabado a Granel] somente pode ser utilizada na formulação de vacinas para uso humano quando igual ou superior a $1.000 \mathrm{Lf} / \mathrm{mgNP}$. Assim, a utilização de um índice adotado para produção de vacinas aplicadas em seres humanos foi suficiente para selecionar uma toxina tetânica destinada à imunização de cavalos. Ressalte-se que nos esquemas rotineiros de hiperimunização de cavalos soroprodutores no Instituto Butantan, a Toxina Tetânica Concentrada é utilizada no preparo dos antígenos sem qualquer etapa posterior de purificação e/ou adoção de critério mínimo de pureza antigênica, sendo que nos processos de produção obtém-se, na prática, o valor médio de 560 Lf/mgNP.

A partir da metodologia empregada para purificação da Toxina Tetânica Concentrada o grau de pureza antigênica (produto inicial), que era de 327,87 Lf/mgNP, elevou-se para 1.256,83 Lf/mgNP. A Tabela 11 expressa as principais características da toxina tetânica antes e após a etapa de purificação.

Tabela 11 - Valores comparativos determinados através de testes físico-químicos e biológico para a Toxina Tetânica Concentrada e Toxina Tetânica Purificada

\begin{tabular}{l|r|r}
\hline \multirow{2}{*}{\multicolumn{1}{c|}{ TESTES }} & \multicolumn{2}{|c}{ TOXINA TETÂNICA } \\
\cline { 2 - 3 } & CONCENTRADA & \multicolumn{1}{c}{ PURIFICADA } \\
\hline \hline $\mathrm{pH}$ & 7,4 & 7,2 \\
\hline Nitrogênio Protéico & $1,83 \mathrm{mg} \mathrm{NP} / \mathrm{mL}$ & $1,83 \mathrm{mg} \mathrm{NP} / \mathrm{mL}$ \\
\hline Limite de Floculação & $600 \mathrm{Lf} / \mathrm{mL}$ & $2300 \mathrm{Lf} / \mathrm{mL}$ \\
\hline Pureza Antigênica & $327,87 \mathrm{Lf} / \mathrm{mgNP}$ & $1256,83 \mathrm{Lf} / \mathrm{mgNP}$ \\
\hline Sulfato de Amônio & & $<200 \mathrm{ppm}$ \\
\hline DL & & $1 / 1.802 .412$ \\
\hline \hline
\end{tabular}

\subsection{Grau de PEGlação da Toxina Tetânica Modificada pelo mPEG-SPA}

O monitoramento do grau de PEGlação da toxina tetânica requereu a elaboração de uma curva padrão [Figura 18] a partir de concentrações diferentes da Toxina Tetânica Purificada [item 4.1.3], cuja concentração em $\mathrm{mg} / \mathrm{mL}$ foi determinada através do método de Bradford (1976) [item 4.2.5], e estão expressas na Tabela 12. Após análise colorimétrica pelo método de TNBS (HABBEB, 1966) [item 4.2.1], foram quantificadas as aminas livres da toxina tetânica capazes de reagir com o TNBS. Após a reação de modificação, o grau de PEGlação foi calculado a partir da diferença entre a porcentagem das aminas livres da Toxina Tetânica Purificada não conjugada e a porcentagem de aminas livres das amostras de Toxina Tetânica conjugadas ao mPEG-SPA [Tabela 13]. 
Tabela 12 - Valores de absorbância (em 435 nm) da Toxina Tetânica Purificada

\begin{tabular}{c|c}
\hline \hline $\begin{array}{c}\text { CONCENTRAÇÕES DE } \\
\text { TOXINA TETÂNICA } \\
\text { (mg/mL) }\end{array}$ & $\begin{array}{c}\text { ABSORBÂNCIAS } \\
\text { (As) }\end{array}$ \\
\hline \hline 0,10 & 0,11 \\
\hline 0,20 & 0,21 \\
\hline 0,30 & 0,31 \\
\hline 0,40 & 0,41 \\
\hline 0,50 & 0,47 \\
\hline 0,60 & 0,57 \\
\hline 0,70 & 0,65 \\
\hline 0,80 & 0,71 \\
\hline 0,90 & 0,79 \\
\hline \hline
\end{tabular}

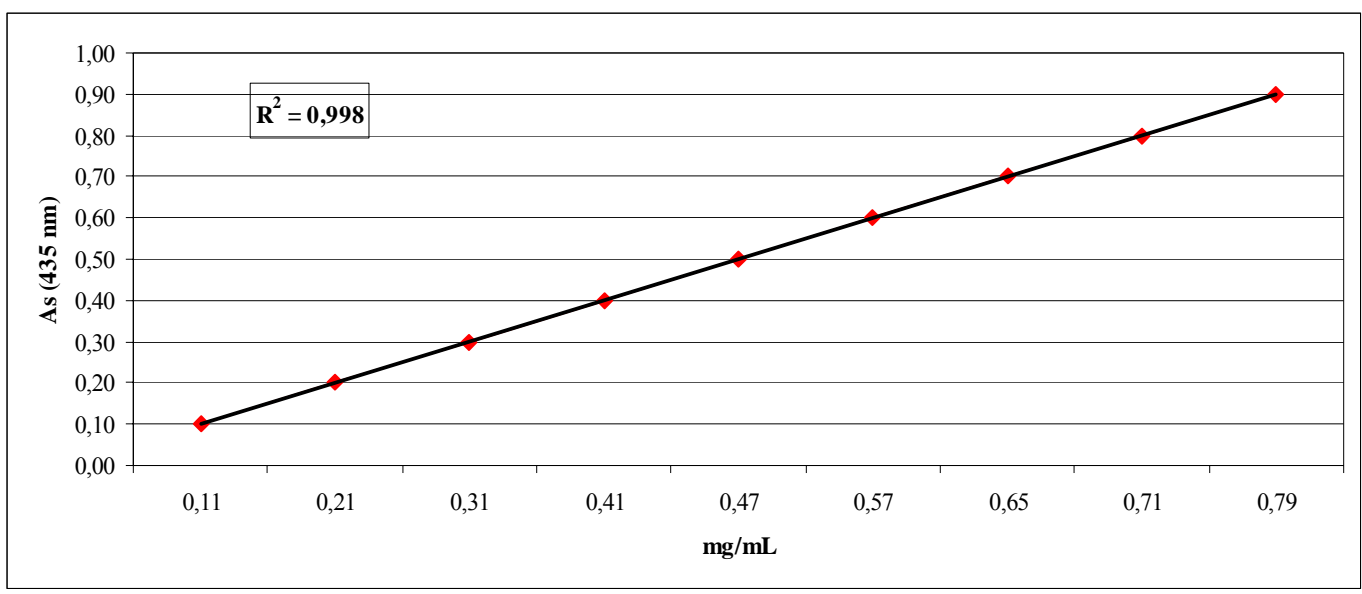

Figura 18 - Correlação (r) entre os valores de concentração cujos dados acham-se apresentados na Tabela 12.

Definir o grau de PEGlação das proteínas, e no caso da Toxina Tetânica Purificada tratada com o mPEG-SPA, é fator indispensável à mensuração da intensidade residual de suas atividades biológicas, como relata a literatura referente ao nível de PEGlação, atividade biológica e imunogenicidade de biofármacos (MATSUSHIMA et al., 1996; SO et al., 1999). Ressalte-se que no presente estudo a conjugação da toxina tetânica pelo mPEG-SPA 5.000 e mPEG-SPA 20.000 tem por objetivo minimizar a atividade neurotóxica da proteína em razão do aumento da concentração desses polímeros.

Como observado nas Figuras 3 a 5 [item 2 - Revisão da Literatura], a toxina tetânica possui 33 lisinas em sua cadeia leve e 66 na pesada, totalizando 99 lisinas. Neste estudo estabeleceu-se as proporções de mPEG-SPA e toxina tetânica com base na proporção da quantidade de radicais passíveis de reagir com o mPEG-SPA dentro de uma proporção molecular entre a proteína (toxina tetânica) e o polímero. Considerando-se que cada molécula 
de toxina tetânica possui 99 lisinas, quando o grau de PEGlação corresponder a 40\%, como no caso da amostra TxTmPEG-SPA5/40, significará que aproximadamente 40 lisinas foram conjugadas ao mPEG-SPA 5.000 ou, no caso da amostra TxTmPEG-SPA20/10, refletirá que aproximadamente 10 lisinas foram conjugadas ao mPEG-SPA 20.000, e assim sucessivamente.

Tabela 13 - Grau de sítios de amina conjugada ao mPEG-SPA 5.000 e mPEG-SPA 20.000

\begin{tabular}{|c|c|c|c|}
\hline mPEG-SPA (Da) & $\begin{array}{c}\text { PEGLAÇÃO } \\
\text { TEÓRICA }\end{array}$ & $\begin{array}{l}\text { PORCENTAGEM } \\
\text { DE PEGLAÇÃO }\end{array}$ & DENOMINAÇÃO \\
\hline \multirow{6}{*}{ Toxina Tetânica mPEG-SPA 5.000} & $100 \%$ & $40 \%$ & TxTmPEG-SPA5/40 \\
\hline & $60 \%$ & $31 \%$ & TxTmPEG-SPA5/31 \\
\hline & $50 \%$ & $25 \%$ & TxTmPEG-SPA5/25 \\
\hline & $30 \%$ & $14 \%$ & TxTmPEG-SPA5/14 \\
\hline & $15 \%$ & $4 \%$ & TxTmPEG-SPA5/4 \\
\hline & $6 \%$ & $0 \%$ & TxTmPEG-SPA5 \\
\hline \multirow{6}{*}{$\begin{array}{l}\text { Toxina Tetânica mPEG-SPA } \\
5.000(2 \mathrm{X})\end{array}$} & $200 \%$ & $50 \%$ & TxTmPEG-SPA5(2X)/50 \\
\hline & $120 \%$ & $40 \%$ & TxTmPEG-SPA5(2X)/40 \\
\hline & $100 \%$ & $38 \%$ & TxTmPEG-SPA5(2X)/38 \\
\hline & $60 \%$ & $32 \%$ & TxTmPEG-SPA5(2X)/32 \\
\hline & $30 \%$ & $16 \%$ & TxTmPEG-SPA5(2X)/16 \\
\hline & $12 \%$ & $0 \%$ & TxTmPEG-SPA5(2X) \\
\hline \multirow{5}{*}{ Toxina Tetânica mPEG-SPA 20.000} & $100 \%$ & $31 \%$ & TxTmPEG-SPA20/31 \\
\hline & $60 \%$ & $17 \%$ & TxTmPEG-SPA20/17 \\
\hline & $30 \%$ & $10 \%$ & TxTmPEG-SPA20/10 \\
\hline & $15 \%$ & $7 \%$ & TxTmPEG-SPA20/7 \\
\hline & $6 \%$ & $2 \%$ & TxTmPEG-SPA20/2 \\
\hline \multirow{5}{*}{$\begin{array}{l}\text { Toxina Tetânica mPEG-SPA } \\
\qquad 20.000(2 \mathrm{X})\end{array}$} & $200 \%$ & $33 \%$ & TxTmPEG-SPA20(2X)/33 \\
\hline & $120 \%$ & $31 \%$ & TxTmPEG-SPA20(2X)/31 \\
\hline & $60 \%$ & $16 \%$ & TxTmPEG-SPA20(2X)/16 \\
\hline & $30 \%$ & $10 \%$ & TxTmPEG-SPA20(2X)/10 \\
\hline & $12 \%$ & $5 \%$ & TxTmPEG-SPA20(2X)/5 \\
\hline
\end{tabular}

NOTAS: TxTmPEG-SPA = Toxina Tetânica conjugada ao mPEG-SPA:

TxTmPEG-SPA5/40 = mPEG-SPA 5.000 com 40\% de PEGglação da toxina tetânica; TxTmPEG-SPA5(2X)/50 = mPEG-SPA 5.000 (ao dobro) com 50\% de PEGlação da toxina tetânica; TxTmPEG-SPA20/31 = mPEG-SPA 20.000 com 31\% de PEGlação da toxina tetânica; TxTmPEG-SPA20(2X)/33 = mPEG-SPA 20.000 (ao dobro) com 33\% de PEGlação da toxina tetânica e assim sucessivamente.

O método do TNBS (HABEEB, 1966) é amplamente empregado na determinação de aminas livres derivadas de lisina e, em situações específicas como descrito por Bullock e colaboradores (1997), no qual se estudou a modificação da enzima superóxido dismutase pelo PEG ativado, o método de TNBS superestimou a real porcentagem de modificação do mPEG. As justificativas apresentadas estão relacionadas às falhas inerentes ao próprio método e à possibilidade de haver lisinas bloqueadas não conjugadas ao $\mathrm{mPEG}$; isso porque o grupo 
E-amino ainda se encontra na forma de amida resultante de uma reação onde a lisina conjugada ao mPEG foi hidrolisada, sendo que o método de TNBS apenas detecta as lisinas íntegras e não conjugadas. Ressalte-se que o mesmo autor afirma que, segundo estudos realizados, a técnica que emprega o TNBS é um procedimento amplamente utilizado para caracterização, sendo ainda o método padrão utilizado em muitos laboratórios para quantificação da conjugação pelo mPEG. Ademais, trata-se de um teste prático, rápido e que necessita de pouca sofisticação, sendo suficiente para detectar diferenças de grau de PEGlação entre diferentes concentrações de mPEG, conferindo uma noção comparativa da presença de mPEG complexado à proteína. Diante do relatado por Bullock e colaboradores (1997) sugerese que o grau de sítios de aminas conjugadas ao mPEG-SPA seja menor do que aquele mensurado pela reação com o TNBS, cujos valores estão especificados na Tabela 13.

Os perfis de proteínas das amostras de toxina tetânica conjugada ao mPEG-SPA foram analisados por meio de ensaio em gel de acrilamida [SDS-PAGE] a uma concentração de $10 \%$ para o gel de corrida e de 5\% para o gel de empilhamento, sendo que as amostras foram aplicadas no substrato na concentração de $1 \mathrm{mg} / \mathrm{mL}$. No perfil eletroforético, apresentado na Figura 19, observa-se nas amostras de toxina tetânica conjugadas ao mPEGSPA 5.000 que, com a diminuição do grau de PEGlação, as primeiras bandas das linhas 2 a 5 do gel apresentam um decréscimo de sua massa molecular. É possível verificar que na linha 6 a amostra, que teoricamente deveria ter um grau de PEGlação correspondente a $6 \%$ TxTmPEG-SPA5 e que de acordo com o resultados obtido no método de TNBS não foi complexada ao mPEG-SPA, apresenta perfil semelhante à linha 7, que corresponde à amostra de toxina tetânica de $1 \mathrm{mg}$. Tal constatação parece demonstrar que o método do TNBS não apresentou resultados superestimados como aqueles encontrados por Bullock e colaboradores (1997), uma vez que as amostras não PEGladas devem ter perfis similares à toxina tetânica não conjugada ao mPEG.

O géis de eletroforese cujas amostras de toxina tetânica foram conjugadas ao mPEGSPA 5.000(2X), mPEG-SPA 20.000 e mPEG-SPA 20.000(2X), não estão representados devido ao fato de terem apresentado problemas quanto à imagem da separação da toxina tetânica PEGlada, visto que as bandas mostraram-se dispersas, pouco nítidas e algumas até manchadas, conforme também verificado por Zheng e colaboradores (2007). Os rastros que foram observados nos géis podem ser explicados pela alteração do perfil hidrodinâmico das proteínas PEGladas; entretanto, o ensaio em SDS-PAGE, nesse caso, é um teste qualitativo e um modo prático de verificar se a PEGlação está ocorrendo. Mais ainda, o fato das amostras 
terem sido fervidas e colocadas na presença de 2-mercaptoetanol [item 4.2.14] sugere que a ligação mPEG-toxina ocorre por uma reação covalente forte e estável.

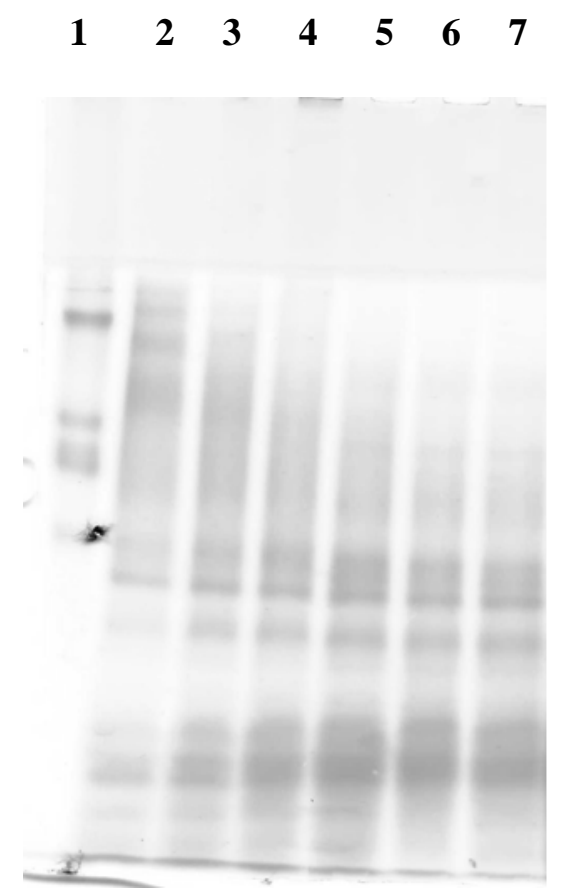

Figura 19 - Eletroforese em gel de Acrilamida (SDS-PAGE) em concentração de 10\% de acrilamida e coloração com Coomassie Blue $250 \mathrm{R}$. Amostras de toxina tetânica tratadas com 2-mercaptoetanol. Linha 1 - Padrão de massa molecular High Molecular Weight; linha 2 - TxTmPEG-SPA5/40; linha 3 - TxTmPEG-SPA5/31; linha 4 - TxTmPEG-SPA5/14; linha 5 - TxTmPEG-SPA5/4; linha 6 - TxTmPEG-SPA5; linha 7 - toxina $1 \mathrm{mg}$.

\subsection{Estudo Comparativo da Via de Inoculação}

Visando à realização dos experimentos relacionados à interferência da via de inoculação quanto ao efeito adjuvante do mPEG-SPA, foi necessário, primeiramente, imunizar as cobaias contra o tétano, pois, caso as amostras de toxina tetânica conjugadas ou não pelo mPEG-SPA fossem inoculadas diretamente, efeitos tóxicos poderiam ser provocados inviabilizando o estudo (conforme verificado no ensaio Dose Letal 50\%). Assim, todo o grupo foi imunizado com Toxóide Tetânico na concentração e volume estabelecidos para o teste de determinação da atividade antigênica [item 4.2.10] (WORLD HEALTH ORGANIZATION, 1977; BRASIL, 1996, 1998). Os antígenos experimentais foram inoculados após 21 dias da vacinação para indução de resposta secundária. 
$\mathrm{Na}$ Tabela 14 estão descritas as características da Anatoxina Tetânica [Produto Acabado a Granel] empregada na formulação do Toxóide Tetânico utilizado nas imunizações.

Tabela 14 - Características físico-químicas e biológica da Anatoxina Tetânica Produto Acabado a Granel e do Toxóide Tetânico

\begin{tabular}{|c|c|c|}
\hline TESTES & $\begin{array}{c}\text { ANATOXINA } \\
\text { TETÂNICA }\end{array}$ & TOXÓIDE TETÂNCO \\
\hline $\mathrm{pH}$ & 6,4 & 6,5 \\
\hline Timerosal & $135,34 \mathrm{ppm}$ & $130,87 \mathrm{ppm}$ \\
\hline Alumínio & & $0,38 \mathrm{mg} / \mathrm{dose}$ \\
\hline Formaldeído residual & $13,67 \mathrm{ppm}$ & $0,92 \mathrm{ppm}$ \\
\hline Cloreto de sódio & $0,74 \mathrm{~g} \%$ & \\
\hline Nitrogênio total & $1,48 \mathrm{mg} / \mathrm{mL}$ & \\
\hline Nitrogênio protéico & $1,22 \mathrm{mg} / \mathrm{mL}$ & \\
\hline Nitrogênio não protéico & $0,26 \mathrm{mg} / \mathrm{mL}$ & \\
\hline Pureza antigênica & $1.639,34 \mathrm{Lf} / \mathrm{mgNP}$ & \\
\hline Limite floculante & $2.000 \mathrm{Lf} / \mathrm{mL}$ & $20 \mathrm{Lf} / \mathrm{mL}$ \\
\hline Aspecto & Límpido & Suspensão opalescente \\
\hline Atividade imunogênica (10 Lf/dose) & $12,0 \mathrm{UI} / \mathrm{mL}$ & $3,0 \mathrm{UI} / \mathrm{mL}$ \\
\hline
\end{tabular}

Nota: dose $=0,5 \mathrm{~mL}$.

O grau de pureza antigênica de 1.639,34 Lf/mg NP alcançado pela Anatoxina Tetânica [PAG] é superior ao valor preconizado pelas normas estabelecidas para formulação do Toxóide Tetânico, de 1.000 Lf/mgNP (WORLD HEALTH ORGANIZATION, 1977; BRASIL, 1996). Na prova de atividade imunogênica a Anatoxina apresentou o valor de 12,0 $\mathrm{UI} / \mathrm{mL}$ e o Toxóide de 3,0 UI/mL, valores superiores ao mínimo de 2,0 UI/mL estabelecido pela WHO (1977) e pelas Normas Nacionais (BRASIL, 1996), sendo considerados adequados para o estudo por apresentaram os requisitos necessários para uso humano.

As características da Toxina Tetânica Fluida e Toxina Tetânica Fluida e Adsorvida pelo gel de $\mathrm{Al}(\mathrm{OH})_{3}$ estão expressas na Tabela 15 .

Tabela 15 - Características físico-químicas e biológica da TxT

\begin{tabular}{|c|c|c|}
\hline \multirow{2}{*}{ TESTES } & TxT FLUIDA & TxT ADSORVIDA \\
\hline & \multicolumn{2}{|c|}{ RESULTADOS } \\
\hline$\overline{\mathrm{pH}}$ & $\overline{77,5}$ & $\overline{7,1}$ \\
\hline Nitrogênio protéico & $0,22 \mathrm{mg} \mathrm{NP} / \mathrm{mL}$ & \\
\hline Limite de floculação & $210 \mathrm{Lf} / \mathrm{mL}$ & \\
\hline Pureza antigênica & $954,55 \mathrm{Lf} / \mathrm{mgNP}$ & \\
\hline Sulfato de amônio & $<200 \mathrm{ppm}$ & \\
\hline $\mathrm{DL}_{50}$ & $1 / 775.194$ & $1 / 729.927$ \\
\hline Alumínio & & $0,61 \mathrm{mg} / \mathrm{mL}$ \\
\hline
\end{tabular}


A fim de analisar a toxina tetânica tratada pelo mPEG-SPA 5.000 e mPEG-SPA 20.000, selecionou-se as amostras TxTmPEG-SPA5/40 e TxTmPEG-SPA5, e as amostras TxTmPEG-SPA20/31 e TxTmPEG-SPA20/5, por representarem duas condições distintas de conjugação, de maior e menor grau de PEGlação.

A interferência da via de inoculação no efeito adjuvante também foi verificada com amostras de Toxina Tetânica Fluida ou Adsorvida pelo gel de $\mathrm{Al}(\mathrm{OH})_{3}$; e PBS, Toxóide Tetânico (TT) e Toxina Tetânica Fluida como controles. Os resultados expressos na Tabela 16 demonstram que a toxina tetânica conjugada ao mPEG-SPA pela via subcutânea favorece a absorção, não só quando existe um aumento do tamanho do polímero, mas em função da concentração. Já o efeito adjuvante do gel de $\mathrm{Al}(\mathrm{OH})_{3}$ foi evidenciado quando as amostras foram aplicadas por via intramuscular. Ressalte-se que o valor de $34,5 \mathrm{UI} / \mathrm{mL}$ foi o maior título de antitoxina tetânica circulante e correspondeu à amostra TxTmPEG-SPA20/31 aplicada pela administração subcutânea. O título de $9,1 \mathrm{UI} / \mathrm{mL}$, considerado o menor dentre as amostras analisadas, refere-se à amostra TxTmPEG-SPA20/5 aplicada por via intramuscular, e todas as amostras, com exceção do PBS, apresentaram valores superiores a 2,0 UI/mL.

Tabela 16 - Títulos de anticorpos anti-TxT e vias de inoculação

\begin{tabular}{c|c|c}
\hline \hline AMOSTRA & VIA & UI/mL \\
\hline \multirow{2}{*}{ PBS } & subcutânea & $<0,3$ \\
\cline { 2 - 3 } & intramuscular & $<0,5$ \\
\hline \multirow{2}{*}{ Toxóide Tetânico (TT) } & subcutânea & 19,6 \\
\cline { 2 - 3 } & intramuscular & 26,3 \\
\hline \multirow{2}{*}{ Toxina Tetânica Fluida } & subcutânea & 15,3 \\
\cline { 2 - 3 } & intramuscular & 23,1 \\
\hline \multirow{2}{*}{ Toxina Tetânica Fluida e Adsorvida pelo Gel de Al(OH) 3} & subcutânea & 16,7 \\
\cline { 2 - 3 } & intramuscular & 18,5 \\
\hline \multirow{2}{*}{ TxTmPEG-SPA5/40 } & subcutânea & 19,2 \\
\cline { 2 - 3 } & intramuscular & 11,8 \\
\cline { 2 - 3 } TxTmPEG-SPA5 & subcutânea & 10,7 \\
\cline { 2 - 3 } & intramuscular & 14,0 \\
\cline { 2 - 3 } TxTmPEG-SPA20/31 & subcutânea & 34,5 \\
\cline { 2 - 3 } & intramuscular & 12,0 \\
\cline { 2 - 3 } & intramuscular & 17,0 \\
\hline \multirow{2}{*}{ TxTmPEG-SPA20/5 } & & \\
&
\end{tabular}

\subsection{Caracterização dos Antígenos Conjugados ao mPEG-SPA}

O método de floculação de Ramon (BIER, 1978b) é rápido e útil para avaliar toxinas, anatoxinas e antitoxinas durante os processos de preparação ou imunização. Aqui, as amostras de toxina tetânica foram submetidas ao teste de determinação do limite de floculação 
objetivando-se aferir os títulos e estabelecer a relação ótima em que ocorre a neutralização da toxina pelo respectivo antisoro; é também importante verificar a velocidade $[\mathrm{Kf}]$ com que essa reação ocorre. Os resultados para as amostras descritas na Tabela 17 ficaram na faixa de $200 \mathrm{Lf} / \mathrm{mL} \pm 10 \mathrm{Lf} / \mathrm{mL}$, com Kf de $10 \pm 5$ minutos. Não foram observadas variações relacionadas ao aumento da massa molecular ou à concentração do mPEG-SPA. Deve-se ressaltar que os títulos encontrados estão de acordo com o esperado, já que são similares ao valor de $210 \mathrm{Lf} / \mathrm{mL}$ determinado para a amostra da Toxina Tetânica Fluida [Tabela 15].

No que diz respeito à toxicidade, tanto as amostras de toxina tetânica conjugadas ao mPEG-SPA 5.000 e 20.000 como aquelas não conjugadas foram avaliadas através da Dose Letal 50\% [Tabela 17 e Figuras 20 a 23].

Tabela 17 - DL Do $_{50}$ das TxTmPEG-SPA

\begin{tabular}{c|c}
\hline $\begin{array}{c}\text { DESCRIÇÃO DAS AMOSTRAS } \\
\text { TxTmPEG-SPA }\end{array}$ & DL $_{\mathbf{5 0}}$ \\
\hline \hline $5 / 40$ & $1 / 11.177$ \\
\hline $5 / 31$ & $1 / 73.099$ \\
\hline $5 / 25$ & $1 / 89.847$ \\
\hline $5 / 14$ & $1 / 196.078$ \\
\hline $5 / 4$ & $1 / 196.078$ \\
\hline 5 & $1 / 257.069$ \\
\hline $5(2 \mathrm{X}) / 50$ & $1 / 1.942$ \\
\hline $5(2 \mathrm{X}) / 40$ & $1 / 2.439$ \\
\hline $5(2 \mathrm{X}) / 38$ & $1 / 26.103$ \\
\hline $5(2 \mathrm{X}) / 32$ & $1 / 29.922$ \\
\hline $5(2 \mathrm{X}) / 16$ & $1 / 153.374$ \\
\hline $5(2 \mathrm{X})$ & $1 / 254.453$ \\
\hline $20 / 31$ & $1 / 330.033$ \\
\hline $20 / 17$ & $1 / 328.947$ \\
\hline $20 / 10$ & $1 / 350.877$ \\
\hline $20 / 7$ & $1 / 404.858$ \\
\hline $20 / 2$ & $1 / 598.802$ \\
\hline $20(2 \mathrm{X}) / 33$ & $1 / 296.736$ \\
\hline $20(2 \mathrm{X}) / 31$ & $1 / 310.559$ \\
\hline $20(2 \mathrm{X}) / 16$ & $1 / 330.033$ \\
\hline $20(2 \mathrm{X}) / 10$ & $1 / 341.297$ \\
\hline $20(2 \mathrm{X}) / 5$ & $1 / 537.634$ \\
\hline
\end{tabular}

Conforme demonstrado anteriormente [Tabela 15], a Toxina Tetânica Fluida apresentou a $\mathrm{DL}_{50}$ na diluição de $1 / 775.194$ e a Fluida e Adsorvida pelo $\mathrm{Al}(\mathrm{OH})_{3}$, de $1 / 729.927$.

Observa-se que a toxina tetânica tratada pelo mPEG-SPA 5.000 e mPEG-SPA 5.000(2X) apresenta $\mathrm{DL}_{50}$ com diluições no intervalo de 1/257.069 a 1/1.942. Já as amostras conjugadas ao mPEG-SPA 20.000 induzem DL $_{50}$ com diluições entre 1/598.802 e 
1/296.736. As amostras conjugadas ao mPEG-SPA 5.000 e 20.000 apresentaram toxicidade reduzida quando comparadas às amostras de Toxina Fluida e Fluida e Adsorvida pelo $\mathrm{Al}(\mathrm{OH})_{3}$.

Os antígenos formulados com toxina tetânica conjugada ao mPEG-SPA e adsorvida pelo gel de $\mathrm{Al}(\mathrm{OH})_{3}$ e destinados à imunização dos animais, apresentaram diferenças quanto à toxicidade expressa em $\mathrm{DL}_{50}$ [Figuras 20 a 23].

Os antígenos PEGlados e adsorvidos, TxTmPEG-SPA5(2X)/38+gel de $\mathrm{Al}(\mathrm{OH})_{3}$, expressam $\mathrm{DL}_{50}$ na diluição de 1/16.155, enquanto o antígeno TxTmPEG-SPA5/25+ $\mathrm{Al}(\mathrm{OH})_{3}$ teve sua $\mathrm{DL}_{50}$ em 1/89.206. As características físico-químicas e biológica desses antígenos estão demonstradas na Tabela 18.

Tabela 18 - Características das TxT conjugadas ao mPEG-SPA e adsorvidas em gel de $\mathrm{Al}(\mathrm{OH})_{3}$

\begin{tabular}{c|c|c|c}
\hline \multicolumn{1}{c|}{ PRODUTO } & ALUMÍNIO & pH & DL $_{50}$ \\
\hline \hline TxTmPEG-SPA5 $/ 25+$ gel de Al $(\mathrm{OH})_{3}$ & $0,65 \mathrm{mg} / \mathrm{mL}$ & 7,4 & $1 / 89.206$ \\
\hline TxTmPEG-SPA5 $(2 \mathrm{X}) / 38+$ gel de Al $(\mathrm{OH})_{3}$ & $0,63 \mathrm{mg} / \mathrm{mL}$ & 7,3 & $1 / 16.155$ \\
\hline \hline
\end{tabular}

Em comparação à Toxina Fluida e Fluida e Adsorvida em $\mathrm{Al}(\mathrm{OH})_{3}$, esses antígenos apresentaram toxicidade reduzida. Esses dados demonstraram que o tratamento da toxina tetânica pelo mPEG-SPA influencia a perda de sua atividade biológica, fato que pode ter ocorrido devido à neutralização alostérica da proteína em razão da ocupação das aminas pelo polímero; a inibição da toxicidade é importante, pois seus efeitos tóxicos podem ser minimizados.

Esta situação também foi observada com o veneno de Bothrops jararaca tratado pelo mesmo polímero, com diminuição de 50\% na atividade tóxica (STEPHANO, 2005). 


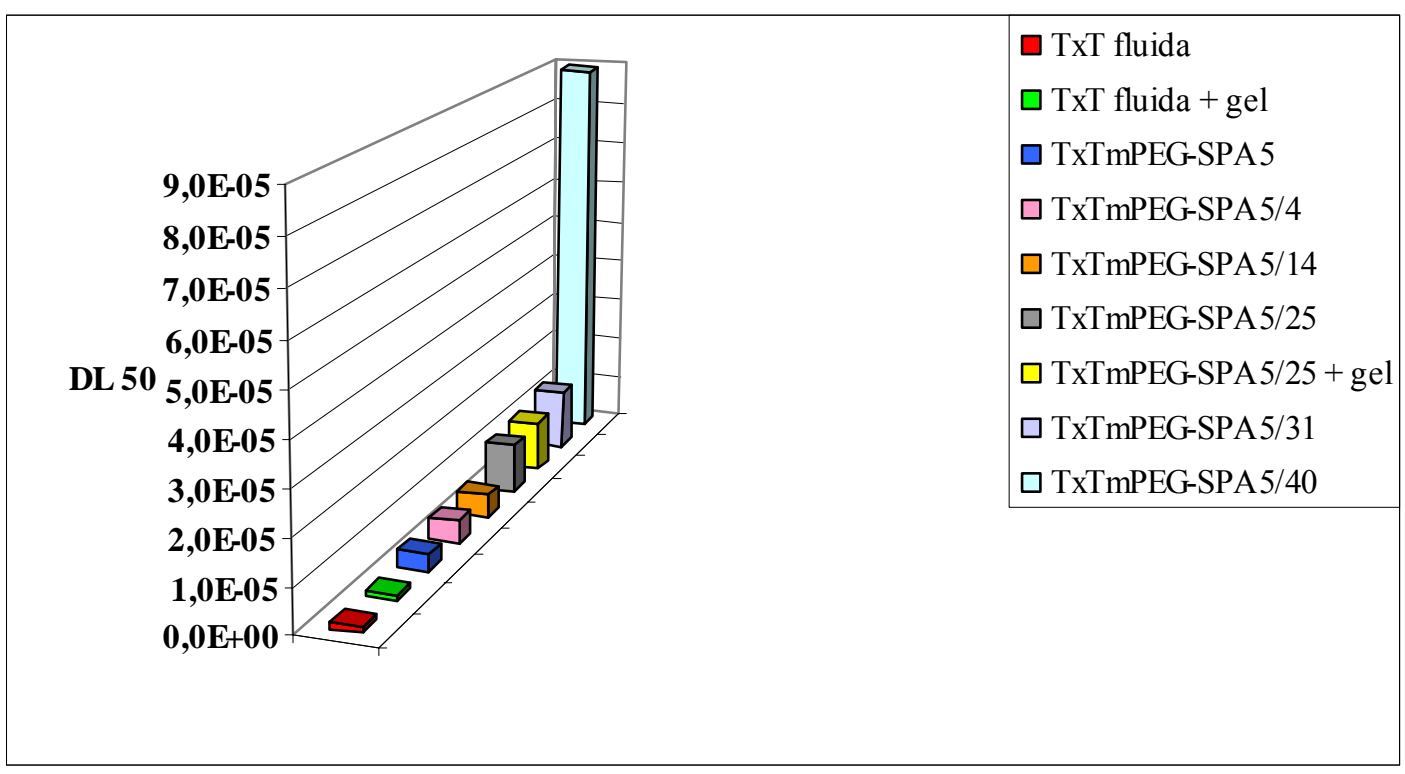

Figura 20 - DL $\mathrm{D}_{50}$ das amostras de TxT conjugadas ao mPEG-SPA 5.000.

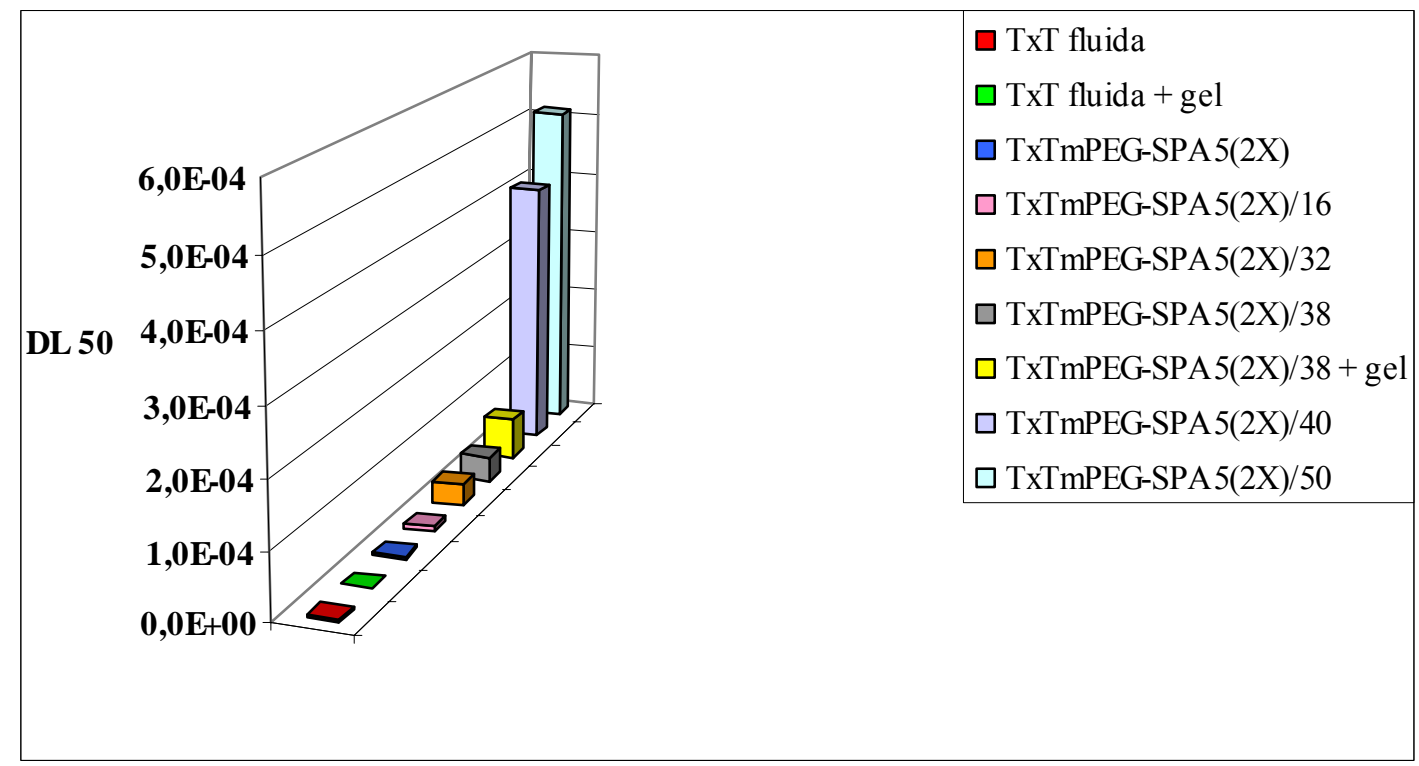

Figura 21 - $\mathrm{DL}_{50}$ das amostras de TxT conjugadas ao mPEG-SPA 5.000(2X). 


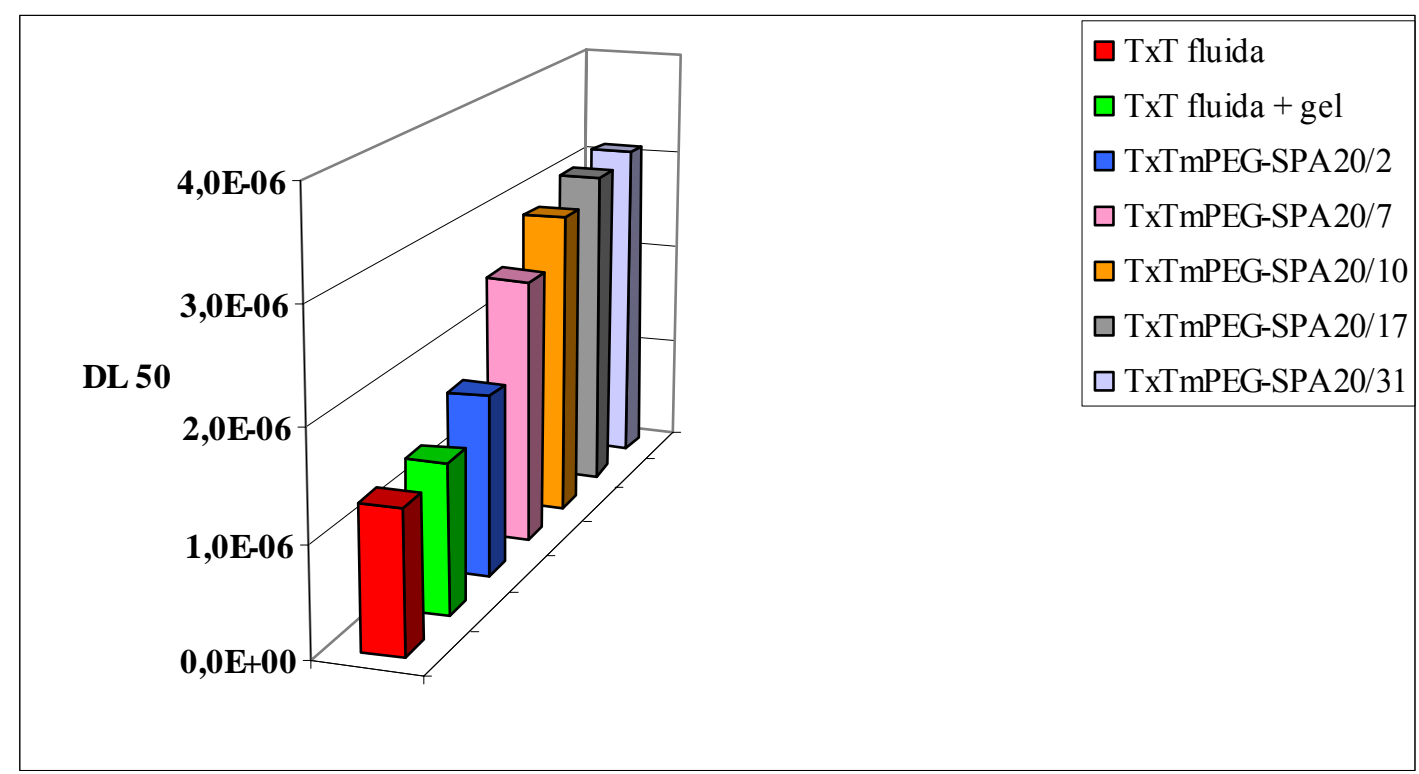

Figura $22-\mathrm{DL}_{50}$ das amostras de TxT conjugadas ao mPEG-SPA 20.000.

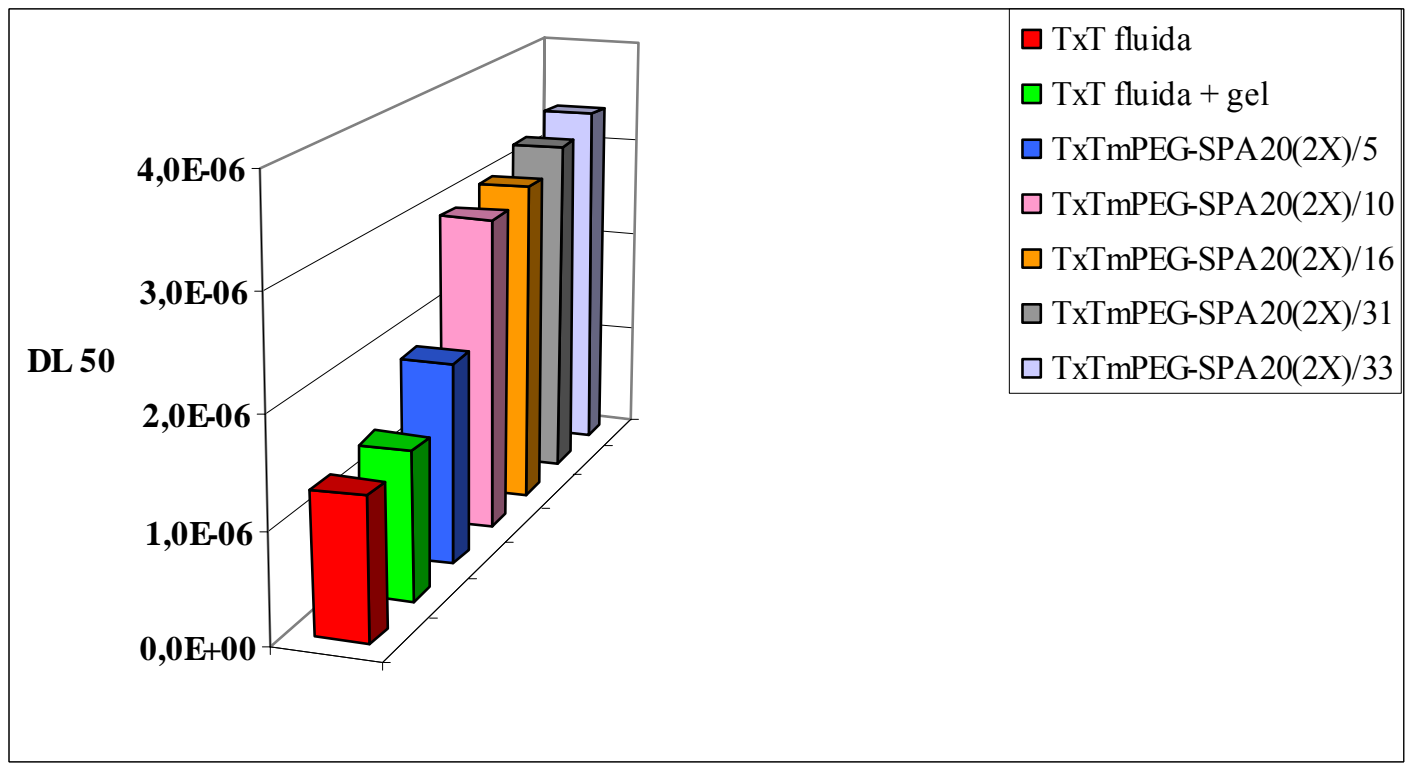

Figura 23 - DL ${ }_{50}$ das amostras de TxT conjugadas ao mPEG-SPA 20.000(2X). 


\subsection{Imunização dos Eqüinos}

\subsubsection{Imunização de Base}

Inicialmente, titulou-se o soro de cada cavalo quanto à concentração de antitoxina tetânica circulante antes de receber dose de Anatoxina Tetânica [Produto Acabado a Granel] correspondente à vacinação contra o tétano. Nesse tempo, considerado tempo zero, os resultados apresentados pelos 30 cavalos estão expressos na Tabela 19, onde se observa que o animal 420 apresentou o título mais elevado de $0,92 \mathrm{UI} / \mathrm{mL}$, sendo o titulo médio de $0,30 \mathrm{UI} / \mathrm{mL}$; os cavalos 288, 435, 442, 443 e 463 foram os únicos que não apresentaram título.

Após 28 dias da vacinação, os títulos alcançaram valores entre 0,12 e $50 \mathrm{UI} / \mathrm{mL}$ e valor médio de $16 \mathrm{UI} / \mathrm{mL}$, desconsiderando-se o animal 288 , que continuou não respondendo [Figura 24].

Tabela 19 - Títulos individuais de eqüinos no tempo zero e após a imunização de base

\begin{tabular}{|c|c|c|}
\hline \multirow{2}{*}{$\mathrm{N}^{0}$. do Cavalo } & TEMPO ZERO & 28 DIAS \\
\hline & \multicolumn{2}{|c|}{$\mathrm{UI} / \mathbf{m L}$} \\
\hline 215 & 0,30 & 25 \\
\hline 223 & 0,27 & 24 \\
\hline 288 & 0,00 & 0 \\
\hline 309 & 0,71 & 20 \\
\hline 326 & 0,46 & 48 \\
\hline 340 & 0,44 & 50 \\
\hline 342 & 0,25 & 4 \\
\hline 391 & 0,85 & 28 \\
\hline 395 & 0,91 & 16 \\
\hline 417 & 0,07 & 9 \\
\hline 420 & 0,92 & 27 \\
\hline 421 & 0,45 & 4 \\
\hline 422 & 0,03 & 12 \\
\hline 423 & 0,46 & 12 \\
\hline 427 & 0,27 & 27 \\
\hline 430 & 0,21 & 11 \\
\hline 433 & 0,13 & 9 \\
\hline 435 & 0,00 & 2 \\
\hline 438 & 0,30 & 13 \\
\hline 440 & 0,41 & 11 \\
\hline 442 & 0,00 & 20 \\
\hline 443 & 0,00 & 5 \\
\hline 451 & 0,01 & 0,12 \\
\hline 454 & 0,01 & 9 \\
\hline 463 & 0,00 & 6 \\
\hline 464 & 0,27 & 18 \\
\hline 465 & 0,05 & 6 \\
\hline 468 & 0,24 & 4 \\
\hline 469 & 0,26 & 13 \\
\hline 470 & 0,60 & 22 \\
\hline $\bar{X}$ & 0,30 & 16 \\
\hline$S$ & 0,28 & 12 \\
\hline
\end{tabular}




\subsubsection{Seleção dos Cavalos}

A partir desses dados selecionou-se um grupo de cavalos para uso exclusivo nos esquemas de imunização com antígeno conjugado ao mPEG-SPA (GUIDOLIN et al., 1992), sendo excluídos os animais 423 e 435 que não apresentaram condições clínicas suficientes. Oitenta e cinco dias após a aplicação da vacina realizou-se a sangria exploradora [item 4.3.2.2]; os títulos de anticorpos dos 28 cavalos são apresentados na Tabela 20, que inclui os títulos alcançados após imunização com 1.000 Lf de Anatoxina Tetânica. O cavalo 288 seguiu sem responder, e os animais 422 e 342 apresentaram 29 e $0,42 \mathrm{UI} / \mathrm{mL}$, maior e menor títulos, respectivamente. $\mathrm{Na}$ seqüência, os cavalos receberam Anatoxina Tetânica adsorvida em $\mathrm{Al}(\mathrm{OH})_{3}$, e os títulos individuais 27 dias após estão representados na mesma Tabela. Foram selecionados os 18 animais que apresentaram títulos mais elevados para prosseguimento do estudo com os antígenos tratados pelo mPEG-SPA. O maior título de $253 \mathrm{UI} / \mathrm{mL}$ foi apresentado pelo cavalo 340, e o menor de $15 \mathrm{UI} / \mathrm{mL}$ pelo 342.

Tabela 20 - Títulos individuais de eqüinos no tempo zero e após a segunda dose vacinal

\begin{tabular}{|c|c|c|}
\hline \multirow{2}{*}{ No $^{0}$ do Cavalo } & TEMPO ZERO & 27 DIAS \\
\hline & \multicolumn{2}{|c|}{$\mathrm{UI} / \mathrm{mL}$} \\
\hline 215 & 8 & 45 \\
\hline 223 & 7 & 66 \\
\hline 288 & 0 & 42 \\
\hline 309 & 7 & 31 \\
\hline 326 & 8 & 110 \\
\hline 340 & 12 & 253 \\
\hline 342 & 0,42 & 15 \\
\hline 391 & 4 & 100 \\
\hline 395 & 1 & 199 \\
\hline 417 & 11 & 35 \\
\hline 420 & 2 & 78 \\
\hline 421 & 2 & 29 \\
\hline 422 & 29 & 31 \\
\hline \multicolumn{3}{|l|}{423} \\
\hline 427 & 3 & 123 \\
\hline 430 & 2 & 80 \\
\hline 433 & 3 & 82 \\
\hline \multicolumn{3}{|l|}{435} \\
\hline 438 & 2 & 19 \\
\hline 440 & 3 & 51 \\
\hline 442 & 11 & 47 \\
\hline 443 & 3 & 43 \\
\hline 451 & 24 & 155 \\
\hline 454 & 6 & 42 \\
\hline 463 & 1 & 29 \\
\hline 464 & 4 & 87 \\
\hline 465 & 4 & 42 \\
\hline 468 & 1 & 23 \\
\hline 469 & 6 & 68 \\
\hline 470 & 6 & 41 \\
\hline $\bar{X}$ & 6 & 70 \\
\hline$s$ & 7 & 55 \\
\hline
\end{tabular}


A Figura 25 apresenta a freqüência dos títulos de antitoxina tetânica circulante obtida no esquema de imunização seletiva. Uma dose de Anatoxina Tetânica adsorvida em gel de $\mathrm{Al}(\mathrm{OH})_{3}$ foi aplicada nos 18 animais, 15 dias após a última sangria exploradora, com o intuito de elevar o nível de antitoxina para iniciar a aplicação dos antígenos tratados pelo mPEG-SPA.

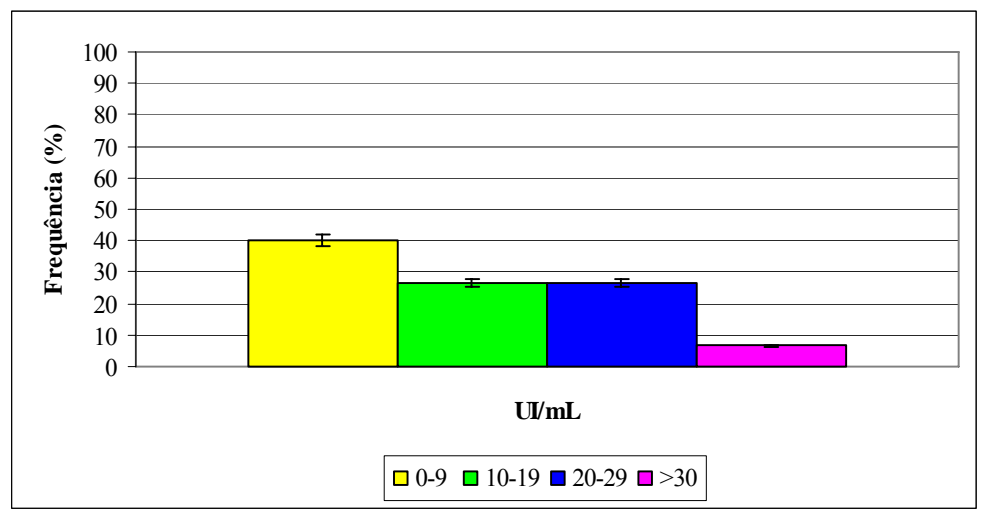

Figura 24 - Distribuição de freqüência dos títulos de anticorpos anti-TxT, 28 dias após reforço vacinal. [Dados constantes da Tabela19].

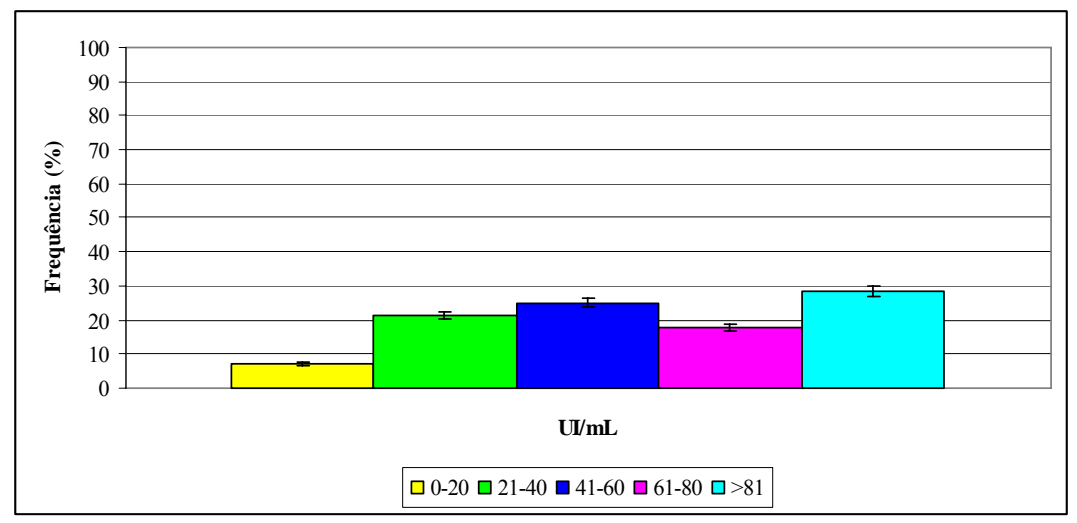

Figura 25 - Distribuição de freqüência dos títulos de anticorpos anti-TxT, 27 dias após a segunda dose. [Dados constantes da Tabela 20]. 


\subsubsection{Formação dos Grupos}

Os 18 cavalos selecionados [item 5.4.2] foram divididos em 3 grupos [Tabela 21].

Tabela 21 - Descrição dos grupos de cavalos destinados à imunização e títulos iniciais de anticorpos anti-TxT

\begin{tabular}{|c|c|c|c|c|c|}
\hline \multicolumn{2}{|c|}{ GRUPO 1} & \multicolumn{2}{|c|}{ GRUPO 2} & \multicolumn{2}{|c|}{ GRUPO 3} \\
\hline CAVALO & $\mathbf{U I} / \mathbf{m L}$ & CAVALO & $\mathrm{UI} / \mathbf{m L}$ & CAVALO & $\mathrm{UI} / \mathbf{m L}$ \\
\hline 223 & 75 & 215 & 44 & 326 & 42 \\
\hline 340 & 114 & 395 & 44 & 391 & 173 \\
\hline 420 & 69 & 427 & 72 & 442 & 41 \\
\hline 430 & 71 & 440 & 84 & 451 & 66 \\
\hline 433 & 54 & 464 & 50 & 454 & 55 \\
\hline 443 & 41 & 469 & 46 & 465 & 46 \\
\hline \multicolumn{2}{|c|}{$\bar{X}=71$} & \multicolumn{2}{|c|}{$\bar{X}=57$} & \multicolumn{2}{|c|}{$\bar{X}=70$} \\
\hline \multicolumn{2}{|c|}{$S=25$} & \multicolumn{2}{|c|}{$S=17$} & \multicolumn{2}{|c|}{$S=51$} \\
\hline
\end{tabular}

A fim de iniciar o estudo de imunização com a toxina modificada, escolheu-se o mPEG-SPA 5.000 por ter apresentado toxicidade reduzida quando comparado ao mPEG-SPA 20.000, já que o principal objetivo era definir antígenos que inibissem a atividade neurotóxica.

Fixou-se o valor de $100 \%$ de PEGlação para o produto TxTmPEG-SPA5/40 que corresponderia à anatoxina tetânica, uma vez que teoricamente a totalidade das aminas estariam com os sítios ocupados pelo polímero e, do mesmo modo que a anatoxina tetânica, a toxina PEGlada não apresentaria toxicidade. Já com $15 \%$ de PEGlação, o produto TxTmPEG-SPA5/4 corresponderia à proteína com atividade tóxica reduzida, uma vez que o valor teórico de $15 \%$ de sítios de aminas estariam ocupados com o mPEG-SPA. Dobrando-se os valores para $200 \%$ e $30 \%$, os produtos correspondentes à anatoxina tetânica seriam o TxTmPEG-SPA5(2X)/50 e o TxTmPEG-SPA5(2X)/16 intermediários à toxina e à anatoxina tetânica. Assim, o esquema de hiperimunização com toxina tetânica conjugada ao mPEG-SPA 5.000 foi iniciado; na Figura 26 são apresentadas as cinéticas de produção de anticorpos nos três grupos de cavalos.

Os cavalos pertencentes ao grupo 1 apresentaram o título médio de $499 \mathrm{UI} / \mathrm{mL}$, considerado o melhor título médio de antitoxina tetânica. Na seqüência, têm-se os grupos 2 e 3 com títulos médios de $392 \mathrm{UI} / \mathrm{mL}$ e $372 \mathrm{UI} / \mathrm{mL}$, respectivamente. Os resultados sugerem que a conjugação TxTmPEG-SPA5/40 e -5/4, onde aproximadamente 40\% e 4\% das lisinas estariam bloqueadas, refletiu na resposta imune. Já no grupo 2, observa-se que o aumento da concentração do polímero (TxTmPEG-SPA5(2X)/50 e (2X)/16) não produziu o mesmo efeito. 


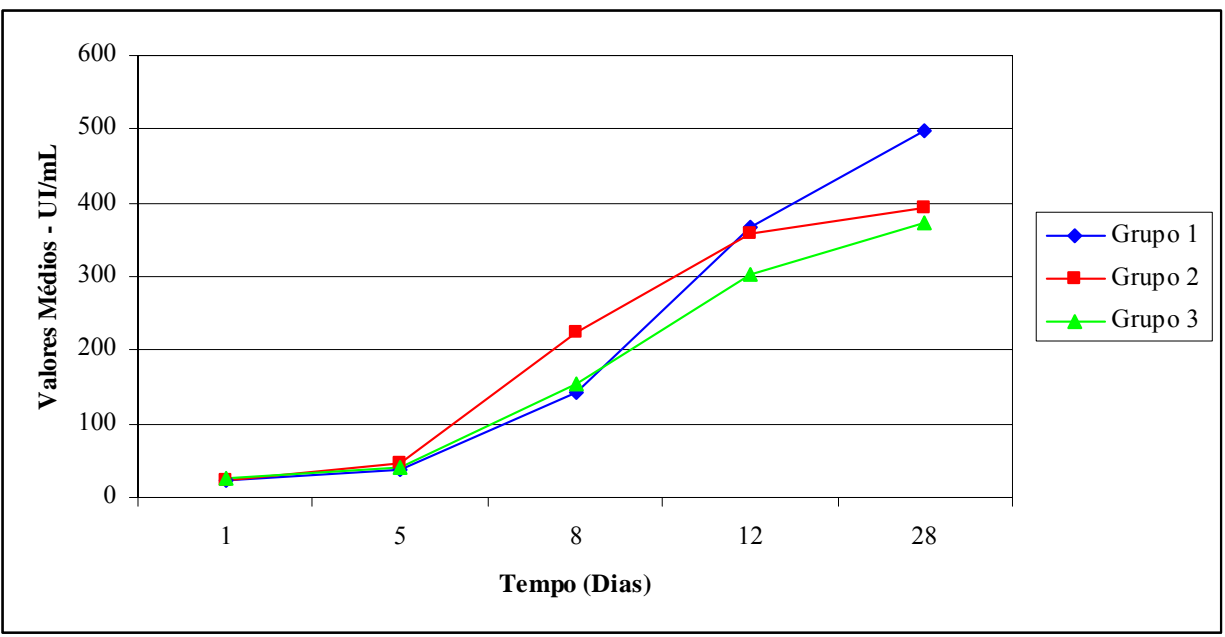

Figura 26 - Cinética de produção de anticorpos anti-TxT em animais imunizados segundo diferentes protocolos.

\subsubsection{Formação dos Subgrupos}

Objetivando avaliar a influência da adsorção pelo gel de $\mathrm{Al}(\mathrm{OH})_{3}$ nos antígenos estudados, os três grupos de cavalos foram subdivididos em seis grupos, sendo que os títulos individuais, as médias e desvios padrão acham-se na Tabela 22 e Figura 27.

Tabela 22 - Perfil dos subgrupos de cavalos destinados à reimunização

\begin{tabular}{|c|c|c|c|c|c|c|c|c|c|c|c|}
\hline \multicolumn{4}{|c|}{ GRUPO 1} & \multicolumn{4}{|c|}{ GRUPO 2} & \multicolumn{4}{|c|}{ GRUPO 3} \\
\hline \multicolumn{2}{|c|}{$1 \mathrm{~A}$} & \multicolumn{2}{|c|}{ 1B } & \multicolumn{2}{|c|}{$2 \mathrm{~A}$} & \multicolumn{2}{|c|}{$2 B$} & \multicolumn{2}{|c|}{ 3A } & \multicolumn{2}{|c|}{ 3B } \\
\hline CAVALO & $\mathrm{UI} / \mathbf{m L}$ & CAVALO & $\mathrm{UI} / \mathbf{m L}$ & CAVALO & $\mathrm{UI} / \mathbf{m L}$ & CAVALO & $\mathrm{UI} / \mathbf{m L}$ & CAVALO & $\mathrm{UI} / \mathbf{m L}$ & CAVALO & $\mathrm{UI} / \mathbf{m L}$ \\
\hline 223 & 2544 & 4330 & 390 & 215 & 4495 & 427 & 466 & 391 & 620 & 326 & 236 \\
\hline 340 & 1213 & 433 & 381 & 395 & 348 & 440 & 271 & 442 & 453 & 451 & 407 \\
\hline 420 & 180 & 443 & 286 & 469 & 466 & 464 & 329 & 465 & 183 & 454 & 333 \\
\hline \multicolumn{2}{|c|}{$X=645$} & \multicolumn{2}{|c|}{$\bar{X}=352$} & \multicolumn{2}{|c|}{$\bar{X}=436$} & \multicolumn{2}{|c|}{$\bar{X}=355$} & \multicolumn{2}{|c|}{$\bar{X}=419$} & \multicolumn{2}{|c|}{$\bar{X}=325$} \\
\hline \multicolumn{2}{|c|}{$s=524$} & \multicolumn{2}{|c|}{$s=58$} & \multicolumn{2}{|c|}{$s=78$} & \multicolumn{2}{|c|}{$s=100$} & \multicolumn{2}{|c|}{$s=220$} & \multicolumn{2}{|c|}{$s=86$} \\
\hline
\end{tabular}

Os três subgrupos com as maiores médias iniciais (identificados pela letra A seguida ao número) foram destinados aos esquemas de imunização, sem o gel de $\mathrm{Al}(\mathrm{OH})_{3}$. Com o esquema de primeira reimunização deu-se início ao estudo comparativo entre as toxinas conjugadas ao mPEG-SPA 5.000 adsorvidas ou não ao gel de $\mathrm{Al}(\mathrm{OH})_{3}$, bem como pela Toxina Tetânica Fluida ou adsorvida ao $\mathrm{Al}(\mathrm{OH})_{3}$. 


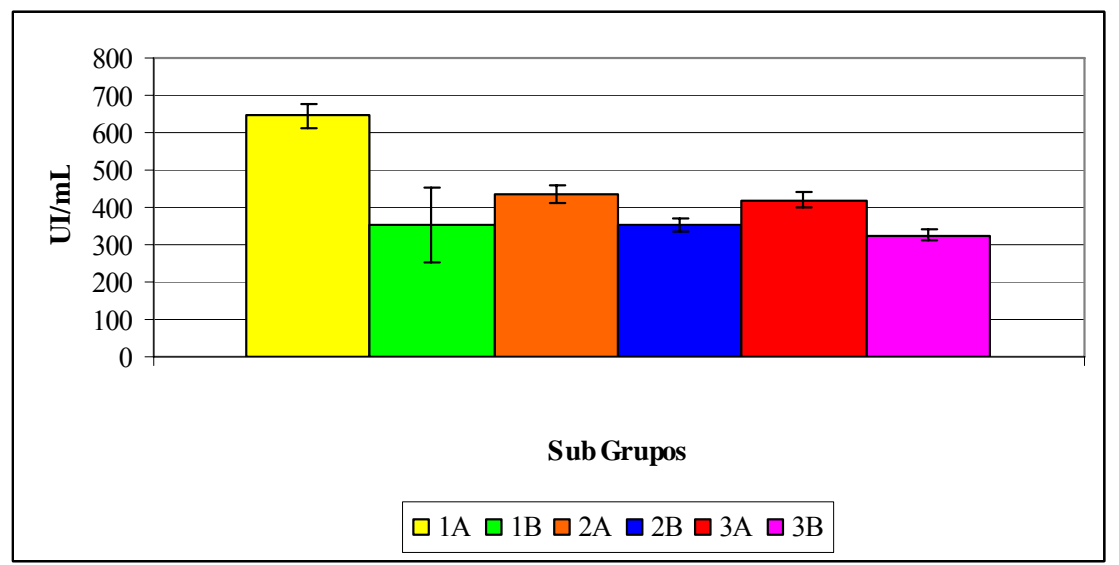

Figura 27 - Títulos médios de anticorpos anti-TxT. [Dados da Tabela 23].

Assim, os cavalos foram imunizados com as seguintes preparações:

a) grupo $1 \mathrm{~A}$ - TxTmPEG-SPA5/25;

b) grupo $1 \mathrm{~B}-\mathrm{TxTmPEG}-\mathrm{SPA} 5 / 25+$ gel de $\mathrm{Al}(\mathrm{OH})_{3}$;

c) grupo $2 \mathrm{~A}$ - TxTmPEG-SPA5(2X)/38;

d) grupo $2 \mathrm{~B}-\mathrm{TxTmPEG}-\mathrm{SPA} 5(2 \mathrm{X}) / 38+$ gel de $\mathrm{Al}(\mathrm{OH})_{3}$;

e) grupo $3 \mathrm{~A}$ - toxina tetânica fluida;

f) grupo 3B - toxina tetânica fluida + gel de $\mathrm{Al}(\mathrm{OH})_{3}$.

Os resultados individuais, as médias e desvios padrão de anticorpos de cada subgrupo estão expressos na Tabela 23 e Figura 28. 
Tabela 23 - Títulos de anticorpos anti-TxT obtidos nos esquemas de primeira reimunização

\begin{tabular}{|c|c|c|c|c|c|c|}
\hline \multirow{2}{*}{ GRUPO } & \multirow{2}{*}{ SUBGRUPO } & \multirow{2}{*}{$\begin{array}{c}\text { IDENTIFICAÇÃO } \\
\text { DO CAVALO }\end{array}$} & \multicolumn{4}{|c|}{ TEMPO (DIAS) } \\
\hline & & & 1 & 4 & 10 & 26 \\
\hline \multirow{10}{*}{1} & \multirow{5}{*}{$1 \mathrm{~A}$} & 223 & 119 & 212 & 397 & 472 \\
\hline & & 340 & 279 & 381 & 597 & 695 \\
\hline & & 420 & 49 & 2 & 5 & 16 \\
\hline & & $\bar{X}$ & 149 & 198 & 333 & 583 \\
\hline & & $s$ & 118 & 190 & 301 & 346 \\
\hline & \multirow{5}{*}{ 1B } & 430 & 35 & 161 & 208 & 271 \\
\hline & & 433 & 116 & 229 & 471 & 690 \\
\hline & & 443 & 219 & 330 & 447 & 499 \\
\hline & & $\bar{X}$ & 123 & 240 & 375 & 487 \\
\hline & & $s$ & 92 & 85 & 146 & 210 \\
\hline \multirow{10}{*}{2} & \multirow{5}{*}{$2 \mathrm{~A}$} & 215 & 145 & 145 & 222 & 363 \\
\hline & & 395 & 230 & 323 & 317 & 587 \\
\hline & & 469 & 292 & 422 & 616 & 1001 \\
\hline & & $\bar{X}$ & 222 & 297 & 385 & 650 \\
\hline & & $s$ & 74 & 140 & 206 & 324 \\
\hline & \multirow{5}{*}{$2 \mathrm{~B}$} & 427 & 125 & 217 & 2598 & 719 \\
\hline & & 440 & 52 & 122 & 190 & 274 \\
\hline & & 464 & 95 & 279 & 318 & 336 \\
\hline & & $\bar{X}$ & 91 & 206 & 369 & 443 \\
\hline & & $s$ & 37 & 79 & 209 & 241 \\
\hline \multirow{10}{*}{3} & \multirow{5}{*}{$3 \mathrm{~A}$} & 391 & 264 & 4339 & 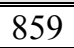 & 9991 \\
\hline & & 442 & 86 & 170 & 277 & 399 \\
\hline & & 465 & 39 & 73 & 124 & 142 \\
\hline & & $\bar{X}$ & 129 & 227 & 420 & 511 \\
\hline & & $s$ & 119 & 190 & 388 & 435 \\
\hline & \multirow{5}{*}{$3 \mathrm{~B}$} & 326 & 129 & 174 & 209 & 234 \\
\hline & & 451 & 155 & 215 & 348 & 440 \\
\hline & & 454 & 162 & 269 & 319 & 362 \\
\hline & & $\bar{X}$ & 149 & 219 & 292 & 345 \\
\hline & & $s$ & 17 & 48 & 74 & 104 \\
\hline
\end{tabular}

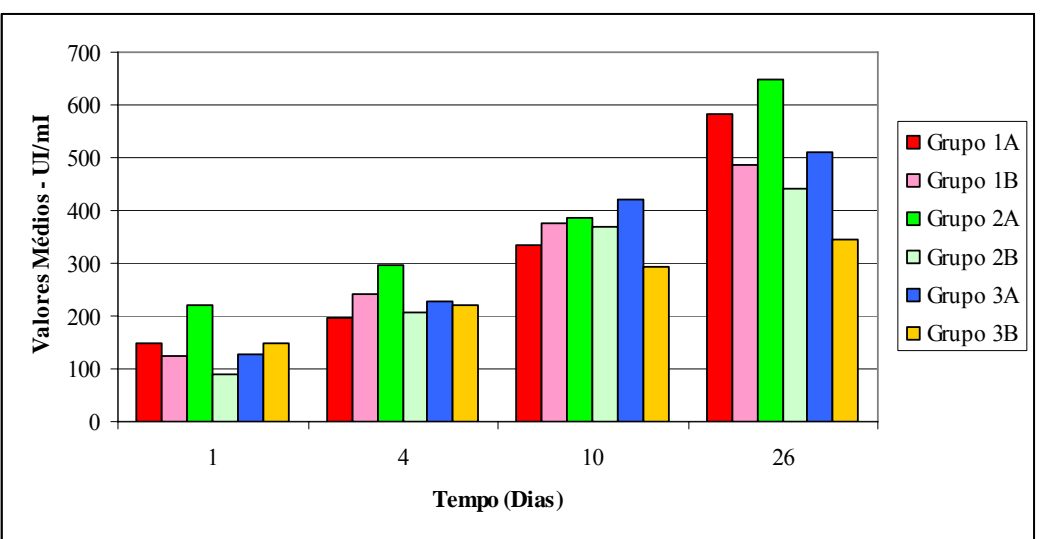

Figura 28 - Valores médios de anticorpos anti-TxT obtidos ao término da primeira reimunização. [Dados da Tabela 23]. 
Um dos animais [420] foi excluído por não apresentar bom estado clínico e seu título não entrou no cálculo de média do grupo que passou a contar com dois cavalos apenas. Por outro lado, os animais 469 e 391, que receberam os antígenos solúveis, apresentaram os maiores títulos individuais. Os resultados dos esquemas de primeira reimunização mostram que o TxTmPEG-SPA5(2X)/38 foi a preparação responsável pelo título médio de $650 \mathrm{UI} / \mathrm{mL}$, o melhor entre os seis subgrupos, e o TxTmPEG-SPA5/25, que também não era adsorvido, o segundo melhor. Esses resultados demonstram que o aumento da concentração do polímero elevou a resposta imune ao antígeno tetânico. Com a Toxina Tetânica Fluida e adsorvida pelo $\mathrm{Al}(\mathrm{OH})_{3}$ a média foi de $345 \mathrm{UI} / \mathrm{mL}$, a menor dentre os subgrupos. Em todos os subgrupos, a adição do gel ocasionou a queda da resposta imune ao antígeno tetânico e, com o aumento da concentração do polímero associado à adsorção pelo $\mathrm{Al}(\mathrm{OH})_{3}$ - comparação entre os subgrupos 1B e 2B - a queda é ainda maior.

O segundo e último esquema de imunização teve início 48 dias após a última sangria exploradora. Foram utilizadas as mesmas preparações do esquema anterior em quatro doses. Os resultados individuais e as médias constam na Tabela 24 e na Figura 29.

Os grupos $1 \mathrm{~A}$ e $3 \mathrm{~A}$ apresentaram valores médios semelhantes, além de serem os maiores dentre os subgrupos, evidenciando que a presença do polímero não influenciou na resposta contra o antígeno tetânico. Com exceção do subgrupo $2 \mathrm{~B}$, o uso do gel de $\mathrm{Al}(\mathrm{OH})_{3}$ não favoreceu a resposta ao antígeno tetânico, e as médias entre os subgrupos 1A e 1B e entre 3A e 3B são 1,7 e 1,5 vezes superiores quando o antígeno não foi adsorvido ao $\mathrm{Al}(\mathrm{OH})_{3}$, respectivamente. Ao término da segunda reimunização, verifica-se que no subgrupo 1A a média dos títulos alcançada com o emprego do TxTmPEG-SPA5/25 aumentou 1,1 vez [Tabela 24] em relação ao esquema de primeira reimunização do mesmo subgrupo expresso na Tabela 23. 
Tabela 24 - Títulos de anticorpos anti-TxT obtidos no esquema de segunda reimunização

\begin{tabular}{|c|c|c|c|c|c|c|}
\hline \multirow{2}{*}{ GRUPO } & \multirow{2}{*}{ SUBGRUPO } & \multirow{2}{*}{$\begin{array}{c}\text { IDENTIFICAÇÃO } \\
\text { DO CAVALO } \\
\end{array}$} & \multicolumn{4}{|c|}{ TEMPO (DIAS) } \\
\hline & & & 1 & 6 & 16 & 25 \\
\hline \multirow{9}{*}{1} & \multirow{4}{*}{$1 \mathrm{~A}$} & 223 & 173 & 305 & 568 & 627 \\
\hline & & 340 & 321 & 380 & 670 & 674 \\
\hline & & $X$ & 247 & 342 & 619 & 651 \\
\hline & & $\mathbf{s}$ & 104 & 53 & 72 & 33 \\
\hline & \multirow{5}{*}{ 1B } & 430 & 167 & 187 & 264 & 285 \\
\hline & & 433 & 140 & 260 & 347 & 415 \\
\hline & & 443 & 218 & 269 & 356 & 438 \\
\hline & & $X$ & 175 & 239 & 322 & 379 \\
\hline & & $\mathbf{s}$ & 40 & 45 & 51 & 82 \\
\hline \multirow{10}{*}{2} & \multirow{5}{*}{$2 \mathrm{~A}$} & 215 & 202 & 253 & 269 & 300 \\
\hline & & 395 & 184 & 233 & 316 & 354 \\
\hline & & 469 & 356 & 413 & 473 & 531 \\
\hline & & $\bar{X}$ & 247 & 299 & 353 & 395 \\
\hline & & $\mathbf{s}$ & 94 & 99 & 107 & 121 \\
\hline & \multirow{5}{*}{ 2B } & 427 & 410 & 451 & 538 & 699 \\
\hline & & 440 & 73 & 188 & 220 & 358 \\
\hline & & 464 & 104 & 272 & 392 & 551 \\
\hline & & $\bar{X}$ & 196 & 304 & 383 & 536 \\
\hline & & $\mathbf{s}$ & 186 & 134 & 159 & 171 \\
\hline \multirow{10}{*}{3} & \multirow{5}{*}{$3 \mathrm{~A}$} & 391 & 373 & 760 & 1167 & 1279 \\
\hline & & 442 & 195 & 249 & 479 & 525 \\
\hline & & 465 & 61 & 95 & 125 & 148 \\
\hline & & $X$ & 210 & 368 & 590 & 651 \\
\hline & & $\mathbf{s}$ & 157 & 348 & 530 & 576 \\
\hline & \multirow{5}{*}{ 3B } & 326 & 171 & 139 & 235 & 327 \\
\hline & & 451 & 213 & 350 & 420 & 635 \\
\hline & & 454 & 164 & 293 & 319 & 341 \\
\hline & & $X$ & 182 & 261 & 325 & 434 \\
\hline & & $\mathbf{s}$ & 27 & 109 & 93 & 174 \\
\hline
\end{tabular}

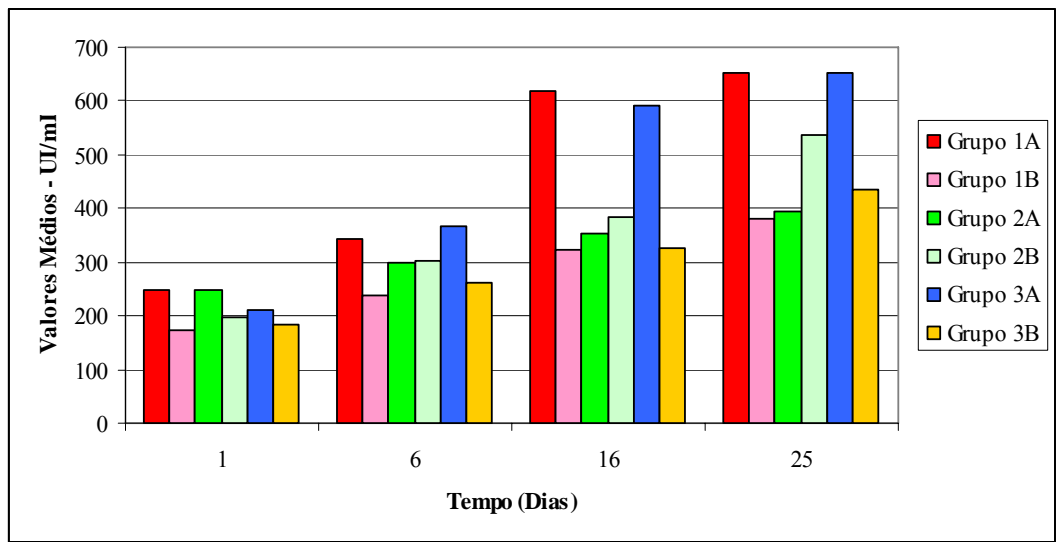

Figura 29 - Valores médios de anticorpos anti-TxT obtidos ao término da segunda reimunização. [Dados da Tabela 24]. 
A adição do $\mathrm{Al}(\mathrm{OH})_{3}$ ao TxTmPEG-SPA5/25 (subgrupo 1B) acarretou uma queda maior do título de antitoxina tetânica (1,7 vezes) comparativamente aos títulos do mesmo grupo (1,2 vezes) descritos na Tabela 23. Quanto ao grupo 2, a segunda reimunização associada ao aumento da concentração do polímero (sem gel de $\mathrm{Al}(\mathrm{OH})_{3}$ - subgrupo 2A) provocou redução de 1,6 vezes na resposta ao antígeno em relação à média do mesmo subgrupo (Tabela 23). Já a adição do gel de $\mathrm{Al}(\mathrm{OH})_{3}$ na segunda reimunização do subgrupo 2B induziu o aumento dos títulos [Tabelas 23 e 24]; observa-se, ainda, que no grupo 3 tanto a primeira quanto a segunda reimunização provocaram aumento da resposta com o emprego da Toxina Tetânica Fluida adsorvida ou não pelo gel de $\mathrm{Al}(\mathrm{OH})_{3}$.

Nos esquemas rotineiros de hiperimunização realizados no Instituto Butantan os cavalos que atingem títulos iguais ou maiores que $400 \mathrm{UI} / \mathrm{mL}$ são selecionados para a sangria destinada à produção do soro antitetânico; pode-se concluir que sob esse aspecto $58 \%$ dos animais empregados nesse estudo seriam potencialmente soroprodutores; o subgrupo 1A representado por apenas dois cavalos, foi o único no qual todos os animais atenderam a esse critério.

Saliente-se que nenhuma das preparações resultaram tóxicas, com ausência total de reações local ou sistêmica.

Confome referido no item 4 [Materiais e Métodos], o total do plasma obtido com as sangrias de todos os cavalos foi encaminhado para a Seção de Processamento de Plasmas Hiperimunes do Serviço de Imunologia da Divisão de Desenvolvimento Tecnológico e Produção do Instituto Butantan sendo, destinado à produção de soro antitetânico para uso terapêutico humano.

Ao término dos esquemas de imunização dos eqüinos, amostras dos soros dos cavalos foram submetidas aos ensaios de imunodifusão, eletroforese e immunoblotting com o objetivo de avaliar possíveis diferenças qualitativas de reconhecimento. 


\subsubsection{Imunodifusão}

A fim de verificar o reconhecimento pelos antisoros dos cavalos imunizados com toxina tetânica conjugada ao mPEG-SPA, fluida e adsorvida pelo gel de $\mathrm{Al}(\mathrm{OH})_{3}$, realizou-se o ensaio de imunodifusão. Não se trata de um teste utilizado na rotina de produção, mas por ser prático, rápido e simples, foi empregado para avaliar a resposta individual dos cavalos. $\mathrm{O}$ controle negativo usado foi o antisoro do cavalo 420, que havia sido separado do grupo de imunização por não apresentar resposta satisfatória ao antígeno tetânico. Pela Figura 30(a), o antisoro desse animal foi o único que não formou linha de precipitação. Verifica-se que a melhor reação de precipitação (resposta até 1/32) ocorreu com o antisoro do cavalo 391, Figura 30(e), confirmando ser esse o que melhor respondeu ao esquema de imunização, corroborando o resultado no ensaio ToBI Teste que detectou $1.279 \mathrm{UI} / \mathrm{mL}$. O menor valor detectado no ToBI Teste foi de $148 \mathrm{UI} / \mathrm{mL}$ para o antisoro do cavalo 465, confirmado na imunodifusão [Figura 30(e)], único antisoro cuja precipitação ocorreu na diluição de 1/2. Valores entre 627 e $699 \mathrm{UI} / \mathrm{mL}$ reagiram até a diluição de 1/16; entre 415 e $551 \mathrm{UI} / \mathrm{mL}$ reagiram até $1 / 8$ (exceto o cavalo 440 com $358 \mathrm{UI} / \mathrm{mL}$ ), e entre 285 e $354 \mathrm{UI} / \mathrm{mL}$ até $1 / 4$ (exceto o cavalo 469, com $531 \mathrm{UI} / \mathrm{mL}$ ).

A comparação entre as Figuras 30(a) e 30(b), bem como entre a 30(c) e 30(d), revela que os antisoros obtidos frente aos antígenos conjugados ao mPEG-SPA e adsorvidos pelo $\mathrm{Al}(\mathrm{OH})_{3}$ apresentaram linhas de precipitação mais intensas, fato que não foi evidenciado para os antígenos não conjugados ao mPEG-SPA, conforme as Figuras 30(e) e 30(f).

Os resultados das imunodifusões indicam a possibilidade de separar os cavalos em três grupos de respostas que podem ser descritas como fraca, intermediária e de alta intensidade. 


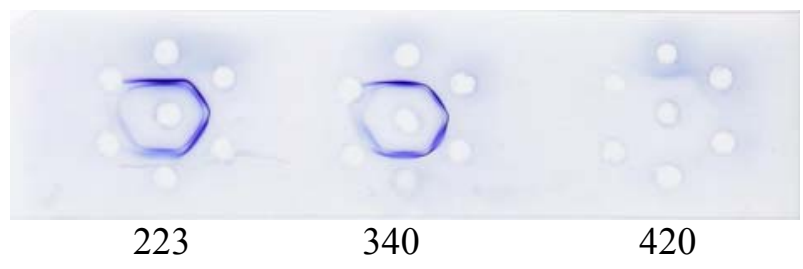

(a) Grupo 1A - Toxina Tetânica mPEG-SPA 5.000

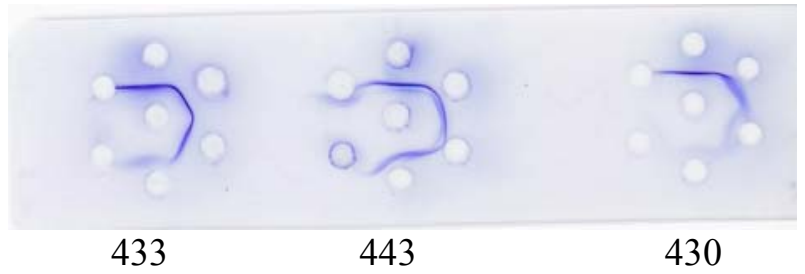

(b) Grupo 1B - Toxina Tetânica mPEG-SPA $5.000+\mathrm{Al}(\mathrm{OH})_{3}$

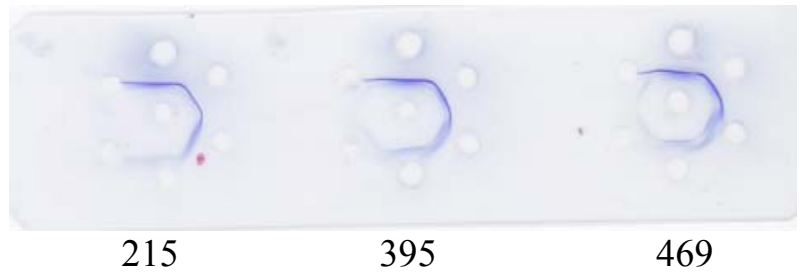

(c) Grupo 2A - Toxina Tetânica mPEG-SPA 5.000(2X)

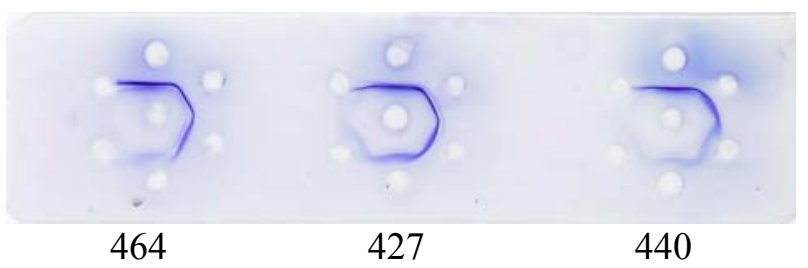

(d) Grupo 2B - Toxina Tetânica mPEG-SPA 5.000(2X) + Al(OH)

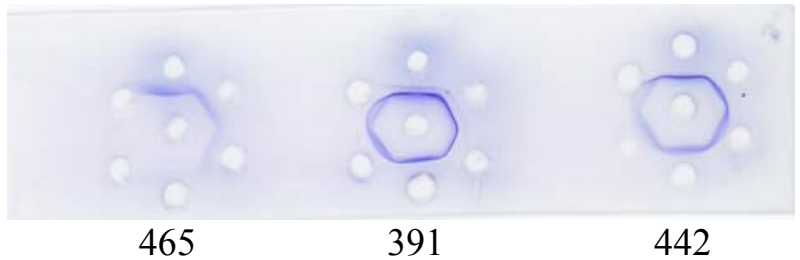

(e) Grupo 3A - Toxina Tetânica Fluída

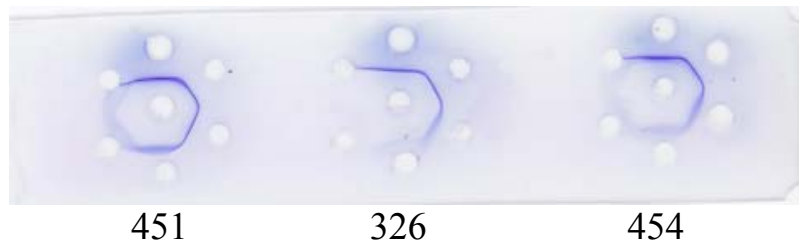

(f) Grupo 3B - Toxina Tetânica Fluída $+\mathrm{Al}(\mathrm{OH})_{3}$

$$
{ }_{4}^{3}{ }^{3}{ }^{0}{ }^{0} 0^{7}
$$

Figura 30 - Imunodifusão. ${ }^{{ }^{\circ}}{ }^{\circ}$ Orifício 1 (central) - Toxina Tetânica Purificada $(1 \mathrm{mg} / \mathrm{mL})$. Orifício 7 - Amostra diluída 1:2. Orifício 6 - Amostra diluída 1:4. Orifício 5 - Amostra diluída 1:8. Orifício 4 - Amostra diluída 1:16. Orifício 3 - Amostra diluída 1:32. Orifício 2 - Amostra pura. 


\subsubsection{Identificação de Imunoglobulina Através de Eletroforese em Gel de Poliacrilamida (SDS-PAGE)}

Os antisoros produzidos em cavalos contra várias proteínas, dependendo de fases da imunização, apresentam, além dos anticorpos $\operatorname{IgG}$, o isótipo $\operatorname{IgG}(\mathrm{T})$. Eqüínos normais possuem essa imunoglobulina em baixo nível que se eleva durante imunizações, tais como frente às toxinas tetânica e diftérica; é esse isótipo o responsável pelo precipitado que aparece quando da floculação de Ramon para titulação in vitro de antitoxinas (FERRI et al., 1979). A nomenclatura das imunoglobulinas do cavalo, e em particular das subclasses de IgG, foi baseada em estudo recente. De acordo com as diferenças antigênicas e as propriedades eletroforéticas e sorológicas definiram-se as seguintes subclasses: IgG, IgGa, IgGb, IgGc, IgG(T) e IgG(B), sendo a última a imunoglobulina agregada (AI) (WAGNER, 2006).

A fim de determinar as IgG no soro dos cavalos imunizados, realizou-se o ensaio de eletroforese (SDS-PAGE), sendo que para todos os grupos estudados o perfil eletroforético foi idêntico, assim o gel apresentado na Figura 31 foi selecionado como representativo. Os antisoros apresentaram uma banda próxima a $53 \mathrm{kDa}$ e bandas difusas entre $116 \mathrm{kDa}$ e $220 \mathrm{kDa}$ que podem estar relacionadas com imunoglobulina IgG, cuja massa molecular é de $160 \mathrm{kDa}$ (MOTA, 1989); precipitados com massa molecular acima de $220 \mathrm{kDa}$ e entre $53 \mathrm{kDa}$ e $76 \mathrm{kDa}$ também foram observados em todos os géis. Conforme esperado, não foi possível visualizar diferenças que poderiam estar relacionadas com o tipo de preparação empregada nas imunizações. Pelo fato de todas as amostras terem sido congeladas durante esse estudo, as bandas de $53 \mathrm{kDa}$ e aquelas entre $53 \mathrm{kDa}$ e $76 \mathrm{kDa}$ poderiam estar relacionadas à fragmentação das IgG (CONNELL e PAINTER,1966). Objetivando certificar essa hipótese, amostras não congeladas de antisoros de dois cavalos pertencentes ao grupo rotineiro de imunização (animais 299 e 301), mantidas por 24 horas a $23{ }^{\circ} \mathrm{C} \pm 2{ }^{\circ} \mathrm{C}$, e uma alíquota congelada a $-20^{\circ} \mathrm{C}$ durante esse mesmo tempo, foram analisadas [Figura 32]. 


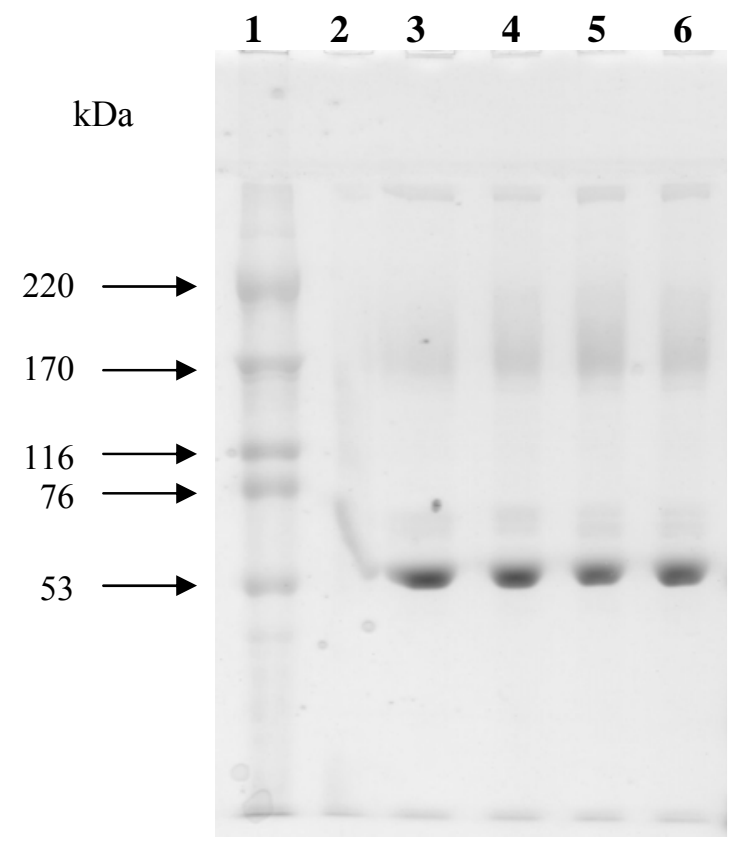

Figura 31 - Eletroforese em Gel de Acrilamida (SDS-PAGE) em concentração de 7,5\% de acrilamida, coloração com Coomassie Blue 250 R. Amostras de soros de cavalos não tratadas com 2-mercaptoetanol aplicadas com uma concentração de proteínas de $0,7 \mathrm{mg} / \mathrm{mL}$. Linha $1-$ Padrão de massa molecular High Molecular Weight; linha 2 - cavalo 223; linha 3 cavalo 340; linha 4 - cavalo 430; linha 5 - cavalo 433; linha 6 - cavalo 443.

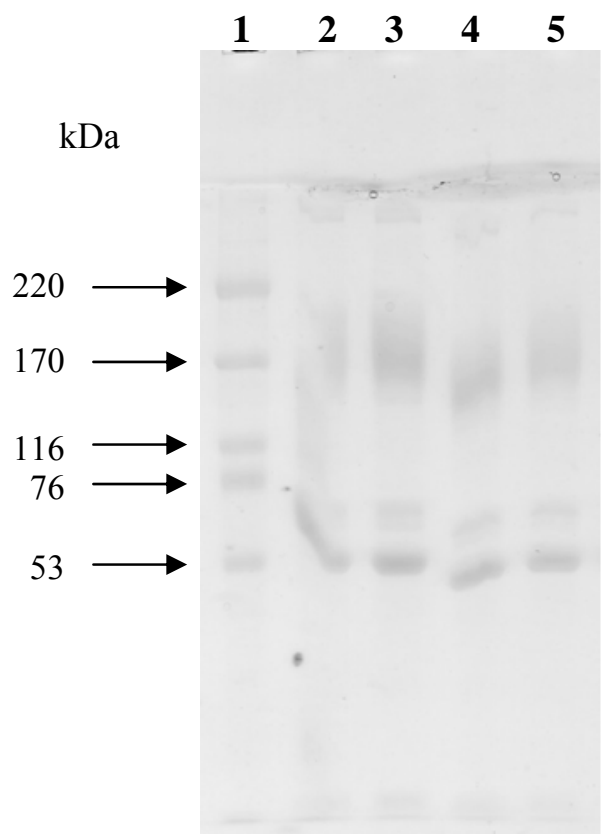

Figura 32 - Eletroforese em Gel de Acrilamida (SDS-PAGE) em concentração de 7,5\% de acrilamida, coloração com Coomassie Blue 250 R. Amostras de soros de cavalos não tratadas com 2-mercaptoetanol aplicadas com uma concentração de proteínas de $0,7 \mathrm{mg} / \mathrm{mL}$. Linha 1 Padrão de massa molecular High Molecular Weight; linha 2 - cavalo 299 (soro não congelado); linha 3 - cavalo 299 (soro congelado); linha 4 - cavalo 301 (soro não congelado); linha 5 - cavalo 301 (soro congelado). 
As bandas de $53 \mathrm{kDa}$ e aquelas entre 53 e $76 \mathrm{kDa}$ estão visíveis em todas amostras e, assim, não há eventual fragmentação da $\operatorname{IgG}$ durante o período de estocagem. Logo as bandas entre 53 e $76 \mathrm{kDa}$ podem estar relacionadas à presença de albumina sérica cujo peso molecular está na faixa de 66.000 e 69.000 Da (JONES e LANDON, 2002).

\subsubsection{Immunoblotting}

Pools referentes às amostras dos soros de todos os subgrupos foram submetidos ao ensaio immunoblotting. Esse teste possibilita melhor caracterizar a resposta específica e determinar se a toxina tetânica não conjugada com mPEG-SPA ou adsorvida em $\mathrm{Al}(\mathrm{OH})_{3}$ seria reconhecida pelos soros dos animais imunizados com a toxina conjugada ao mPEG-SPA, com a Toxina Fluida, ou Fluida e Adsorvida ao $\mathrm{Al}(\mathrm{OH})_{3}$. Como controle utilizou-se um soro negativo. Os resultados podem ser observados nas Figuras 33 a 36:

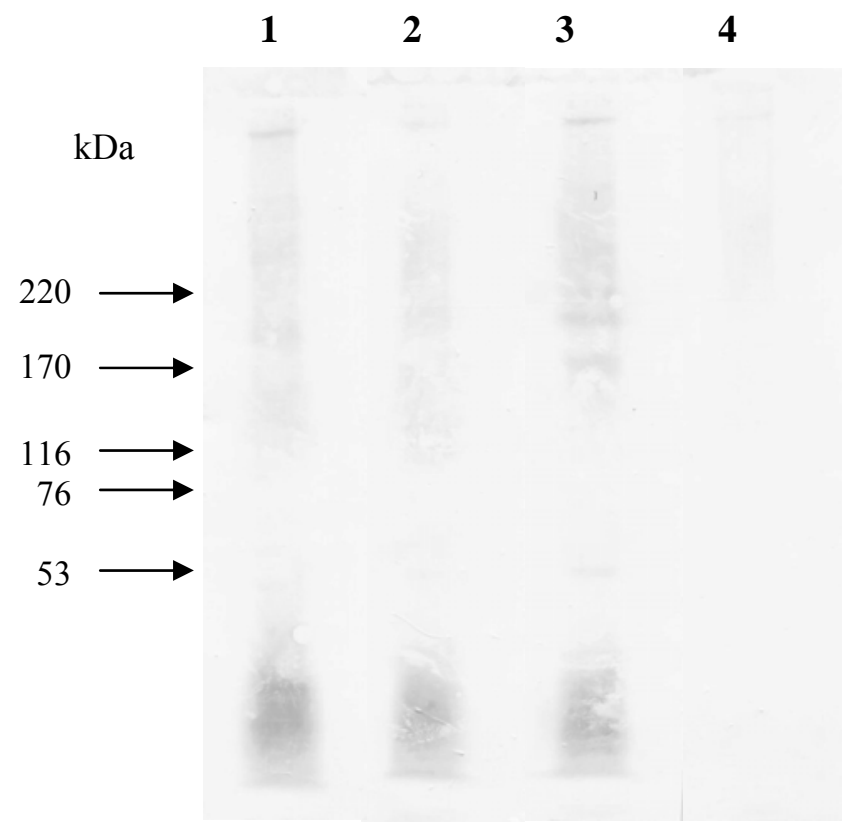

Figura 33 - Membrana de Immunoblotting. Gel de acrilamida em concentração de 7,5\% de acrilamida, coloração com Coomassie Blue $250 \mathrm{R}$. Toxina Tetânica não tratada com 2mercaptoetanol. Linha 1 - pool das amostras de soro dos cavalos do Grupo 1A; linha 2 pool das amostras de soro dos cavalos do Grupo 2A; linha 3 - pool das amostras de soro dos cavalos do Grupo 3A; linha 4 - soro normal de cavalo. 


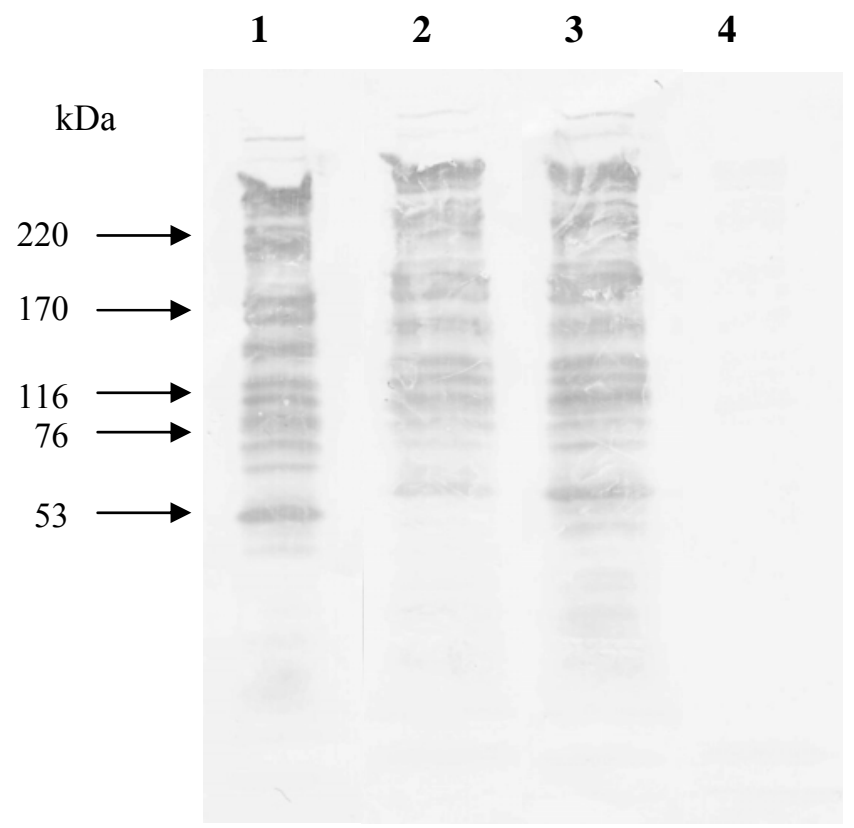

Figura 34 - Membrana de Immunoblotting. Gel de acrilamida em concentração de 7,5\% de acrilamida, coloração com Coomassie Blue 250 R. Toxina Tetânica tratada com 2-mercaptoetanol. Linha 1 - pool das amostras de soro dos cavalos do Grupo 1A; linha 2 - pool das amostras de soro dos cavalos do Grupo 2A; linha 3 - pool das amostras de soro dos cavalos do Grupo 3A; linha 4 - soro normal de cavalo.

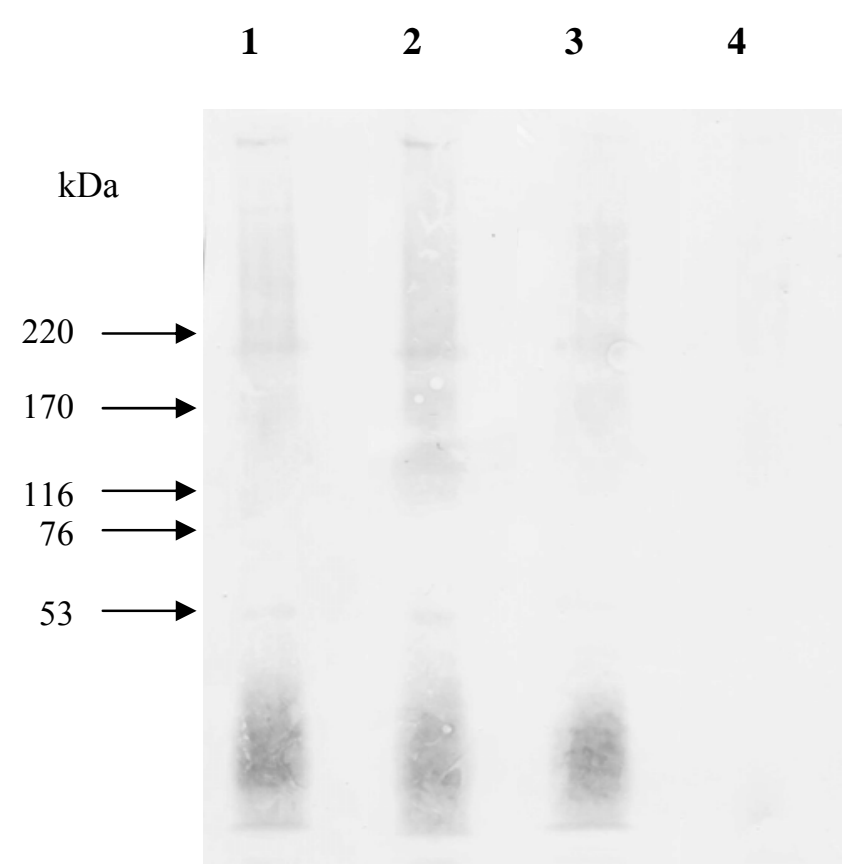

Figura 35 - Membrana de Immunoblotting. Gel de acrilamida em concentração de 7,5\% de acrilamida, coloração com Coomassie Blue $250 \mathrm{R}$. Toxina Tetânica não tratada com 2mercaptoetanol. Linha 1 - pool das amostras de soro dos cavalos do Grupo 1B; linha 2 pool das amostras de soro dos cavalos do Grupo 2B; linha 3 - pool das amostras de soro dos cavalos do Grupo 3B; linha 4 - soro normal de cavalo. 


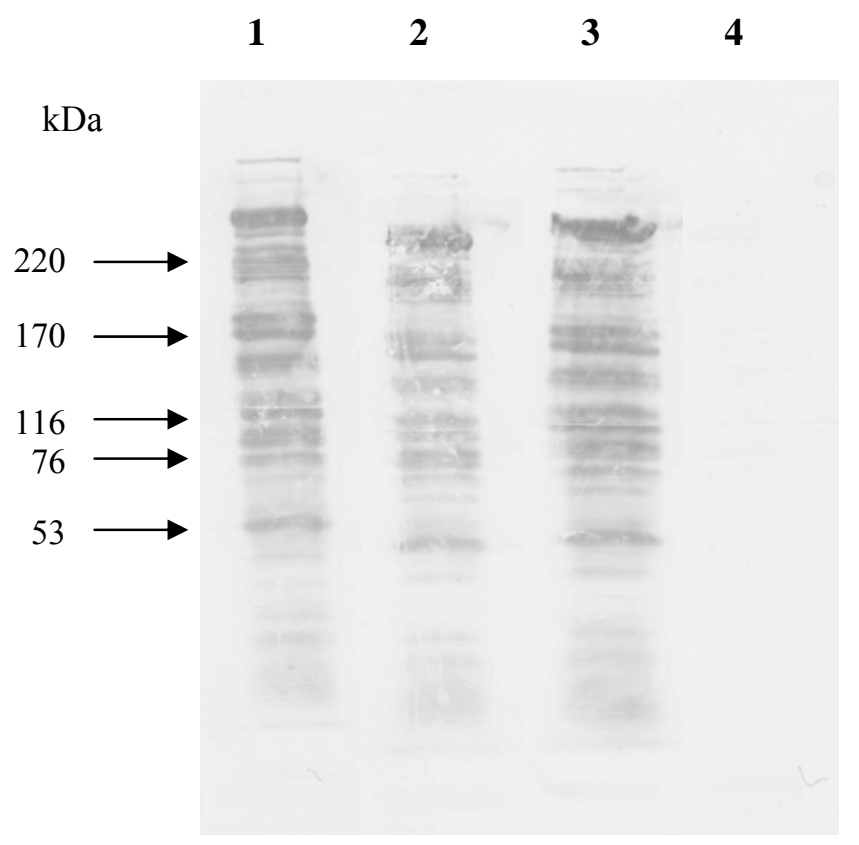

Figura 36 - Membrana de Immunoblotting. Gel de acrilamida em concentração de 7,5\% de acrilamida, coloração com Coomassie Blue 250 R. Toxina Tetânica tratada com 2-mercaptoetanol. Linha 1 - pool das amostras de soro dos cavalos do Grupo 1B; linha 2 - pool das amostras de soro dos cavalos do Grupo 2B; linha 3 - pool das amostras de soro dos cavalos do Grupo 3B; linha 4 - soro normal de cavalo.

Da análise dos resultados observa-se que os antisoros obtidos quando da imunização com toxina conjugada ou não ao mPEG-SPA, e na ausência de $\mathrm{Al}(\mathrm{OH})_{3}$, são capazes de reconhecer com mais intensidade um maior número de determinantes antigênicos [Figuras 33 e 34] do que aqueles com $\mathrm{Al}(\mathrm{OH})_{3}$ [Figuras 35 e 36]. Ademais, quando a toxina foi tratada com 2-mercaptoetanol os antisoros obtidos com antígenos formulados sem o gel de $\mathrm{Al}(\mathrm{OH})_{3}$ foram hábeis em reconhecer um maior número de determinantes antigênicos, incluindo bandas com massa molecular próximas a $53 \mathrm{kDa}$ e $116 \mathrm{kDa}$ que podem corresponder às cadeias leve e pesada da toxina tetânica [Figura 34].

Na Figura 33 (antígenos não adsorvidos), linhas 1 e 3, estão representadas as amostras com as maiores médias $(651 \mathrm{UI} / \mathrm{mL})$ de antitoxina tetânica [Tabela 24] e que, comparativamente, reconheceram praticamente o mesmo número de determinantes antigênicos, porém, com menor especificidade. Na Figura 35 (antígenos adsorvidos), nas linhas 1 e 3, onde a menor quantidade de determinantes antigênicos é reconhecida, estão representadas as amostras cujos valores médios de anticorpos foram $379 \mathrm{UI} / \mathrm{mL}$ e $434 \mathrm{UI} / \mathrm{mL}$ [Tabela 24], respectivamente, sendo os menores dentre as amostras analisadas na mesma figura. Além disso, verifica-se que o melhor reconhecimento de determinantes antigênicos ocorreu com a amostra da linha 3, cuja média de títulos foi de $536 \mathrm{UI} / \mathrm{mL}$. Ainda nessa figura, 
a visualização mais nítida de bandas com massa molecular em torno de 170 e $220 \mathrm{kDa}$ pode estar relacionada à produção de imunoglobulinas não específicas geradas pelo uso de $\mathrm{Al}(\mathrm{OH})_{3}$.

$\mathrm{Na}$ Figura 36 houve o reconhecimento de menor quantidade de determinantes antigênicos, mas de maior quantidade de bandas reveladas, evidenciando-se o possível reconhecimento de anticorpos específicos e não específicos, bem como de bandas com massa molecular próximas a $53 \mathrm{kDa}$ e $116 \mathrm{kDa}$ que podem corresponder às cadeias leve e pesada da toxina tetânica.

Saliente-se que o ensaio immunoblotting demonstrou que a conjugação da toxina tetânica ao mPEG-SPA 5.000 não apresentou efeito considerável sobre a resposta específica, mas pode ter colaborado com a produção de anticorpos não específicos induzidos pelo tratamento com o gel de hidróxido. Essa constatação confirma outros trabalhos realizados que evidenciaram a ausência ou baixa imunogenicidade do mPEG como sendo uma das principais características do polímero (KODERA et al., 1998; PASUT et al., 2007).

O ensaio de immunoblotting revelou que a imunização de cavalos com Toxina Tetânica Fluida resultou em resposta imune mais específica do que aquela realizada com a Toxina Tetânica adsorvida em gel de $\mathrm{Al}(\mathrm{OH})_{3}$. Essa constatação também confirma estudo anteriormente realizado no Instituto Butantan, no qual camundongos de linhagens geneticamente selecionadas segundo a alta ou baixa produção de anticorpos foram imunizados com anatoxina tetânica solúvel e anatoxina tetânica adsorvida pelo gel de $\mathrm{Al}(\mathrm{OH})_{3}$; nesse caso, os animais que receberam o antígeno solúvel também apresentaram títulos significativamente superiores àqueles imunizados com antígeno adsorvido (VANCETTO et al., 1992).

Embora tenha apresentado variações, o ensaio immunoblotting corroborou outros ensaios realizados no presente trabalho no que diz respeito ao melhor reconhecimento de frações antigênicas pelos soros dos cavalos imunizados que melhor responderam.

Em seu conjunto, esses resultados indicam que há correlação positiva entre os fenótipos qualitativos e quantitativos para tal imunógeno nesses animais, aspecto que, provavelmente, reproduz essas características face aos processos que condicionam a resistência dos indivíduos numa população natural. 


\section{CONCLUSÕES}

Os resultados obtidos permitem concluir que:

1) A metodologia para purificação da toxina tetânica conduziu a um resultado de pureza antigênica superior ao exigido pela WHO para a Anatoxina Tetânica [Produto Acabado a Granel] destinada às vacinas indicadas para uso humano, além de ser potencialmente escalonável em utilização industrial;

2) O tratamento da toxina tetânica pelo mPEG-SPA 5.000 ou pelo mPEG-SPA 20.000 inibiu a atividade neurotóxica da proteína fluida, bem como da toxina adsorvida ao gel de $\mathrm{Al}(\mathrm{OH})_{3}$, conforme demonstrado no ensaio Dose Letal 50\%;

3) A via de inoculação subcutânea foi mais efetiva na indução de resposta à toxina tratada pelo mPEG-SPA;

4) $\mathrm{O}$ melhor efeito adjuvante do gel de $\mathrm{Al}(\mathrm{OH})_{3}$ foi evidenciado pela aplicação das amostras por via intramuscular;

5) Os esquemas de imunizações permitiram diferenciar a atividade adjuvante dos antígenos empregados, demonstrando a superioridade da Toxina Tetânica Fluida;

6) $\mathrm{O}$ ensaio imunodifusão foi eficaz na avaliação da resposta imune;

7) O ToBI Teste foi suficiente para avaliar a evolução da resposta imune no decorrer das imunizações, evitando-se a realização de ensaios in vivo;

8) O immunoblotting indicou uma provável superioridade antigênica da Toxina Tetânica Fluida relativamente aos adjuvantes empregados, além de ter confirmado que o tratamento da toxina tetânica pelo mPEG-SPA 5.000 não apresentou efeito considerável sobre a resposta imune.

Na eventual continuidade do estudo de tratamento de toxinas bacterianas pelo mPEG, sugere-se verificar a capacidade do polímero em reduzir a toxicidade da toxina diftérica com o intuito de minimizar os graves efeitos locais provocados em eqüinos destinados à produção do soro antidiftérico para uso humano no Instituto Butantan. 


\section{REFERÊNCIAS}

ABUCHOWSKI, A.; KAZO, G. M.; VERHOEST, C. R. JR.; VAN ES, T.; KAFKEWITZ, D.; NUCCI, M. L.; VIAU, A. T.; DAVIS, F. F. Cancer therapy with chemically modified enzymes. I. Antitumor properties of polyethylene glycol-asparaginase conjugates. Cancer Biochem. Biophys., England, v. 7, p. 175-186, 1984.

ADAMS, E. B.; LAURENCE, D. R.; SMITH, J. W. G. In: Tetanus. Great Britain: Blackwell Scientific Publications, 1969. p. 1-5.

AGGERBECK, H.; HERON, I. Adjuvanticity of aluminium hydroxide and calcium phosphate in diphtheriae-tetanus vaccines-I. Vaccine, Netherlands, v. 13, n. 4, p. 1360-1365, 1995.

AHNERT-HILGER, G.; DAUZENROTH, M. E.; HABERMANN, E.; HENSCHEN, A.; KRIEGLSTEIN, K.; MAULER, F.; WELLER, U. Chains and fragments of tetanus toxin, and their contribution to toxicity. J. Physiol., Paris, v. 84, n. 3, p. 229-236, 1990.

ALVING, C. R. Design and selection of vaccine adjuvants: animal models and human trials. Vaccine, Netherlands, v. 20, p. S56-S64, 2002.

BAILON, P.; BERTHOLD, W. Polyethylene glycol-conjugated pharmaceutical proteins [reviews-research focus]. Pharm. Sci. Technol. Today, England, v. 1, n. 8, p. 352-356, 1998.

BERGEY, G. K.; MACDONALD, R. L.; HABIG, W. H.; HARDEGREE, M. C.; NELSON, P. G. Tetanus toxin: convulsant action on mouse spinal cord neurons in culture. J. Neurosci., U.S.A., v. 3, n. 11, p. 2310-2323, 1983.

BEUTLER, B. et al. Imunidade Inata. In: JANEWAY, J. R. et al. Imunobiologia: O Sistema Imune na Saúde e na Doença. 6. ed. Rio Grande do Sul: Artmed, 2007. Cap. 2, p. 37-101.

BIER, O. Bacilos Esporulados Gram-positivos. In:

São Paulo: Edições Melhoramentos, 1978a. p. 555-561.

. Bacteriologia e Imunologia. 19. ed.

De acordo com:

ASSOCIAÇÃO BRASILEIRA DE NORMAS TÉCNICAS. NBR 6023: Informação e documentação: referências: elaboração. Rio de Janeiro, 2002. 
BIER, O. Reações Sorológicas. In: Bacteriologia e Imunologia. 19. ed. São Paulo: Edições Melhoramentos, 1978b. p. 260-306.

BIER, O. Técnicas Imunológicas. In: Bacteriologia e Imunologia. 19. ed. São Paulo: Edições Melhoramentos, 1978c. p. 870-918.

BRADFORD, M. A rapid and sensitive method for the quantitation of microgram quantities of protein utilizing the principle of protein-dye binding. Anal. Biochem., U.S.A., v. 72, p. 248-254, 1976.

BRASIL. Portaria $n^{\circ} 175$, de 11 de novembro de 1996. Normas Técnicas de Fabricação e Controle de Qualidade das Vacinas: Tríplice Bacteriana, Toxóide Tetânico, Dupla Adulto, Dupla Infantil. Aprovada pela Vigilância Sanitária. Ministério da Saúde. Diário Oficial [da] República Federativa do Brasil, Brasília, DF, 12 nov. 1996. Seção 1, n 220, p. 2351223547.

BRASIL. Portaria n ${ }^{\circ}$ 551, de 13 de julho de 1998. Norma Nacional de Produção e Controle de Qualidade de Vacina Tríplice (DTP). Diário Oficial [da] república Federativa do Brasil, Brasília, DF, 14 jul. 1998. Seção 1, n 132-E, p. 6-13.

BROWN, F. Formaldehyde as an inactivant [letter]. Vaccine, Netherlands, v. 13, n. 2, p. 231, 1995.

BRÜGGEMANN, H.; BÄUMER, S.; FRICKE, W. F.; WIEZER, A.; LIESEGANG, H.; DECKER, I.; HERZBERG C.; MARTINEZ-ARIAS, R.; MERKL, R.; HENNE, A.; GOTTSCHALK, G. The genome sequence of Clostridium tetani, the causative agent of tetanus disease. Proc. Natl. Acad. Sci. U.S.A., U.S.A., v. 100, n. 3, p. 1316-1321, 2003.

BRÜGGEMANN, H.; GOTTSCHALK, G. Insights in metabolism and toxin production from the complete genome sequence of Clostridium tetani. Anaerobe, England, v. 10, p. 53-68, 2004.

BULLOCK, J.; CHOWDHURY, S.; SEVERDIA, A.; SWEENEY, J.; JOHNSTON, D.; PACHLA, L. Comparison of results of various methods used to determine the extent of modification of methoxy polyethylene glycol 5.000-modified bovine cupric-zinc superoxide dismutase. Anal. Biochem., U.S.A., v. 254, p. 254-262, 1997.

BUTLER, N. R. VOYCE, M. A.; BURLAND, W. L.; HILTON, M. L. Advantages of aluminium hydroxide adsorbed combined diphtheria, tetanus, and pertussis vaccines for the immunization of infants. Br. Med. J., England, v, 1, p. 663-6, 1969. 
CALICETI, P.; VERONESE, F. M.; JONAK, Z. Immunogenic and tolerogenic properties of monomethoxypoly(ethylene glycol) conjugated proteins. Farmaco, France, v. 54, p. 430-437, 1999.

CALICETI, P.; VERONESE, F. M. Pharmacokinetic and biodistribution properties of poly (ethylene glycol)-protein conjugates. Adv. Drug. Deliv. Rev., Netherlands, v. 55, p. 12611277, 2003.

CANTER, H. M.; SILVA, A. V. da. 100 anos de Butantan. São Paulo: Gabarito de Marketing Editorial, 2000. 73 p.

CARDOSO, D. F.; YAMAGUCHI, I. K.; MOURA DA SILVA, A. M. Produção de Soros Antitoxinas e Perspectivas de Modernização por Técnicas de Biologia Molecular. In: CARDOSO, J. L. C. et al. Animais Peçonhentos no Brasil: Biologia, Clínica e Terapêutica dos Acidentes. São Paulo: Sarvier Editora de Livros Médicos, 2002. Cap. 36, p. 367-379.

CARVALHO, C. A. R. Tétano. Disponível em: $<$ http://www.fmt.am.gov.br/manual/tetano.htm>. Acesso em: 11 dez. 2007.

CHEN, Y.; TAKATA, M.; MAITI, P. K.; MOHAPATRA, S.; MOHAPATRA, S. S.; SEHON, A. H. The suppressor factor of $\mathrm{T}$ suppressor cells induced by tolerogenic conjugates of ovalbumin and monomethoxypolyethylene glycol is serologically and physicochemically related to the alpha beta heterodimer of the T cell receptor. J. Immunol., U.S.A., v.152, n. 1: p. 3-11, 1994.

COFFMAN, B. et al. Alergia e Hipersensibilidade. In: JANEWAY, J R et al. Imunobiologia: O Sistema Imune na Saúde e na Doença. 6. ed. Rio Grande do Sul: Artmed, 2007. Cap. 12, p. 517-556.

CONNEL, G. E.; PAINTER, R. H. Fragmentation of immunoglobulin during storage. Can. J. Biochem., Canada, v. 44, p. 371-379, 1966.

COX, J. C.; COULTER, A. R. Adjuvants-a classification and review of their modes of action. Vaccine, Netherlands, v. 15, p. 248-256, 1997.

CRAVEN, C. J.; DAWSON, D. J. The chain composition of tetanus toxin. Biochim. Biophys. Acta, Netherlands, v. 317, p. 277-285, 1973. 
DIAS DA SILVA, W. Imunidade às Infecções. In: BIER, O. G.; MOTA, I.; DIAS DA SILVA, W. Imunologia Básica e Aplicada. 4 ed. Rio de Janeiro: Editora Guanabara Koogan, 1989. Cap. 17, p. 424-486.

DRIGALSKI, W. V.; LOT, F. In: O Homem Contra os Micróbios. Minas Gerais: Editora Itatiaia, 1959. $278 \mathrm{p}$.

DUNCAN, R.; SPREAFICO, F. Polymer conjugates. Pharmacokinetic considerations for design and development. Clin. Pharmacokinet., New Zealand, v. 27, p. 290-306, 1994.

EDELMAN, R.; TACKETT, C. O. Adjuvants. Int. Rev. Immunol., U.S.A., v. 7, p. 51-66, 1990.

EHRETH, J. The global value of vaccination. Vaccine, Netherlands, v. 21, p. 667-670, 2003.

EISEL, U.; JARAUSCH, W.; GORETZKI, K.; HENSCHEN, A.; ENGELS, J.; WELLER, U.; HUDEL, M.; HABERMANN, E.; NIEMANN, H. EMBO J., England, v. 5, n. 10, p. 24952502, 1986.

ELLOUZ, F.; ADAM, A.; CIORBARU, R.; LEDERER, E. Minimal structural requirements for adjuvant activity of bacterial peptidoglycan derivatives. Biochem. Biophys. Res. Commun., U.S.A., v. 59, n. 4, p. 1317-1325, 1974.

EUROPEAN PHARMACOPEIA 5.0. Assays. 5. ed. Council of Europe, n. 10, p. 131. Strasbourg, 2005. v. 1.( European Treaty Series, 50).

FAIRWEATHER, N. F.; LYNESS, V. A. The complete nucleotide sequence of tetanus toxin. Nucleic Acids Res., England, v. 14, p. 7809-7812, 1986.

FERRI, R. G.; CALICH, V. L. G.; VAZ, C. A. Interação Antígeno-Anticorpo in vitro. In: __. Imunologia. 2. ed. São Paulo: Artes Médicas, 1979. Cap. 3, p. 54-116.

FIKRIG, E. et al. Manipulação da Resposta Imune. In: JANEWAY, J R et al. Imunobiologia: O Sistema Imune na Saúde e na Doença. 6. ed. Rio Grande do Sul: Artmed, 2007. Cap., 14. p. 613-663.

FINEGOLD, S. M. In: Anaerobic Bacteria in Human Disease. England: Academic Press, 1977. 710p. 
FINN, C. W.; SILVER, R. P.; HABIG, W. H.; HARDEGREE, M. C. The structural gene for tetanus toxin is on a plasmid. Science, U.S.A., v. 224, p. 881-884, 1984.

FOTINOU, C.; EMSLEY, P.; BLACK, I.; ANDO, H.; ISHIDA, H.; KISO, M.; SINHA, K. A.; FAIRWEATHER, N. F.; ISAACS, N. W. The crystal structure of tetanus toxin HC fragment complexed with a synthetic GT1b analogue suggests cross-linking between ganglioside receptors and the toxin. J. Biol. Chem., U.S.A., v. 276, n. 34, p. 32274-32281, 2001.

FRATELLI, F.; PRADO, S. M. A.; VANCETTO, M. D. C.; OLIVEIRA, J. M. de; HIGASHI, H. G. Toxina tetânica: produção e purificação em escala industrial. Arq. Biol. Tecnol., v. 36, p. 709-719, 1993.

FUNASA. Ministério da Saúde. Vigilância Epidemiológica. Situação da prevenção e controle das doenças transmissíveis no Brasil. Brasília, set. 2002. Disponível em: $<$ http://bvsms.saude.gov.br/bvs/publicacoes/funasa/situacao_doencas.pdf $>$. Acesso em: 09 jan. 2008.

FUNDO INTERNACIONAL DE FINANÇAS PARA IMUNIZAÇÃO. Disease information: tetanus. Available from: $\quad<$ http://www.gavistg3.elcaservices.com/General_Information/Immunization_informa?Diseas...>. Acesso em: $26 \mathrm{dez}$. 2007.

GIUDICE, G. D.; PODDA, A.; RAPPUOLI, R. What are the limits of adjuvanticity? Vaccine, Netherlands, v. 20, S38-S41, 2002.

GOONETILlEKE, A.; HARRIS, J. B. Clostridial neurotoxins. J. Neurol. Neurosurg. Psychiatr., England, v. 75, p. iii35-iii39, 2004. Suppl III.

GUIDOLIN, R.; CARICATI, C. P.; PRADO, S. M. A.; VANCETTO, M. D. C.; FRATELLI, F.; NISHIKAWA, A. K.; HIGASHI, H. G. Produção de plasma antitetânico hiperimune, de origem eqüina. Bol. Biotecnol., v. 3, p.17-23, 1992.

GUILHEN, F. B. Análise dos perfis de proteínas nas diversas etapas de produção e purificação das anatoxinas tetânica e diftérica: padronização de controles de qualidade internos. 117 f. Dissertação (Mestrado em Biotecnologia) - Programa de Pós-Graduação em Biotecnologia USP/Instituto Butantan/IPT, São Paulo, 2005.

GUIMARÃES, T. C. Tétano: ainda um problema de saúde pública. BEPA, n. 13, p. 1-17, 2005. Disponível em: <http://www.cve.saude.sp.gov.br/agencia/bepa13_tetano.htm>. Acesso em: 11 dez. 2007. 
GUPTA, R. K.; RELYVELD, E. H.; LINDBLAD, E. B.; BIZZINI, B.; BEN-EFRAIM, S.; GUPTA, C. K. Adjuvants - a balance between toxicity and adjuvanticity. Vaccine, Netherlands, v. 11, n. 3, p. 293-306, 1993.

GUPTA, R. K.; SIBER, G. R. Comparison of adjuvants activities of aluminium phosphate, calcium phosphate and stearyl tyrosine for tetanus toxoid. Biologicals, England, v. 22, p. 5363, 1994.

HABEEB, A. F. S. A. Determination of free amino groups in proteins by trinitrobenzenesulfonic acid. Anal. Biochem., U.S.A., v. 14, p. 328-336, 1966.

HELTING, T. B.; ZWISLER, O. Structure of tetanus toxin. I. Breakdown of the toxin molecule and discrimination between polypeptide fragments. J. Biol. Chem., U.S.A., v. 252, n. 1, p. 187-193, 1977.

HELTING, T. B.; PARSCHAT, S.; ENGELHARDT, H. Structure of tetanus toxin. Demonstration and separation of a specific enzyme converting intracellular tetanus toxin to the extracellular form. J. Biol. Chem., U.S.A., v. 254, n. 21, p. 10728-10733, 1979.

HENDRIKSEN, C. F.; vd GUN, J. W.; NAGEL, J.; KREEFTENBERG, J. G. The toxin binding inhibition test as a reliable in vitro alternative to the toxin neutralization test in mice for the estimation of tetanus antitoxin in human sera. J. Biol. Stand., England, v. 16, p. 287297, 1988.

HISTORIQUE.NET. Clostridium tetani (tetanus). Available from: $<$ http://microbes.historique.net/tetani.html>. Acesso em: $26 \mathrm{dez} .2007$.

HUMEAU, Y.; DOUSSAU, F.; GRANT, N. J.; POULAIN, B. How botulinum and tetanus neurotoxins block neurotransmitter release. Biochimie, Paris, v. 82, p. 427-446, 2000.

INADA, Y.; YOSHIMOTO, T.; MATSUSHIMA, A.; SAITO, Y. Engineering physicochemical and biological properties of proteins by chemical modification. Trends Biotechnol., England, v. 4, n. 3, p. 68-73, 1986.

INADA, Y.; FURUKAWA, M.; SASAKI, H.; KODERA, Y.; HIROTO, M.; NISHIMURA, H.; MATSUSHIMA, A. Biomedical and biotechnological applications of PEG-and PMmodified proteins [focus]. Trends Biotechnol., England, v. 13, p. 86-91, 1995.

INTERNATIONAL FINANCE FACILITY FOR IMMUNISATION. Available from: $<$ http://www.iff-immunisation.org/03_immunisation.html>. Acesso em: 26 dez. 2007. 
JANEWAY, JR. et al. Apêndice I. In: Imunobiologia: O Sistema Imune na Saúde e na Doença. 6. ed. Rio Grande do Sul: Artmed, 2007. p. 683-729.

JEFFERSON, T.; RUDIN, M.; PIETRANTONJ, C. D. Adverse events after immunization with aluminium-containing DTP vaccines: systematic review of the evidence [review]. Lancet Infect. Dis., U.S.A., v. 4, p. 84-90, 2004.

JONES, R. G. A.; LANDON, J. Enhanced pepsin digestion: a novel process for purifying antibody $\mathrm{F}(\mathrm{ab})_{2}$ fragments in high yield from serum. J. Immunol. Methods, Netherlands, v. 263, p. 57-74, 2002.

KADIS, S.; MONTIE, T. C.; AJL, S. J. In: Microbial Toxins. England: Academic Press, 1971, v. IIA, p. 69-70.

KNAPP, M.; SEGEIKE, B.; RUPP, B. The 1.61 angstron structure of the tetanus toxin ganglioside binding region: solved by MAD mir phase combination. In: Annual Meeting of the Am. Cryst. Assoc, 1998. Abstracts Papers, 1998. v. 25, p. 90.

KODERA, Y.; TANAKA, H.; MATSUSHIMA, A.; INADA, Y. Chemical modification of L-asparaginase with a comb-shaped copolymer of polyethylene glycol derivative and maleic anhydride. Biochem. Biophys. Res. Commun., U.S.A., v. 184, n. 1, p. 144-148, 1992.

KODERA, Y.; MATSUSHIMA, A.; HIROTO, M.; NISHIMURA, H.; ISHII, A.; UENO, T.; INADA, Y. Pegylation of proteins and bioactive substances for medical and technical applications. Prog. Polym. Sci., England, v. 23, p. 1233-1271, 1998.

KOIDE, A.; SUZUKI, S.; KOBAYASHI, S. Preparation of polyethylene glycol-modified streptokinase with disappearance of binding ability towards anti-serum and retention of activity. FEBS Lett., Netherlands, v. 143, n. 1, p. 73-6, 1982.

KOZLOWSKI, A.; HARRIS, J. M. Improvements in protein PEGylation: pegylated interferons for treatment of hepatitis C. J. Control Release, Netherlands v. 72, p. 217-224, 2001.

LAEMMLI, U. K. Cleavage of structural proteins during the assembly of the head of bacteriophage T4. Nature, England, v. 227, p. 680-685, 1970.

LALLI, G.; BOHNERT, S.; DEINHARDT, K.; VERASTEGUI, C.; SCHIAVO, G. The journey of tetanus and botulinum neurotoxins in neurons. Trends Microbiol., England, v. 11, n. 9, p. 431-437, 2003. 
LATHAM, W. C.; BENT, B F.; LEVINE, L. Tetanus toxin production in the absence of protein. Appl. Microbiol., U.S.A., v. 10, p. 146-152, 1962.

LINDBLAD, E. B. Aluminium compounds for use in vaccines [special feature]. Immunol. Cell Biol., Australia, v. 82, p. 497-505, 2004.

LYNG, G.; BENTZON, M. W. The quantitative estimation of diphtheria and tetanus toxoids: 1- The flocculation test and Lf-unit. J. Biol. Stand., England, v. 15, p. 27-37, 1987.

MALLICK, I. H.; WINSLET, M. C. A review of the epidemiology, pathogenesis and management of tetanus. Int. J. Surg., England, v. 2, n. 2, p. 109-112, 2004.

MARCIANI, D. J. Vaccine adjuvants: role and mechanisms of action in vaccine immunogenicity [reviews]. Drug Discov. Today, England, v. 8, n. 20, p. 934-943, 2003.

MATSUDA, M.; YONEDA, M. Dissociation of tetanus neurotoxin into two polypeptide fragments. Biochem. Biophys. Res. Commun., U.S.A., v. 57, n. 4, p. 1257-1262, 1974.

MATSUDA, M.; YONEDA, M. Isolation and purification of two antigenically active, "complementary" polypeptide fragments of tetanus neurotoxin. Infect. Immun., U.S.A., v. 12, n. 5, p. 1147-1153, 1975.

MATSUDA, M.; YONEDA, M. Reconstitution of tetanus neurotoxin from, two antigenically active polypetide fragments. Biochem. Biophys. Res. Commun., U.S.A., v. 68, n. 3, p. 668-674, 1976.

MATSUSHIMA, A.; KODERA, Y.; HIROTO, M.; NISHIMURA, H.; INADA, Y. Bioconjugates of proteins and polyethylene glycol: potent tools in biotechnological processes [review]. J. Mol. Catal. B. Enzym., Netherlands, v. 2, p. 1-17, 1996.

McKEE, A. S.; MUNKS, M. W.; MARRACK, P. How do adjuvants work? Important considerations for new generation adjuvants [commentary]. Immunity, U.S.A., v. 27, p. 687690, 2007.

MINISTÉRIO DA SAÚDE. BRASIL. Imunizações. O Programa Nacional de Imunizações. Disponível em: < http://portal.saude.gov.br/saude/>. Acesso em: 06 fev. 2008.

MONTECUCCO, C.; SCHIAVO, G. Structure and function of tetanus and botulinum neurotoxins. Q. Rev. Biophys, England, v. 28, n. 4, p. 423-472, 1995. 
MONTECUCCO, C.; ROSSETO, O.; SCHIAVO, G. Presynaptic receptor arrays for clostridial neurotoxins. Trends Microbiol., England, v. 12, p. 442-446, 2004.

MONTEIRO, J. L. Immunisação anti-tetanica pelo methodo toxoide-toxina. Mem. Inst. Butantan, Brazil, v. 2, p. 85-94, 1925.

MORAES, E. N.; PEDROSO, E. R. P. Tétano no Brasil: doença do idoso? Rev. Soc. Bras. Med. Trop., Brazil, v. 33, n. 3, p. 271-275, 2000.

MORAES-PINTO, M. I.; ORUAMABO, R. S.; IGBAGIRI, F. P.; CHAN, M. C. K.; PRADO, S. M. A.; VANCETTO, M. D. C.; JOHNSON, P. M.; HART, C. A. Neonatal tetanus despite immunization and protective antitoxin antibody [correspondence]. J. Infect. Dis., U.S.A., v. 171, p. 1076-1077, 1995.

MOTA, I. Antígenos. In: BIER, O. G.; MOTA, I. DIAS DA SILVA, W. Imunologia Básica e Aplicada. 4 ed. Rio de Janeiro: Editora Guanabara Koogan, 1989. Cap. 5. p. 85-97.

MURRAY, P. R.; ROSENTHAL, K. S.; KOBAYASHI, G. S.; PFALLER, M. A. Clostridium. In: . Microbiologia Médica. 30. ed. Rio de Janeiro. Editora Guanabara Koogan, 2000. p. $\overline{246-255 .}$

NA, D. H.; PARK, E. J.; JO, Y. W.; LEE, K. C. Capillary electrophoretic separation of highmolecular-weight poly(ethylene glycol)-modified proteins. Anal. Biochem., U.S.A., v. 373, p. 207-212, 2008.

NAGASAKI, Y.; KUTSUNA, T.; IIJIMA, M.; KATO, M.; KATAOKA, K.; KITANO, S.; KADOMA, Y. Formyl-ended heterobifunctional poly(ethylene oxide): synthesis of poly(ethylene oxide) with a formyl group at one end and a hydroxyl group at the other end. Bioconjug. Chem., U.S.A., v. 6, n. 2, p. 231-233, 1995.

NEVILLE, D. M. Jr. Molecular weight determination of protein-dodecyl sulfate complexes by gel electrophoresis in a discontinuous buffer system. J. Biol. Chem., U.S.A., v. 246, p. 63286334, 1971.

NISHIKAWA, A. K.; PRADO, S. M. A.; VANCETTO, M. D. C.; STEPHANO, M. A.; HIGASHI, H. G. Estimation of anti-tetanus toxin antibody in equine sera by enzyme immunoassay. Arq. Biol. Tecnol., Brazil, v. 38, n. 2, p. 465-475, 1995. 
O’ HAGAN, D. T.; OTT, G. S.; NEST, V. G. Recent advances in vaccine adjuvants: the development of MF59 emulsion and polymeric microparticles [reviews]. Mol. Med. Today, England, v. 3, p. 69-75, 1997.

O' HAGAN, D. T.; MacKICHAN, M. L.; MANMOHAN, S. Recent developments in adjuvants for vaccines against infectious diseases [review]. Biomol. Eng., Netherlands, v. 18, p. 69-85, 2001.

O' HAGAN, D. T.; RAPPUOLI, R. Novel approaches to pediatric vaccine delivery. Adv. Drug Deliv. Rev., Netherlands, v. 58, p. 29-51, 2006.

PASUT, G.; CABOI, F.; SCHREPFER, R.; TONON, G.; SCHIAVON, O.; VERONESE, F. M. New active poly(ethylene glycol) derivative for amino coupling. Reactive Polymers, Netherlands, v. 67, p. 529-539, 2007.

PASUT, G.; VERONESE, F. M. Polymer-drug conjugation, recent achievements and general strategies. Prog. Polym. Sci., England, v. 32, p. 933-961, 2007.

PETROVSKY, N.; AGUILAR, J. C. Vacccine adjuvants: current state and future trends [special feature]. Immunol. Cell Biol., Australia, v. 82, p. 488-496, 2004.

PRADO, S. M. A.; VANCETTO, M. D. C.; FRATELLI, F.; PRAL, M. M.; OLIVEIRA, J. M. de; HIGASHI, H. G. Purificação industrial do toxóide tetânico por gel filtração. Bol. Biotecnol., Brazil, v. 3, p.11-16, 1992.

PRADO, S. M. A.; VANCETTO, M. D. C.; OLIVEIRA, J. M. de; FRATELli, F.; MATHIAS, S.J.D.; HIGASHI, H. G. Otimização do processo de purificação industrial de toxóide tetânico por gel filtração. Bol. Biotecnol., Brazil, v. 4, p.3-8, 1993.

PRADO, S. M. A.; VANCETTO, M. D. C.; OLIVEIRA, J. M. de; FRATELLI, F.; HIGASHI, H. G. Development and validation study for the chromatographic purification process for tetanus anatoxin on Sephacryl S-200 high resolution. Boll. Chim. Farm., Italy, v. 138, p. 364-368, 1999.

QAZI, O.; BOLGIANO, B.; CRANE, D.; SVERGUN, D. I.; KONAREV, P. V.; YAO, Z. P.; ROBINSON, C. V.; BROWN, K. A.; FAIRWEATHER, N. The $\mathrm{H}_{\mathrm{C}}$ fragment of tetanus toxin forms stable, concentration-dependent dimmers via an intermolecular disulphide bond. J. Mol. Biol., England, v. 365, p. 123-134, 2007. 
RAPPUOLI, R. Toxin inactivation and antigen stabilization: two different uses of formaldehyde [short review]. Vaccine, Netherlands, v. 12, n. 7, p. 579-581, 1994.

RAPPUOLI, R. New and Improved Vaccines Against Diphtheria and Tetanus. In: LEVINE, M. M.; WOODROW, G. C.; COBON, G. S. New Generation Vaccines. New York: Marcel Dekker, 1997. p. 417-436.

RESEARCH COLLABORATORY FOR STRUCTURAL BIOINFORMATICS. RCSB. Protein Data Bank. Available from: $<$ http://www.rcsb.org/pdb/home/home.do $>$. Acesso em: 12 dez. 2007.

REDE INTEGRADA DE INFORMAÇÕES PARA A SAÚDE. Indicador: D. 1.5 Incidência de demais tipos de tétano. Disponível em: $<$ http://www.ripsa.org.br/fichasIDB/pdf/ficha_D.1.15pdf $>$. Acesso em: 12 dez. 2007a.

REDE INTEGRADA DE INFORMAÇÕES PARA A SAÚDE. Indicador: D. 1.4 Incidência de tétano neonatal. Disponível em: $<$ http://www.ripsa.org.br/fichasIDB/record.phd?NODE=d.1.4elang=pt $>$. Acesso em: $12 \mathrm{dez}$. $2007 \mathrm{~b}$.

ROBERTS, M. J.; BENTLEY, M. D.; HARRIS, J. M. Chemistry for peptide and protein PEGylation. Adv. Drug Deliv. Ver., Netherlands, v. 54, p. 459-476, 2002.

ROPER, M. H.; VANDELAER, J. H.; GASSE, F. L. Maternal and neonatal tetanus [seminar]. Lancet, England, v. 370, p. 1947-1959, 2007.

SANTA-ROSA, C. A. Imunoprofilaxia. In: FERRI, R. G.; CALICH, V. L. G.; VAZ, C. A. Imunologia. 2. ed. São Paulo: Artes Médicas, 1979. Cap. 8, p. 221-226.

SÃO PAULO. Secretaria de Estado da Saúde. Centro de Vigilância Epidemiológica. Programa Estadual de Imunização. Disponível em: $<$ http://www.cve.saude.sp.gov.br/htm/cve.pni.htm/Cve.pni.htm>. Acesso em: 29 abr. 2004.

SCHELLEKENS, H. Immunogenicity of therapeutic proteins: clinical implications and future prospects. Clin. Ther., U.S.A., v. 24, n. 11, p. 1720-40, 2002.

SCHIAVO, G.; POULAIN, B.; ROSSETTO, O.; BENFENATI, F.; TAUC, L.; MONTECUCCO, C. Tetanus toxin is a zinc protein and its inhibition of neurotransmitter release and protease activity depend on zinc. EMBO J., England, v. 11, n. 10, p. 3577-3583, 1992a. 
SCHIAVO, G.; BENFENATI, F.; POULAIN, B.; ROSSETTO, O.; DE LAURETO, P.; DasGUPTA, B. R.; MONTECUCCO, C. Tetanus and botulinum-B neurotoxins block neurotransmitter release by proteolytic cleavage of synaptobrevin. Nature, England, v. 359, p. 832-835, $1992 b$.

SCHIAVO, G.; MATTEOLI, M.; MONTECUCCO, C. Neurotoxins affecting neuroexocytosis. Physiol. Rev., U.S.A., v. 80, n. 2, p.717-766, 2000.

SCHIJNS, V. E. J. C. Immunological concepts of vaccine adjuvant activity [commentary]. Curr. Opin. Immunol., England, v. 12, p. 456-463, 2000.

SCHRAMM, J. M. A.; SANCHES, O.; SZWARCWALD, C. L. Análise da mortalidade por tétano neonatal no Brasil (1979-1987). Cad. Saúde Públ. Rio de Janeiro, Brazil, v. 12, n. 2, p. 217-224, 1996.

SCHWAB, M. E.; SUDA, K.; THOENEN, H. Selective retrograde transsynaptic transfer of a protein, tetanus toxin, subsequent to its retrograde axonal transport. J. Cell Biol., U.S.A., $\quad$ v. 82, p. 798-810, 1979.

SIMONSEN, O. Vaccination against tetanus and diphtheria. Dan. Med. Bull., Denmark, v. 36, p. 24-47, 1989.

SINGH, M.; UGOZZOLI, M.; KAZZAZ, J.; CHESKO, J.; SOENAWAN, E.; MANNUCCI, D.; TITTA, F.; CONTORNI, M.; VOLPINI, G.; GUIDICE, G. D.; O’HAGAN, D. T. A preliminary evaluation of alternative adjuvants to alum using a range of established and new generation vaccine antigens. Vaccine, Netherlands, v. 24, p. 1680-1686, 2006.

SO, T.; ITO, H.; TSUJIHATA, Y.; HIRATA, M.; UEDA, T.; IMOTO, T. The molecular weight ratio of monometoxypolyethylene glycol (mPEG) to protein determines the immunotolerogenicity of mPEG proteins. Protein Eng., England, v. 12, n. 8, p. 701-705, 1999.

SOARES, A. L.; GUIMARÃES, G. M.; POLAKIEWICZ, B.; PITOMBO, R. N. M.; ABRAHÃO-NETO, J. Effects of polyethylene glycol attachment on physicochemical and biological stability of E. coli L-asparaginase. Int. J. Pharm., Netherlands, v. 237, p. 163-170, 2002.

SONOBE, M. H.; TREZENA, A. G.; GUILHEN, F. B.; TAKANO, V. L.; FRATELLI, F.; SAKAUCHI, D.; MORAIS, J. F.; PRADO, S. M. A.; HIGASHI, H. G. Determination of low tetanus or diphtheria antitoxin titers in sera by a toxin neutralization assay and a modified toxin-binding inhibiton test. Braz. J. Med. Biol. Res., v. 40, p. 69-76, 2007. 
STEPHANO, M. A. Veneno de Bothrops jararaca modificado com mPEG (monometoxipolietileno glycol) para elaboração de um adjuvante complexado à partícula antigênica. 100 f. Tese (Doutorado em Tecnologia Bioquímico-Farmacêutica) - Faculdade de Ciências Farmacêuticas, Universidade de São Paulo, São Paulo, 2005.

SUZUKI, T.; KANBARA, N.; TOMONO, T.; HAYASHI, N.; SHINOHARA, I. Physicochemical and biological properties of poly(ethylene glycol)-coupled immunoglobulin G. Biochim. Biophys. Acta, Netherlands, v.788, n. 2, p.248-55, 1984.

SUZUKI, T.; IKEDA, K.; TOMONO, T. Physicochemical and biological properties of poly(ethylene glycol)-coupled immunoglobulin G. Part II. Effect of molecular weight of poly(ethylene glycol). J. Biomater. Sci. Polym. Ed., Netherlands, v.1, n. 2, p. 71-84, 1989.

TAVARES, W. Contaminação do solo do estado do Rio de Janeiro pelo Clostridium tetani: Contribuição ao conhecimento da distribuição natural do bacilo tetânico. $179 \mathrm{f}$. Tese (Doutorado em Doenças Infecciosas e Parasitárias) - Faculdade de Medicina, Universidade Federal do Rio de Janeiro, Rio de Janeiro, 1975.

THWAITES, C. L. Tetanus. Curr. Anaesth. Crit. Care, Scotland, v. 16, p. 50-57, 2005.

TSAI, N.; CHENG, T.; ROFFLER, S. R. Sensitive measurement of polyethylene glycolmodified proteins. Biotechniques, England, v. 30, p. 396-402, 2001.

TURTON, K.; CHADDOCK, J. A.; ACHARYA, K. R. Botulinum and tetanus neurotoxins: structure, function and therapeutic utility [review]. Trends Biochem. Sci., England, v. 27, n. 11, p. 552-558, 2002.

VALLEE, R. B.; BLOOM, G. S. Mechanisms of fast and slow axonal transport. Annu. Rev. Neurosci., U.S.A., v. 14, p. 59-92, 1991.

VANCETTO, M. D. C.; PRADO, S. M. A.; HIGASHI, H. G.; NISHIKAWA, A. K.; SANT' ANNA, O. A. Estudo da proteção de anticorpos anti-toxina tetânica em diferentes linhagens de camundongos. In: REUNIÃO ANUAL DA FEDERAÇÃO DE SOCIEDADES DE BIOLOGIA EXPERIMENTAL, 7., 1992, Caxambu, 1992, M.G. Resumos, Caxambu, 1992. p. 342 , res. 24.7 .

VANCETTO, M. D. C.; PRADO, S. M. A.; FRATELLI, F.; OLIVEIRA, J. M. de; HIGASHI, H. G. Tetanus toxoid purification: a case study. Nat. Biotechnol., U.S.A., v. 15, p. 807-808, 1997. 
VERONESE, F. M. Peptide and protein PEGylation: a review of problems and solutions [review]. Biomaterials, England, v. 22, p. 405-417, 2001.

VERONESE, F. M.; PASUT, G. PEGylation, successful approach to drug delivery [review]. Drug Discov. Today, England, v. 10, n. 21, p. 1451-1458, 2005.

WAGNER, B. Immunoglobulins and immunoglobulin genes of the horse. Dev. Comp. Immunol., U.S.A., v. 30, p. 155-164, 2006.

WESTERMEIER, R. Blotting. In: Electrophoresis in Practice. 2. ed. Weinheim. VCH, 1997. p. 59-70.

WORLD HEALTH ORGANIZATION. Manual for the production and control of vaccines: tetanus toxoids. Geneva: WHO, 1977. BLG/UNDP/77.2. Rev. 1.

WORLD HEALTH ORGANIZATION. Manual of details of tests required on final vaccines used in the WHO Expanded Programme of Immunization. Geneva: WHO, 1982. BLG/UNDP/82.1. Rev. 1.

WORLD HEALTH ORGANIZATION. Immunization, vaccines and biologicals. Neonatal tetanus. Available from: $<$ http://www.who.int/vaccines/en/neotetanus.shtml $>$. Acesso em: 26 dez. 2007.

YAMASAKI, N.; MATSUO, A.; ISOBE, H. Novel polyethylene glycol derivatives for modification of proteins. Agric. Biol. Chem., Japan, v. 52, n. 8, p. 2125-2127, 1988.

YU, T.; TRAINA, J. A.; PUNGOR, E. JR.; McCAMAN, M. Precise and comparative pegylation analysis by microfluidics and mass spectrometry. Anal. Biochem., U.S.A., v. 359, p. 54-62, 2006.

ZALIPSKY, S.; SELTZER, R.; MENON-RUDOLPH, S. Evaluation of a new reagent for covalent attachment of polyethylene glycol to proteins. Biotechnol. Appl. Biochem., England, v. 15 , p. 100-114, 1992.

ZHENG, C. Y.; MA, G.; SU, Z. Native PAGE eliminates the problem of PEG-SDS interaction in SDS-PAGE and provides an alternative to HPLC in characterization of protein PEGylation [research article]. Electrophoresis, Germany, v. 28, p. 2801-2807, 2007. 